BEATRIZ FERRAZ SCIGLIANO

ESTUDO DO EQUILÍBRIO BIOGEOQUÍMICO DAS FORMAS DE FÓSFORO CONSIDERANDO SUA DISTRIBUIÇÃO, PARTIÇÃO E COMPORTAMENTO AO LONGO DO COMPLEXO ESTUARINO-LAGUNAR DE CANANEIA-IGUAPE (SP) COMO FERRAMENTA PARA INDICAÇÃO DE IMPACTO AMBIENTAL

\footnotetext{
Dissertação apresentada ao Instituto Oceanográfico da Universidade de São Paulo, como parte dos requisitos para obtenção do título de Mestre em Ciências, área de Oceanografia Química.

Orientadora: Prof ${ }^{a}$. Dr ${ }^{\mathrm{a}}$ Elisabete de Santis Braga da Graça Saraiva
} 
Universidade de São Paulo

Instituto Oceanográfico

\section{ESTUDO DO EQUILÍBRIO BIOGEOQUÍMICO DAS FORMAS DE FÓSFORO CONSIDERANDO SUA DISTRIBUIÇÃO, PARTIÇÃO E COMPORTAMENTO AO LONGO DO COMPLEXO ESTUARINO-LAGUNAR DE CANANEIA-IGUAPE (SP) COMO FERRAMENTA PARA INDICAÇÃO DE IMPACTO AMBIENTAL}

\section{Beatriz Ferraz Scigliano}

Dissertação apresentada ao Instituto Oceanográfico da Universidade de São Paulo, como parte dos requisitos para obtenção do título de Mestre em Ciências, área de Oceanografia Química.

\section{Versão Corrigida}

Julgada em 03/08/2016

Prof(a). Dr(a). Elisabete de Santis Braga

Conceito

Prof(a). Dr(a). Cristina Freire Nordi

Conceito

Prof(a). Dr(a). Joel Barbujiani Sigolo

Conceito 


\section{Sumário}

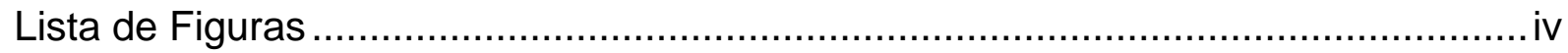

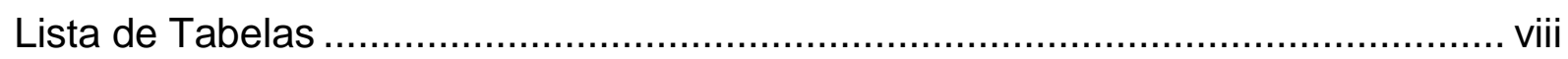

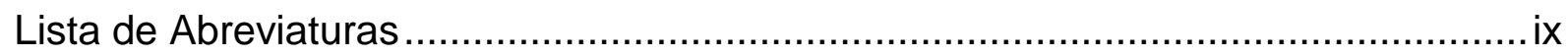

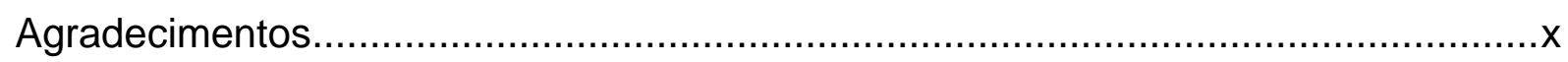

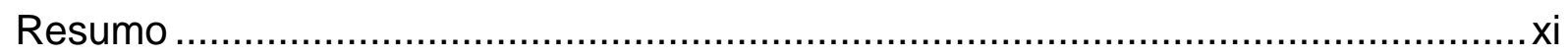

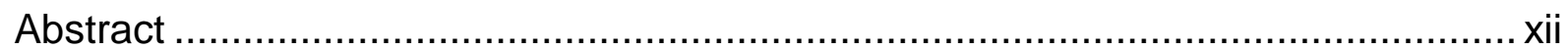

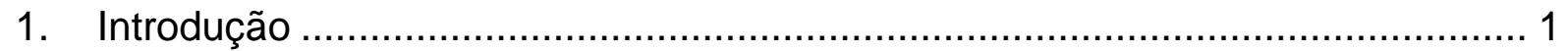

1.1. Sistemas Estuarinos..................................................................... 1

1.2. Ciclo e Comportamento Biogeoquímicos do Fósforo e do Silício em

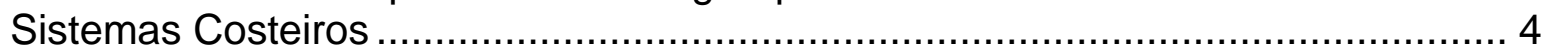

1.3. Especiação de Fósforo Sedimentar........................................................ 9

1.4. Fósforo e Impacto Ambiental............................................................ 10

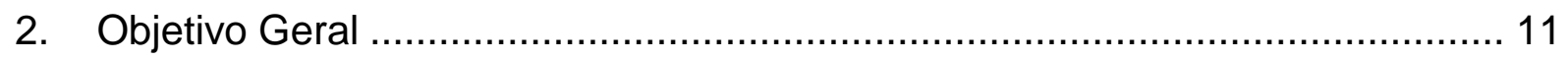

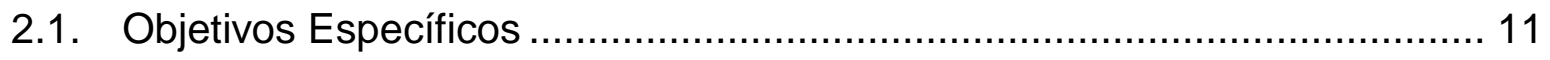

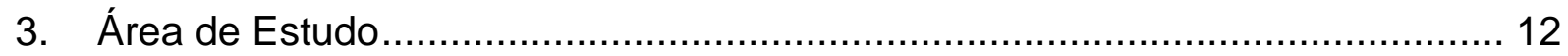

3.1. Complexo Estuarino-Lagunar de Cananeia-Iguape (SP) ......................... 12

3.2. A Formação Geológica do complexo estuarino-lagunar de Cananeia-Iguape (SP) 12

3.3. O Canal Artificial do Valo Grande ................................................................ 16

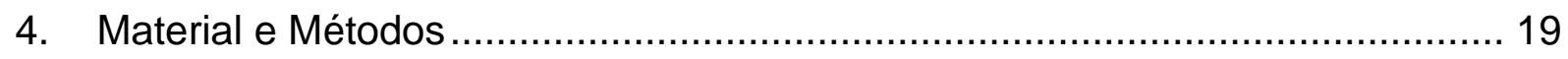

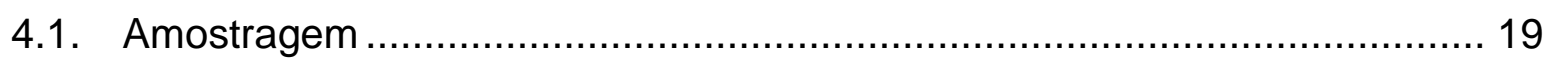

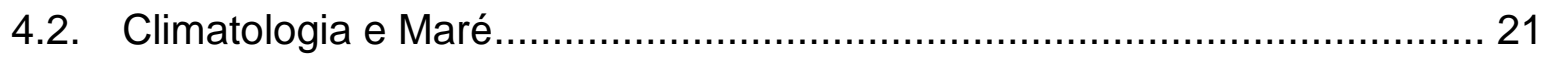

4.3. Hidrografia e Biogeoquímica na Coluna d'água ….................................. 21

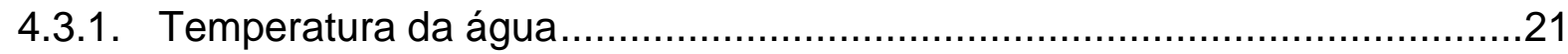

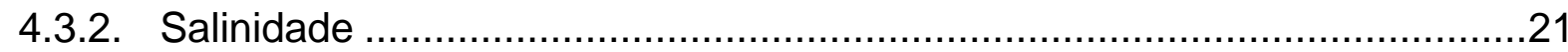

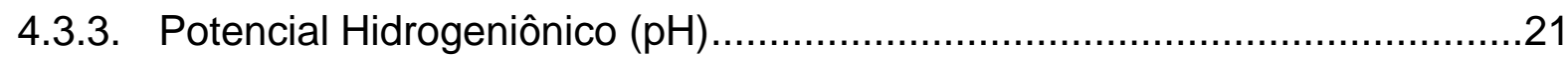

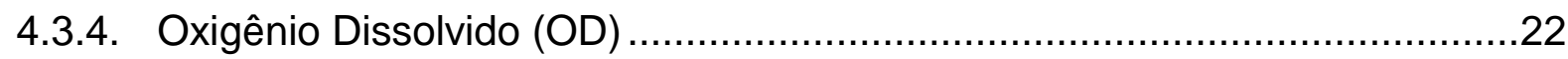

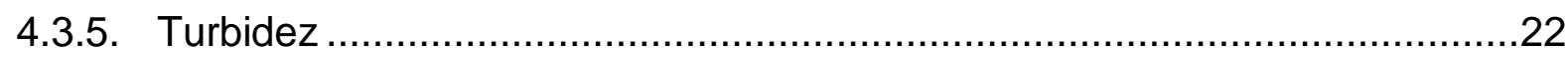

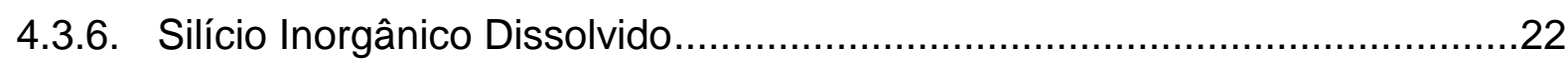

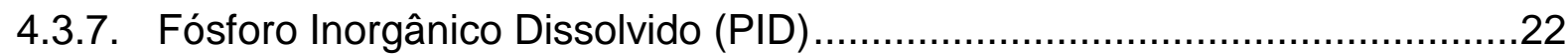

4.3.8. Fósforo Orgânico Dissolvido (POD) e Fósforo Total Dissolvido (PTD) ........23

4.3.9. Material Particulado em Suspensão (MPS) e Material Particulado Orgânico

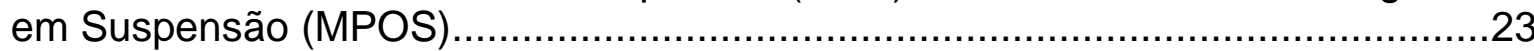

4.3.10. Fósforo no Material Particulado em Suspensão...........................................

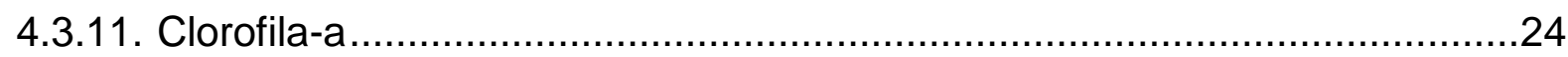


4.4. Parâmetros Sedimentares

4.4.1. Granulometria, Matéria Orgânica (MO) e Carbonato Biodetrítico

4.4.2. Extração Sequencial de Fósforo no Sedimento - SEDEX (P-bio; P-Fe; P-

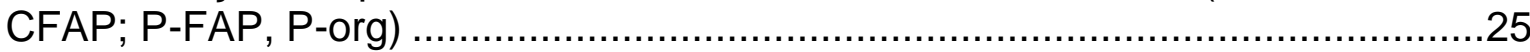

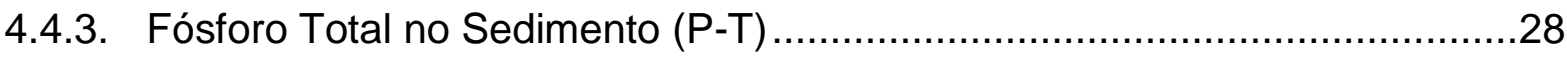

4.5. Validação da análise de Extração Sequencial do Fósforo no Sedimento

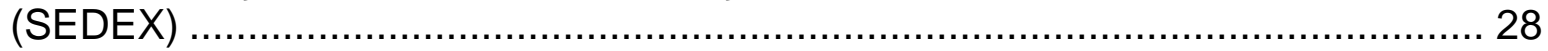

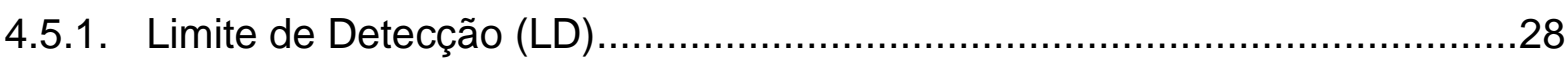

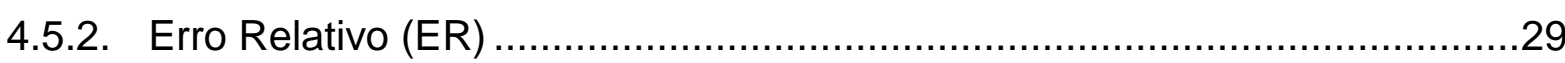

4.5.3. Resultados para a análise de Extração Sequencial do Fósforo no Sedimento (SEDEX)....

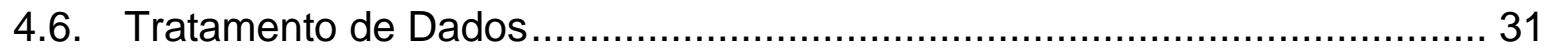

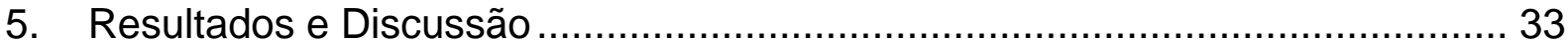

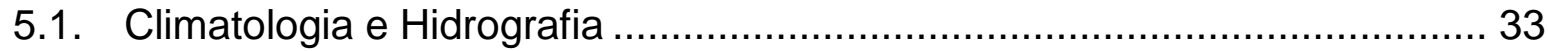

5.2. Hidrologia e Hidroquímica do sistema estuarino-lagunar de Cananeia-Iguape (SP) 37

5.3. Material Particulado em Suspensão (MPS) e Material Particulado Orgânico

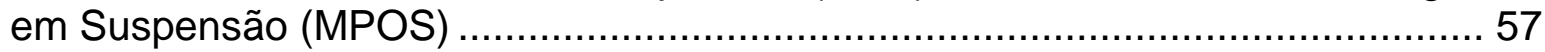

5.4. Fósforo Total Particulado em Suspensão (PTP), Fósforo Inorgânico Particulado em Suspensão (PIP) e Fósforo Orgânico Particulado em Suspensão

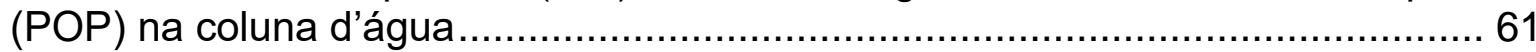

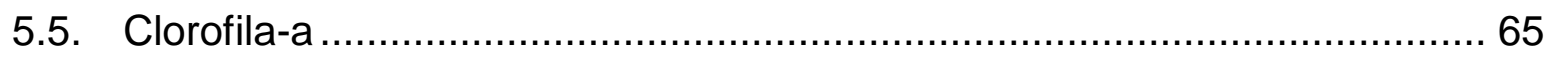

5.6. Parâmetros Sedimentares de Amostras Superficiais das Estações do Rio Ribeira de Iguape, Rio Guaraú, Sistema Estuarino-Lagunar de Cananeia-Iguape,

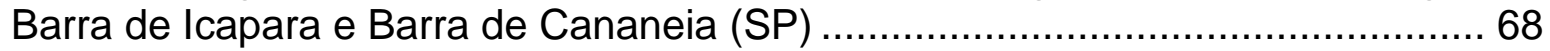

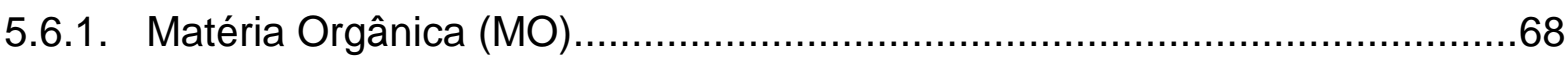

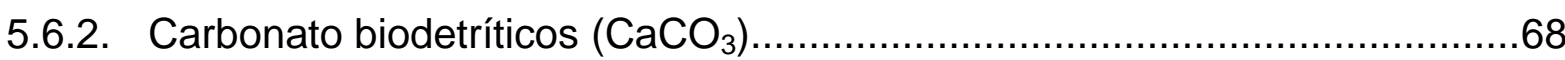

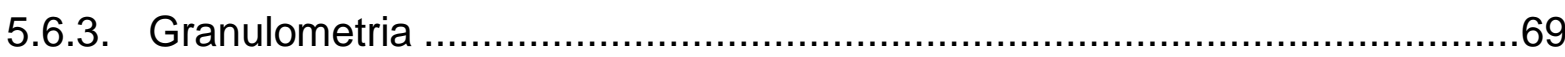

5.6.4. Extração Sequencial do Fósforo no Sedimento (SEDEX) em Amostras de Superfície do Rio Ribeira de Iguape, Rio Guaraú, Complexo Estuarino-Lagunar de Cananeia-Iguape, Barra de Icapara e Barra de Cananeia (SP) .......................75

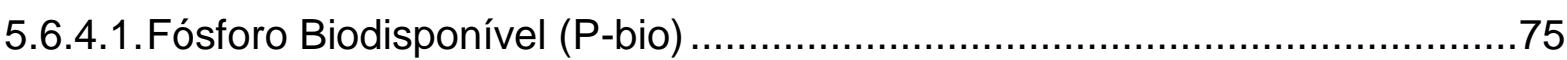

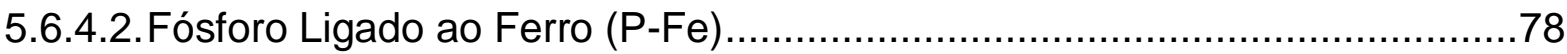

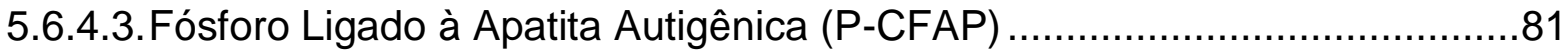

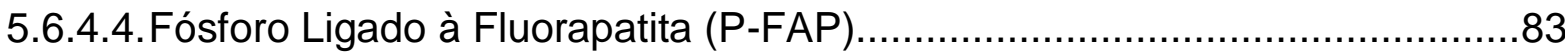

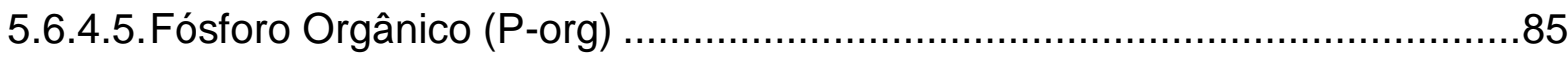

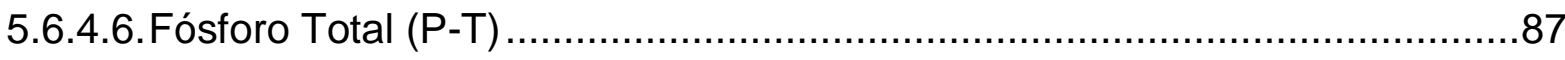

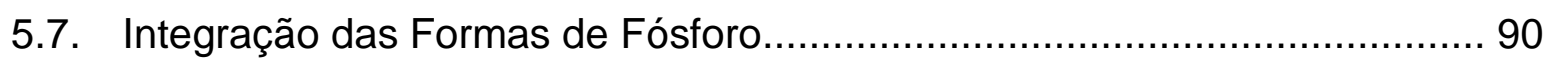




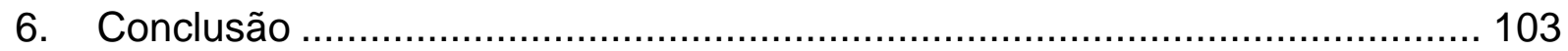

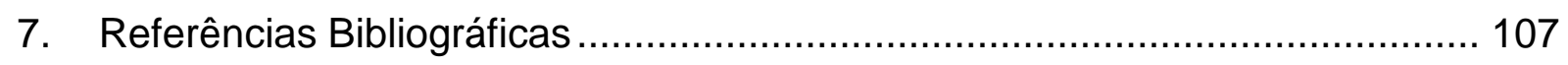

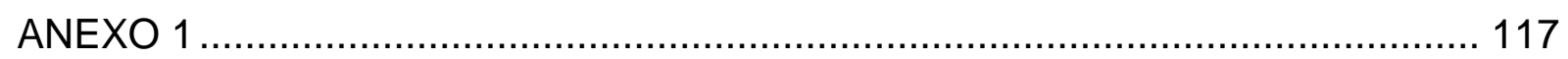

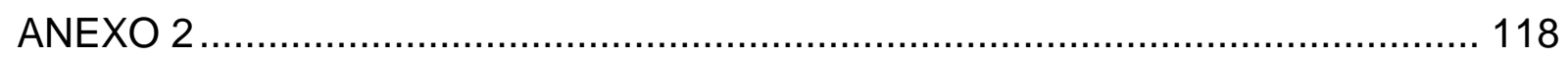




\section{Lista de Figuras}

Figura 1. Planície do rio Ribeira de Iguape e Complexo Estuarino-Lagunar de Cananeia-Iguape (SP) ............................................................................. 3

Figura 2. Ciclo biogeoquímico do Silício nos oceanos (BASTOS, 2014 )................. 5

Figura 3. Ciclo biogeoquímico do Fósforo. Modificado de Ruttenberg (2005)........... 6

Figura 4. Representação esquemática do papel dos sedimentos em suspensão nos processos biogeoquímicos estuarinos e costeiros. As caixas representam os compartimentos que hospedam materiais e constituintes químicos e as setas denotam processos biogeoquímicos. Modificado de Turner \& Millward (2002)......... 7

Figura 5. Modelo evolutivo da llha Comprida, proposto por Geobrás (1966). Fonte: Guedes (2009) ................................................................................. 13

Figura 6. Modelo evolutivo da llha Comprida, proposto por Giannini et al. (2003, 2009). Tempo 1 a 3 correspondem a $1^{\circ}$ e $2^{\circ}$ fase, tempo 4 a 6 correspondem a $3^{\circ}$ fase e Tempo 8 a $4^{\circ}$ fase. Fonte: Guedes (2009)...

Figura 7. Evolução da llha Comprida de 1.900 anos A.P. até o presente. (A) final do período de bloqueio da componente longitudinal pelos morros perto de Iguape (com duração aproximadamente 1.700 anos); (B) após a retomada do crescimento longitudinal (nos últimos 200 anos). Fonte: Guedes (2009). 16

Figura 8. Localização das estações de coleta de água e sedimento na região do complexo estuarino-lagunar de Cananeia-Iguape (SP). 20

Figura 9. Fluxograma da análise SEDEX. Adaptado de Ruttenberg (1992) e HuertaDiaz et al. (2005). 26

Figura 10. Precipitação mensal estação automática de Pariquera-Açú e Cananeia, com base nos dados divulgados em CIIAGRO, www.ciiagro.sp.gov.br, acesso em $26 / 02 / 2016$ 34

Figura 11. Curva de maré 21/08/2014, 26/08/2014 a 28/08/2014, com base nos dados divulgados em IOUSP, http://www.mares.io.usp.br/tabua/2014, acesso em 26/02/2016. 36

Figura 12. Curva de maré do dia 20 a 22/05/2015, com base nos dados divulgados em IOUSP, http://www.mares.io.usp.br/tabua/2015, acesso em 26/02/2016. 36

Figura 13. Distribuição espacial dos dados obtidos no complexo estuarino-lagunar de Cananeia-Iguape, Cajati e Registro (SP): temperatura $\left({ }^{\circ} \mathrm{C}\right)$ de agosto de 2014 (a) e maio de 2015 (d); salinidade de agosto de 2014 (b) e maio de 2015 (e); pH de agosto de 2014 (c) e maio de 2015 (f)............................................................. 40

Figura 14. Distribuição espacial dos dados coletados nos rios Guaraú, Ribeira de Iguape e canal do Valo Grande (SP): temperatura $\left({ }^{\circ} \mathrm{C}\right)$ de agosto de 2014 (a) e maio 
de 2015 (b); salinidade de agosto de 2014 (c) e maio de 2015 (d); pH de agosto de 2014 (e) e maio de 2015 (f); oxigênio dissolvido $\left(\mathrm{mL} \mathrm{L}^{-1}\right)$ de agosto de 2014 (g) e maio de 2015 (h). O losango azul representa os dados de superfície e o quadrado vermelho representa os dados de fundo 41

Figura 15. a) Imagem da amostragem de OD na estação Vale; b) Imagem aspecto do córrego que transporta o resíduo para as lagoas de decantação (Fonte: BRAGA, E.S., maio de 2015). 42

Figura 16. Distribuição espacial da turbidez (ntu) das estações dos rios Guaraú, Ribeira de Iguape e canal do Valo Grande (SP): agosto de 2014 (a) e maio de 2015 (b).

Figura 17. Diagrama de dispersão de silicato dissolvido $\left(\mu \mathrm{mol} \mathrm{L}^{-1}\right)$ com relação à salinidade: agosto de 2014 (a) e maio de 2015 (b) no sistema estuarino-lagunar de Cananeia-Iguape, Cajati e Registro (SP). 45

Figura 18. Distribuição espacial dos dados obtidos no complexo estuarino-lagunar de Cananeia-Iguape, Cajati e Registro (SP): Oxigênio Dissolvido-OD ( $\mathrm{ml} \mathrm{L}^{-1}$ ) de agosto de 2014 (a) e maio de 2015 (d); Turbidez (NTU) de agosto de 2014 (b) e maio de 2015 (e); Silicato $\left(\mu \mathrm{mol} \mathrm{L}{ }^{-1}\right)$ de agosto de 2014 (c) e maio de 2015 (f)................... 46

Figura 19. Distribuição espacial dos dados obtidos no complexo estuarino-lagunar de Cananeia-Iguape, Cajati e Registro (SP): Fósforo Inorgânico Dissolvido-PID ( $\mu \mathrm{mol} \mathrm{L}{ }^{-}$ $\left.{ }^{1}\right)$ de agosto de 2014 (a) e maio de 2015 (d); Fósforo Orgânico Dissolvido-POD ( $\mu \mathrm{mol} \mathrm{L} \mathrm{L}^{-1}$ ) de agosto de 2014 (b) e maio de 2015 (e); Fósforo Total Dissolvido-PTD $\left(\mu \mathrm{mol} \mathrm{L}{ }^{-1}\right)$ de agosto de 2014 (c) e maio de 2015 (f). 51

Figura 20. Distribuição espacial dos dados coletados nos rios Guaraú, Ribeira de Iguape e canal do Valo Grande (SP): Fósforo Inorgânico Dissolvido-PID ( $\mu \mathrm{mol} \mathrm{L}^{-1}$ ) de agosto de 2014 (a) e maio de 2015 (b); Fósforo Orgânico Dissolvido-POD ( $\mu \mathrm{mol}$ $\mathrm{L}^{-1}$ ) de agosto de 2014 (c) e maio de 2015 (d); Fósforo Total Dissolvido-PTD ( $\mu \mathrm{mol}$ $\mathrm{L}^{-1}$ ) de agosto de 2014 (e) e maio de 2015 (f). 52

Figura 21. Distribuição espacial dos dados coletados nos rios Guaraú, Ribeira de Iguape e canal do Valo Grande (SP) de Fósforo Inorgânico Dissolvido-PID ( $\mu \mathrm{mol} \mathrm{L}^{-1}$ ) de agosto de 2014 (a) e maio de 2015 (b). 55

Figura 22. Distribuição espacial dos dados coletados nos rios Guaraú, Ribeira de Iguape e canal do Valo Grande (SP) de Fósforo Orgânico Dissolvido-POD $\left(\mu \mathrm{mol} \mathrm{L}{ }^{-1}\right)$ de agosto de 2014 (a) e maio de 2015 (b) 56

Figura 23. Distribuição espacial dos dados obtidos no sistema estuarino-lagunar de Cananeia-Iguape, Cajati e Registro (SP): material particulado em suspensão (MPS) ( $\mathrm{mg} \mathrm{L}^{-1}$ ) de agosto de 2014 (a) e maio de 2015 (d); material particulado orgânico em suspensão (MPOS) (mg L-1) de agosto de 2014 (b) e maio de 2015 (e); material particulado orgânico em suspensão (MPOS) (\%) de agosto de 2014 (c) e maio de 2015 (f). 60 
Figura 24. Distribuição espacial dos dados obtidos no complexo estuarino-lagunar de Cananeia-Iguape, Cajati e Registro (SP): Fósforo Total Particulado-PTP $\left(\mu \mathrm{mol} \mathrm{g}{ }^{-1}\right)$ de agosto de 2014 (a) e maio de 2015 (d); Fósforo Inorgânico Particulado-PIP ( $\mu \mathrm{mol}$ $\mathrm{g}^{-1}$ ) de agosto de 2014 (b) e maio de 2015 (e); Fósforo Orgânico Particulado-POP $\left(\mu \mathrm{mol} \mathrm{g}{ }^{-1}\right)$ de agosto de 2014 (c) e maio de 2015 (f).

Figura 25. Distribuição espacial dos dados de clorofila-a $\left(\mathrm{mg} \mathrm{m}^{-3}\right)$ coletados no rio Ribeira de Iguape, complexo estuarino-lagunar de Cananeia-lguape, Barras de Cananeia e Icapara (SP), agosto de 2014. 66

Figura 26. Distribuição espacial dos dados de clorofila-a $\left(\mathrm{mg} \mathrm{m}^{-3}\right)$ coletados no rio Ribeira de Iguape, complexo estuarino-lagunar de Cananeia-lguape, Barras de Cananeia e Icapara (SP), maio de 2015.

Figura 27. Distribuição espacial dos dados granulométricos em sedimentos do rio Ribeira de Iguape, sistema estuarino-lagunar de Cananeia-Iguape, Barra de Icapara e Barra de Cananeia (SP). Agosto de 2014. 71

Figura 28. Diagrama de Shepard com dados granulométricos em sedimentos do rio Ribeira de Iguape, sistema estuarino-lagunar de Cananeia-Iguape, Barra de Icapara e Barra de Cananeia (SP). Agosto de 2014. 72

Figura 29. Distribuição espacial dos dados granulométricos em sedimentos do rio Ribeira de Iguape, rio Guaraú e sistema estuarino-lagunar de Cananeia-Iguape (SP). Maio de 2015. 73

Figura 30. Diagrama de Shepard com dados granulométricos em sedimentos do rio Ribeira de Iguape, Rio Guaraú e sistema estuarino-lagunar de Cananeia-Iguape (SP). Maio de 2015. 74

Figura 31. Distribuição espacial das concentrações de P-bio $\left(\mu \mathrm{mol} \mathrm{g} \mathrm{g}^{-1}\right)$ de amostras sedimentares do Rio Guaraú, Rio Ribeira de Iguape e complexo estuarino-lagunar de Cananeia-Iguape (SP), em Agosto de 2014 e Maio de 2015. 77

Figura 32. Distribuição espacial das concentrações de P-Fe $\left(\mu \mathrm{mol} \mathrm{g}{ }^{-1}\right)$ de amostras sedimentares do Rio Guaraú, Rio Ribeira de Iguape e complexo estuarino-lagunar de Cananeia-Iguape (SP), em Agosto de 2014 e Maio de 2015. 79

Figura 33. Distribuição espacial das concentrações de P-CFAP $\left(\mu \mathrm{mol} \mathrm{g}^{-1}\right)$ de amostras sedimentares do Rio Guaraú, Rio Ribeira de Iguape e complexo estuarinolagunar de Cananeia-Iguape (SP), em Agosto de 2014 e Maio de 2015.

Figura 34. Distribuição espacial das concentrações de P-FAP $\left(\mu \mathrm{mol} \mathrm{g}{ }^{-1}\right)$ de amostras sedimentares do Rio Guaraú, Rio Ribeira de Iguape e complexo estuarino-lagunar de Cananeia-Iguape (SP), em Agosto de 2014 e Maio de 2015. 84

Figura 35. Distribuição espacial das concentrações de P-org $\left(\mu \mathrm{mol} \mathrm{g}{ }^{-1}\right)$ de amostras sedimentares do Rio Guaraú, Rio Ribeira de Iguape e complexo estuarino-lagunar de Cananeia-Iguape (SP), em Agosto de 2014 e Maio de 2015. 86 
Figura 36. Distribuição espacial das concentrações de P-T $\left(\mu \mathrm{mol} \mathrm{g} \mathrm{g}^{-1}\right)$ de amostras sedimentares do Rio Guaraú, Rio Ribeira de Iguape e complexo estuarino-lagunar de Cananeia-Iguape (SP), em Agosto de 2014 e Maio de 2015. 88

Figura 37. Distribuição espacial das porcentagens das fases P-bio, P-Fe, P-CFAP, P-FAP e P-org em relação ao P-T de sedimentos de superfície do rio Guaraú, rio Ribeira de Iguape ,complexo estuarino-lagunar de Cananeia-Iguape, Barra de Cananeia e de Icapara (SP): a) em agosto de 2014 e b) em maio de 2015............ 90

Figura 38. Diagrama de dispersão de fosfato inorgânico dissolvido - PID $\left(\mu \mathrm{mol} \mathrm{L} \mathrm{L}^{-1}\right)$ com relação à salinidade: agosto de 2014 no rio Ribeira de Iguape, sistema estuarino-lagunar de Cananeia-Iguape, Barras de Cananeia (Sul) e de Icapara (norte) (SP)

Figura 39. Representação do ciclo do fósforo no complexo estuarino-lagunar de Cananeia-Iguape (SP) no transecto N-S, com base na porcentagem de adsorção do PID (\%PID) utilizando os dados de Agosto de 2014. 98

Figura 40. Representação do ciclo do fósforo no complexo estuarino-lagunar de Cananeia-Iguape (SP) no transecto N-S, com base na porcentagem de adsorção do PIP (\%PID) utilizando os dados de Maio de 2015. 101 


\section{Lista de Tabelas}

Tabela 1. Limites de Detecção das fases da extração sequencial do fósforo no sedimento. 30

Tabela 2. Especiação sedimentar do fósforo através do MCR MESS-3 pelo método SEDEX (Ruttenberg, 1992) e CDB-MAGIC (Huerta Diaz et al., 2005) 30

Tabela 3. Eficiência da extração de $P$ sedimentar pelo método SEDEX (Ruttenberg, 1992) e CDB-MAGIC (Huerta Diaz et al., 2005). 31

Tabela 4. Precipitação total anual nos anos de 2014 e 2015 nas cidades de Pariquera-Açú e Cananeia, disponível em CIIAGRO, www.ciiagro.sp.gov.br, acesso em 26/02/2016.

Tabela 5. Quadro sinóptico na situação do sistema em Agosto de 2014. .65

Tabela 6. Quadro sinóptico na situação do sistema em Maio de 2015. 65

Tabela 7. Quadro sinóptico dos dados de sedimentos em amostras do rio Rio Ribeira de Iguape, rio Guaraú, sistema estuarino-lagunar de Cananeia-Iguape, Barra de Icapara e Barra de Cananeia (SP). 75

Tabela 8. Estatística descritiva dos dados da extração de fósforo sequencial no sedimento (SEDEX) nas frações P-bio, P-Fe, PCFAP, P-FAP,P-org e P-T em amostras do Estuário de Cananeia-Iguape e Rio Riberia de Iguape (SP) da campanha de agosto de $2014(\mathrm{n}=20)$ e maio de $2015(\mathrm{n}=17)$..

Tabela 9. Valores de $\triangle$ PID e \%DIP com as estações estuarinas (1-11) do complexo estuarino-lagunar de Cananeia-Iguape (S), agosto de 2014 e maio de 2015. 95

Tabela 10. Correlação de Pearson com todos os parâmetros amostrados no Rio Guaraú, Rio Ribeira de lguape, sistema estuarino-lagunar de Cananeia-lguape, Barras de Cananeia e Icapara (SP), agosto de $2014(\mathrm{n}=48)$. 117

Tabela 11. Correlação de Pearson com todos os parâmetros amostrados no Rio Guaraú, Rio Ribeira de lguape, sistema estuarino-lagunar de Cananeia-Iguape, Barras de Cananeia e Icapara (SP), maio de 2015 ( $n=31)$. 118 


\section{Lista de Abreviaturas}

\%PID Porcentagem de Remoção do Fósforo Inorgânico Dissolvido

$\triangle P I D \quad$ Fósforo Inorgânico Adsorvido ou Dessorvido

A.P. Antes do Presente

CIIAGRO Centro Integrado de Informações Agrometeorológicas

LABNUT Laboratório de Biogeoquímica de Nutrientes, Micronutrientes e Traços nos Oceanos

OD Oxigênio Dissolvido

P Fósforo

P-bio Fósforo Biodisponível ou Fracamente Ligado no Sedimento

P-CFAP Fósforo Ligado à Apatita Biogênica, Carbonato Fluorapatita e $\mathrm{P}$ Adsorvido a $\mathrm{CaCO}_{3}$ no Sedimento

P-FAP Fósforo Ligado à Fluorapatita de Origem Litogênica no Simento

$\mathrm{P}-\mathrm{Fe} \quad$ Fósforo Ligado à Oxi-Hidróxidos de Ferro no Sedimento

pH Potencial Hidrogeniônico

PID Fósforo Inorgânico Dissolvido

PIP Fósforo Inorgânico Particulado em Suspensão

POD Fósforo Orgânico Dissolvido

POP Fósforo Orgânico Particulado em Suspensão

P-org Fósforo Orgânico no Sedimento

P-T Fósforo Total no Sedimento

PTD Fósforo Total Dissolvido

PTP Fósforo Total Particulado em Suspensão

SEDEX Extração Sequencial de Fósforo no Sedimento

Si Silício 


\section{Agradecimentos}

Agradeço primeiramente à minha família que sempre me apoiou e esteve ao meu lado até mesmo nos momentos mais difíceis. Principalmente aos meus pais Walter e Telma, e minha irmã Jessika, que nunca me impediram de sonhar, vocês são a base do que sou. Amo-os imensuravelmente. À minha prima Aline, parceira de vida.

Ao namorado e companheiro de vida José Donato, obrigada pelo apoio e carinho.

À minha orientadora Prof. Elisabete de Santis Braga por tantos anos de trabalho, desde o Museu de Ciências, pela amizade, pelo carinho e por me guiar neste trabalho.

À FUNDESPA (Fundação de Estudos e Pesquisas Aquáticas) de pela concessão da bolsa de mestrado.

Ao CNPq pelo apoio financeiro concedido ao projeto Febiogeoquim Proc. 478890/2011-7.

À tripulação da embarcação de Pesquisa "Albacora" pelo trabalho pesado, a conversa boa e pelo bolinho quente do final da tarde, muito obrigada Adriano, Evandiro, Sergio e Ulisses. À todos os funcionários da Base Sul de Pesquisa "Dr. João de Paiva Carvalho", situada na cidade de Cananéia, pelo apoio durante as atividades de campo.

À tripulação da Embarcação de Pesquisa "Alpha Delphini” pelos dias de mar calmo e muito trabalho.

À todos os funcionários do IO-USP. Ao Gilberto e o Elvis, que me ajudaram a fazer as análises granulométricas. Especialmente aos funcionários do setor de manutenção que sempre foram muito atenciosos e prontos para ajudar, ou fazer aquela feijoada, muito obrigada Piauí. Ao Wilson Natal que sempre nos acompanha nas jornadas de campo. À Ana Paula, Letícia e ao Daniel, obrigada pela atenção e paciência. À todos os funcionários da biblioteca, pela atenção, disposição e sorriso no rosto. À Silvana. Ao Éder e ao Ricardo, pela ajuda com os computadores e com a impressão, muito obrigada.

Aos amigos do Labnut e da vida, por todo o companheirismo nesta jornada, pelos trabalhos de campo, pelas análises intermináveis e pelas risadas: Ana, Aninha, Bruno, Caio, Chiara, Gabriela, João, Kátia, Renata, Leonardo, Victor e Vitor. Quero agradecer especialmente a Chiara, a Ana e ao Vitor, formamos uma ótima equipe, vocês estão em meu coração.

Aos amigos do Grupo de Pesquisa Nostramos do Departamento de Geografia da Universidade de São Paulo.

Às amigas do LDC: Bruna, Carol e Lilian pelas risadas no almoço e a animação para ir para a aula de fitness. À Bia pela amizade e as conversas com café. À Isabel e ao Otávio, pela ajuda. Ao Amilcar pelo almoço e pelas risadas nesta reta final. À Didi e ao Bertão pelo café de todo dia. À Aline, Fabiana e Gabriel, por me tirarem de casa num dia em que a cabeça estava fundindo. 


\section{Resumo}

Este trabalho teve como objetivo estudar as diferentes formas do fósforo (dissolvida, particulada e sedimentar) ao longo do complexo estuarino-lagunar de Cananeia-Iguape (SP) considerando o impacto antrópico regional causado pela abertura do canal do Valo Grande, observando o processo de ciclagem biogeoquímica do fósforo na coluna d' água e no sedimento. O sistema foi caracterizado por meio de parâmetros hidrológicos, hidroquímicos e sedimentológicos, com enfase a formas do fósforo na água (fósforo inorgânico dissolvido, fósforo orgânico dissolvido, fósforo inorgânico particulado e fósforo orgânico particulado) e sua especiação no sedimento (fósforo biodisponível, fósforo ligado à oxi-hidróxidos de ferro, fósforo ligado à apatita autigênica, fósforo ligado à fluorapatita, fósforo orgânico e fósforo total). Para tanto foram realizadas duas coletas amostrais, uma em agosto de 2014 (inverno) composta por 20 estações, e outra em maio de 2015 (outono) com 19 estações. De posse destes dados foi possível observar no complexo estuarino dois comportamentos distintos, regidos principalmente pela influência do rio Ribeira de lguape. Os valores mais altos fósforo dissolvido (valores de PID próximos à $10 \mu \mathrm{mol} \mathrm{L}^{-1} \mathrm{em}$ agosto de 2014 e à $5 \mu \mathrm{mol} \mathrm{L} \mathrm{L}^{-1}$ em maio de 2015) e particulado (PIP foi de aproximadamente $70 \mu \mathrm{mol} \mathrm{g}^{-1} \mathrm{em}$ agosto de 2014 e $60 \mu \mathrm{mol} \mathrm{g}{ }^{-1}$ em maio de 2015) indicando a influência dos materiais e água doce introduzidos no sistema via Valo Grande. No sedimento esta distribuição foi menos evidente, recebendo maior influência da granulometria e dos processos de deposição sedimentar (P-T de aproximadamente $16 \mu \mathrm{mol} \mathrm{g} \mathrm{g}^{-1}$ e P-Fe próximo à 9 $\left.\mu \mathrm{mol} \mathrm{g}^{-1}\right)$. Existe uma grande possibilidade de a mineração contribuir antropicamente ao aporte de fosforo especialmente na forma inorgânica. No sistema estuarino como um todo as formas particuladas de fósforo tiveram valores mais elevados que as dissolvidas, indicando um processo ativo de adsorção do fósforo ao material particulado. O setor sul apresenta concentrações menores de fósforo, indicando a maior influência marinha. Este estudo caracterizou o complexo estuarino-lagunar de Cananeia-Iguape como retentor de fósforo.

Palavras-chave: fósforo, estuário, rio Ribeira de Iguape, Cananeia, especiação do fósforo, sedimento, material particulado. 


\section{Abstract}

This work aimed to study the different phosphorus forms (dissolved, particulate and sedimentary) along the Cananeia-Iguape estuarine-lagoon complex (SP) considering the regional anthropic impact caused by the opening of the Valo Grande channel, observing the process of biogeochemical cycling of phosphorus in the water column and sediment. The system was characterized by means of hydrological, hydrochemical and sedimentological parameters, with emphasis in phosphorus forms in water (dissolved inorganic phosphorus, dissolved organic phosphorus, particulate inorganic phosphorus and particulate organic phosphorus) and speciation in sediment (loosely sorbed phosphorus, ferric ironbound phosphorus, authigenic apatite biogenic apatite $\mathrm{CaCO}_{3}$-bound phosphorus, detrital apatite, organic phosphorus and total phosphorus). To this end there were two sample collections, one in August 2014 (winter) with 20 stations, and another in May 2015 (autumn) with 19 stations. Based on these data two distinct behaviors were observed in the system. They are mainly governed by the influence of the Ribeira de lguape river. The northern sector showed higher values of dissolved (values of PID near $10 \mu \mathrm{mol} \mathrm{L}{ }^{-1}$ in August 2014 and $5 \mu \mathrm{mol} \mathrm{L}{ }^{-1}$ in May 2015) and particulate phosphorus (PIP was approximately $70 \mu \mathrm{mol} \mathrm{g}{ }^{-1}$ in August 2014 and about $60 \mu \mathrm{mol} \mathrm{g}^{-1}$ in May 2015), indicating the influence of materials and fresh water input into the system via Valo Grande. In the sediment this distribution was less evident, being more influenced by grain size and sediment deposition processes (P-T was approximately $16 \mu \mathrm{mol} \mathrm{g} \mathrm{g}^{-1}$ and P-Fe near $9 \mu \mathrm{mol} \mathrm{g} \mathrm{g}^{-1}$ ). There is a great possibility mining was the main anthropic activity that contributes to phosphorus input especially in the inorganic form. In the estuarine system as a whole, phosphorus particulate forms were higher than those dissolved, indicating an active dissolved phosphorus adsorption process on the particulate material. The southern sector has lower phosphorus concentrations, indicating the greater marine influence. This study characterized the Cananeia-Iguape estuarine-lagoon complex as phosphorus retainer.

Key-words: phosphorus, estuary, Ribeira de Iguape river, Cananeia, especiation of phosphorus, sediment, particulate matter. 


\section{Introdução}

\subsection{Sistemas Estuarinos}

Os sistemas estuarinos são de grande importância ecológica oceânica e continental. Atuam como berçários para diversas espécies e organismos marinhos pelo alimento farto e a proteção dos predadores. Também é local de aporte de nutrientes para o oceano através das barras, considerado também ambiente filtrador na ciclagem de nutrientes. Para o continente, o sistema atua como importante área econômica (por exemplo: pesca, turismo, aquicultura), também opera como área de recebimento (da bacia de drenagem) e transporte de materiais para o oceano.

Como relatado em Miranda et al. (2012) Pritchard (1995) definiu estuário como: “(...) um corpo de água costeiro semifechado, com uma livre ligação com o oceano aberto, no interior do qual a água do mar é mensuravelmente diluída pela água doce oriunda da drenagem continental”. As águas marinhas, mais densas, adentram aos estuários pelo fundo, gerando, dependendo da intensidade da maré, processos turbulentos de mistura, denominados de difusão turbulenta (Miyao et al., 1986).

Os nutrientes transportados via fluvial ao entrarem nos estuários sofrem processos biogeoquímicos, que conferem a esta região costeira a função de filtro para o material dissolvido e particulado (CARTER, 1988). Tratando-se do fósforo (P) e do silício (Si) nos estuários, estes podem integrar a produção primária e também podem sofrer processos de adsorção e desorção com o sedimento.

Os sedimentos contidos no sistema estuarino possuem fonte ligada a bacia de drenagem a montante, a plataforma continental, a erosão das margens e do fundo do canal estuarino, da atividade biológica e de aportes antrópicos que venham a ocorrer (MCDOWELL, O'CONNOR, 1977). O transporte de material tende a ser maior pela drenagem, do que nos estuários, devido ao processo de deposição que ocorre na Zona de Máxima Turbidez (ZMT) em estuários parcialmente misturados.

A ZMT é gerada por interações complexas entre a morfologia do canal, assimetria da maré, circulação gravitacional e a composição e textura do sedimento (FITZSIMONS et al., 2011), essa configuração acarreta na floculação, onde as partículas em suspensão se ligam ionicamente. 
Neste trabalho será estudado o complexo estuarino-lagunar de CananeiaIguape localizado no setor sul do litoral do Estado de São Paulo (Fig. 1), uma expressiva área com cerca de 2 milhões de hectares de Mata Atlântica (cerca de $21 \%$ dos remanescentes do país), está dentro dos limites da Área de Proteção Ambiental (Decreto Estadual 90.347 e Decreto Federal 91.829 de 23 de outubro de 1984), é considerada pela United Nations Educational Scientific and Cultural Organization (UNESCO) como Reserva da Biosfera da Mata Atlântica e Patrimônio Mundial Natural da Humanidade (UNESCO, 2005). É uma região de alta complexidade hidrológica apresentando distinção entre as atividades e a ocupação do solo nas regiões norte e sul do sistema.

Esta região tem sido impactada antropicamente no setor norte devido à construção do Canal do Valo Grande que alterou o fluxo de água doce e sedimentos em suspensão para o sistema estuarino, modificando as entradas de P e Si nas formas dissolvidas e particuladas, alterando também, o perfil de distribuição da salinidade que pode afetar o perfil dos ciclos biogeoquímicos destes elementos no ambiente. 


\section{Planície do Rio Ribeira de Iguape e Complexo Estuarino-Lagunar de Cananeia-Iguape (SP)}

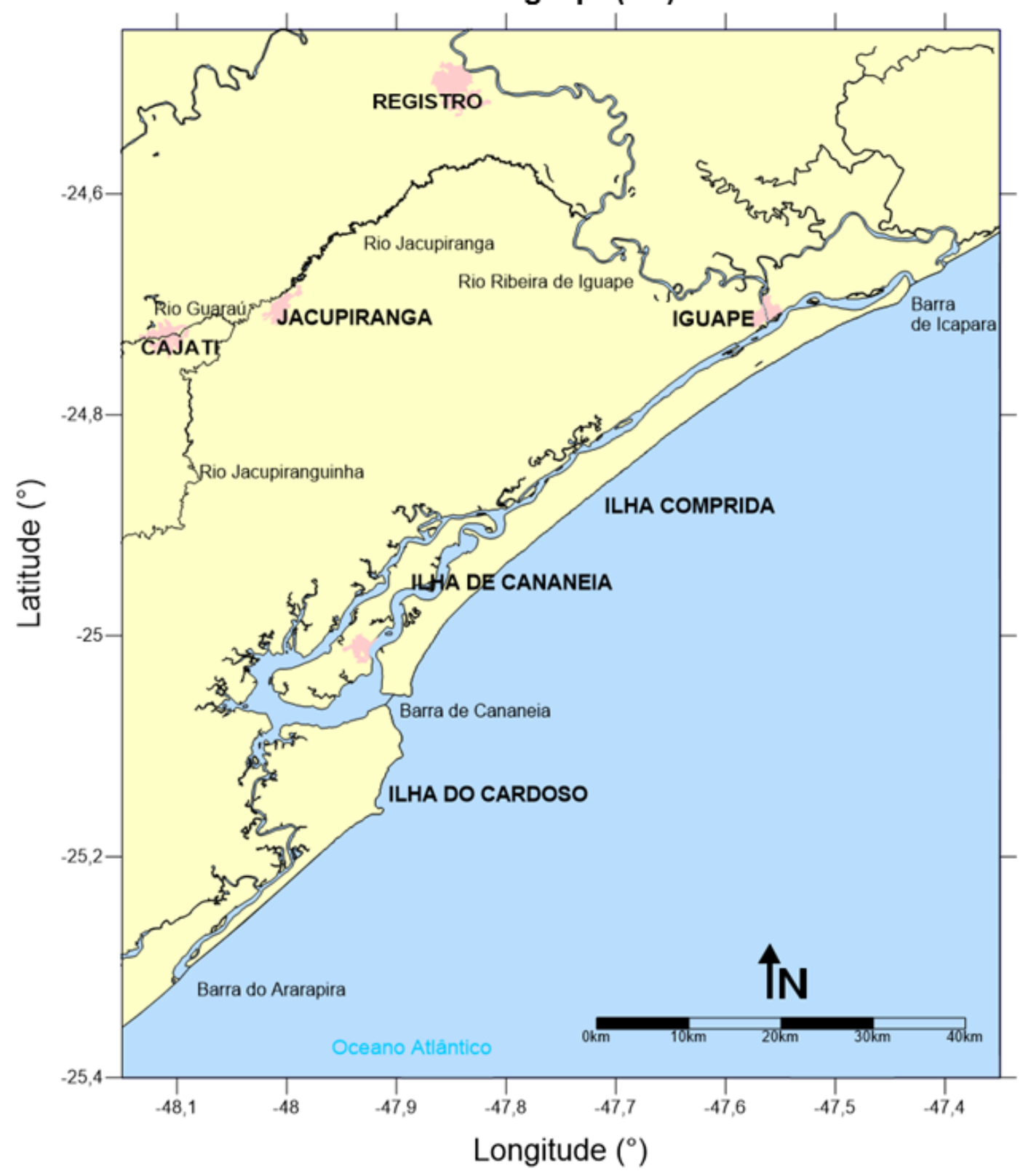

Legenda

Hidrografia

Porção Terrestre

Área Urbana
Fonte: Hidrografia Bifiliar. SIG-RB, 2010. Shapefile. Escala 1:250.000

Disponivel em: http://www. sigrb.com. br/projetos/consulta. php?id=15. Acesso em: 29 abr. 2015

Projeção UTM. Datum horizontal WGS 89.

Base Cartográfica: IBGE, 1: 250.000, 2015

Figura 1. Planície do rio Ribeira de Iguape e Complexo Estuarino-Lagunar de Cananeia-Iguape (SP). 


\subsection{Ciclo e Comportamento Biogeoquímicos do Fósforo e do Silício em Sistemas Costeiros}

O fósforo $(\mathrm{P})$ e o silício ( $\mathrm{Si}$ ) são elementos que tem origem em sistemas terrestres e podem ser utilizados como traçadores de material aportado pelos continentes aos sistemas hídricos. Diante de alterações ambientais, tanto de origem natural como de origem antrópica, estes elementos podem apresentar modificações em seus fluxos e, consequentemente, em seus ciclos biogeoquímicos, no equilíbrio entre as suas formas químicas e também na partição entre elas.

Muitas rochas possuem em suas constituições minerais da classe do fosfato e do silicato, principalmente dos feldspatos que correspondem a cerca de $60 \%$ da crosta terrestre (SiAl). Ambos os elementos atingem o ecossistema aquático principalmente por meio do intemperismo de rochas e lixiviação de solos, porém estes processos podem ser intensificados por atividades antrópicas como a erosão, ocupação indevida do solo, incremento das descargas de fontes domésticas, industriais e agrícolas.

O P e o Si fazem parte do grupo de elementos considerados nutrientes principais no meio marinho, pois participam da constituição dos organismos que são a base da cadeia alimentar, os produtores primários. De um modo geral o fitoplâncton possui em sua composição básica os elementos: carbono, hidrogênio, oxigênio, nitrogênio, fósforo, enxofre e demais micronutrientes. As diatomáceas possuem carapaça que pode ser constituída de cálcio ou de silício (SARMIENTO, GRUBER, 2006).

A distribuição dos nutrientes principais ( $N, P$ e Si) é controlada por agentes biológicos, físicos e químicos específicos do ecossistema aquático (ALLANSON, WINTER, 1999; MIRANDA et al., 2012), sendo também influenciada pelas alterações climáticas e pela ação antrópica geradas nos ambientes costeiros as quais podem provocar alterações nos ciclos biogeoquímicos dos nutrientes e de elementos traços, com consequências nos diferentes ecossistemas.

O ciclo biogeoquímico do Si (Fig. 2) envolve diversos ambientes, estuarinos, polares, tropicais, temperados, equatoriais podendo ser costeiros e oceânicos. $\mathrm{Na}$ forma dissolvida este elemento possui um importante papel no controle do $\mathrm{pH}$ e na 
produção primária oceânica global, que vinculam o $\mathrm{Si}$ ao sequestro de $\mathrm{CO}_{2}$ via bomba biológica (SMITH, GATTUSO, 2009; LIBES, 2009; BASTOS, 2014).

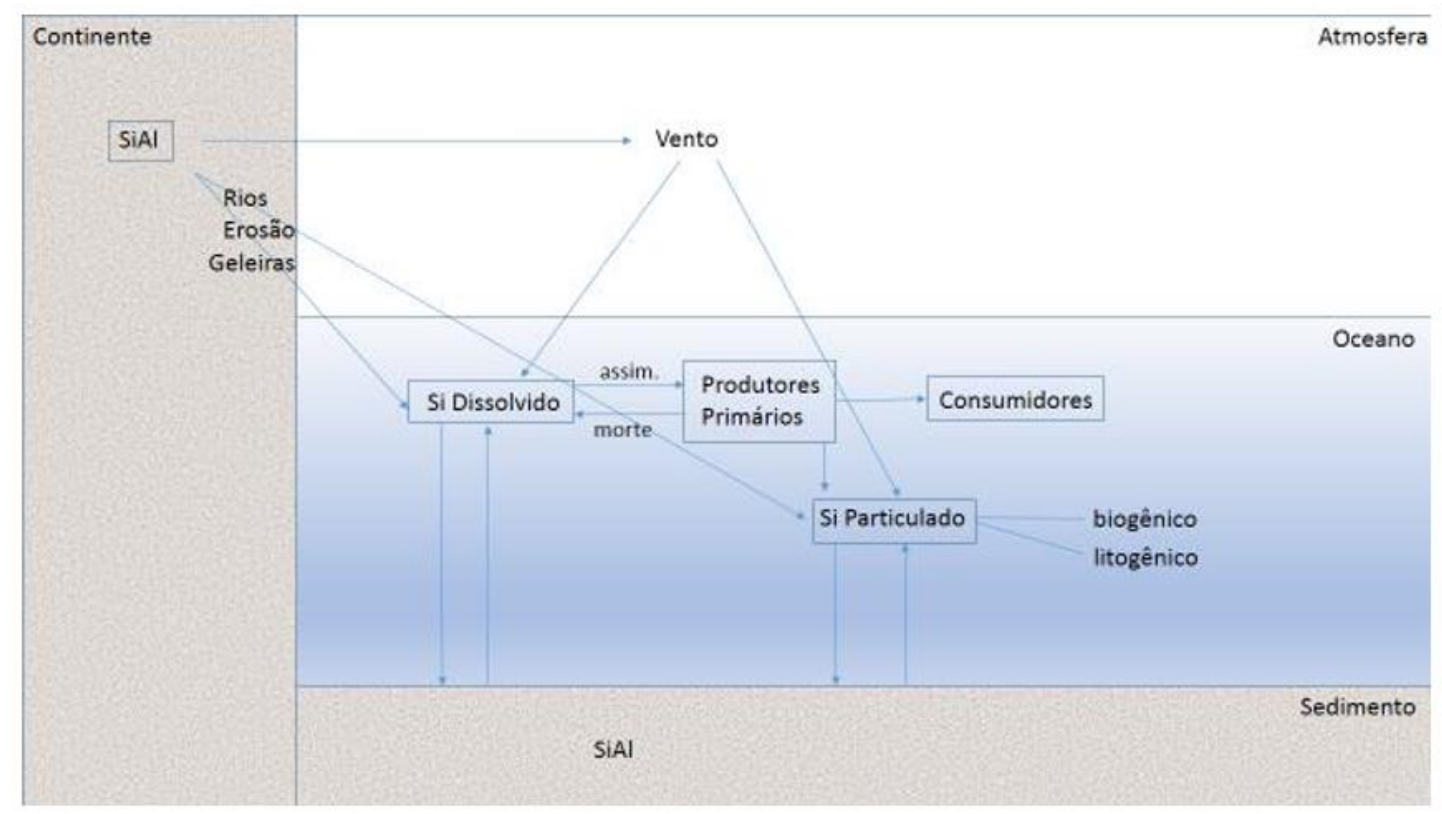

Figura 2. Ciclo biogeoquímico do Silício nos oceanos (BASTOS, 2014 ).

Cerca de $80 \%$ das diversas formas de silício (silício inorgânico dissolvido, silício particulado litogênico e biogênico), chegam aos estuários e oceanos transportados via drenagem (TREGUÉR et al., 1995), uma parcela pequena entra nos sistemas através de aporte atmosférico. As regiões costeiras possuem importante papel neste ciclo, pois nestes locais ocorrem afundamento e retenção de silício biogênico durante seu transporte para o oceano (RAGUENEAU et al., 2006). Sendo assim, o silício pode ser um excelente parceiro no estudo do $\mathrm{P}$ em sistemas costeiros, que recebem importante aporte de rios como é o caso do sistema em estudo.

O fósforo é um elemento que participa de processos fundamentais do metabolismo dos seres vivos, através de seu papel na formação de biomoléculas como ATP, DNA, RNA entre outras, desta forma seu ciclo biogeoquímico (Fig. 3) está atrelado a outros elementos bioativos como o carbono, oxigênio e nitrogênio. No meio aquático, o $\mathrm{P}$ muitas vezes atua como elemento limitante na produção primária de matéria orgânica pelo fitoplâncton marinho. O aporte fluvial é o mais importante mecanismo de entrada do fósforo de origem continental no sistema 
hídrico, sendo que cerca de $90 \%$ deste material está associado aos sólidos em suspensão na água ou ao material particulado em suspensão (MEYBECK, 1982).

Em águas naturais, o $\mathrm{P}$ está presente na forma orgânica e inorgânica, nas fases dissolvida, coloidal, particulada em suspensão, nos sedimentos e também nos organismos vivos. A dinâmica entre as fases de $\mathrm{P}$ dissolvido, coloidal e particulado e seu transporte para ambientes estuarinos, ainda é pobremente entendido (LIN et al., 2012).

Prastka et al. (1998), indicam que a liberação e a remoção de PID em ambientes estuarinos, pode estar relacionada com a exportação fluvial de PID e com o transporte do material particulado em suspensão e ao coeficiente de partição $\left(k_{d}\right)$ do $P$ entre as fases dissolvida e particulada.

Além disso, existem processos biológicos de assimilação, assim, o ciclo biogeoquímico do $\mathrm{P}$ envolve a interação de processos biológicos, químicos e geológicos, que são influenciados por aspectos físicos da hidrodinâmica.

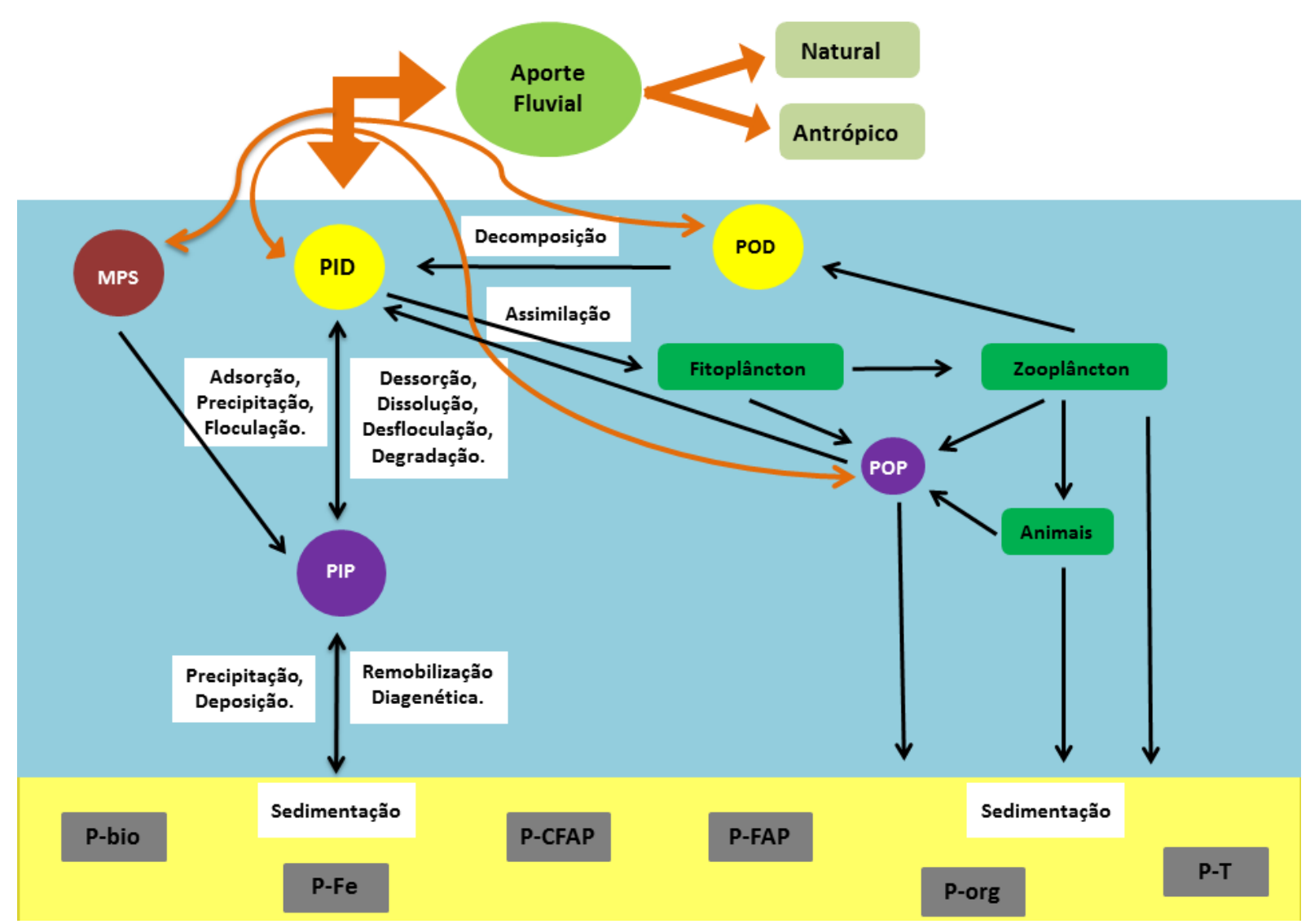

Figura 3. Ciclo biogeoquímico do Fósforo. Modificado de Ruttenberg (2005). 
O ciclo biogeoquímico do $\mathrm{P}$ atua nas fases dissolvida (inorgânica, orgânica $\mathrm{e}$ total), particulada (inorgânica, orgânica e total) e na sedimentar (fósforo biodisponível, fósforo ligado ao ferro, fósforo ligado à apatita autigênica, fósforo ligado à fluorapatita, fósforo orgânico e fósforo total), entre estes compartimentos dependendo da condição ambiental da coluna d' água há o favorecimento de determinados processos biogeoquímicos.

No sistema estuarino o fósforo tem seu processo de remoção associado à adsorção, precipitação, floculação e assimilação pela atividade biológica. Ao ser removido o fósforo dissolvido passa para a forma particulada na fase inorgânica ou orgânica dependendo das condições ambientais. A fase de fósforo particulado pode sedimentar junto ao fundo, e a partir daí por remobilização diagenética voltar para a fase dissolvida ou ser dissolvido localmente por bactérias. O fósforo particulado pode também ser dessorvido e voltar para a fase dissolvida, como pode ser observado na figura 4.

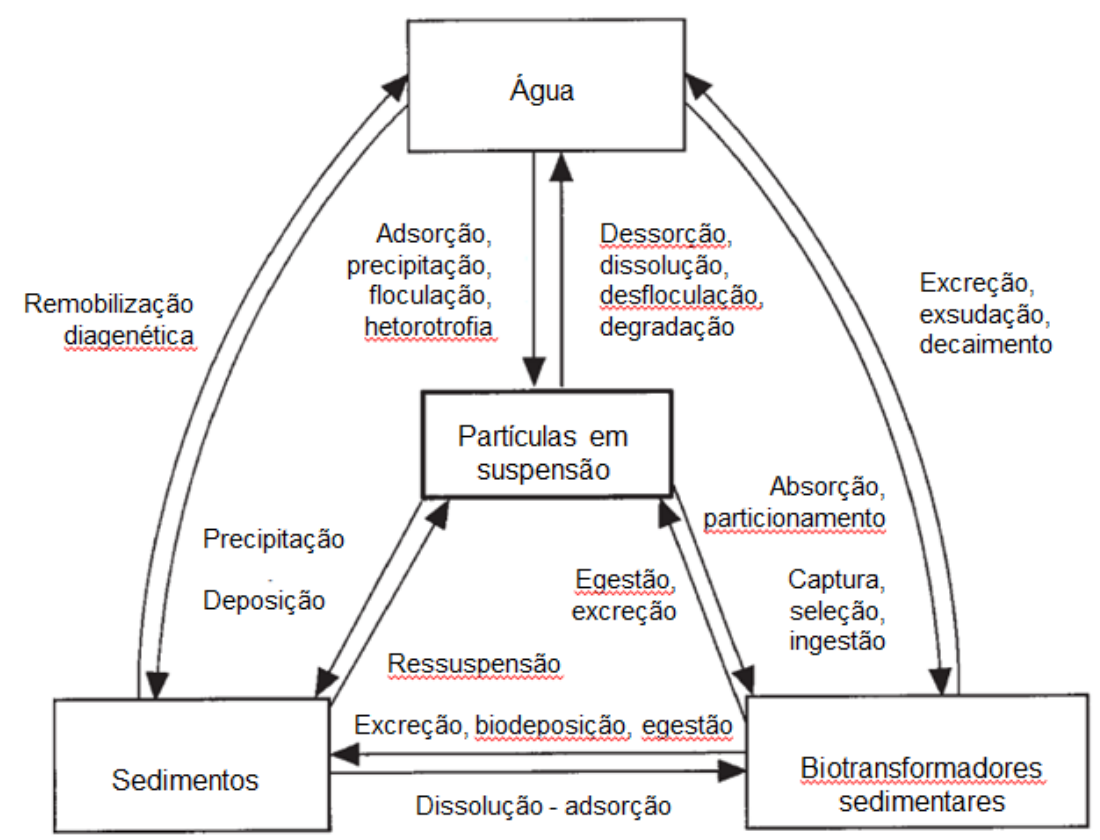

Figura 4. Representação esquemática do papel dos sedimentos em suspensão nos processos biogeoquímicos estuarinos e costeiros. As caixas representam os compartimentos que hospedam materiais e constituintes químicos e as setas denotam processos biogeoquímicos. Modificado de Turner \& Millward (2002). 
Assim, a interação do $P$ na coluna d'água com as formas particuladas em suspensão e com o sedimento, bem como, o excesso de P dissolvido podem indicar alterações ambientais e mesmo, o grau de impacto antrópico em uma região, sobretudo quando se observa o equilíbrio entre estas formas nos diferentes ambientes.

O grande aporte de fósforo pode ser proveniente de diversas origens, desde fontes naturais a antrópicas, como efluentes industriais, excesso de fertilizante, contribuição por esgotos até mesmo o aumento do processo erosivo na bacia de drenagem.

Em alguns casos, a coluna de água pode apresentar pequenas concentrações de fósforo dissolvido, apesar de receber uma grande carga deste nutriente, isso pode ser explicado pelos processos de remoção do mesmo, através da combinação de processos biogeoquímicos, como a adsorção-desorção com o sedimento e o material particulado em suspensão e a assimilação fotossintética em ambientes com disponibilidade de luz, são esses processos que controlam as concentrações de fosfato em rios e estuários (FROELICH, 1988).

Os processos de erosão provocados pelo desmatamento e ocupação do solo das zonas costeiras, podem alterar o aporte de P e Si tanto na forma dissolvida como na forma particulada para as vias hídricas chegando à zona costeira. Isto pode alterar a transparência da água e formar plumas de espalhamento que modificam os processos biogeoquímicos de outros elementos nos locais de aporte, além de ter reflexos na biogeociclagem dos elementos $\mathrm{P}$ e $\mathrm{Si}$ considerando os processos de ressuspensão, adsorção e incorporação biológica. Desta forma, na região de estudo o comportamento do silício, que também possui forte ligação com aportes de origem terrígena poderá auxiliar no diagnóstico das alterações ambientais ligadas ao fósforo, que estão ocorrendo nas imediações do sistema hídrico e suas consequências ambientais.

A transformação e o comportamento de mistura do $\mathrm{P}$ particulado pode desempenhar um papel importante no controle da distribuição, especiação e disponibilidade de espécies de $\mathrm{P}$ dissolvido em sistemas estuarinos. 


\subsection{Especiação de Fósforo Sedimentar}

O fósforo pode ser encontrado no sedimento nas seguintes formas: fósforo biodisponível ou fracamente ligado (P-bio), fósforo ligado a óxidos-hidróxidos de ferro ( $\mathrm{P}-\mathrm{Fe}$ ), fósforo ligado à apatita autigênica (P-CFAP), fósforo ligado à fluorapatita (P-FAP) e fósforo orgânico (P-org), a soma destas frações constitui o fósforo total sedimentar (P-T).

O fósforo biodisponível ou fracamente ligado (P-bio) é formado através da adsorção direta de fosfato (PID) para a superfície mineral dos sedimentos, que pode ocorrer devido ao gradiente de salinidade estuarino, a temperatura e a variação no pH (MENG et al., 2014).

O fósforo ligado a óxidos-hidróxidos de ferro ( $\mathrm{P}-\mathrm{Fe})$ é formado através da coprecipitação de fosfato aos óxidos e hidróxidos de ferro, sob condições ambientais favoráveis, como em condições redutoras em zonas subóxidas ou anóxicas (RUTTEMBERG, 1992). Um grande parcela do P-Fe é amorfo e não cristalino, isto indica que o $\mathrm{P}$ liberado de sedimentos estuarinos e de água doce são largamente controlados pela redução de $\mathrm{FeOOH}$ (BIANCHI, 2007).

A fase fósforo ligada à apatita autigênica (P-CFAP) ocorre em ambientes com condições aeróbicas, com pH entre 6-9 e com baixa concentração de cálcio $\left(1,0.10^{-3} \mathrm{M}\right)$ (SPIVAKOV, 1999). É composta por fósforo associado a carbonatos e fluorapatita autigênicos, apatita biogênica e carbonatos. Segundo Ruttenberg (2005), com relação ao P-CFAP ainda existem dúvidas sobre se ele é transportado fluvialmente ou removido da água do mar.

O fósforo ligado à fluorapatita (P-FAP) provém da intemperização de rochas ígneas e metamórficas que compõem a bacia de drenagem, sua presença pode indicar se o ambiente deposicional sofre ou já sofreu influência continental, marinho ou transicional (Ruttenberg, 1992).

O fósforo orgânico sedimentar ( $\mathrm{P}$-org) compreende parcela da estrutura do ATP, DNA, RNA, fosfolipídeos, fosfoprotrínas, fosfatases, ácidos húmicos, detritos orgânicos, entre outros componentes. 


\subsection{Fósforo e Impacto Ambiental}

Estimativas indicam que $70 \%$ da população mundial habita a zona costeira (BOUDOU, 2001). O impacto da alteração demográfica na população humana tem claramente prejudicado o ciclo biogeoquímico dos nutrientes nos estuários em geral. $O$ enriquecimento de nutrientes possivelmente é o problema mais difundido nos estuários ao longo do mundo (BIANCHI, 2007).

O Brasil ao longo do processo histórico de formação territorial, também sofre o processo de litorização da população, com aproximadamente $25 \%$ da população, cerca de 50,7 milhões de pessoas habitando a zona costeira (IBGE, 2011).

Modificações no uso e na ocupação do solo de uma bacia de drenagem influenciam diretamente a qualidade química das águas e sedimentos, devido a disposição inadequada de resíduos sólidos, o lançamento de cargas orgânicas e de efluentes domésticos, urbanos ou industriais. Em áreas rurais os nutrientes provenientes de fertilizantes podem ser lixiviados para o corpo hídrico (PAULAFILHO, 2012). De acordo com Caraco et al. (1993) em diversas áreas costeiras os altos valores de $\mathrm{P}$ estão associados à fonte antropogênica, em alguns casos a entrada de $\mathrm{P}$ é entre 10 e 100 vezes maior em relação ao período pré industrial. 


\section{Objetivo Geral}

Estudar as diferentes formas de fósforo ao longo de um sistema hídrico contíguo que apresenta múltiplos cenários, desde aquele sob alto grau de preservação até sob influência de impacto antrópico, observando o processo de ciclagem biogeoquímica do $\mathrm{P}$, considerando $\mathrm{o}$ equilíbrio entre suas formas dissolvidas e particuladas ao longo da coluna d'água e as especiações químicas nos sedimentos.

\subsection{Objetivos Específicos}

- Determinar as formas de P na coluna d'água nos diferentes setores do sistema estuarino associado aos dados hidrológicos e biogeoquímicos, de modo a estabelecer sua potencialidade de resposta às alterações que atingem os diferentes setores desse sistema contiguo.

- Quantificar e avaliar o comportamento de silicato dissolvido, de modo a relacionar ao comportamento biogeoquímico do $\mathrm{P}$, considerando suas similaridades de entrada e deposição no sistema hídrico via lixiviação terrestre e assimilação por organismos fitoplanctônicos.

-Quantificar a participação do material particulado em suspensão no ciclo biogeoquímico do fósforo, para verificar a contribuição do conteúdo de $\mathrm{P}$ associado a esse material nos diferentes setores do sistema.

- Fazer a associação do comportamento do P no sistema hídrico com os conteúdos observados nos sedimentos, considerando a especiação do fósforo sedimentar (P-bio, P-Fe, P-CFAP, P-FAP e P-org), para compreender o quadro recente de comportamento do $\mathrm{P}$ e o potencial de retenção/liberação para a coluna d’água e a origem do fósforo depositado nos diferentes setores estudados.

-Contribuir ao banco de dados regionais de biogeoquímica do $\mathrm{P}$ sob diferentes pressões ambientais. 


\section{3. Área de Estudo}

\subsection{Complexo Estuarino-Lagunar de Cananeia-Iguape (SP)}

Com temperatura média anual de $23,8^{\circ} \mathrm{C}$ e pluviosidade maior que $2200 \mathrm{~mm}$ (SILVA, 1989), esta região está sob influência da Zona de Convergência do Atlântico Sul (ZCAS), que no período do verão possui maior intensificação da massa de ar Tropical Atlântica, com a ação de instabilidades e ventos alísios, que carregam a umidade para o continente (GUEDES, 2009), formando ondas no sentido NE-E (MIRANDA et al., 2012). No inverno ocorre uma maior influência da massa de ar Polar, derrubando as temperaturas (GUEDES, 2009), o padrão de onda nesta época é de SE-S-SW (MIRANDA et al., 2012). Outros fatores climáticos são a ação das chuvas orográficas e a influência do sistema de monção da América do Sul, registrado por Cruz et al. (2007) em estudo realizado com isótopos estáveis de oxigênio em espeleotemas de Botuverá-SC desde os últimos 116 mil anos.

O sistema estuarino-lagunar de Cananeia-Iguape (SP) é regido pela entrada e saída da onda de maré dirigindo a circulação hidrodinâmica no sistema, misturando águas oceânicas e estuarinas. De acordo com Miranda et al. (2012) este sistema estuarino é classificado como parcialmente misturado e fracamente estratificado. Segundo Pisetta (2010), o Valo Grande comporta-se como uma zona de maré de rio.

Os principais rios contribuintes para o sistema estuarino-lagunar de Cananeia-Iguape (SP) são os rios: das Minas, Taquari, Mandira e Itapitangui, com foz no Mar de Cubatão; os rios Cordeiro e Sorocaba com foz na porção sul do Mar Pequeno; e o Rio Ribeira de Iguape, através do Valo Grande, tem sua foz no Mar Pequeno junto à cidade de Iguape (PISETTA, 2010).

\subsection{A Formação Geológica do complexo estuarino-lagunar de Cananeia- Iguape (SP)}

Atualmente existem três modelos de formação e evolução do sistema estuarino-lagunar de Cananeia-Iguape (SP), que ocorreu devido à deposição de sedimentos Quaternários formando a Ilha Comprida, considerada como uma ilha 
barreira, estes modelos foram propostos por: Geobrás (1966), Martin e Suguio (1978), Giannini et al. (2003 e 2009), Nascimento Jr et al. (2008) e Guedes (2009), os três últimos autores fazem parte do mesmo grupo de pesquisa e realizaram trabalhos com o mesmo viés de pensamento. Mesmo com diversas pesquisas realizadas na área este processo ainda não é bem compreendido.

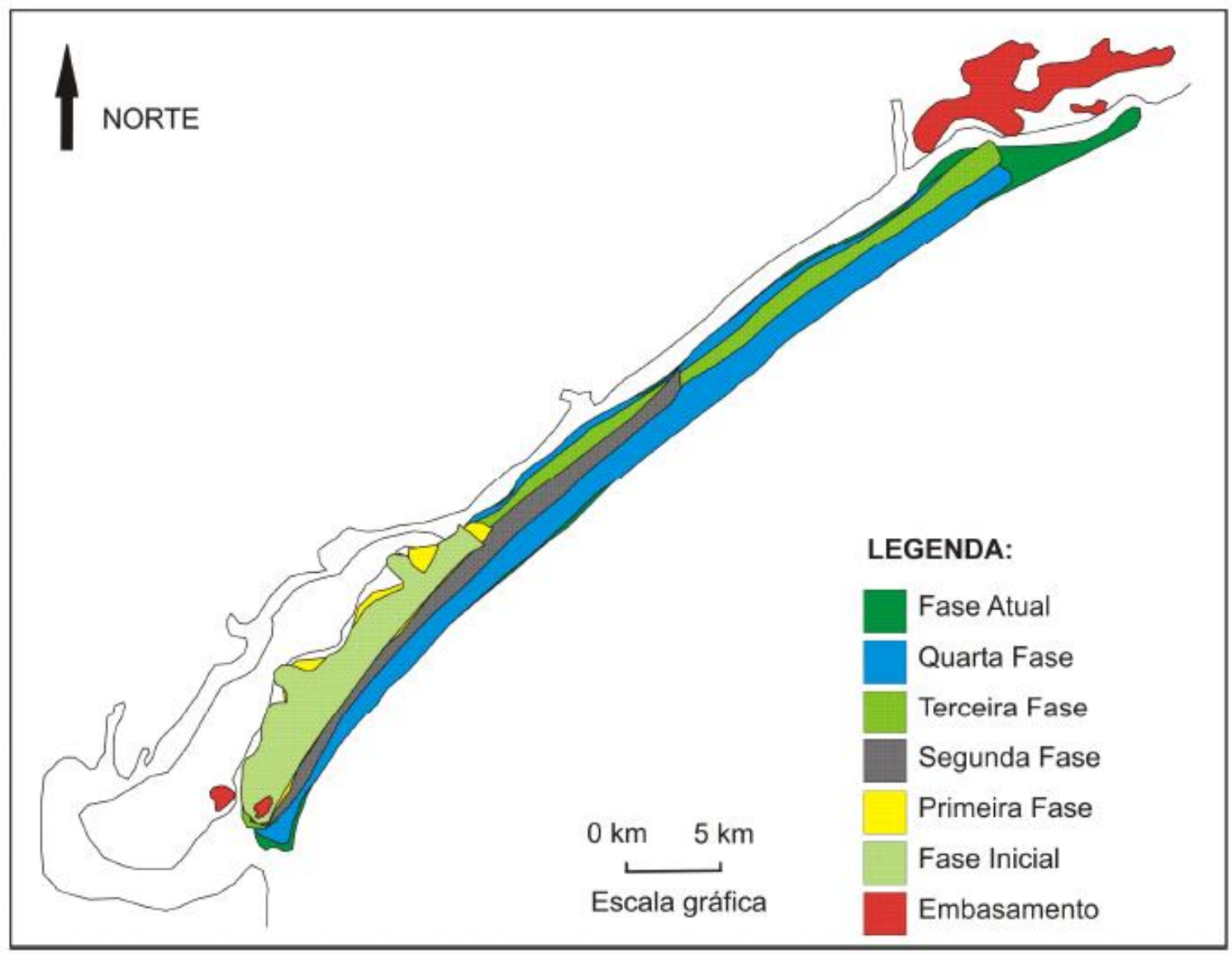

Figura 5. Modelo evolutivo da Ilha Comprida, proposto por Geobrás (1966). Fonte: Guedes (2009).

Neste modelo proposto por Geobrás os autores (Fig. 5), classificam a llha Comprida como uma ilha barreira com formação associada às variações relativas do nível do mar ocorridas durante o Quaternário e posterior evolução ocorrida durante o Holoceno, como apontado por Guedes (2009).

Baseando-se em fotografias aéreas Giannini $(2003,2009)$ propõe um modelo composto por quatro fases (Fig. 6) e uma possível fase zero: 
- Fase zero: possível formação da barreira transgressiva, porém esta etapa ainda necessita de maiores estudos;

- $1^{\circ}$ fase: crescimento da ilha para NE, adição de cordões litorâneos, componente de engorda pronunciada para NE;

- $2^{\circ}$ fase: crescimento acentuado para NE, com componente de engorda;

- $3^{\circ}$ fase: interrompimento do crescimento para NE, devido ao bloqueio pelo Morro de Icapara, prevalecimento da engorda neste momento;

- $4^{\circ}$ fase: a engorda da ilha ultrapassa a barreira, realizada pelo Morro de Icapara, fazendo com que a llha Comprida voltasse a crescer para NE. Este processo continua atuante.

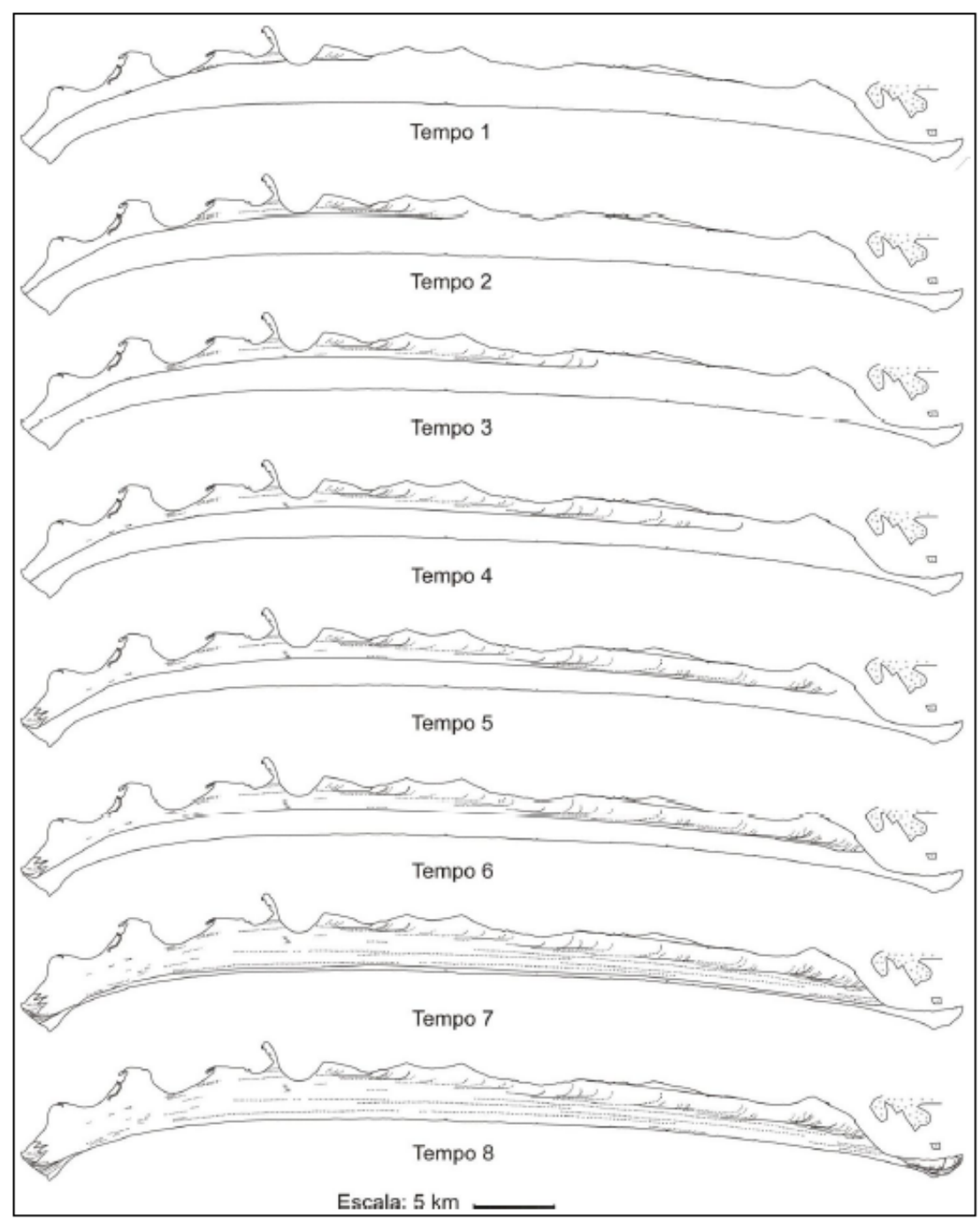

Figura 6. Modelo evolutivo da llha Comprida, proposto por Giannini et al. $(2003,2009)$. Tempo 1 a 3 correspondem a $1^{\circ}$ e $2^{\circ}$ fase, tempo 4 a 6 correspondem a $3^{\circ}$ fase e Tempo 8 a $4^{\circ}$ fase. Fonte: Guedes (2009). 
Em sua dissertação de mestrado Guedes (2009), realizou um trabalho detalhado e propôs um modelo evolutivo para a llha Comprida, esquematizado entre 6.000 e 1.900 anos A.P. (Antes do Presente) e 1.900 anos A.P. até o presente:

- De 6.000 a 1.900 anos A.P.

Segundo Guedes (2009), na época do surgimento da llha Comprida pode-se supor que sua formação se iniciou como uma ilha barreira transgressiva.

Após esta fase inicial até aproximadamente 5.000 anos A.P., a ilha apresentou fase de crescimento acelerado no sentido longitudinal e transversal, com a deposição de cristas praiais (GUEDES, 2009).

De 5.000 a aproximadamente 1.900 anos A.P., ocorreu uma fase de com menor taxa de crescimento longitudinal de 5,2 a $6,9 \mathrm{ma}^{-1}$ e de engorda transversal também (GUEDES, 2009).

- De 1.900 anos A.P. até o presente

A partir de 1.900 anos A.P., o crescimento longitudinal da ilha foi bloqueado pelo morro de Icapara e todo o sedimento foi utilizado para a fase progradacional em toda a ilha, com duração de aproximadamente 1.700 anos (Fig. 7a) (GUEDES, 2009).

O final da Pequena Idade do Gelo e a abertura do Valo Grande em 1852, favoreceram o crescimento da Ilha Comprida para NE. A ilha voltou a crescer longitudinalmente em uma taxa relativamente grande de 25 a $30 \mathrm{ma}^{-1}$, uma das influências do aporte de sedimentos fluviais para o sistema estuarino, que intensificou o meandramento do canal no setor $\mathrm{N}$, alterando de posição a Barra de Icapara (Fig. 7b) (GUEDES, 2009).

A partir principalmente de aproximadamente 150 anos A.P. as taxas de progradação foram altas nas extremidades da llha Comprida e retrogradação no centro-sul, local com manutenção das atividades das rupturas de deflação. 

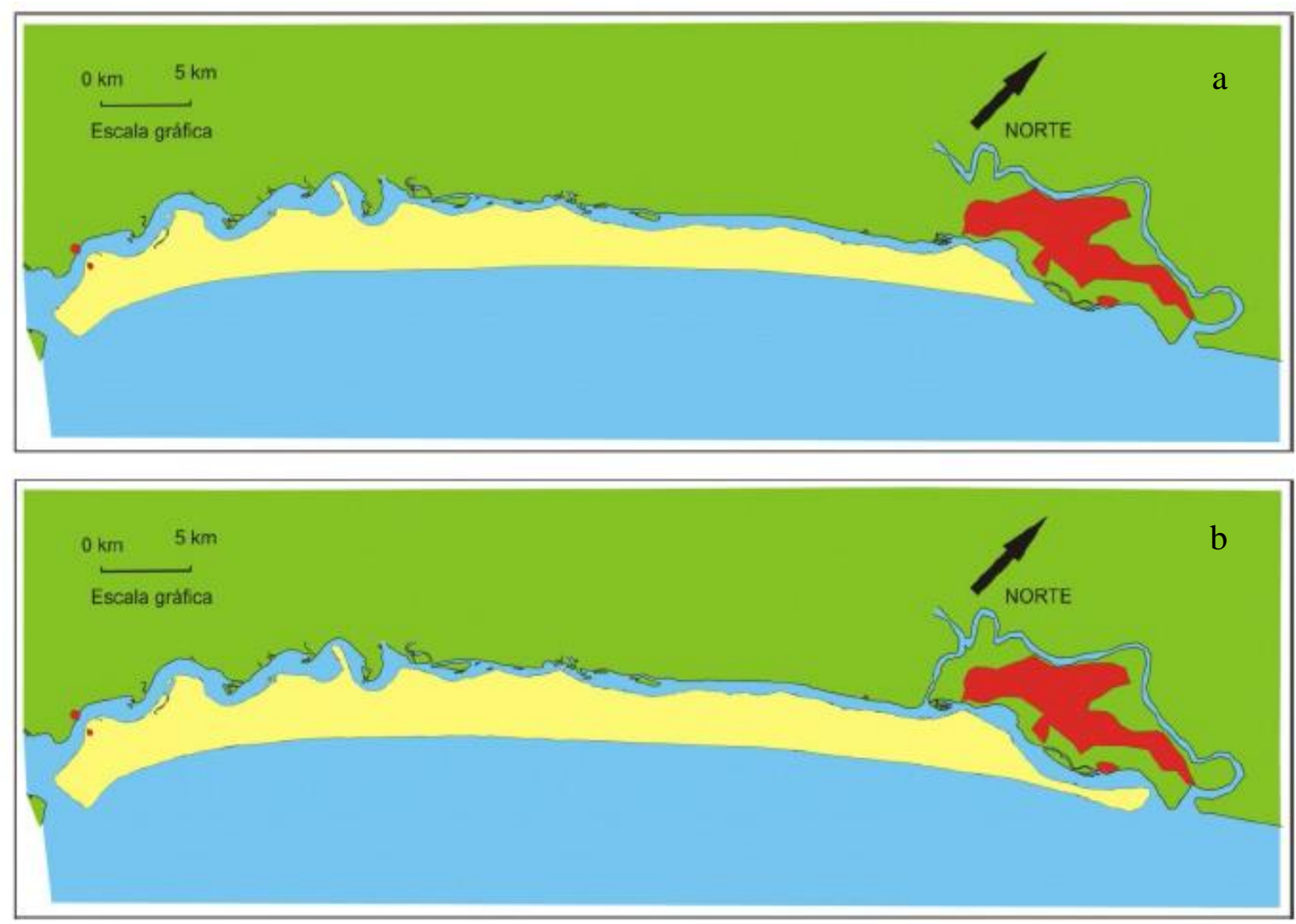

Figura 7. Evolução da llha Comprida de 1.900 anos A.P. até o presente. (A) final do período de bloqueio da componente longitudinal pelos morros perto de lguape (com duração aproximadamente 1.700 anos); (B) após a retomada do crescimento longitudinal (nos últimos 200 anos). Fonte: Guedes (2009).

\subsection{O Canal Artificial do Valo Grande}

$\mathrm{Na}$ região Norte do estuário de Cananeia-Iguape, na cidade de Iguape de 1827 a 1852 foi construído um canal artificial, com 4,4m de largura e $2 \mathrm{~m}$ de profundidade, entre o Rio Ribeira de Iguape e o Mar Pequeno, denominado Valo Grande, com a finalidade de escoar a produção agrícola do Vale do Ribeira para o Porto de Iguape com maior rapidez (TELEGINSKI, 1982).

A bacia hidrográfica do rio Ribeira de Iguape é uma das maiores do estado, com cerca de $24.980 \mathrm{~km}^{2}$ e uma vazão média de $508 \mathrm{~m}^{3} \mathrm{~s}^{-1}$ (SANTANA, 2008). Como uma tentativa de evitar o processo erosivo atuante em 1978 houve o fechamento do canal através de barramento, neste momento o mesmo já tinha cerca de $250 \mathrm{~m}$ de largura e $7 \mathrm{~m}$ de profundidade. Geobrás (1966), já apontava que o canal 
transportava $1.000 .000 \mathrm{~m}^{3}$ ano ${ }^{-1}$ de sedimentos finos em suspensão e $1.000 \mathrm{~m}^{3}$ ano${ }^{1}$ de material arenoso das margens erodidas do próprio canal. Em 1983, devido à ocorrência de grandes enchentes houve o rompimento da barragem, rapidamente reconstruída. Atualmente o canal encontra-se aberto desde o rompimento da última barragem em 1995, devido a grandes índices pluviométricos no verão.

O Valo Grande possibilita a entrada de água doce de forma mais direta para o Complexo Estuarino-Lagunar de Cananeia-Iguape formando uma nova foz, que insere materiais no sistema. Esta área tem sido atingida pela presença de excesso de nutrientes como o fosfato, o nitrato e o silicato. $O$ fósforo pode ser proveniente da fertilização, dos agrotóxicos oriundos de áreas de cultivo de banana próximas à rede de drenagem, da falta de tratamento de esgoto da região, da presença de mineradoras na bacia de drenagem e do processo erosivo atuante nas margens do Rio e no próprio canal. Além de nutrientes, o rio transporta para o sistema estuarino partículas, que alteraram drasticamente as características do aporte sedimentar, levando ao assoreamento do Mar Pequeno (SOUSA, 2013).

Uma das possíveis fontes de inserção de fósforo no complexo estuarino pode ocorrer através do rio Jacurpiranga, um afluente do rio Ribeira de Iguape. $\mathrm{Na}$ cidade de Cajati (SP), por onde o rio Jacupiranga flui, desde 1940 está instalado um complexo industrial integrado que atua na produção de: rocha fosfática, calcário para cimento e calcário agrícola, cimento, ácido sulfúrico, ácido fosfórico, superfosfato simples e fosfato bicálcico.

De acordo com os modelos propostos por Giannini et al. (2003; 2009), Nascimento Jr et al. (2008) e Guedes (2009), o último estágio de evolução da llha Comprida, a variação da linha de costa com o crescimento da ilha para NE e o deslocamento da Barra de Icapara, ocorreu devido ao incremento de sedimentos lamosos provenientes do rio Ribeira de Iguape via Valo Grande (TELES, 1997). Além disso, esta carga de materiais acarretou em um intenso processo de assoreamento da Barra de Icapara, aumento do número e tamanho das ilhas próximas à desembocadura do Valo, estreitamento do canal principal do sistema estuarino e anexação de algumas ilhas às margens do canal (FREITAS et al., 2006). O local em que a água do rio deságua no estuário está formando um "delta intralagunar antropogênico" segundo Italiani et al. (2010). 
Alguns autores (DAEE, 1989; BRAGA et al., 2000; ESCHRIQUE, 2011; BERBEL, 2008; BARRERA-ALBA et al., 2009; MAHIQUES et al., 2009; MALUF, 2009; COELHO, 2011; BASTOS, 2014; AGOSTINHO, 2015) vem mostrando que nas proximidades do Valo Grande o complexo vêm sofrendo grandes alterações na salinidade, no aporte de nutrientes ( $\mathrm{N}, \mathrm{P}, \mathrm{Si})$ na qualidade do sedimento transportado, na própria paisagem (mudança na vegetação), que levou ao aumento de material particulado em suspensão, ao aumento da inserção de fósforo e silício. As alterações ambientais que ocorreram causaram uma modificação na flora e fauna locais que influenciam o modo de subsistência das comunidades caiçaras da região, principalmente na arte da pesca (OLIVEIRA, 2011). 


\section{Material e Métodos}

\subsection{Amostragem}

Foram realizadas duas campanhas de coleta de amostras de água e sedimentos no Complexo Estuarino-Lagunar de Cananeia-Iguape (SP), uma no inverno/2014 e outra no período de outono/2015. A primeira campanha foi realizada de 18 a 29 de agosto de 2014 e a segunda de 20 a 22 de maio de 2015. A bordo das embarcações de pesquisa B./Pq. Albacora, nas estações internas ao sistema, e a embarcação B./Pq. Alpha Delphini, para as coletas na plataforma continental, do Instituto Oceanográfico da Universidade de São Paulo.

Na campanha de agosto de 2014, foram realizadas no total 20 estações de coleta, distribuídas entre: o rio Ribeira de Iguape (R1-R5), sistema estuarino-lagunar de Cananeia-Iguape (1-11), Barra de Icapara (Ml1-MI5) e Barra de Cananeia (MC1MC5). No entanto na campanha de maio de 2015, foram realizadas 19 estações de coleta, distribuídas entre: o rio Ribeira de Iguape (Registro, R0-R6), rio Guaraú (estação Cajati), córrego Vale (estação Vale na cidade de Cajati) e sistema estuarino-lagunar de Cananeia-Iguape (1-11). Na figura 8, observa-se a localização das estações de coleta.

Para a coleta das amostras de água, foram utilizadas garrafas coletoras do tipo Van Dorn e Nansen Hydrobios $\AA$ e para os sedimentos, pegadores de fundo tipo van Veen. As alíquotas para as análises físicas e químicas foram separadas para filtração e análise em laboratório, os sedimentos foram coletados em sacos plásticos e em frascos de plástico, ambos previamente limpos em banho de $\mathrm{HCl} 3 \mathrm{M}$ e secos. Até o momento da análise o material foi acondicionado e mantido congelado a $20^{\circ} \mathrm{C}$. 


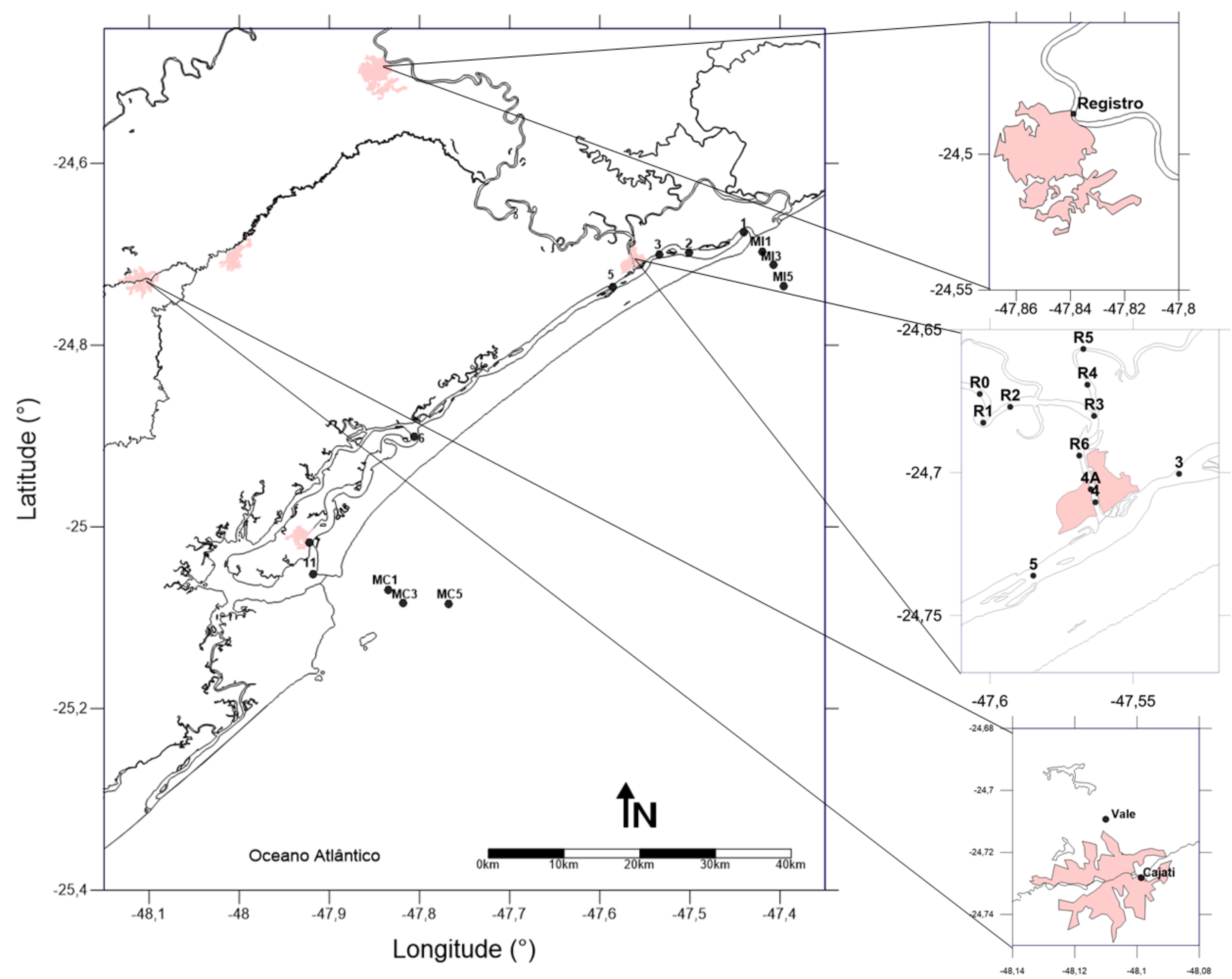

Figura 8. Localização das estações de coleta de água e sedimento na região do complexo estuarino-lagunar de Cananeia-lguape (SP). 


\subsection{Climatologia e Maré}

Os dados climatológicos utilizados foram obtidos no Centro Integrado de Informações Agrometeorológicas (CIIAGRO), através do site www.ciiagro.sp.gov.br.

As informações para a confecção da curva de maré foram fornecidas pelo Instituto Oceanográfico, através do site www.mares.io.usp.br/tabua/.

\subsection{Hidrografia e Biogeoquímica na Coluna d'água}

\subsubsection{Temperatura da água}

A temperatura da água in situ foi medida utilizando-se termômetros de reversão protegidos, calibrados em graus Celsius e acondicionados em cartuchos contendo termômetros auxiliares, acoplados a garrafa tipo Nansen Hydrobios ${ }^{\circledR}$, com precisão de $\pm 0,02{ }^{\circ} \mathrm{C}$.

\subsubsection{Salinidade}

A amostra de água para determinação da salinidade foi coletada em garrafa Van Dorn com frasco de vidro âmbar. A determinação foi realizada no Laboratório de Biogeoquímica de Nutrientes, Micronutrientes e Traços nos Oceanos (LABNUT- IO - USP) de acordo com método indutivo com o auxílio de um salinômetro marca Beckman, RS10, com precisão de $\pm 0,005$, com unidades apresentadas em unidade de salinidade prática (USP).

\subsubsection{Potencial Hidrogeniônico (pH)}

As amostras para a análise de $\mathrm{pH}$ foram coletadas da garrafa tipo Nansen Hydrobios ${ }^{\circledR}$ e analisadas no laboratório da Base de Pesquisa Dr. João Paiva de Carvalho do IO-USP, com o auxílio do pHmetro Orion P210A, precisão de $\pm 0,001$, seguindo as recomendações de Aminot e Chaussepied (1983). 


\subsubsection{Oxigênio Dissolvido (OD)}

As amostras foram coletadas da garrafa tipo Nansen Hydrobios ${ }^{\circledR}$. A determinação foi realizada no laboratório da Base de Pesquisa Dr. João Paiva de Carvalho, do IO-USP, de acordo com metodologia proposta por Winkler (1888), como apresentada por Grasshoff et al. (1983), utilizando um titulador Metrohm automático, com precisão de $\pm 0,02 \mathrm{~mL} \mathrm{~L}^{-1}$ para teores de $2 \mathrm{~mL} \mathrm{~L}^{-1} \mathrm{e}$ $\pm 0,04 \mathrm{~mL} \mathrm{~L}^{-1}$ para teores superiores.

\subsubsection{Turbidez}

A amostra de água para a analise de turbidez foi coletada na garrafa Nansen Hydrobios ${ }^{\circledR}$. A medida foi realizada in situ através do turbidímetro

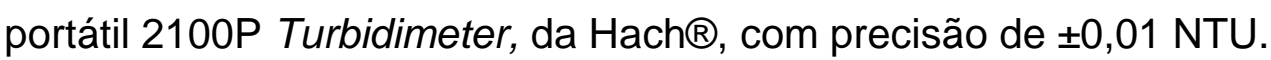

\subsubsection{Silício Inorgânico Dissolvido}

Para a determinação dos nutrientes principais fósforo, silício e também do material particulado em suspensão (MPS), foi retirada uma amostra de água da garrafa tipo Van Dorn em um frasco de plástico de $2 \mathrm{~L}$, acondicionado ao abrigo da luz e mantido sobre refrigeração $\left(-4,0^{\circ} \mathrm{C}\right)$ até o momento da filtração. Em laboratório, junto a Base de Pesquisa Dr. João Paiva de Carvalho IO-USP, em Cananeia, procedeu-se a filtração em filtros de fibra de vidro de porosidade nominal de $0,45 \mu \mathrm{m}$ da marca GF/F da marca Whatman ${ }^{\circledR}$, para separar a fração dissolvida (menor que $0,45 \mu \mathrm{m}$ ) e a particulada (maior que $0,45 \mu \mathrm{m}$ ).

Os teores de silicato dissolvido nas amostras de água foram determinados, no LABNUT, segundo o método colorimétrico descrito por Grasshoff et al. (1983), com absorbância medida em 810 nm, utilizando espectrofotômetro SP-22 da Bioespectro ${ }^{\circledR}$. O limite de detecção do método, em cubetas de $1 \mathrm{~cm}$ de trajeto óptico, é de $0,01 \mu \mathrm{mol} \mathrm{L^{-1 }}$, precisão do método é de $\pm 0,01 \mu \mathrm{mol} \mathrm{L}{ }^{-1}$.

\subsubsection{Fósforo Inorgânico Dissolvido (PID)}

A determinação do fosfato dissolvido foi realizada no LABNUT, baseada no método colorimétrico descrito por Grasshoff et al. (1983), a absorbância das amostras foram lidas em 880 nm, utilizando espectrofotômetro 
SP-22 da Bioespectro®. O limite de detecção do método, em cubetas de $5 \mathrm{~cm}$ de trajeto óptico, é de $0,01 \mu \mathrm{mol} \mathrm{L}{ }^{-1}$, precisão do método $\pm 0,01 \mu \mathrm{mol} \mathrm{L}^{-1}$.

\subsubsection{Fósforo Orgânico Dissolvido (POD) e Fósforo Total Dissolvido (PTD)}

A determinação destes parâmetros foi realizada no LABNUT onde as amostras foram foto-oxidadas com lâmpada UV e adição de peróxido de hidrogênio de acordo com Armstrong et al. (1968), Armstrong e Tibbits (1968) e Saraiva (2003). Após a oxidação foi realizada a determinação do fosfato segundo as recomendações de Grasshoff et al. (1983), obteve-se assim o PTD.

O fósforo orgânico dissolvido foi calculado de acordo com a relação $P O D=P T D-P I D$.

\subsubsection{Material Particulado em Suspensão (MPS) e Material Particulado Orgânico em Suspensão (MPOS)}

As determinações do material particulado em suspensão e do material orgânico particulado em suspensão foram realizadas no LABNUT, segundo o método proposto por Strickland e Parsons (1968), utilizando com filtros de fibra de vidro de porosidade nominal de $0,45 \mu \mathrm{m}$ da marca GF/F Whatman ${ }^{\circledR}$, prépesados em balança Bel Engineering ${ }^{\circledR}$, modelo MARK $210 \mathrm{~A}$, com precisão de $\pm 0,0001 \mathrm{~g}$. Os valores finais de MPS foram expressos em $\mathrm{mg} \mathrm{L}^{-1}$, seguindo a fórmula apresentada por Grasshoff et al. (1983) e Aminot e Chaussepied (1983).

\subsubsection{Fósforo no Material Particulado em Suspensão}

$\mathrm{Na}$ fração particulada em suspensão foram determinados o fósforo orgânico (POP), inorgânico (PIP) e total (PPT), baseado em Aspila et al. (1976) com adaptações apresentadas em Coelho (2011).

Para estas determinações as amostras de água foram filtradas na Base de Pesquisa Dr. João Paiva de Carvalho em filtros de fibra de vidro com porosidade nominal de $0,45 \mu \mathrm{m}$ GF/F Whatman $\AA$, previamente calcinados, a $450^{\circ} \mathrm{C}$ durante 4 horas, e pesados em balança Bel Engineering $\Theta$, modelo MARK 210A, com precisão de $\pm 0,0001 \mathrm{~g}$. O filtro com material foi 
acondicionado em tudo falcon de $15 \mathrm{~mL}$ e levado ao freezer $\left(-20^{\circ} \mathrm{C}\right)$ até 0 momento da análise no LABNUT.

Para a análise do PIP, adicionou-se $10 \mathrm{~mL}$ de $\mathrm{HCl} 1 \mathrm{~mol} \mathrm{~L}^{-1}$, seguido de agitação a 300 rpm durante 16 horas. O extrato foi diluído 10 vezes e o fosfato foi lido de acordo com as especificações de Grasshoff et al. (1983).

Para a extração do PTP, foi calcinado um segundo filtro a $530^{\circ} \mathrm{C}$ durante $1 \mathrm{~h} 30$, transferida para tubos falcon, adicionou-se $10 \mathrm{~mL}$ de $\mathrm{HCl} 1 \mathrm{~mol} \mathrm{~L}^{-}$ 1, o extrato foi diluído 10 vezes e o fosfato foi lido de acordo com as especificações de Grasshoff et al. (1983), assim se obteve o fósforo total particulado. Por diferença de massa foi calculado o PPO, ou seja, PPO= PPTPIP.

\subsubsection{Clorofila-a}

A coleta de água para a determinação de clorofila foi realizada utilizando-se garrafa de Van Dorn. A amostra foi coletada em frasco plástico e preservada ao abrigo da luz a $-4^{\circ} \mathrm{C}$ até o momento da filtração. A filtração foi realizada utilizando-se filtro de fibra de vidro com porosidade nominal de 0,45 $\mu \mathrm{m}$ da marca Sartorius ${ }^{\circledR}$ na Base de Pesquisa Dr. João Paiva de Carvalho, a determinação foi realizada via extração da clorofila em acetona 90\%, de acordo com as especificações de Strickland e Parsons (1968) no LABNUT.

\subsection{Parâmetros Sedimentares}

\subsubsection{Granulometria, Matéria Orgânica (MO) e Carbonato Biodetrítico}

As determinações: do teor de matéria orgânica, de carbonato biodetrítico e das frações granulométricas foram realizadas de acordo com as especificações de Suguio (1973). Anteriormente as amostras foram secas a frio utilizando-se liofilizador, marca LIOBRÁS ${ }^{\circledR}$ modelo L101 e esboroadas para a homogeneização. Todas as análises sedimentares foram realizadas no LABNUT.

Para a mensuração do teor de matéria orgânica foi pesada uma alíquota de $30,0 \mathrm{~g}$ de sedimento na balança Bel Engineering ${ }^{\circledR}$, modelo MARK $210 \mathrm{~A}$, com precisão de $\pm 0,01 \mathrm{~g}$. A amostra foi submetida a ataque de peróxido de hidrogênio $10 \%$ em mesa aquecedora da marca Ethiktechnology®, modelo 
208D, durante cerca de 20 horas, seguida de lavagem com água Milli-Q, seca em estufa, resfriada no dessecador e pesada novamente.

Para a determinação dos teores de carbonato biodetrítico a amostra foi submetida a ataque de solução de $\mathrm{HCl} 10 \%$ durante 12 horas, seguida de lavagem com água Milli-Q, seca em estufa, resfriada no dessecador e pesada novamente, como descrito em Ingram (1971).

A determinação granulométrica foi processada de acordo com o método proposto por Suguio (1973). O material grosseiro (areia) foi separado utilizando-se um jogo de peneiras da marca GRANULOTEST® com malhas de $2 \mathrm{~mm}$ a $63 \mathrm{~mm}$, com intervalos de 0,5. O material fino (silte e argila) foi colocado em suspensão em proveta com água destilada e $1 \mathrm{~g}$ de pirofosfato de sódio, após o período pré-estabelecido foi pipetada uma alíquota que contém silte+argila e outra que contém argila, este método baseia-se nos princípios da Lei de Stokes.

\subsubsection{Extração Sequencial de Fósforo no Sedimento - SEDEX (P- bio; P-Fe; P-CFAP; P-FAP, P-org)}

Para a extração sequencial de fósforo no sedimento foi utilizado método de extração sequencial (SEDEX) segundo Ruttenberg (1992) com modificações propostas por Huerta-Diaz et al. (2005). Neste método de determinação foram realizadas cinco extrações para obtenção das seguintes frações: fósforo biodisponível ou fracamente ligado (P-bio), fósforo ligado à oxihidróxidos de ferro (P-Fe), fósforo ligado à apatita biogênica, carbonato fluorapatita e $\mathrm{P}$ adsorvido a $\mathrm{CaCO}_{3}$ (P-CFAP), fósforo ligado à fluoropatita de origem litogênica (P-FAP) e fósforo inorgânico (P-org). As leituras de fosfato finais seguiram as recomendações de Grasshoff et al. (1983). Para melhor adequação dos procedimentos, foi gerado um protocolo analítico apresentado na figura 9. 


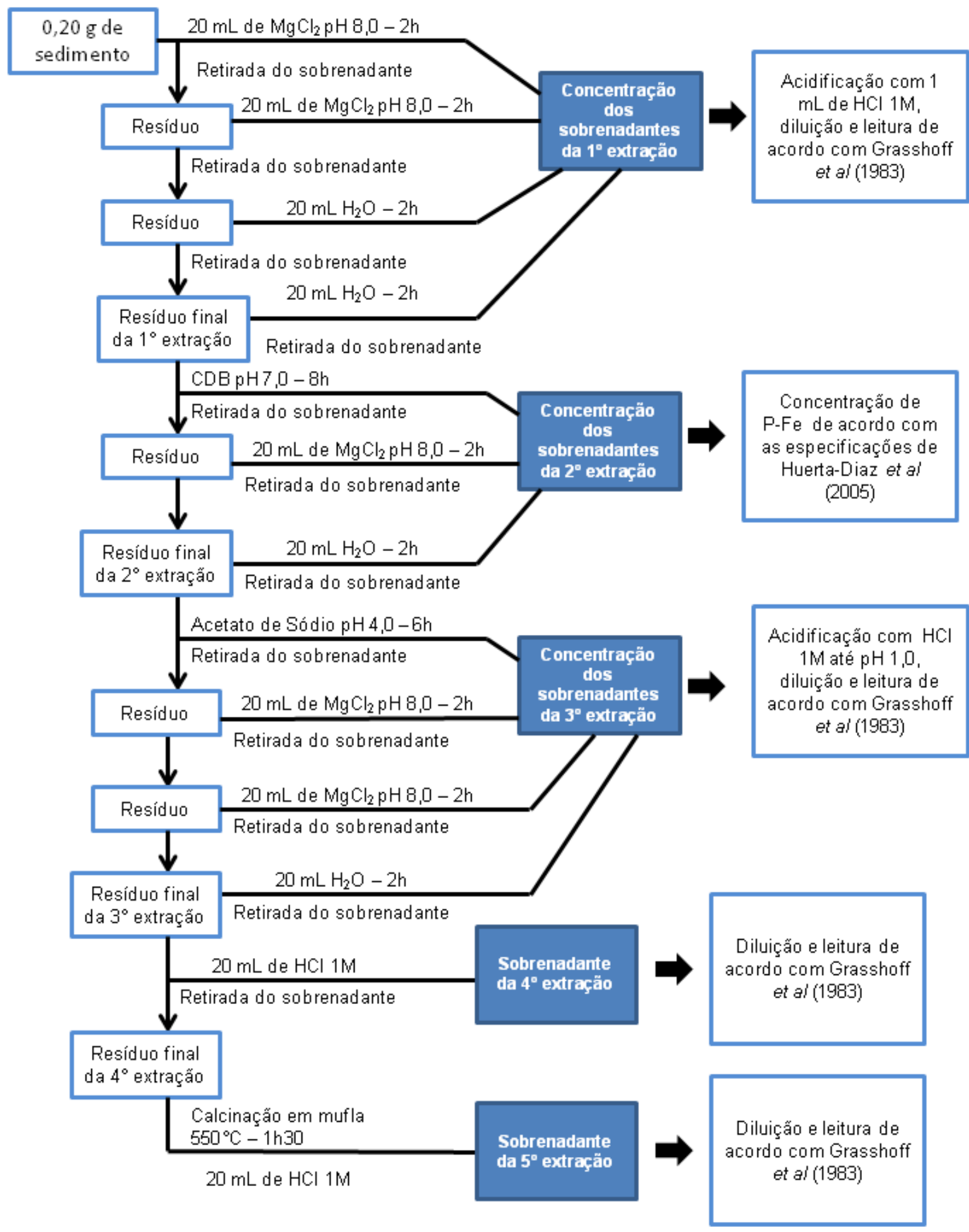

Figura 9. Fluxograma da análise SEDEX. Adaptado de Ruttenberg (1992) e Huerta-Diaz et al. (2005).

A extração do fósforo biodisponível ou fracamente ligado (P-bio) (primeira extração) foi realizada com a adição de $\mathrm{MgCl}_{2}$ em $\mathrm{pH}$ 8,0 para a 
formação do complexo $\mathrm{MgPO}_{4}^{-}$, seguido de 8 horas de agitação em mesa agitadora da marca Nova Ética ${ }^{\circledR}$, Kline modelo108 A. É necessário após esta etapa acidificar a amostra até o $\mathrm{pH} 1,0$, para quebra do complexo formado e realizar a determinação de fosfato liberado segundo as especificações de Grasshoff et al. (1983).

A extração do fósforo ligado à oxi-hidróxidos de ferro ( $\mathrm{P}-\mathrm{Fe})$ (segunda extração) foi realizada a partir do resíduo da etapa anterior, adicionando-se solução de citrato de sódio $0,22 \mathrm{M}$, ditionito de sódio $0,13 \mathrm{M}$ e bicarbonato de sódio $0,11 \mathrm{M}$ para a redução do $\mathrm{Fe}^{3+} \mathrm{em} \mathrm{Fe}{ }^{2+}$, seguida de agitação em mesa agitadora durante 10 horas. Após este período foi necessário pré-concentrar a amostra, separando-se uma alíquota de $10 \mathrm{~mL}$ com adição de $0,5 \mathrm{~mL}$ de solução de hidróxido de sódio $10 \mathrm{M}$ e lavagem com amônia líquida segundo as especificações de Huerta-Diaz et al. (2005). Para a leitura desta etapa como descrito na publicação de Huerta-Diaz et al. (2005) não se obteve resultados lineares na curva de calibração, portanto foram realizados diversos testes resultando na seguinte adaptação: de posse da solução extratora os reagentes foram adicionados na seguinte ordem: $1 \mathrm{~mL}$ de solução redutora (metabissulfito de sódio + citrato de sódio + tiossulfato de sódio), seguida de 1 $\mathrm{mL}$ de R2 (solução de ácido ascórbico) de fosfato de acordo com as especificações de Grasshoff et al. (1983), após espera de 5 minutos adicionouse $1 \mathrm{~mL}$ de R1(solução contendo ácido sulfúrico + heptamolibdato de amônio tetra-hidratado + antimoniltartarato de potássio) (GRASSHOFF et al., 1983). Após a adição dos reagentes as amostras foram colocadas na estufa a $40^{\circ} \mathrm{C}$, permanecendo na estufa durante 6 horas. Seguida de leitura em espectrofotômetro com comprimento de onda em $880 \mathrm{~nm}$.

A terceira extração, realizada a partir do resíduo da anterior, é a do fósforo ligado à apatita biogênica, carbonato fluorapatita e $\mathrm{P}$ adsorvido a $\mathrm{CaCO}_{3}$ (P-CFAP). Foi adicionado acetado de sódio em $\mathrm{pH} 4,0$, seguido de agitação em mesa agitadora durante 12 horas. Para a leitura foi necessário acidular a amostra a $\mathrm{pH}$ 1,0 para quebra de composto formado e o fosfato liberado será lido segundo as especificações de Grasshoff et al. (1983).

A quarta extração, realizada a partir do resíduo da anterior, forneceu o fósforo ligado à fluorapatita de origem litogênica (P-FAP), através de dissolução 
com adição de solução de $\mathrm{HCl} 1 \mathrm{M}$, seguida de agitação durante 16 horas. $\mathrm{O}$ sobrenadante foi diluído em 10 vezes com água milli-Q, seguido de determinação de fosfato segundo as especificações de Grasshoff et al. (1983).

A extração do fósforo orgânico (P-org) (quinta extração), foi realizada através da calcinação, do resíduo final, em mufla $550^{\circ} \mathrm{C}$ por $1 \mathrm{~h} 30$, seguido de adição de solução de $\mathrm{HCl} 1 \mathrm{M}$ e agitação em mesa agitadora durante 16 horas. O sobrenadante foi diluído em água milli-Q, seguido da determinação de fosfato segundo as especificações de Grasshoff et al. (1983).

\subsubsection{Fósforo Total no Sedimento (P-T)}

Neste trabalho o fósforo total no sedimento foi calculado de acordo com a soma das frações P-bio, P-Fe, P-CFAP, P-FAP e P-org, determinadas através da extração sequencial segundo Ruttenberg (1992) e Huerta-Diaz et al. (2005).

\subsection{Validação da análise de Extração Sequencial do Fósforo no Sedimento (SEDEX)}

A validação da metodologia, neste trabalho foi realizada para a verificação do desempenho do sistema analítico empregado na determinação de fósforo no sedimento para a análise Extração Sequencial do Fósforo no Sedimento (SEDEX) proposto por Ruttenberg (1992) e a leitura da fase P-Fe de acordo com as especificações de Huerta-Diaz et al. (2005) através do método CDB MAGIC.

\subsubsection{Limite de Detecção (LD)}

Segundo INMETRO (2010), o limite de detecção do método corresponde à concentração mínima de uma substância medida com $95 \%$ ou $99 \%$ de confiança de que a concentração do analito é menor que zero, e é expressa segundo a equação:

$$
L D=X_{b}+t^{*} S_{b}
$$

Onde: 
LD = Limite de Detecção;

$\mathrm{X}_{\mathrm{b}}=$ Média dos brancos das réplicas, realizadas para cada etapa da extração sequencial;

$\mathrm{t}=$ Fator numérico constante, $\mathrm{t}$ Student igual a 3,143, para amostras com $99 \%$ de confiança;

$\mathrm{S}_{\mathrm{b}}=$ Desvio padrão dos brancos.

\subsubsection{Erro Relativo (ER)}

O erro relativo (ER) foi calculado de acordo com as especificações de INMETRO (2010), a fim de verificar a eficiência de extração da especiação de fósforo no sedimento segundo as especificações de Ruttbemberg (1992) e . Para estas análises não existem Material Certificado de Referência (MCR) que abranja as cinco fases (P-bio, P-Fe, P-CFAP, P-FAP e P-Org) de fósforo no sedimento, para tanto se utilizou neste trabalho o MCR para sedimentos marinhos MESS-3 da National Research Council Canada, que possui 37,20 $\mu \mathrm{mol} \mathrm{g}^{-1}$ de fósforo total (P-T). Este cálculo é realizado através da equação 2 :

$$
E R=\underline{X}_{l_{\text {ab }}}-\underline{X}_{X_{v}}{ }^{*}{ }^{*} 100
$$

Onde:

$\mathrm{ER}=$ Erro Relativo;

$\mathrm{X}_{\mathrm{lab}}=$ Valor obtido experimentalmente ou média aritmética de valores obtidos;

$\mathrm{X}_{\mathrm{v}}=$ valor aceito como verdadeiro (valor certificado do MCR).

\subsubsection{Resultados para a análise de Extração Sequencial do Fósforo no Sedimento (SEDEX)}

Neste trabalho foram analisadas 7 alíquotas de brancos para a determinação do LD (Tab. 1), para cada fase de extração de fósforo no 
sedimento. Para as análises das fases P-bio, P-CFAP, P-FAP e P-org, foram utilizadas as especificações segundo Ruttenberg (1992), no entanto para a fase P-Fe foi utilizada a metodologia de acordo com Huerta-Diaz et al. (2005).

Tabela 1. Limites de Detecção das fases da extração sequencial do fósforo no sedimento.

\begin{tabular}{cccccc}
\hline & $\begin{array}{c}\text { P-bio } \\
\left.(\mu \mathrm{mol} \mathrm{g})^{-1}\right)\end{array}$ & $\begin{array}{c}\text { P-Fe } \\
\left(\mu \mathrm{mol} \mathrm{g}^{-1}\right)\end{array}$ & $\begin{array}{c}\text { P-CFAP } \\
\left(\mu \mathrm{mol} \mathrm{g}^{-1}\right)\end{array}$ & $\begin{array}{c}\text { P-FAP } \\
\left(\mu \mathrm{mol} \mathrm{g}^{-1}\right)\end{array}$ & $\begin{array}{c}\text { P-Org } \\
\left(\mu \mathrm{mol} \mathrm{g}^{-1}\right)\end{array}$ \\
\hline LD & 0,09 & 0,37 & 0,05 & 0,07 & 0,03 \\
\hline
\end{tabular}

$\mathrm{Na}$ tabela 2, observam-se os valores das frações de $\mathrm{P}$ em ensaios realizados com 4 alíquotas do material certificado de referência MESS-3.

Tabela 2. Especiação sedimentar do fósforo através do MCR MESS-3 pelo método SEDEX (Ruttenberg, 1992) e CDB-MAGIC (Huerta Diaz et al., 2005)

\begin{tabular}{|c|c|c|c|c|c|c|}
\hline & $\begin{array}{c}\text { P-bio } \\
\left.(\mu \mathrm{mol} \mathrm{g})^{-1}\right)\end{array}$ & $\begin{array}{c}\text { P-Fe } \\
\left.(\mu \mathrm{mol} \mathrm{g})^{-1}\right)\end{array}$ & $\begin{array}{c}\text { P-CFAP } \\
\left(\mu \mathrm{mol} \mathrm{g}{ }^{-1}\right)\end{array}$ & $\begin{array}{c}\text { P-FAP } \\
\left(\mu \mathrm{mol} \mathrm{g}{ }^{-1}\right)\end{array}$ & $\begin{array}{c}\text { P-Org } \\
\left.(\mu \mathrm{mol} \mathrm{g})^{-1}\right)\end{array}$ & $\begin{array}{c}\text { P-T } \\
\left.(\mu \mathrm{mol} \mathrm{g})^{-1}\right)\end{array}$ \\
\hline MESS 1 & 1,25 & 13,86 & 5,07 & 8,90 & 3,85 & 32,92 \\
\hline MESS 2 & 1,33 & 13,88 & 5,88 & 9,38 & 3,07 & 33,54 \\
\hline MESS 3 & 1,60 & 13,44 & 4,848 & 9,48 & 3,82 & 33,19 \\
\hline MESS 4 & 1,53 & 14,07 & 4,613 & 9,84 & 3,84 & 33,90 \\
\hline $\begin{array}{l}\text { Média } \\
\text { Desvio }\end{array}$ & 1,43 & 13,81 & 5,10 & 9,40 & 3,64 & 33,39 \\
\hline Padrão & $\pm 0,16$ & $\pm 0,26$ & $\pm 0,55$ & $\pm 0,38$ & $\pm 0,38$ & $\pm 0,42$ \\
\hline
\end{tabular}

A partir dos valores da tabela 2, foi calculada a eficiência do método foi de acordo com o erro relativo, como pode ser observado na tabela 3. Segundo Vink et al. (1997) na somatória para a composição do P-T, pode ocorrer diferenças devido a fração residual que é provavelmente composta por $P$ associado a argilominerais que não são extraídos pelo processo. 
Tabela 3. Eficiência da extração de P sedimentar pelo método SEDEX (Ruttenberg, 1992) e CDB-MAGIC (Huerta Diaz et al., 2005)

\begin{tabular}{ccc}
\hline & $\begin{array}{c}\text { Erro } \\
\text { Relativo }\end{array}$ & $\begin{array}{c}\text { \% de } \\
\text { Recuperação }\end{array}$ \\
\hline Padrão 1 & $11,50 \%$ & $88,50 \%$ \\
Padrão 2 & $9,85 \%$ & $90,15 \%$ \\
Padrão 3 & $10,78 \%$ & $89,22 \%$ \\
Padrão 4 & $8,88 \%$ & $91,12 \%$ \\
Média & $10,25 \%$ & $89,75 \%$ \\
\hline
\end{tabular}

\subsection{Tratamento de Dados}

Os dados hidrológicos e hidroquímicos obtidos foram dispostos na forma de planilha do programa Excel $7.0 \AA$, foram construídos gráficos de dispersão entre o nutriente e a salinidade a fim de observar o comportamento do nutriente no sistema estuarino-lagunar.

Foram utilizados também para gerar gráficos que permitiram visualizar a distribuição espacial e temporal dos parâmetros medidos na área estudada com auxílio do programa Surfer $10 \AA$ e do programa GraphPad Prism $5 \AA$. Também foram geradas tabelas de correlação de Pearson, análise de cluster e PCA no software GraphPad Prism $5 \AA$.

Prastka et al. (1998) tem usado um modelo de equilíbrio que prevê os efeitos do aumento da entrada de $\mathrm{P}$ em rios e estuários na função do sistema costeiro aquático. Este tipo de modelo, também é conhecido como equilíbrio de partição, é utilizado em estudos biogeoquímicos ambientais (PAGLIOSA et al., 2005). O modelo usa o conceito de $K_{d}$ (coeficiente de partição) que é uma razão entre as concentrações do dissolvido e do particulado de qualquer constituinte em equilíbrio termodinâmico. Neste trabalho foi utilizado o $\triangle \mathrm{PID}$ (PRASTKA et al., 1998), que mensura a porcentagem de PID que está sendo adsorvido e virando PIP (valores positivos), e/ou a porcentagem de PIP que dessorve e vira PID (valores negativos).

O modelo é bem simples e prevê que o aumento na concentração de fósforo inorgânico dissolvido nos rios pode aumentar a remoção de fósforo de partículas em zonas de baixa salinidade nos estuários. Isso pode sugerir que a remoção de $\mathrm{P}$ é uma característica de sistemas estuarinos poluídos, enquanto 
que a liberação de fósforo para o mar adjacente ocorre em ambientes não poluídos (PRASTKA et al., 1998).

Neste estudo foi utilizada a média da concentração de PID, PIP, MPS e salinidade, entre as estações $R 1, R 2, R 3,4 A$ e 4 como referência para a concentração fluvial. O P adsorvido ou dessorvido foi calculado através da fórmula:

$$
\Delta P I D=\frac{(\text { PIDr. Kd. MPSe })-(\alpha . \text { IDr }(\text { MPSe }- \text { MPSr }))-(\text { MPSr.PTPr })}{1+(\text { Kd.MPSe }(1-\alpha))+(\alpha . K d . M P S r)}
$$

Onde:

$\mathrm{PIDr}=\mathrm{a}$ concentração média de $\mathrm{P}$ na coluna de água entre as estações de coleta do rio;

PIDe = a concentração de fósforo inorgânico dissolvido na estação de coleta do estuário;

$\mathrm{Kd}=\mathrm{PTPe} / \mathrm{PIDe}$;

$\mathrm{PTPe}=0$ fósforo total particulado na estação de coleta no estuário;

$\operatorname{PTPr}=$ a média do fósforo total particulado no rio;

MPSe = o material particulado em suspensão na estação de coleta do estuário;

MPSr = o material particulado em suspensão médio do rio;

$\alpha=($ PTPe-PTPr)/PTPe.

Portanto, a porcentagem de remoção de fósforo inorgânico dissolvido (\%PID) é calculada pela equação:

$$
\% P I D \text { removido }=\frac{\Delta P I D}{P T P r} \cdot 100
$$




\section{Resultados e Discussão}

\subsection{Climatologia e Hidrografia}

Os índices pluviométricos mensais nos anos de coleta estão representados na figura 10. Na cidade de Pariquera-Açú (localizada no continente próxima à Cananeia) em 2014 (Fig. 10 a) mostram as maiores precipitações nos meses de verão (novembro a março) com queda brusca em janeiro (comportamento atípico), mês que apresentou um dos menores índices do ano. Já no ano de 2015 (Fig. 10 b) o período com maior presença das chuvas foi de setembro a março, com queda em dezembro, enquanto que de maio a agosto pode-se observar o período de seca.

A região de Cananéia (Fig. 10 c;d), durante o verão recebe umidade proveniente dos ventos alísios, período em que houve um índice pluviométrico maior entre os meses de setembro a abril, com um evento de seca no mês de outubro em 2014 e em agosto de 2015. No ano de 2014 pode-se observar um período de seca entre maio e agosto bem marcado e característico do período, que recebe maior influência da massa de ar Polar (GUEDES, 2009). 

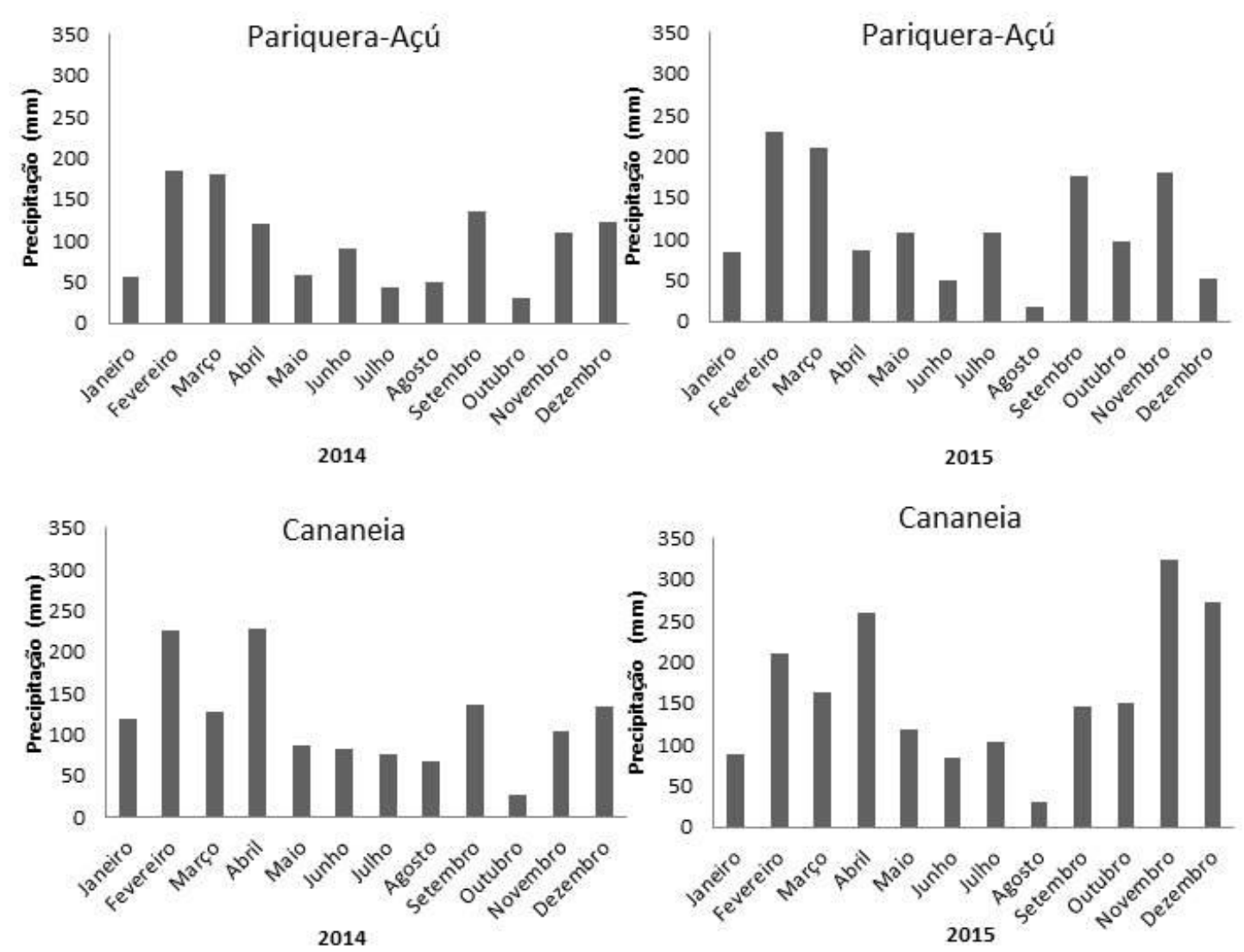

Figura 10. Precipitação mensal estação automática de Pariquera-Açú e Cananeia, com base nos dados divulgados em CIIAGRO, www.ciiagro.sp.gov.br, acesso em 26/02/2016.

Na tabela 4 é possível observar que o ano de 2014 foi atípico, contou com menores índices pluviométricos que causou umas das maiores secas na região sudeste do país, nas duas cidades, isto pode indicar que em 2015 houve uma maior intensidade da umidade vinda do oceano através da Zona de Convergência do Atlântico Sul (ZCAS) que intensifica a massa de ar Tropical Atlântica (GUEDES, 2009).

Tabela 4. Precipitação total anual nos anos de 2014 e 2015 nas cidades de PariqueraAçú e Cananeia, disponível em CIIAGRO, www.ciiagro.sp.gov.br, acesso em 26/02/2016.

\begin{tabular}{ccc}
\hline Cidade & Ano & Precipitação Anual (mm) \\
\hline Pariquera-Açú & 2014 & 1182,9 \\
Cananeia & 2014 & 1408,9 \\
Pariquera-Açú & 2015 & 1399,5 \\
Cananeia & 2015 & 1951,0 \\
\hline
\end{tabular}


A pluviosidade é um fator chave no sistema estuarino devido a sua relação com a vazão dos rios, que atua como transportador de água e partículas, uma maior precipitação pode levar a um possível aumento na capacidade de transporte do rio. Na coleta de agosto de 2014 (Fig. 10) a precipitação em Cananeia foi de 66,6 mm e em Pariquera-Açú 50,0 mm de acordo com CIIAGRO (Centro Integrado de Informações Agrometorológicas). Em 2011 para o mesmo período amostral foi registrada precipitação de $70 \mathrm{~mm}$ de acordo com dados do CPTEC (COELHO, 2011), nos anos de 2012 e 2013, $10 \mathrm{~mm}$ e $25 \mathrm{~mm}$ respectivamente (AGOSTINHO, 2015), de acordo com dados obtidos de CIIAGRO, portanto neste período nos últimos cinco anos houve uma tendência de diminuição da intensidade dos eventos de chuva.

Em maio de 2015, a precipitação em Cananeia foi de $118,1 \mathrm{~mm}$ e em Pariquera-Açú 107,0 mm (CIIAGRO, 2016). Em 2011 e 2012 em Cananeia, foi registrado 100,0 mm de pluviosidade (COELHO, 2011; AGOSTINHO, 2015), já em 2013 foi registrado $50,0 \mathrm{~mm}$. Neste período houve um pequeno aumento na pluviosidade no ano de 2015 , cerca de $20,0 \mathrm{~mm}$ com relação à coleta em agosto de 2014.

Outro ator extremamente importante para dinâmica do sistema estuarino é a maré, que rege a entrada de água salgada e a saída de água salobra. Durante a coleta de agosto de 2014 a curva de maré (Fig. 11) mostrou picos e vales bem definidos configurando maré de sizígia, as estações do rio (de R1 a R5), a estação 5 e a 6 foram realizadas durante o período de enchente, já as estações de 1 a 3 durante o período de vazante, próximas ao momento de estofa de maré baixa. Na plataforma continental a estação $\mathrm{MC1}$ foi realizada em maré enchente logo após a estofa de maré vazante, já a MC3 e MC5 foram amostradas no período de maré vazante. Próximo à estofa de maré enchente, foram coletadas as amostras da estação MI5, seguida da MI3 e MI1 na maré vazante. 


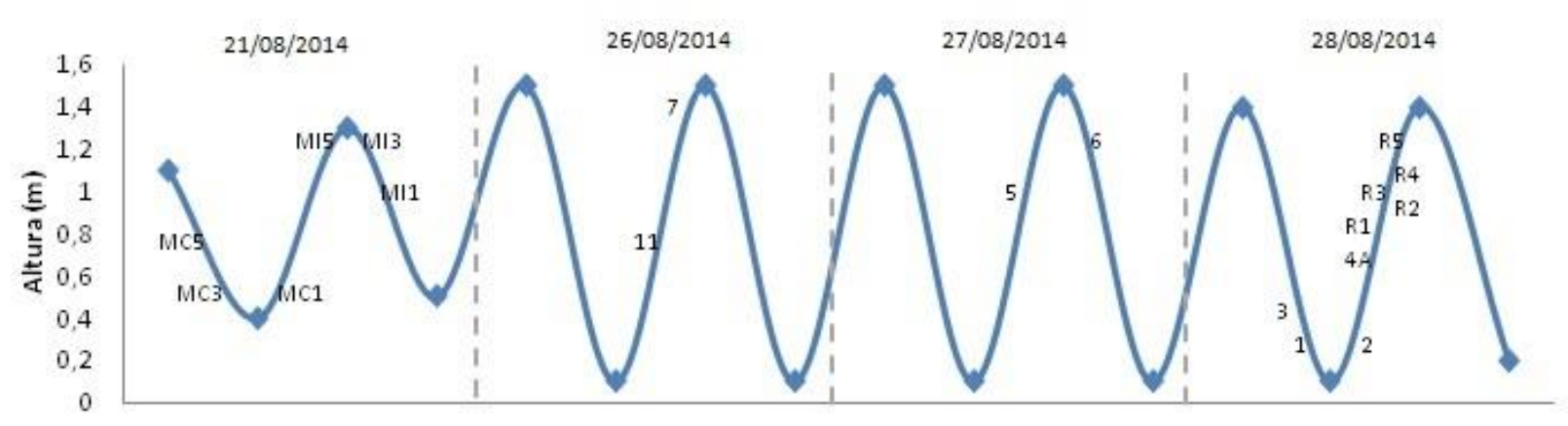

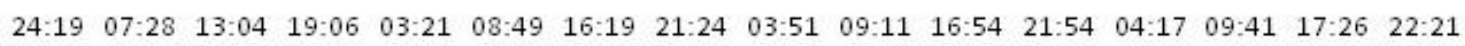
Dia-Horário (hr)

Figura 11. Curva de maré 21/08/2014, 26/08/2014 a 28/08/2014, com base nos dados divulgados em IOUSP, http://www.mares.io.usp.br/tabua/2014, acesso em 26/02/2016.

Durante o trabalho de campo de maio de 2015 de acordo com a curva de maré (Fig.12), ocorreram picos e vales bem definidos configurando maré de sizígia, exceto no dia 22 em que houve um prolongamento da estofa de maré. As estações do norte do sistema (rio e Iguape) foram realizadas durante a maré enchente, já a 5 e 6, localizadas na parte central do sistema, foram amostradas durante a maré vazante, no sul do sistema a 7 próxima a estofa de maré vazante e a 11 no momento de estofa de maré vazante. As amostras das estações Vale, Cajati e Registro foram coletadas durante o período de maré vazante, somente a título de curiosidade, pois não estão sob influência do regime de maré.

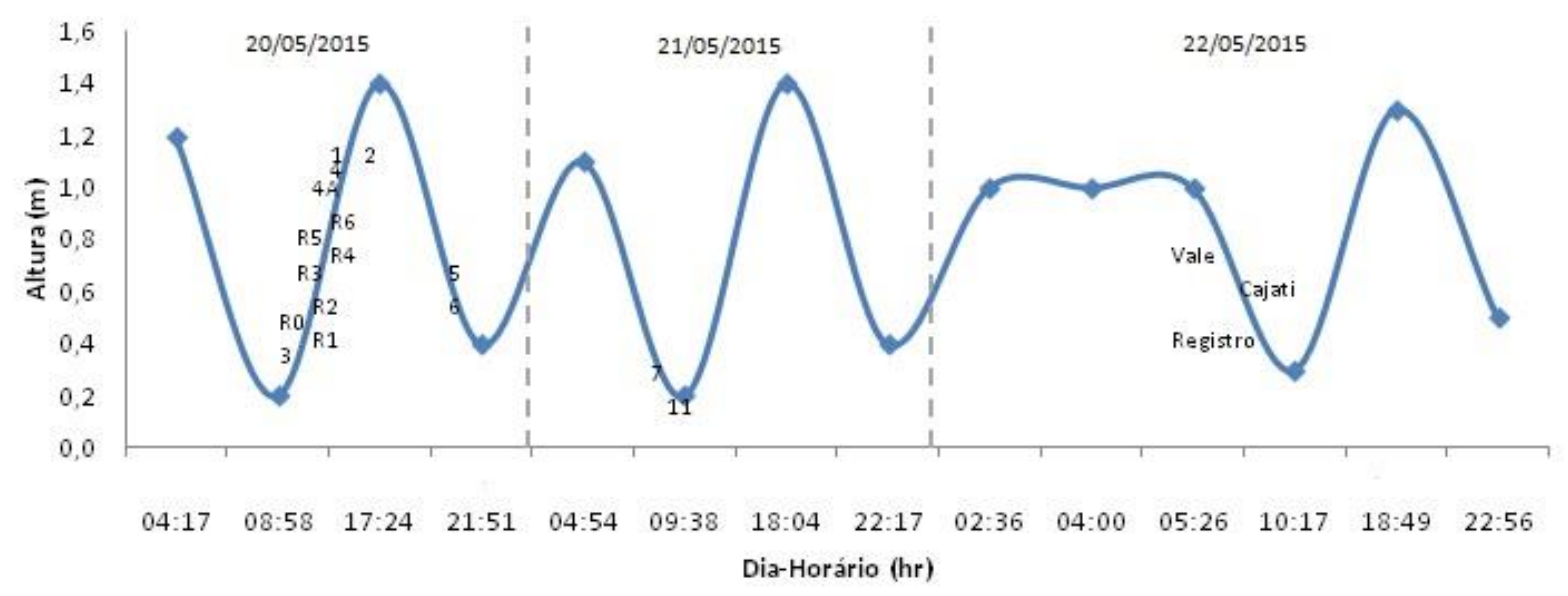

Figura 12. Curva de maré do dia 20 a 22/05/2015, com base nos dados divulgados em IOUSP, http://www.mares.io.usp.br/tabua/2015, acesso em 26/02/2016. 
É possível observar que as estações de rio sempre foram amostradas em maré enchente, porém, como será observado adiante, os valores de salinidade não revelam a entrada da água do mar no sistema e muito menos no rio. As demais estações foram amostradas em diferentes momentos de maré, será observado adiante que este efeito é reduzido no setor norte do sistema e mais sensível no setor sul do sistema, ou seja, nas estações 7 e 11 que estão em diferentes momentos de maré nos dois períodos, foi possível observar diferentes níveis de influência, como será abordado na discussão dos parâmetros hidrológicos e hidroquímicos.

\subsection{Hidrologia e Hidroquímica do sistema estuarino-lagunar de Cananeia-Iguape (SP)}

Em uma abordagem que trate do estuário como um todo, pode-se observar uma distinção bem marcada dos seguimentos norte e sul do complexo estuarino-lagunar de Cananeia-lguape, este comportamento já foi indicado por diversos autores (ESCHRIQUE, 2011; COELHO, 2011; BASTOS, 2014; AGOSTINHO, 2015).

A temperatura da água observada em agosto de 2014 (Fig. 13a) variou de $20,70^{\circ} \mathrm{C}$, na estação 1 (próxima à Barra de Icapara), a $22,80^{\circ} \mathrm{C}$, nas estações R1 a R5 e 6. Houve, portanto, um maior aquecimento das águas fluviais em relação a água salobra e marinha, esta tendência também foi observada por Bastos (2014) e também no centro do sistema (estação 6). Eschrique (2011), Coelho (2011) e Agostinho (2015), no mesmo período sazonal, encontraram uma tendência inversa, ou seja, um resfriamento das águas fluviais e um aquecimento das águas salobras e marinhas no sistema.

No trabalho atual, considerando-se apenas as águas do rio Ribeira de Iguape, observou-se uma leve estratificação nas estações R2, R3, R4 e R5, com água levemente mais fria no fundo (Fig. 14a). Em maio de 2015 (Fig. 14b) houve uma maior variação de $20,50^{\circ} \mathrm{C}$ na estação Cajati a $23,9^{\circ} \mathrm{C}$ na estação Vale, nesta última a temperatura foi mais elevada, provavelmente devido à coleta ter sido realizada em um braço do rio Guaraú, que passa pela empresa de mineração, com poucos centímetros de lâmina d'água. 
Em maio, nas estações do sistema (Fig. 13d), se observa a formação de dois agrupamentos: um no setor norte, com águas menos aquecidas, com temperaturas entre $21,51^{\circ} \mathrm{C}$ e $22,50^{\circ} \mathrm{C}$, e outro no setor sul, com águas mais aquecidas, com temperaturas entre $22,51^{\circ} \mathrm{C}$ e $23,50^{\circ} \mathrm{C}$.

De uma forma geral, as estações do Rio Ribeira de Iguape, mostraram valores de temperatura menores no inverno e mais homogêneos, e como ocorre no outono, há uma característica de uma variação mais ampla nas temperaturas, mais facilmente observada no sistema como um todo (BRAGA, 1995).

Em agosto de 2014, considerando todo o sistema estudado, os valores de salinidade encontrados variaram de 0,03 a 34,16. Nas estações de rio (Fig. 14c) foram encontrados valores de salinidade entre 0,03 e 1,10 (4A). Nas estações estuarinas (Fig. 13b) do setor norte (1, 2 e 3), esse parâmetro sofreu alterações que devem estar associadas aos momentos de maré enchente, assim encontramos um aumento entre 1,0 e 5,0 nas estações 2 e 3, e um aumento entre 15,0 e 25,0 na estação 1, verificando-se a influência da água marinha, porém os valores não atingem as características de água salgada em nenhum ponto dentro do sistema. Nas estações da plataforma (Ml1 a MI5 e MC1 a MC5) a salinidade apresentou os teores mais altos, com valores característicos de água salgada (>30). No setor sul do complexo estuarinolagunar de Cananeia-Iguape a salinidade apresentou valores característicos de águas estuarinas com salinidade maior que 0,05 e menor que 30,00.

No setor norte do estuário, observou-se que em maio de 2015 (Fig. $13 e ; 14 d)$ que a salinidade sofreu uma pequena variação entre 0,00 e 0,04, exceto na estação 1 que apresentou aumento para 4,70, devido à proximidade da Barra de Icapara, estando assim, sob maior influência da água marinha. Em direção ao setor sul do sistema, no interior do complexo estuarino, a estação 6 apresentou salinidade 7,96, enquanto na estação 7 o valor passou para 17,00 e na estação 11 atingiu 22,00. Todos estes valores são característicos de água salobra.

Com o canal artificial fechado Miyao et al. (1986) em estação fixa localizada no setor norte do sistema estuarino, obteve em janeiro de 1980 salinidade de aproximadamente 18,0, Braga (1995) encontrou valor mínimo de salinidade de 26,97 em Cananeia, enquanto DAEE (1989) relatou valores de 
salinidade entre 16 e 34, porém com o Valo aberto o órgão encontrou valores entre 0 e 32. Neste trabalho observou-se um aumento da salinidade de Iguape em direção a Cananeia, tanto no período de inverno e outono devido à influência da abertura do Valo Grande e seu aporte de água doce ao sistema estuarino, como também apontado em Maluf (2009), Coelho (2011), Eschrique (2011), Bastos (2014) e Agostinho (2015).

Em agosto de 2014 (Figs. 13c; 14e) pode-se observar que os valores de $\mathrm{pH}$ variaram de 7,00 nas estações do rio a 8,50, observado nas estações com maior influência marinha (1, 7 e 11). Em maio de 2015 (Figs. 13f; 14f) houve uma variação maior do $\mathrm{pH}$, indo de 5,33 na estação Vale, localizada em um córrego que transporta o rejeito da mineração de fluorapatita para as lagoas de decantação, a 7,95 nas estações 7 e 11.

Observando os níveis de $\mathrm{pH}$ e de salinidade pode-se verificar que a influência do rio se estendeu desde o Valo Grande até a estação 5.

Os valores de pH em torno de 8, são encontrados em águas marinhas, sendo que em estuários os valores diminuem um pouco, mostrando os movimentos de mistura da entrada da água salina e saída de água doce. Neste trabalho os valores mais baixos de $\mathrm{pH}$ foram observados sobretudo no setor norte do sistema estuarino, na região de influência do deságue do Rio Ribeira de Iguape via Valo Grande, principalmente no período referente ao outono de 2015 , onde a vazão e a pluviosidade devem ter influenciado no espalhamento dessas águas pelo sistema estuarino.

Após a abertura do canal do Valo Grande, a entrada de água doce com altos teores de MPS, nutrientes e contaminantes, provenientes do rio Ribeira de Iguape, foi facilitada de modo a alterar a salinidade regional e as condições químicas do sistema estuarino-lagunar de Cananeia-Iguape. 

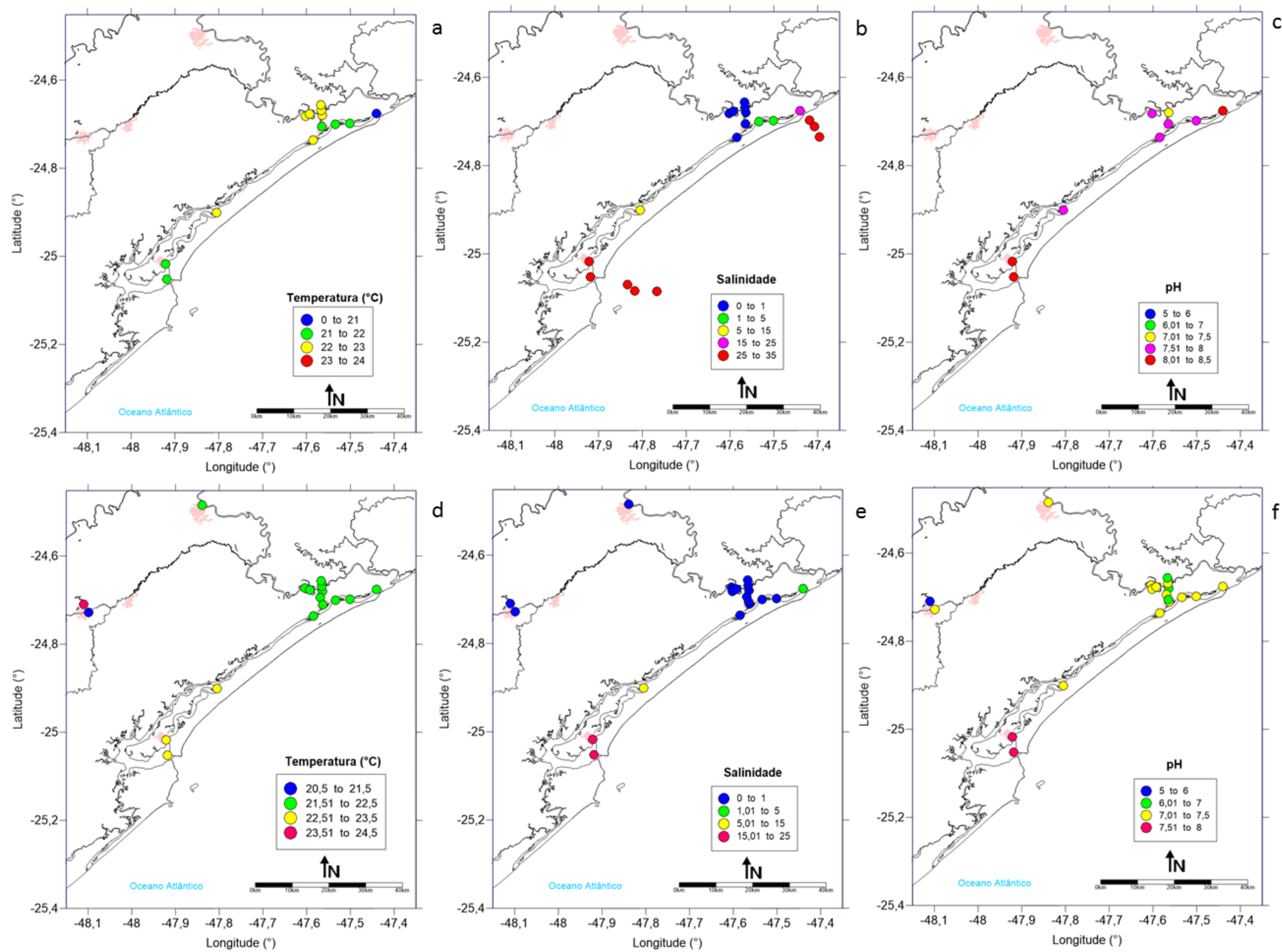

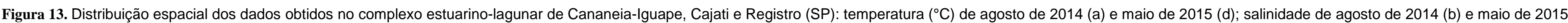
(e); pH de agosto de 2014 (c) e maio de 2015 (f). 

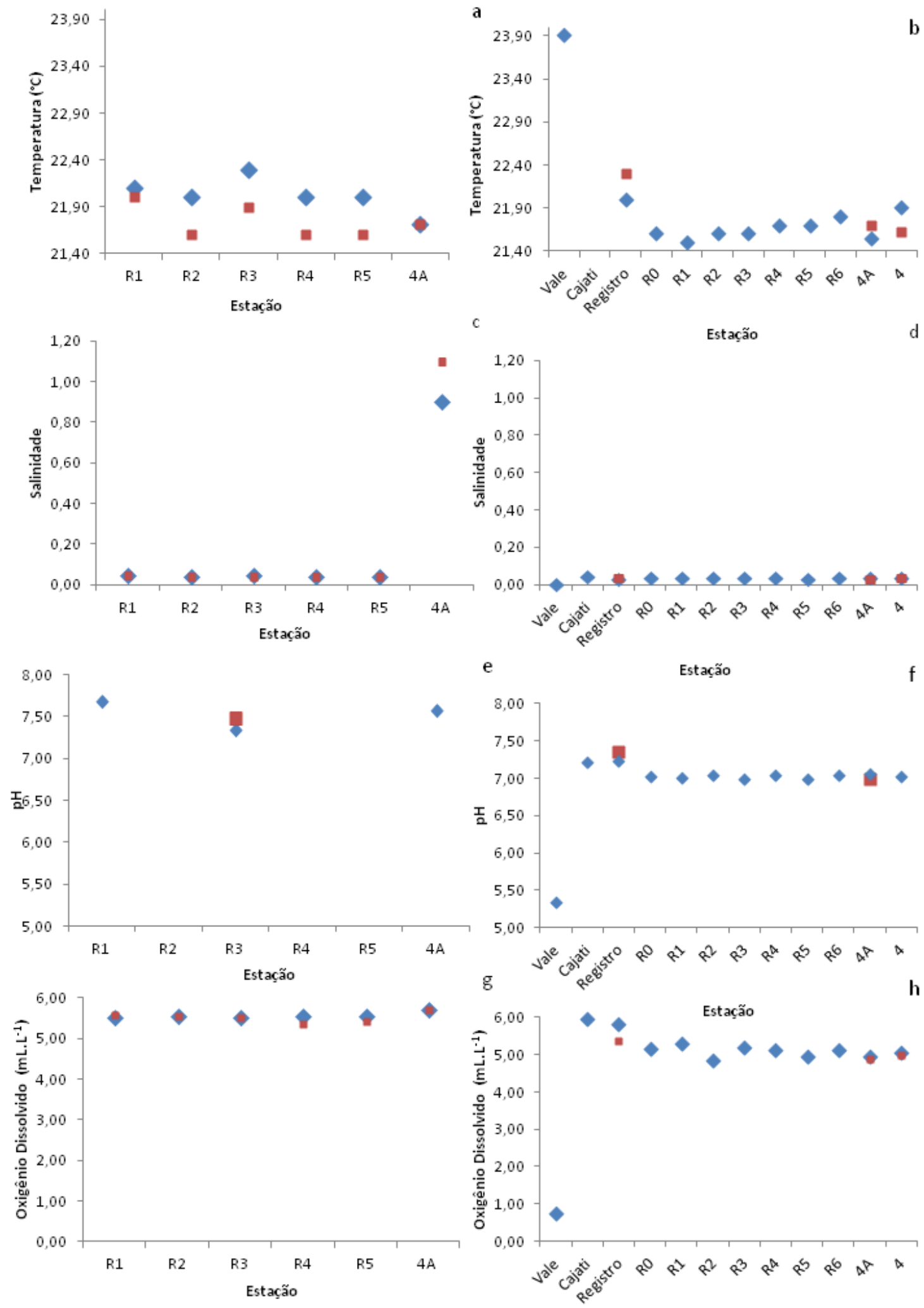

Estação

Figura 14. Distribuição espacial dos dados coletados nos rios Guaraú, Ribeira de Iguape e canal do Valo Grande (SP): temperatura $\left({ }^{\circ} \mathrm{C}\right)$ de agosto de 2014 (a) e maio de 2015 (b); salinidade de agosto de 2014 (c) e maio de 2015 (d); pH de agosto de 2014 (e) e maio de 2015 (f); oxigênio dissolvido ( $\mathrm{mL} \mathrm{L}^{-1}$ ) de agosto de $2014(\mathrm{~g})$ e maio de 2015 (h). O losango azul representa os dados de superfície e o quadrado vermelho representa os dados de fundo 
Os valores de oxigênio dissolvido em agosto de 2014 (Fig. 18a) variaram de 4,49 $\mathrm{mL} \mathrm{L}^{-1}$ a $6,77 \mathrm{~mL} \mathrm{~L}^{-1}$, indicando que o sistema como um todo, pode ser considerado portanto um ambiente bem aerado e com água correntes em todo o sistema. Enquanto em maio de 2015 (Figs. 14h;18d) na estação Vale houve um ponto de anoxia $\left(0,75 \mathrm{~mL} \mathrm{~L}^{-1}\right)$, pois este córrego é o que transporta o rejeito da mineração para as lagoas de decantação e a água encontrava-se em péssimas condições neste trecho (Fig. 15a,b). Nas demais amostras deste período, a variação do OD foi de $4,01 \mathrm{~mL} \mathrm{~L}^{-1}$ a $5,97 \mathrm{~mL} \mathrm{~L}^{-1}$, os valores indicam que todos os setores do sistema estavam bem oxigenados.

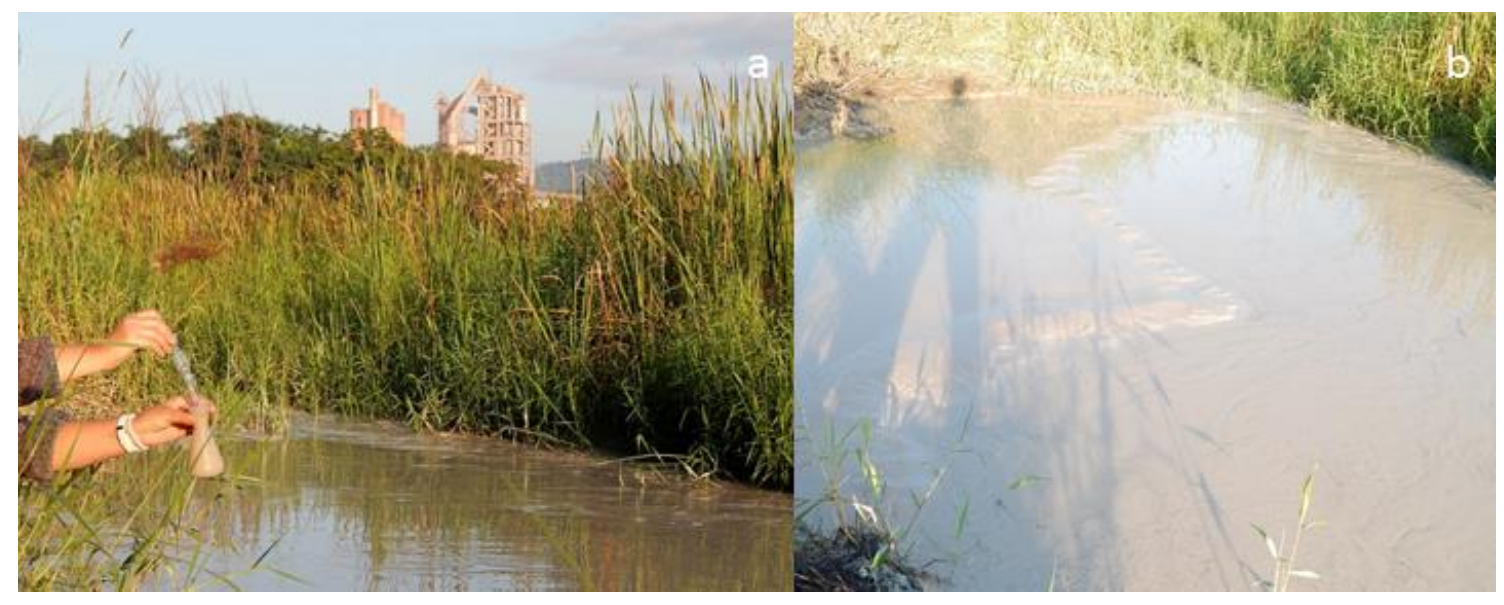

Figura 15. a) Imagem da amostragem de OD na estação Vale; b) Imagem aspecto do córrego que transporta o resíduo para as lagoas de decantação (Fonte: BRAGA, E.S., maio de 2015).

Como pode ser observado, no geral, durante o período de inverno os teores de OD foram mais elevados. Este comportamento é comum, pois no inverno a temperatura da água foi menor e mais homogênea, facilitando a solubilização dos gases, dentre eles o OD. Outros autores também encontraram este padrão de distribuição no sistema estuarino-lagunar de Cananeia-Iguape (SP) Braga (1995), Berbel (2008), Maluf (2009), Coelho (2011), Eschrique (2011), Bastos (2014) e Agostinho (2015).

Os teores de turbidez no período de inverno (Figs. 16a;18b) variaram entre 8,78 NTU em R5 e 24,30 NTU em 4A, o aumento do parâmetro na estação $4 A$ pode indicar uma pequena influência da maré enchente que pode aprisionar o material fino, que sairia pela barra de Icapara. No outono (Fig. 16b; 18d) houve variação entre 7,74 NTU em Cajati e 26,40 NTU na estação 4, 
porém na estação da Vale o valor encontrado foi >1000 NTU, esta amostra apresenta uma grande concentração de finos particulados em suspensão provenientes do processo de mineração, sua coloração é leitosa como pode ser observado na figura 15 a,b. Na estação 4 há uma inversão, a superfície está mais turva que o fundo, isto pode indicar transporte de partículas finas em superfície (Fig. 16b).

Dando enfoque às estações localizadas no rio (Fig. 16 a, b), houve no inverno de 2014 valores de turbidez na superfície e fundo com menor amplitude de variação do que os observados na outono de 2015, isso pode indicar maior mistura das águas em agosto de 2014, exceto na estação 4A como já indicado, pela salinidade $(1,10)$, há influência da água marinha.

Nas duas campanhas realizadas neste trabalho, foram encontrados os valores mais altos de turbidez nas estações 2 e 3, como também indicado por Bastos (2014) nestas estações localiza-se a zona de máxima turbidez (ZMT) e baixo OD. A ZMT é gerada por interações complexas entre a morfologia do canal, assimetria da maré, circulação gravitacional e a composição e textura do sedimento, como será abordado adiante estas estações são compostas por areia argilosa. Segundo Pisetta (2010), no canal do Valo Grande não há possibilidade de formação da ZMT, devido à contínua vazão fluvial e a pequena influência marinha.

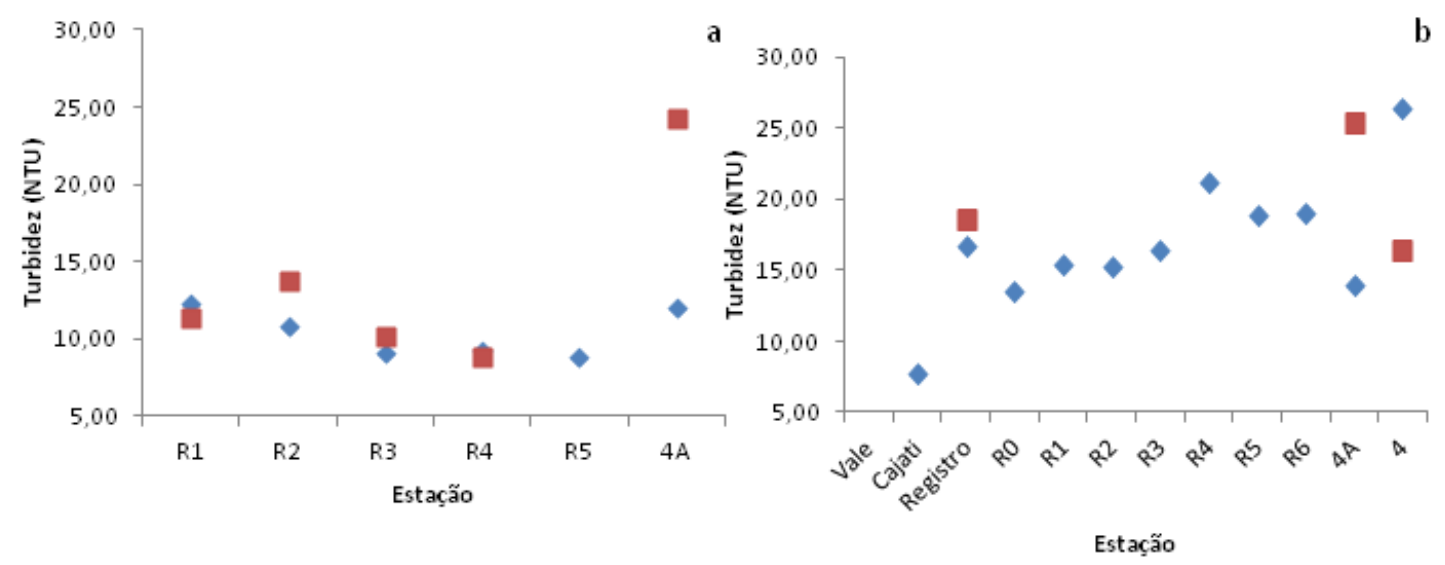

Figura 16. Distribuição espacial da turbidez (ntu) das estações dos rios Guaraú, Ribeira de Iguape e canal do Valo Grande (SP): agosto de 2014 (a) e maio de 2015 (b).

O silicato dissolvido no inverno de 2014 (Fig. 18c) apresentou distribuição de valores entre $3,09 \mu \mathrm{mol} \mathrm{L}^{-1}$ e $259,13 \mu \mathrm{mol} \mathrm{L} \mathrm{L}^{-1}$. Nas estações do setor norte do estuário, pode-se observar os maiores valores, devido à entrada 
de água doce através do rio Ribeira de Iguape no sistema via Canal do Valo Grande acompanhada das contribuições terrestres. Foram encontrados valores de silicato entre 205,53 $\mu \mathrm{mol} \mathrm{L}{ }^{-1}$ na superfície da estação 4A e 259,13 $\mu \mathrm{mol} \mathrm{L}^{-1}$ na água de fundo da mesma estação. Nesse período foi possível observar uma influência fluvial nas estações junto à Barra de Icapara com valores de silicato entre $12,00 \mu \mathrm{mol} \mathrm{L}^{-1}$ e 20,00 $\mu \mathrm{mol} \mathrm{L}^{-1}$, valores altos em comparação à Barra de Cananeia no setor Sul que apresentou valores entre 3,09 $\mu \mathrm{mol} \mathrm{L}^{-1}$ e 9,03 $\mu \mathrm{mol}$ $L^{-1}$. No verão de 2013, Bastos (2014) encontrou na estação Ml1 silicato em concentração $>100,00 \mu \mathrm{mol} \mathrm{L} \mathrm{L}^{-1}$ enquanto que no presente trabalho foi observado um valor de $15,19 \mu \mathrm{mol} \mathrm{L}^{-1}$, esta diferença pode estar relacionada ao período sazonal. No inverno de 2007 Eschrique (2011) encontrou no estuário do rio Jaguaribe, valores de silicato entre $14,15 \mu \mathrm{mol} \mathrm{L^{-1 }}$ na estação próxima à foz do rio e $288,44 \mu \mathrm{mol} \mathrm{L}^{-1}$ na estação mais interna do rio.

No outono de 2015 (Fig. 18f) a variação de silicato dissolvido esteve entre $11,27 \mu \mathrm{mol} \mathrm{L} \mathrm{L}^{-1}$ na estação Vale e $263,24 \mu \mathrm{mol} \mathrm{L}^{-1}$ na estação $4 \mathrm{~A}$ (localizada no Valo Grande). Nesta campanha foram encontradas concentrações mais altas em relação ao inverno, também foi observada uma maior concentração de silicato no sistema estuarino, na área de influência do rio Ribeira de Iguape no sistema estuarino.

A entrada do silicato no sistema hídrico está relacionada aos processos continentais de intemperismo e lixiviação, que são facilitados pela ocupação do solo das margens do rio Ribeira de Iguape com áreas de pasto degradado, bananicultura e sem área de mata ciliar preservada. Esta configuração favorece a entrada de materiais terrígenos no rio, que age como meio de transporte para o estuário.

Nas duas campanhas realizadas houve uma maior concentração do silicato dissolvido no setor norte do sistema, junto à pluma de influência do rio Ribeira de Iguape que atinge da estação 1 até a estação 5 deste trabalho.

Como pode ser observado no diagrama de dispersão (Fig. 17a) em agosto de 2014, o silicato dissolvido foi removido da coluna d'água ao longo do estuário (pontos abaixo da reta de diluição teórica). Essa remoção pode ocorrer devido à adsorção ao MPS e a diluição estuarina devido à variação dos valores de salinidade. Portando nesta campanha o silicato apresentou comportamento não conservativo ao longo do gradiente de salinidade. 
Em maio de 2015 (Fig. 17b), os processos de remoção de silicato estiveram um pouco menos evidentes, ocorrendo principalmente em pontos de salinidade próxima a 10. O comportamento do silicato de acordo com o gradiente de salinidade observado neste trabalho (remoção) está de acordo com o encontrado por Bastos (2014), que é o contrário do encontrado por outros autores (BRAGA et al., 2009; COELHO, 2011 e ESCHRIQUE, 2011) que indicam o sistema estuarino-lagunar de Cananeia-Iguape como um ambiente conservativo.
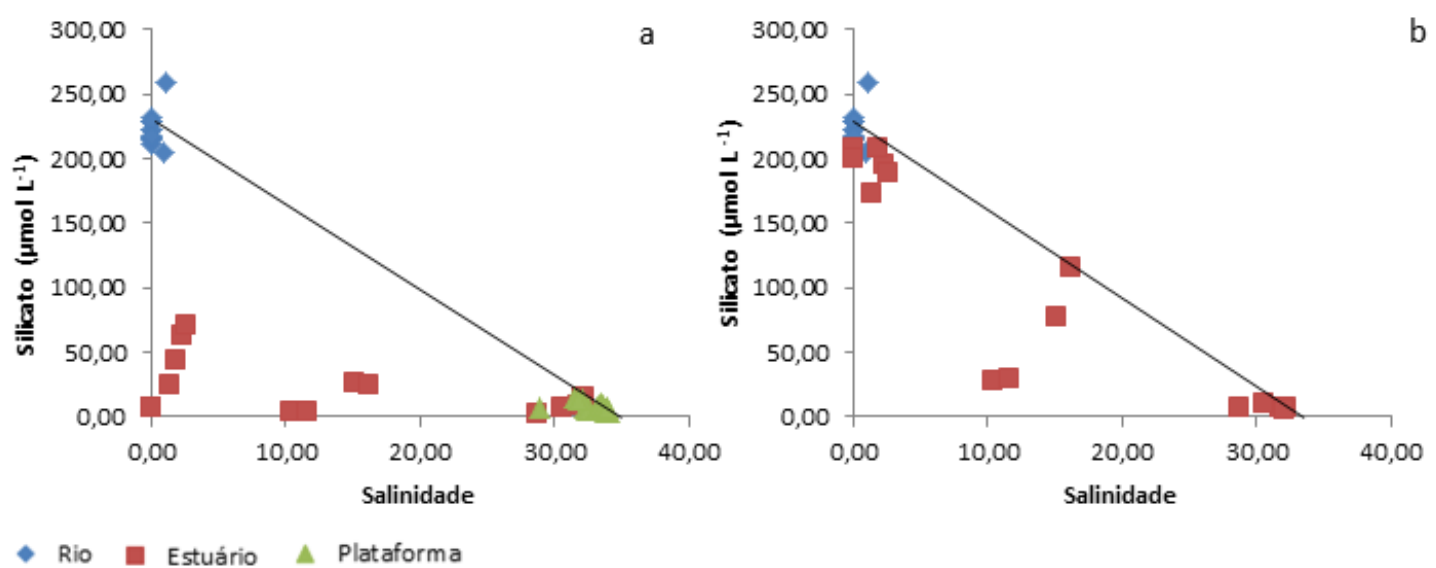

Figura 17. Diagrama de dispersão de silicato dissolvido $\left(\mu \mathrm{mol} \mathrm{L}^{-1}\right)$ com relação à salinidade: agosto de 2014 (a) e maio de 2015 (b) no sistema estuarino-lagunar de Cananeia-Iguape, Cajati e Registro (SP). 

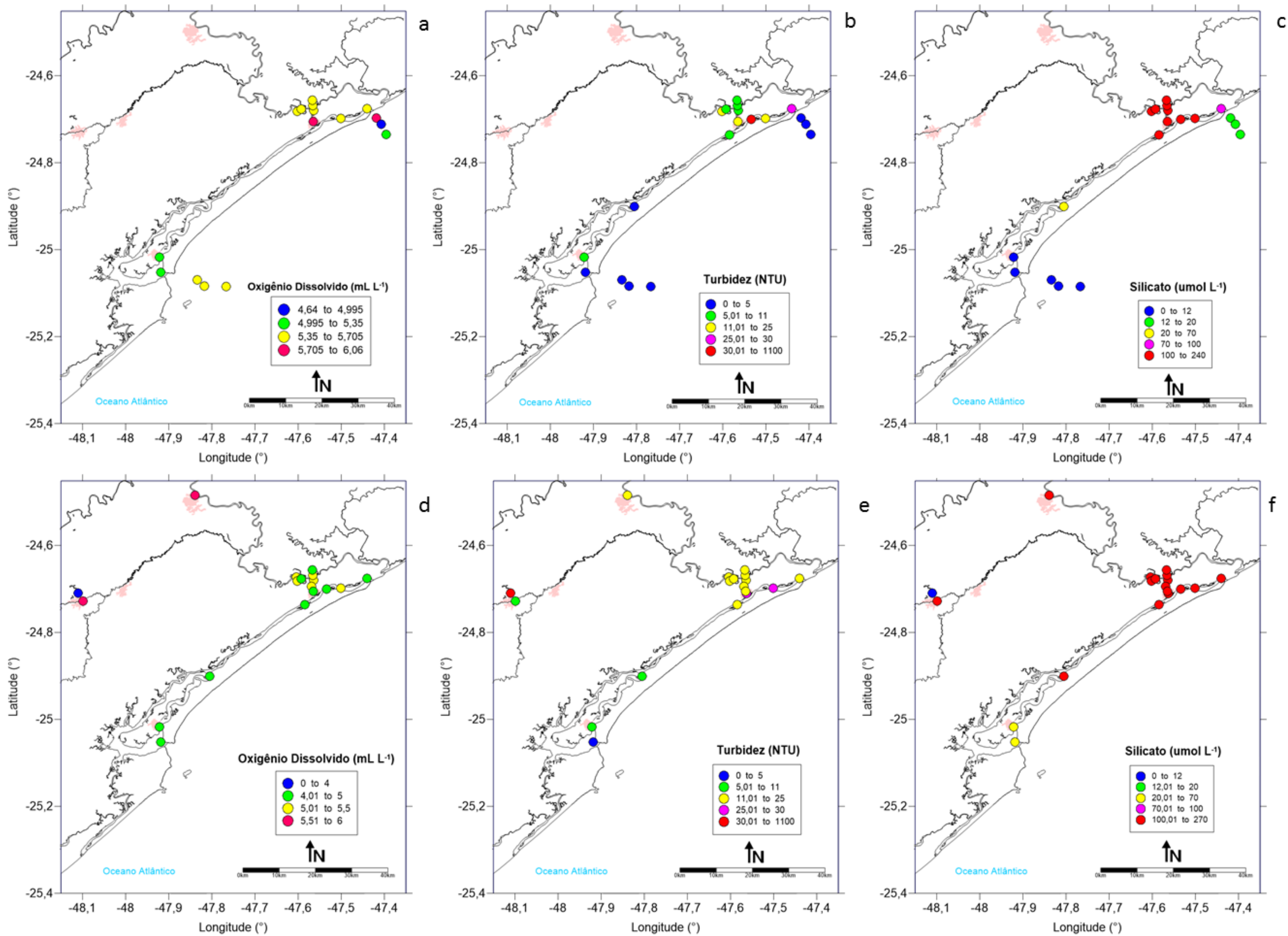

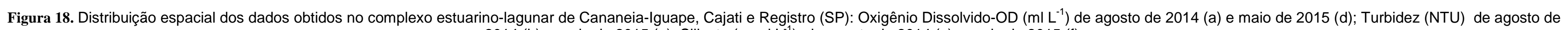
2014 (b) e maio de 2015 (e); Silicato ( $\mu \mathrm{mol} \mathrm{L}^{-1}$ ) de agosto de 2014 (c) e maio de 2015 (f). 
Outro nutriente que possui sua entrada no sistema aquático através do intemperismo e da lixiviação do solo e das rochas continentais é o fosfato. $O$ fósforo inorgânico dissolvido (fosfato dissolvido) também pode ser introduzido no corpo hídrico através da utilização de fertilizantes na agricultura e do despejo de esgoto doméstico. Em agosto de 2014 (Fig. 19a) os valores encontrados de PID foram de $0,24 \mu \mathrm{mol} \mathrm{L}{ }^{-1}$ na estação MC5 a $13,89 \mu \mathrm{mol} \mathrm{L}^{-1}$ na estação R1. As concentrações mais baixas foram encontradas nas estações próximas às Barras de Cananeia (estações de MC1 a MC5) e Icapara (estações de Ml1 a MI5).

Em estudo realizado no inverno de 2009 no sistema estuarino-lagunar de Cananeia-Iguape (SP), Coelho (2011) encontrou valores de PID entre 0,35 $\mu \mathrm{mol} \mathrm{L}^{-1}$ e $1,0 \mu \mathrm{mol} \mathrm{L}{ }^{-1}$ na região de Cananeia e entre $1,59 \mu \mathrm{mol} \mathrm{L}^{-1}$ e 3,47 $\mu \mathrm{mol}$ $\mathrm{L}^{-1}$ na região de Iguape. Bastos (2014) e Agostinho (2015) no inverno de 2012 encontraram valores mais próximos deste trabalho, entre $0,24 \mu \mathrm{mol} \mathrm{L} \mathrm{L}^{-1}$ e 12,45 $\mu \mathrm{mol} \mathrm{L}^{-1}$. Eschrique (2011) no estuário do rio Jaguaribe (CE) no inverno de 2007 encontrou valores de PID ainda mais baixos de $0,08 \mu \mathrm{mol} \mathrm{L}^{-1}$ a 2,24 $\mu \mathrm{mol}$ $\mathrm{L}^{-1}$. No caso de Cananéia, com o Valo Grande fechado, Miyao et al. (1986) encontrou, em estação localizada no setor norte do sistema estuarino-lagunar de Cananeia-Iguape, 0,3 $\mu \mathrm{mol} \mathrm{L}^{-1}$ de fosfato e Braga (1995) encontrou em Cananéia valores de PID entre 0,04 e 0,46 $\mu \mathrm{mol} \mathrm{L}^{-1}$, em agosto de 1992.

No inverno de 2000, Aguiar e Braga (2007) observaram no sistema estuarino de Santos-São Vicente valores de PID que variam entre $0,83 \mu \mathrm{mol} \mathrm{L}^{-1}$ e $14,54 \mu \mathrm{mol} \mathrm{L}^{-1}$, esta área no estado de São Paulo corresponde a uma das regiões mais poluídas, pois está instalado o Polo Industrial-Petroquímico de Cubatão. Mesmo a fonte de fósforo sendo distinta nos dois estuários, os valores de fósforo são próximos.

Em maio de 2015 (Fig. 19d) os valores foram de 0,28 $\mu \mathrm{mol} \mathrm{L}^{-1}$ na estação 11 a $12.665,44 \mu \mathrm{mol}^{-1}$ na estação Vale, este valor está extremamente alto, pois a coleta foi realizada no córrego que transporta 0 rejeito da mineração de fluoroapatita para as lagoas de decantação, que têm a função de reter os poluentes oriuntos da atividade mineradora. Em coleta realizada logo após a lagoa de decantação, ponto em que a água já retornou para o rio Guaraú (estação Cajati) o teor de fosfato encontrado foi de 13,60 $\mu \mathrm{mol} \mathrm{L} \mathrm{L}^{-1}$. 
No outono de 2007, Maluf (2009) encontrou no setor norte do sistema estuarino-lagunar de Cananeia-Iguape (SP) uma varição de PID entre 1,56 $\mu \mathrm{mol} \mathrm{L} \mathrm{L}^{-1}$ e 4,30 $\mu \mathrm{mol} \mathrm{L} \mathrm{L}^{-1}$. Neste trabalho, os valores deste setor do estuário estiveram entre $2,5 \mu \mathrm{mol} \mathrm{L} \mathrm{L}^{-1}$ e $5,0 \mu \mathrm{mol} \mathrm{L^{-1 }}$, portanto mais elevados que os observados pelo autor citado.

Barrera-Alba et al. (2009) indicam, que desde 2002 está havendo um aumento nas concentrações de PID em águas do setor norte do sistema estuarino-lagunar de Cananeia-Iguape (SP), levando o corpo hídrico a um processo de eutrofização artificial, que pode ser observado pela diminuição de oxigênio dissolvido.

Valores acima de $10 \mu \mathrm{mol} \mathrm{L}^{-1}$ foram observados apenas na água doce até o momento no sistema, tanto em Agosto 2014, quanto em Maio 2015, e o valores até $5 \mu \mathrm{mol} \mathrm{L^{-1 }}$, foram observados no norte do sistema nos dois períodos, mas efetiva diluição ainda está ocorrendo em direção sul.

Também foi determinado o fósforo orgânico dissolvido (POD) que compõe a fração orgânica do fósforo. Em agosto de 2014 (Fig. 20c) o POD encontrado variou de $\angle \mathrm{LD}$ (valor menor que o limite de detecção do método) em diversas estações [R2, R5, 4A, $1(0 \mathrm{~m}), 5,6,11$ e MI5] a 2,00 $\mu \mathrm{mol} \mathrm{L}^{-1}$ na estação $1(3 \mathrm{~m})$, este valor pode ter sofrido influência da entrada de água marinha devido ao momento de maré na coleta. Em maio de 2015 (Figs. 19e; 20d) a variação foi de $\angle L D$ nas estações: Registro, Cajati, R0, R2, R5, R6, 2, 3, 4 e 5 a $2,01 \mu \mathrm{mol} \mathrm{L}^{-1}$ na estação $4 \mathrm{~A}$, houve um aumento expressivo na estação Vale que apresentou valor de 5.639,03 $\mu \mathrm{mol} \mathrm{L}^{-1}$.

No inverno de 2009 Coelho (2011) apresentou volres de POD entre $<L D$ e $0,33 \mu \mathrm{mol} \mathrm{L} \mathrm{L}^{-1}$. No estuário do rio Jaguaribe (CE) no inverno de 2007 , foi encontrada uma variação entre $0,02 \mu \mathrm{mol} \mathrm{L}^{-1}$ e $1,60 \mu \mathrm{mol} \mathrm{L}^{-1}$ (ESCHRIQUE, 2011). Neste trabalho podem-se observar valores mais elevados de POD no sistema hídrico, mesmo com a implantação de obras de coleta de esgoto nas cidades de Registro, Cajati, Jacupiranga e Pariquera-Açú, realizadas no ano de 2013 (CETESB, 2015). Em trabalho realizado com canal do Valo Grande fechado Braga (1995), apresentou valores de POD para Cananéia, no inverno,

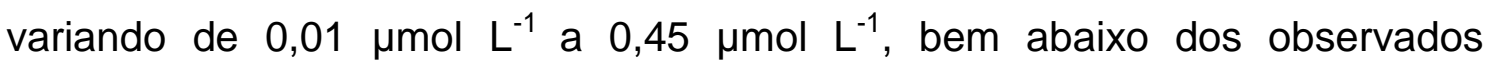
recentemente. Este é mais um fator que pode indicar que após a manutenção 
da abertura do canal o rio Ribeira de lguape está servindo de fonte expressiva do referido nutriente para o corpo estuarino.

Segundo Lin et al. (2013), em pesquisa realizada no estuário do rio Jiulong (China), localizado próximo à cidade de Taiwan, sofre grande influência antrópica e possui grandes cocentrações de nutrientes. A variação de PID encontrada pelos autores foi entre $0,52 \mu \mathrm{mol} \mathrm{L}^{-1}$ e 2,14 $\mu \mathrm{mol} \mathrm{L}{ }^{-1}$, os maiores valores foram localizados nos pontos de coleta mais próximos do rio e a concentração diminuiu em direção ao ponto de entrada de água marinha. $\mathrm{O}$ POD variou de $0,47 \mu \mathrm{mol} \mathrm{L}^{-1}$ a $0,62 \mu \mathrm{mol} \mathrm{L} \mathrm{L}^{-1}$. No sistema estuarino-lagunar de Cananeia-Iguape os valores de PID encontrados foram mais elevados, indicando uma inserção de $\mathrm{P}$ mais elevada do que a do estuário do rio Jiulong.

Em agosto de 2014 (Fig. 19c) os valores de fósforo total dissolvido (PTD) nas estações sob influência fluvial, ficaram entre $5,33 \mu \mathrm{mol} \mathrm{L}^{-1}$ na estação 4A e 15,57 $\mu \mathrm{mol} \mathrm{L}^{-1}$ na R1. Já em maio de 2015 (Fig. 19f) a variação foi de $1,19 \mu \mathrm{mol} \mathrm{L}{ }^{-1}$ na estação Registro a $13,60 \mu \mathrm{mol} \mathrm{L}^{-1}$ na Cajati, na estação Vale foi encontrado o maior valore de PTD $18304,47 \mu \mathrm{mol} \mathrm{L}^{-1}$, por este gráfico (Fig. 20 b,f) é possível indicar que a inserção de fósforo no rio Ribeira de Iguape pode ocorrer à jusante da cidade de Registro. Há, portanto, nas duas campanhas uma tendência de diminuição do PTD em direção ao Mar de Cananeia.

Pagliosa et al. (2005) em estudo realizado em rios que passam em áreas urbanizadas e não urbanizadas na Baía da llha de Santa Catarina, encontraram valores de PTD que atingiram o máximo de $12,5 \mu \mathrm{mol} \mathrm{L}^{-1}$, com predominância da forma orgânica. Neste trabalho nas duas campanhas realizadas os máximos valores encontrados estiveram mais altos que os citados por esse autor, e a maior fração está na forma de PID.

De acordo com o Relatório da Qualidade das Águas Superficiais no Estado de São Paulo, ano base 2014, realizado pela Companhia Ambiental do Estado de São Paulo (CETESB, 2015), a bacia do rio Ribeira de Iguape é considerada bandeira verde de acordo com O IQA (Índice de Qualidade Ambiental). No entanto, o monitoramento realizado aponta valores (em médias anuais) altos de fósforo nos rios da planície costeira da bacia, como o rio

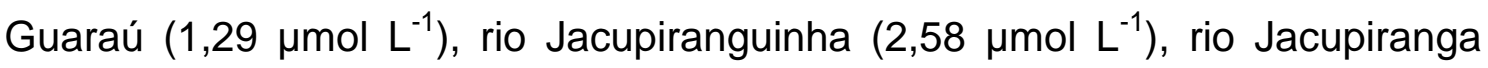


$\left(196,77 \mu \mathrm{mol} \mathrm{L}{ }^{-1}\right)$ e em dois pontos do rio Ribeira de lguape $\left(7,09 \mu \mathrm{mol} \mathrm{L} \mathrm{L}^{-1} \mathrm{e}\right.$ $6,12 \mu \mathrm{mol} \mathrm{L^{-1 }}$ ) à jusante da cidade de Registro (CETESB, 2015).

No trabalho atual em coleta realizada no rio Guaraú o valor de PTD encontrado, em maio de 2015, foi de $13,60 \mu \mathrm{mol} \mathrm{L}^{-1}$ (estação Cajati), valor mais alto em comparação ao apontado pelo relatório da CETESB. No entanto os valores de PTD dos pontos de monitoramento no rio Ribeira de Iguape à jusante de Registro, estão similares aos encontrados neste trabalho na campanha de maio de 2015 e estão entre $4,00 \mu \mathrm{mol} \mathrm{L}^{-1}$ e $5,00 \mu \mathrm{mol} \mathrm{L}^{-1}$, porém em agosto de 2014 os valores estiveram mais elevados, entre $5,00 \mu \mathrm{mol} \mathrm{L}^{-1} \mathrm{e}$ $16,00 \mu \mathrm{mol} \mathrm{L} \mathrm{L}^{-1}$. Agostinho (2015) estimou que a bananicultura é fonte de cerca de $10 \%$ do fósforo dissolvido no rio Ribeira de lguape, entre as cidades de Registro e Iguape, isto é mais um dos indícios de que o PID pode ser advindo do processo de mineração em Cajati. 

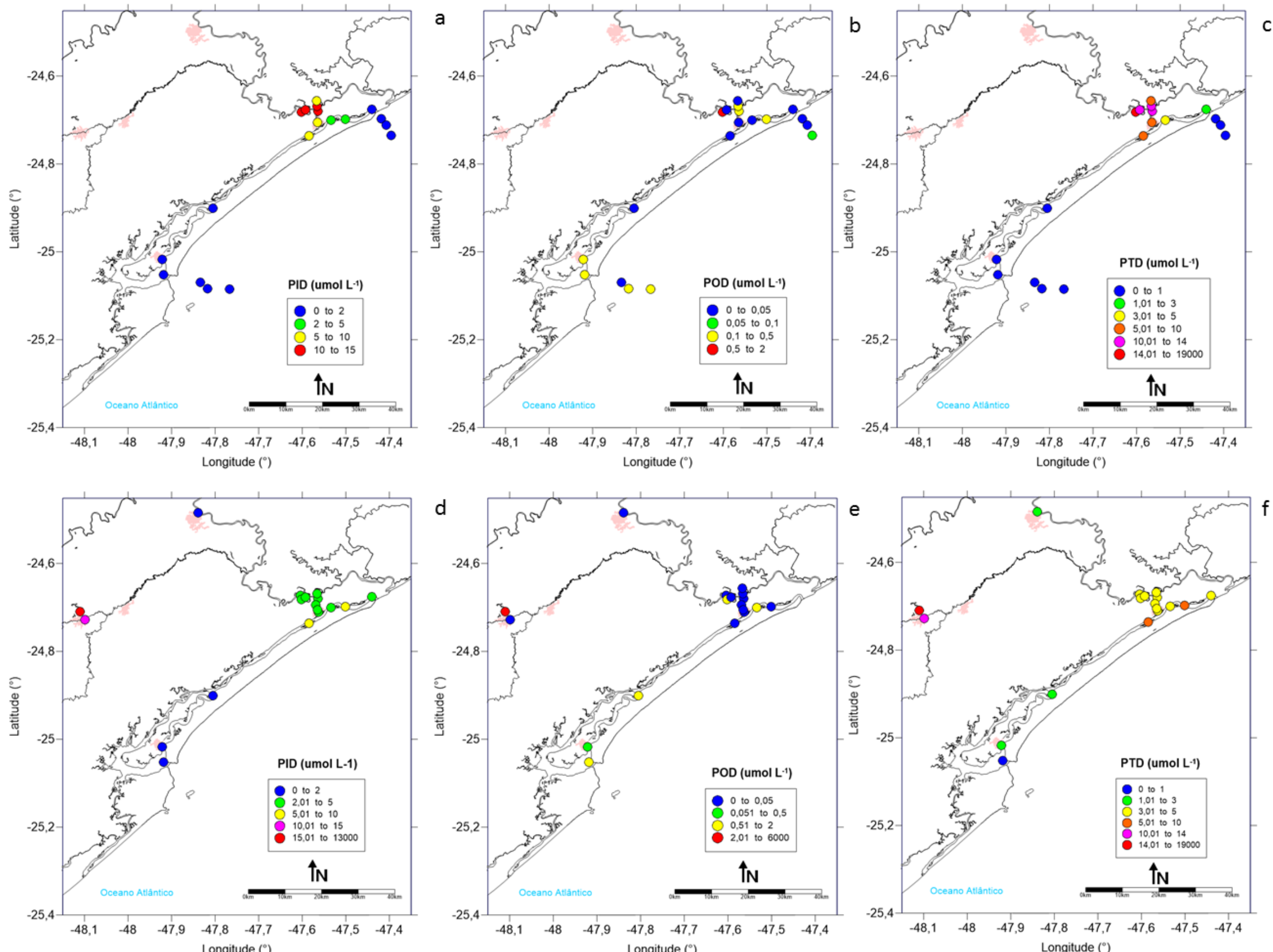

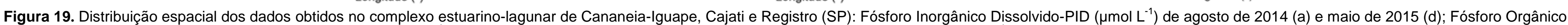
Dissolvido-POD ( $\mu \mathrm{mol} \mathrm{L}^{-1}$ ) de agosto de 2014 (b) e maio de 2015 (e); Fósforo Total Dissolvido-PTD ( $\mu$ mol L-1) de agosto de 2014 (c) e maio de 2015 (f). 
a

b
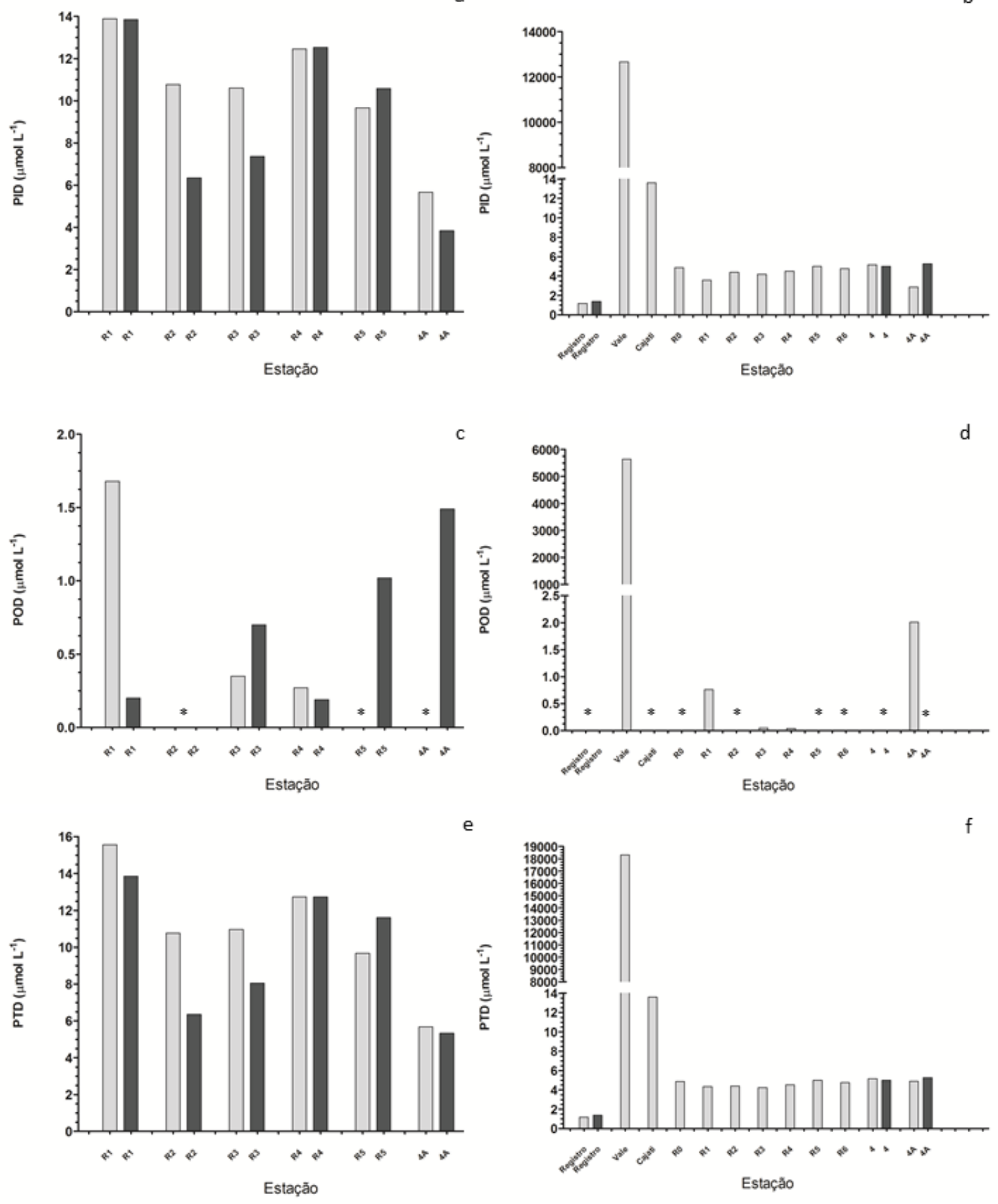

e

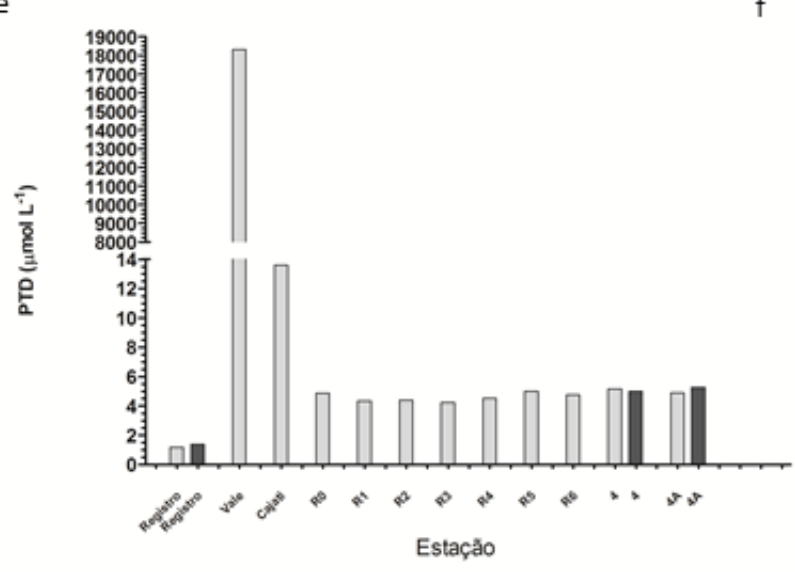

$\square$ Superficie $\square$ Fundo * $<$ LD

Figura 20. Distribuição espacial dos dados coletados nos rios Guaraú, Ribeira de Iguape e canal do Valo Grande (SP): Fósforo Inorgânico Dissolvido-PID ( $\mu \mathrm{mol} \mathrm{L}^{-1}$ ) de agosto de 2014 (a) e maio de 2015 (b); Fósforo Orgânico Dissolvido-POD ( $\left.\mu \mathrm{mol} \mathrm{L}^{-1}\right)$ de agosto de 2014 (c) e maio de 2015 (d); Fósforo Total Dissolvido-PTD ( $\mu \mathrm{mol} \mathrm{L}^{-1}$ ) de agosto de 2014 (e) e maio de 2015 (f). 
Assim, o complexo estuarino-lagunar de Cananeia-Iguape têm sofrido nos últimos 20 anos, alterações físicas e químicas na água, advindas da inserção de água doce e partículas através do canal do Valo Grande. Estas alterações estão ocorrendo nos teores de salinidade, a água antes salobra (valores $>0,05$ ) atualmente está sob maior influência da água doce (valores $<0,05)$ nas campanhas realizadas neste trabalho, como pôde ser observado nos gráficos das figuras $17 \mathrm{~b}$ e 18c. $\mathrm{O} \mathrm{pH}$ acompanha o padrão de mudança da salinidade, em águas salinas geralmente encontra-se valores $>8,0$, porém com a interferência fluvial os valores encontrados no setor norte estão menores, entre 6,0 e 7,5, considerados de água doce e salobra.

Os nutrientes silício e fósforo possuem comportamentos similares, entram no sistema a partir das águas do rio Ribeira de Iguape via canal do Valo Grande e são diluídos pelo gradiente de salinidade. No geral, os valores de fósforo, no setor norte, estiveram mais elevados em agosto de 2014 (Fig. 21a), do que em maio de 2015 (Fig. 22b), exceto na estação Vale que foi amostrada somente em maio. Além da provável fonte antrópica de fósforo através do rio Jacupiranga, a diferença sazonal nas concentrações de fósforo inorgânico dissolvido pode estar relacionada com a ciclagem do nutriente na coluna d' água, pois neste período a produção primária é limitada pela disponibilidade de luz e o aumento dos processos de remineralização da matéria orgânica, que disponibilizam mais nutrientes na forma inorgânica (BRAGA, 1995).

Como pode ser observada no histograma (Fig. 21a), a concentração de PID é mais elevada no rio Ribeira de Iguape, há uma pequena diminuição deste valor na estação $4 \mathrm{~A}$, que aumenta novamente quando atinge as estações do estuário, com diminuição na estação 1 , devido provavelmente a inserção de água salina pela Barra de Icapara. Entre as estações 5 e 6, provavelmente ocorrem processos biogeoquímicos que diminuem o PID em 6,36 $\mu \mathrm{mol} \mathrm{L}^{-1}$. Em maio de 2015 (Fig. 22b), em comparação ao inverno de 2014, as concentrações de PID são praticamente a metade das encontradas no inverno de 2014. A estação Registro apresentou a menor concentração de PID, indicando que a inserção de $P$ no sistema fluvial ocorre em algum ponto à jusante da cidade de Registro, o valor obtido na estação Cajati nos indica que a fonte de fósforo para o rio Ribeira de Iguape pode ocorrer pelo tributário rio 
Jacupiranga. No caminho percorrido entre as estações Cajati e R0 há a depuração de $8,72 \mu \mathrm{mol} \mathrm{L}^{-1}$ de PID. Nas estações de R0 a R6 os valores não possuem grande variação. Nesta campanha também ocorre uma diminuição de

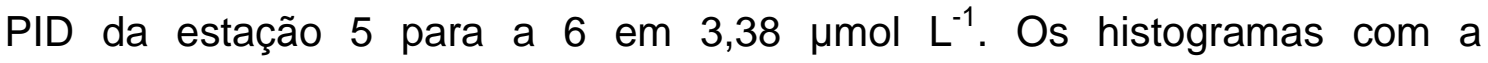
concentrações de POD (Fig. 21a,b) indicam que o PID está em maiores concentrações que o POD.

No geral, os valores de fósforo no complexo estuarino-lagunar de Cananeia-Iguape (SP) encontrados neste trabalho em agosto de 2014 e maio de 2015, estiveram mais elevados do que os encontrados em estuários compostos por rios considerados pristinos (sem grandes interferências antrópicas), como o estuário do rio Jourdan no Mississippi (Estados Unidos Da América) (LIN et al., 2012) e o rio Yukon (GUO et al., 2012) no Canadá. Indicando que há uma necessidade de maior controle dos teores de fósforo encontrados na planície do rio Ribeira de Iguape e do sistema estuarino, visando uma maior preservação do ambiente. 

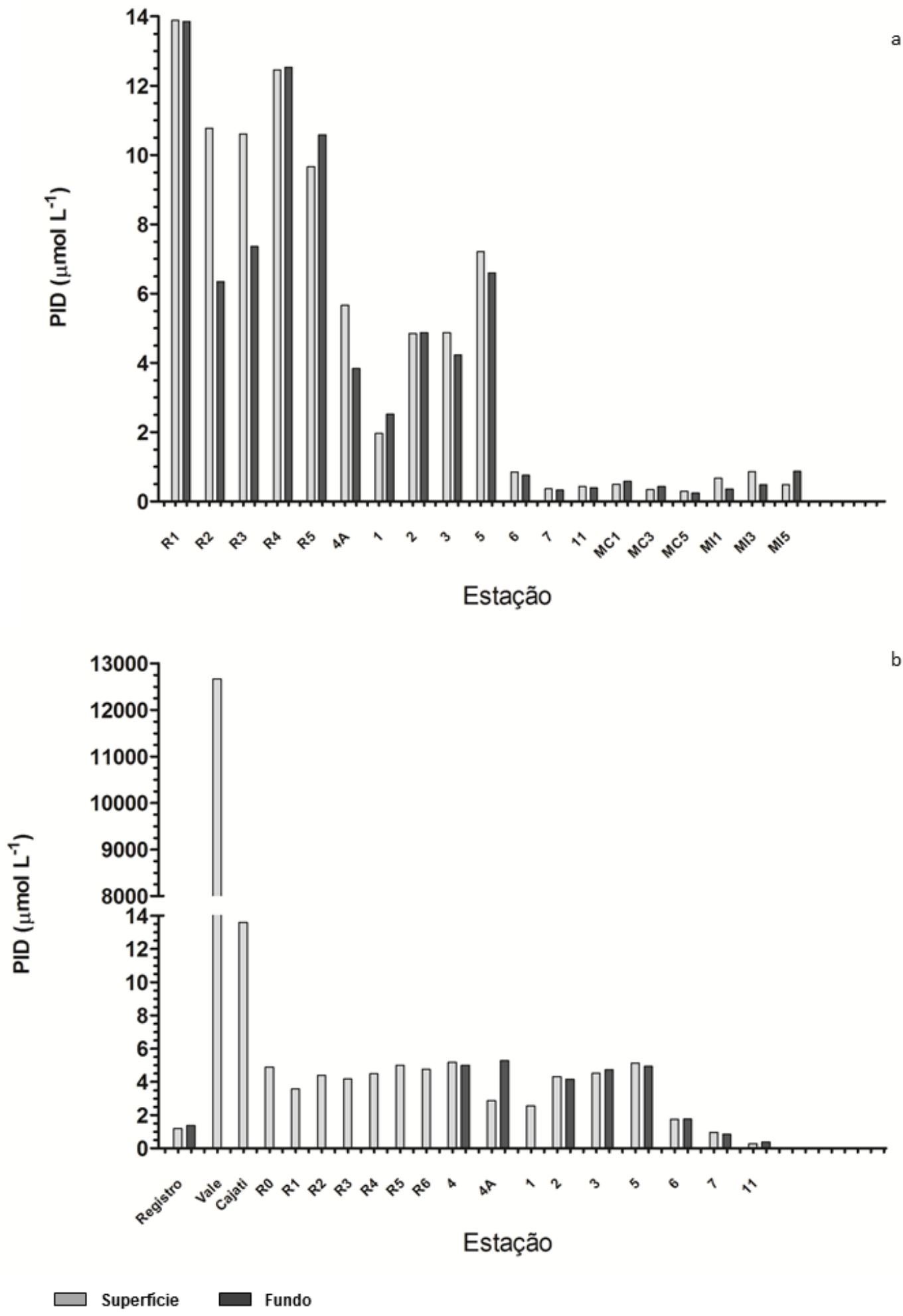

Figura 21. Distribuição espacial dos dados coletados nos rios Guaraú, Ribeira de Iguape e canal do Valo Grande (SP) de Fósforo Inorgânico Dissolvido-PID $\left(\mu \mathrm{mol} \mathrm{L}{ }^{-1}\right)$ de agosto de 2014 (a) e maio de 2015 (b). 


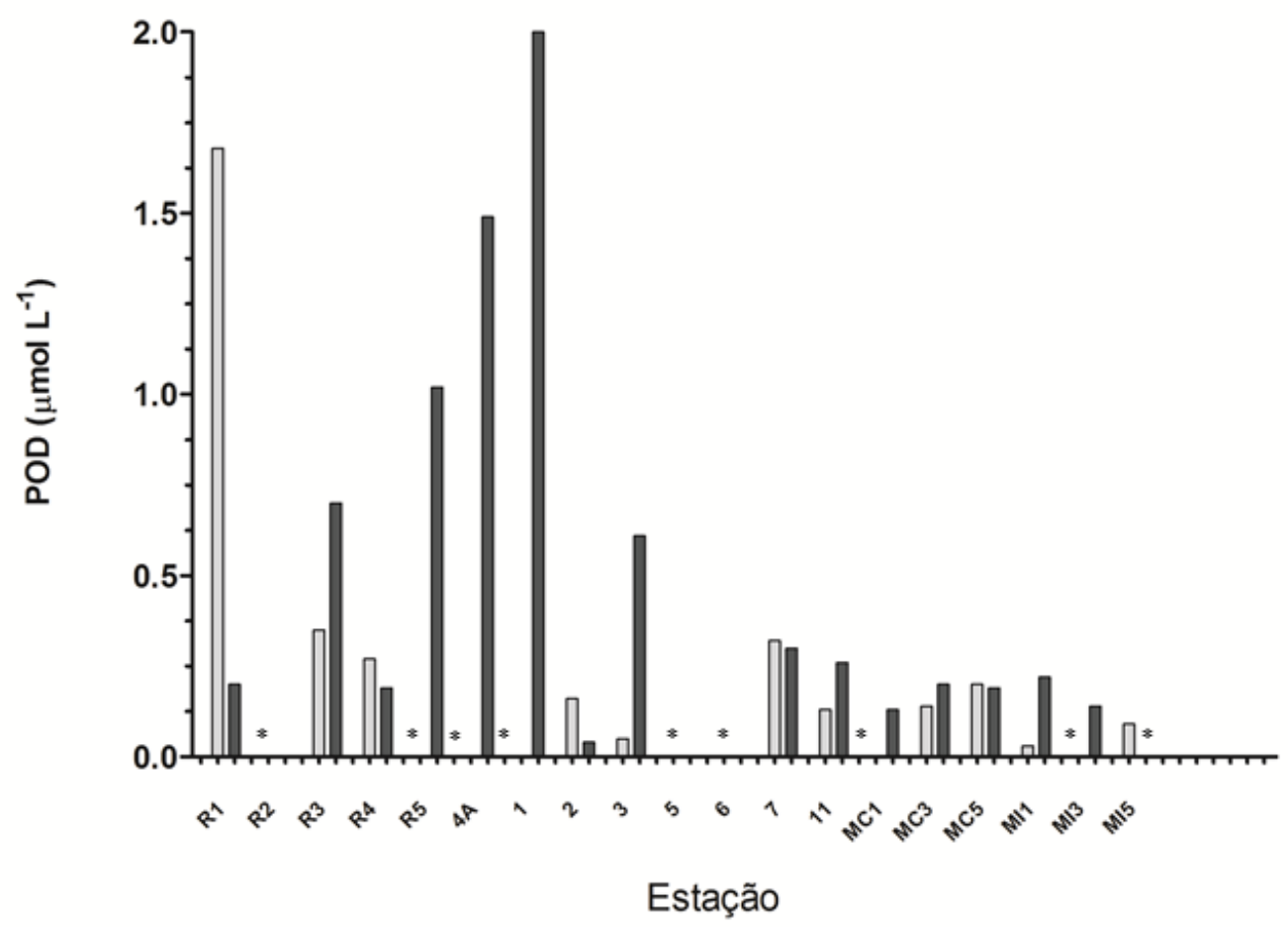

a

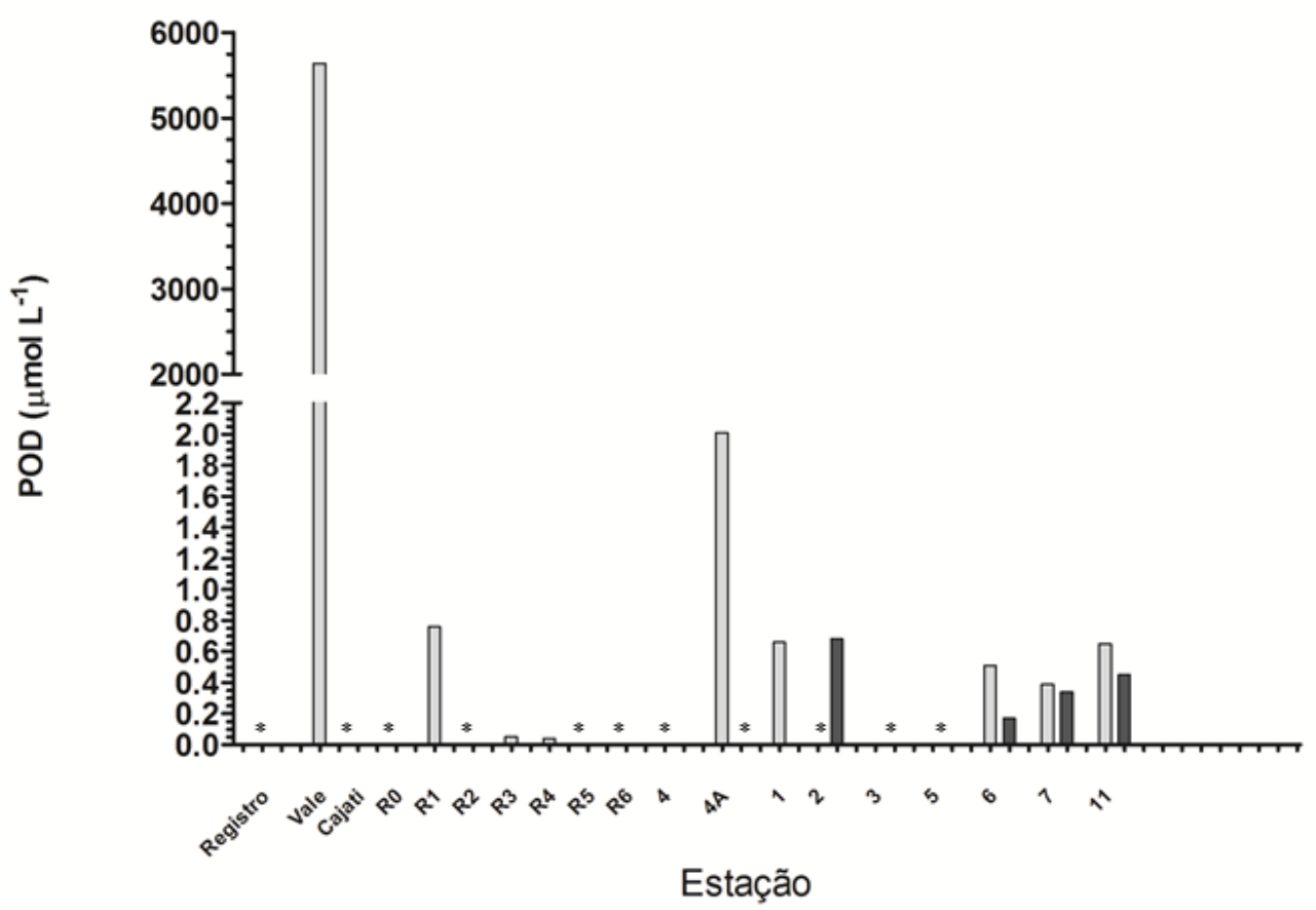

Superficie

Fundo

* $<$ LD

Figura 22. Distribuição espacial dos dados coletados nos rios Guaraú, Ribeira de Iguape e canal do Valo Grande (SP) de Fósforo Orgânico Dissolvido-POD $\left(\mu \mathrm{mol} \mathrm{L}{ }^{-1}\right)$ de agosto de 2014 (a) e maio de 2015 (b). 


\subsection{Material Particulado em Suspensão (MPS) e Material Particulado Orgânico em Suspensão (MPOS)}

Os teores de material particulado em suspensão (MPS) em agosto de 2014 (Fig. 23a) variaram de 7,67 $\mathrm{mg} \mathrm{L}^{-1}$ na estação R4 a 129,56 $\mathrm{mg} \mathrm{L}^{-1}$ na estação $7(5 \mathrm{~m})$, esta coleta foi realizada próxima à estofa de maré vazante 0 que pode ter contribuído à elevação do MPS pela ressuspensão de material de fundo, associado com a saída da água salobra do estuário. Bastos (2014), encontrou teores de MPS entre 4,20 $\mathrm{mg} \mathrm{L}^{-1}$ e $82,75 \mathrm{mg} \mathrm{L}^{-1}$ no inverno de 2012, sendo o valor máximo ligeiramente menor do que o encontrado no atual trabalho, devido ao momento de maré enchente que causou a ressuspensão de material. Eschrique (2011) encontrou uma variação no MPS de 11,23 $\mathrm{mg} \mathrm{L}^{-1}$ e $32,30 \mathrm{mg} \mathrm{L}^{-1}$, no estuário do rio Jaguaribe (CE) sendo que os valores mais elevados estiveram associados ao maior aporte fluvial no sistema. Diferentemente do que ocorreu no rio Jaguaribe (CE), quando se observa o sitema estuarino-lagunar de Cananeia-Iguape (SP) como um todo, ou seja, de sua extensão norte a sul, os valores mais baixos de MPS foram encontrados na região norte, associados à descarga do rio Ribeira de lguape no sistema estuarino, como pode ser observado na figura $26 \mathrm{a}$. Outros trabalhos realizados na mesma área de estudo corroboram com valores menores de MPS junto ao setor norte, em Iguape (MALUF, 2009; ESCHRIQUE, 2011; COELHO, 2011; BASTOS, 2014 e AGOSTINHO, 2015).Esses trabalhos foram realizados com as comportas do Valo Grande abertas, porém Braga (1995) mostra valores de MPS em Cananeia variando de 19,8 $\mathrm{mg} \mathrm{L}^{-1}$ a $33,8 \mathrm{mg} \mathrm{L}^{-1}$, no inverno de 1992, com a comporta fechada. Isso indica que após a abertura das comportas, a quantidade de material particulado em suspensão que atinge o norte do sistema aumentou.

Em maio de 2015 (Fig. 23d) os valores de MPS estiveram entre 3,80 $\mathrm{mg} \mathrm{L}^{-1}$ encontrado na estação Cajati e $61,80 \mathrm{mg} \mathrm{L}^{-1}$ na estação $11(5 \mathrm{~m})$. Nesta campanha houve um aumento no material particulado em suspensão na estação R1, isso pode ter ocorrido devido ao padrão meandrante do rio, que tende a diminuir a velocidade do transporte, aumentando a deposição de partículas no setor convexo do leito do rio, como pode ser observado na figura 11. No outono de 2007 Maluf (2009), encontrou valores entre $45,6 \mathrm{mg} \mathrm{L}^{-1} \mathrm{e}$ 
99,17 $\mathrm{mg} \mathrm{L}^{-1}$ nas estações do setor norte do complexo estuarino-lagunar de Cananeia-Iguape (SP), valores mais elevados dos que o observado neste presente trabalho. No caso do setor sul, os valores variam entre $10,0 \mathrm{mg} \mathrm{L}^{-1} \mathrm{e}$ $59,20 \mathrm{mg} \mathrm{L}^{-1}$.

Considerando apenas as estações do rio, nas duas campanhas, foram encontrados os menores valores de MPS, apesar da turbidez ter sido sempre mais elevada, isso se deve a qualidade do material particulado em suspensão que é muito fino, como já apontado por Braga em suas pesquisas (com. Pessoal). No setor sul do sistema os valores de material particulado em suspensão foram mais elevados e tiveram distribuição similar à turbidez, isto pode indicar uma diferença no tamanho e qualidade das partículas em suspensão entre os dois setores do sistema.

Segundo Becegato (2007), os sedimentos em suspensão na região norte do complexo estuarino-lagunar de Cananeia-Iguape (SP) são predominantemente siltosos, podendo conter também areias finas e argilas, seu transporte ocorre por via fluvial. Enquanto no setor sul, o material particulado em suspensão está relacionado às frações mais grossas, silte e areia fina, provenientes dos processos de ressuspensão de sedimentos de fundo, advindos do movimento da maré enchente e aos processos de erosão (ESCHRIQUE , 2011) atuantes nas margens da Ilha Comprida, principalmente próximo a Barra de Cananeia.

O material particulado orgânico em suspensão (MPOS) constituiu parcela do MPS por isso geralmente apresentam comportamento similar, seus valores em agosto de 2014 (Fig. 23b) variaram entre $1,00 \mathrm{mg} \mathrm{L}^{-1}$ na estação R4 (Om) e 18,44 $\mathrm{mg} \mathrm{L}^{-1}$ na estação 7 (5m). Em porcentagem, o MPOS (Fig. 23c) correspondeu de $9,74 \%$ a $31,72 \%$ do MPS, portanto nessa campanha, considerando todas as estações de coleta, a fração inorgânica do MPS predominou em relação MPOS. Berbel (2008) observou valores de MPOS, no período de inverno, com variação entre $0,23 \mathrm{mg} \mathrm{L}^{-1}$ e $4,37 \mathrm{mg} \mathrm{L}^{-1}$, enquanto no presente trabalho foram encontrados valores maiores, principalmente no setor sul do sistema.

Em maio de 2015 (Fig. 23e), as concentrações de MPOS foram de 0,33 $\mathrm{mg} \mathrm{L}^{-1}$, nas estações $\mathrm{R} 4$ e R6, a $8,5 \mathrm{mg} \mathrm{L}^{-1}$ na estação 2 , em porcentagem, o maior valor correspondeu a $27,59 \%$ do MPS (Fig. 23f), havendo novamente a 
predominância do material inorgânico. O padrãode distribuição do MPOS foi bastante semelhante a do MPS, mostrando diferenças entre os dois setores do sistema estuarino.

No inverno de 2014, as concentrações de MPOS foram mais elevadas que no outono de 2015, exceto no caso da estação Vale (localizada no planalto), que corresponde a um córrego de rejeito da mineração na cidade de Cajati.

De um modo geral, a diferença sazonal (outono-inverno) observada no complexo estuarino-lagunar de Cananeia-Iguape (SP), pode ter fundamento no intenso processo de remineralização que se inicia no outono sobre a matéria orgânica procedente do período de maior produção primária (verão) e a consequente decomposição e encerramento de ciclo de muitos organismos (BRAGA, 1995). 

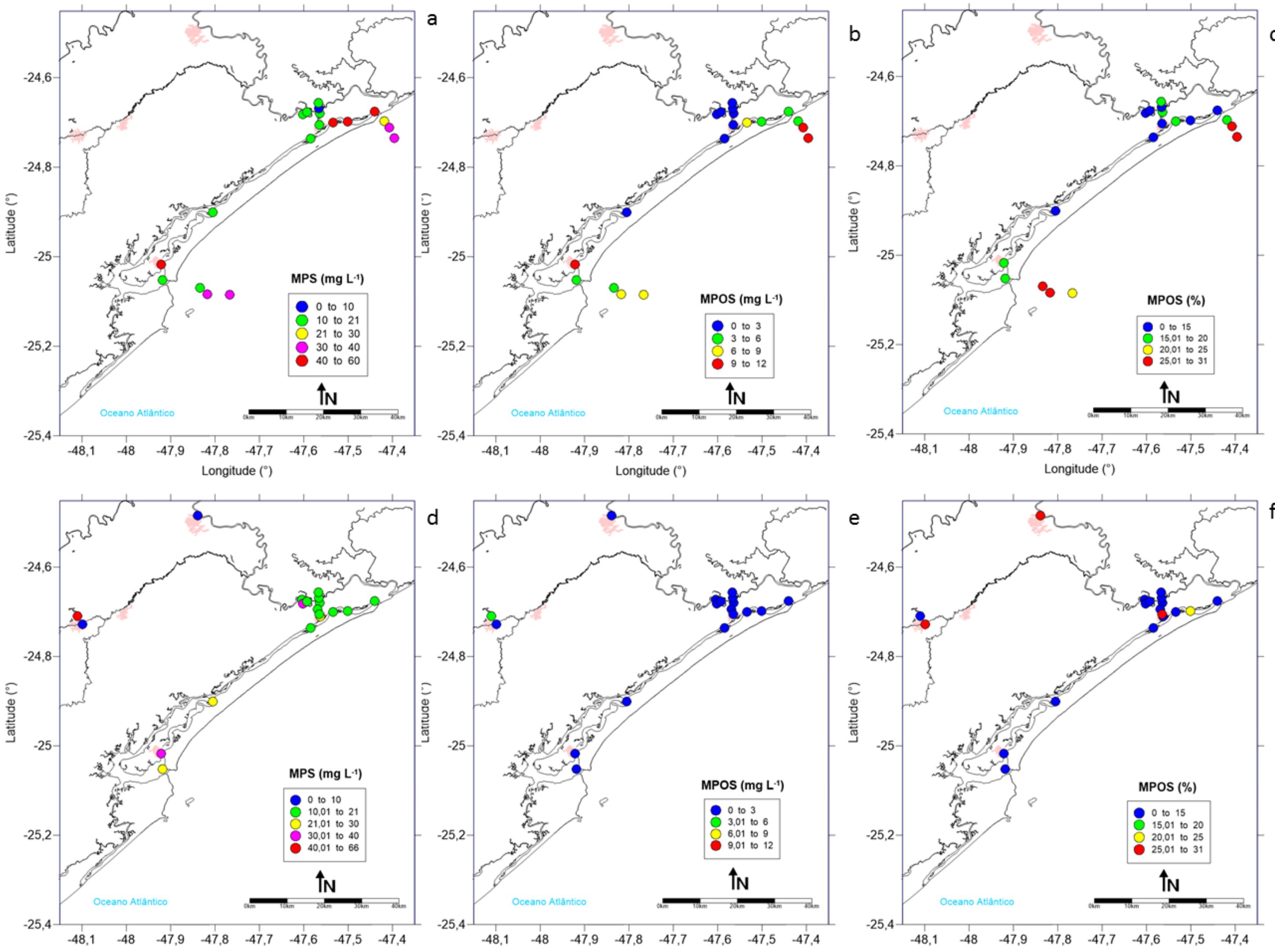

Figura 23. Distribuição espacial dos dados obtidos no sistema estuarino-lagunar de Cananeia-lguape, Cajati e Registro (SP): material particulado em suspensão (MPS) (mg $\mathrm{L}^{-1}$ ) de agosto de 2014 (a) e maio de 2015 (d); material particulado orgânico em suspensão (MPOS) (mg L-1) de agosto de 2014 (b) e maio de 2015 (e); material particulado orgânico em suspensão (MPOS) (\%) de agosto de 2014 (c) e maio de 2015 (f). 


\subsection{Fósforo Total Particulado em Suspensão (PTP), Fósforo Inorgânico Particulado em Suspensão (PIP) e Fósforo Orgânico Particulado em Suspensão (POP) na coluna d'água}

$\mathrm{Na}$ figura 27 pode-se observar a distribuição espacial dos teores de fósforo particulado em suspensão nas diferentes fases: fósforo particulado total em suspensão (PTP), fósforo inorgânico particulado em suspensão (PIP) e fósforo orgânico particulado em suspensão (POP).

O fósforo total particulado em suspensão (PTP) na coluna d' água também corresponde a uma parcela do MPS total. Este parâmetro em agosto de 2014 (Fig. 24a) apresentou concentrações entre $3,89 \mu \mathrm{mol} \mathrm{g}^{-1}$ na estação MC5 (10 m) a 140,88 $\mu \mathrm{mol} \mathrm{g}^{-1}$ na estação R5 (5 m), sendo que os valores mais altos foram encontrados no setor norte do sistema estuarino-lagunar, sob a maior influência do rio Ribeira de Iguape. Em maio de 2015 (Fig. 24d) a variação foi de 13,53 $\mu \mathrm{mol} \mathrm{g}{ }^{-1}$ na estação 7 (5 m) a 791,26 $\mu \mathrm{mol} \mathrm{g}{ }^{-1}$ na estação Vale. Nesta campanha os valores mais altos também foram encontrados na área de influência da água do rio, destacando-se que na estação Registro o valor de PTP é o menor dentre as amostras do rio.

O fósforo inorgânico particulado em suspensão (PIP) apresentou distribuição semelhante a do PTP, em agosto de 2014 (Fig. 24b), sendo que o parâmetro variou entre $1,28 \mu \mathrm{mol} \mathrm{g}^{-1}$ na estação MC5 (10 m) e 51,30 $\mu \mathrm{mol} \mathrm{g}^{-1}$ na estação $5(3 \mathrm{~m})$, porém todas as estações sob influência do rio tiveram valores elevados, enquanto em direção às Barras de Cananeia e Icapara os valores foram mais baixos destacando-se a estação MC01 com aumento nas concentrações de PIP em 5 e $8 \mathrm{~m}$ de profundidade, podendo neste ponto haver processo evidente de deposição de material fino. No caso de maio de 2015 (Fig. 24e), os teores estiveram entre $5,01 \mu \mathrm{mol} \mathrm{g}^{-1}$ na estação $11(0 \mathrm{~m}) \mathrm{e}$ um máximo muito acentuado de 429,24 $\mu \mathrm{mol} \mathrm{g}^{-1}$ na estação Vale.

As concentrações de fósforo orgânico particulado (POP) obtidas em agosto de 2014 (Fig. 24c) estiveram entre 2,39 $\mu \mathrm{mol} \mathrm{g}^{-1}$ na estação MC1 (5 m) e 104,12 $\mu \mathrm{mol} \mathrm{g}^{-1}$ na estação R5 (5 m), nesta campanha o POP constituiu de $31,75 \%$ a $85,22 \%$ do PTP. Em maio de 2015 (Fig. 24f) observou-se que os valores variaram entre 3,72 na estação $4(8 \mathrm{~m})$ e 362,02 $\mu \mathrm{mol} \mathrm{g}^{-1}$ na estação Vale. 
De acordo com Lin et al., (2013) no estuário do rio Jiulong, foram

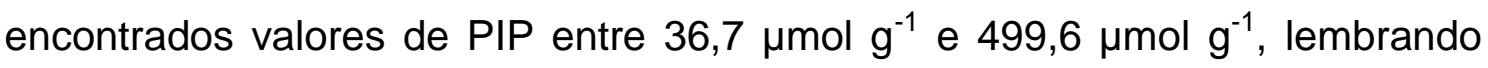
que este estuário é altamente impactado por ações antrópicas. No trabalho desenvolvido no complexo estuarino-lagunar de Cananeia-Iguape (SP), os valores mínimos e os máximos de PIP nas duas campanhas foram inferiores aos encontrados por Lin et al. (2013). No caso do POP, a variação foi de 7,7 $\mu \mathrm{mol} \mathrm{g}^{-1}$ a $42,7 \mu \mathrm{mol} \mathrm{g}^{-1}$, concentrações menos elevadas do que as encontradas no trabalho atual podem ser resultado de diferentes fontes e intensidade de inserção do material fosfatado.

No estuário do rio Jourdan (Estados Unidos da América), Lin et al. (2012) encontraram valores mais baixos, tanto de PIP, quanto de POP. O PIP relatado está entre $2,75 \mu \mathrm{mol} \mathrm{g}{ }^{-1}$ e $35,95 \mu \mathrm{mol} \mathrm{g}^{-1}$. No rio Jourdan (Estados Unidos da América) e no rio Wolf foram encontrados valores mais baixos, de $2,75 \mu \mathrm{mol} \mathrm{g} \mathrm{g}^{-1}$ a $9,93 \mu \mathrm{mol} \mathrm{g}^{-1}$ respectivamente, sendo que em todas as estações do rio Ribeira de Iguape, houve uma concentração de PIP mais elevada em aproximadamente sete vezes do que as encontradas no rio Jourdan (Estados Unidos da América). No entanto, em todos os pontos de coleta no estuário do rio Jourdan (Estados Unidos da América), o POP ocorre em maiores concentrações que o PIP, entre $34,88 \mu \mathrm{mol} \mathrm{g}{ }^{-1}$ e $90,38 \mu \mathrm{mol} \mathrm{g}^{-1}$. O complexo estuarino-lagunar de Cananeia-Iguape apresenta valores de POP, menos elevados que os encontrados por Lin et al. (2012).

Entre as duas campanhas houve uma diferença entre os valores de PIP e POP no complexo estuarino-lagunar de Cananeia-Iguape (SP), provavelmente advinda da ação da sazonalidade nos processos biogeoquímicos. Em agosto de 2014, as estações no rio Ribeira de lguape (R1R5) e a estação 4A (localizada no canal do Valo Grande) o POP foi mais elevado que o PIP; na superfície das estações 1e 2 o PIP foi mais elevado que o POP, porém no fundo esse padrão é invertido; na estação 3 e 5 os valores de PIP, na superfície, foram menos elevados que os de POP. Provavelmente, no fundo ocorreu uma inversão, possivelmente devido a ressuspensão do material de fundo, causado pela maré. As estações 6 e 7, sob menor influência do rio Ribeira de Iguape, na coluna d' água inteira o PIP foi inferior ao POP. Nas estações na plataforma (MC1-MC5 e Ml1-M15) os valores de POP foram superiores aos de PIP, exceto na estação MC1 a $5 \mathrm{~m}$ de profundidade. Estes 
valores podem ter contribuição da fração de matéria orgânica viva em suspensão (fitoplâncton).

Em maio de 2015, na estação Registro os valores de POP foram mais elevados que o PIP. No entanto, nas demais estações sob influência fluvial as concentrações de PIP foram mais elevadas que as de POP. Ao adentrar ao sistema esta relação permanece, exceto na estação $2(5 \mathrm{~m})$, na $7(0 \mathrm{~m}$ e $10 \mathrm{~m})$ e na 11 (0 m e $5 \mathrm{~m})$. Essa inversão pode ter ocorrido, devido a sedimentação junto ao fundo de fósforo inorgânico ao longo da coluna d'água.

Assim, os valores de $\mathrm{P}$ na coluna d'água e os parâmetros ambientais associados a ele somados ao silicato (Tabs. 5;6), evidenciam os setores do sistema hídrico estudado, atribuindo uma situação bastante afetada por formas inorgânicas de $\mathrm{P}$, sobretudo PID introduzida pelo Rio Ribeira de Iguape no setor norte, via Valo Grande. O processo de diluição do nutriente ocorre em direção ao sul do sistema e à plataforma, sendo que a sazonalidade afeta 0 comportamento entre as formas, sobretudo devido às maiores precipitações pluviométricas, produção primária, processos de fotossíntese, precipitação e sorção/dessorção. A fonte de fosfato no planalto, ligada à Cajati também ficou evidente. As formas orgânicas não foram tão intensas e a fração associada ao MPS mostrou maior contribuição inorgânica dentro do sistema junto ao setor norte e rio, associada a fração fina de material de origem terrestre. No caso do setor sul e na área marinha, os valores de MPS e seu conteúdo em P orgânico estiveram ligados aos organismos, detritos orgânicos e à granulometria do material particulado em suspensão. 

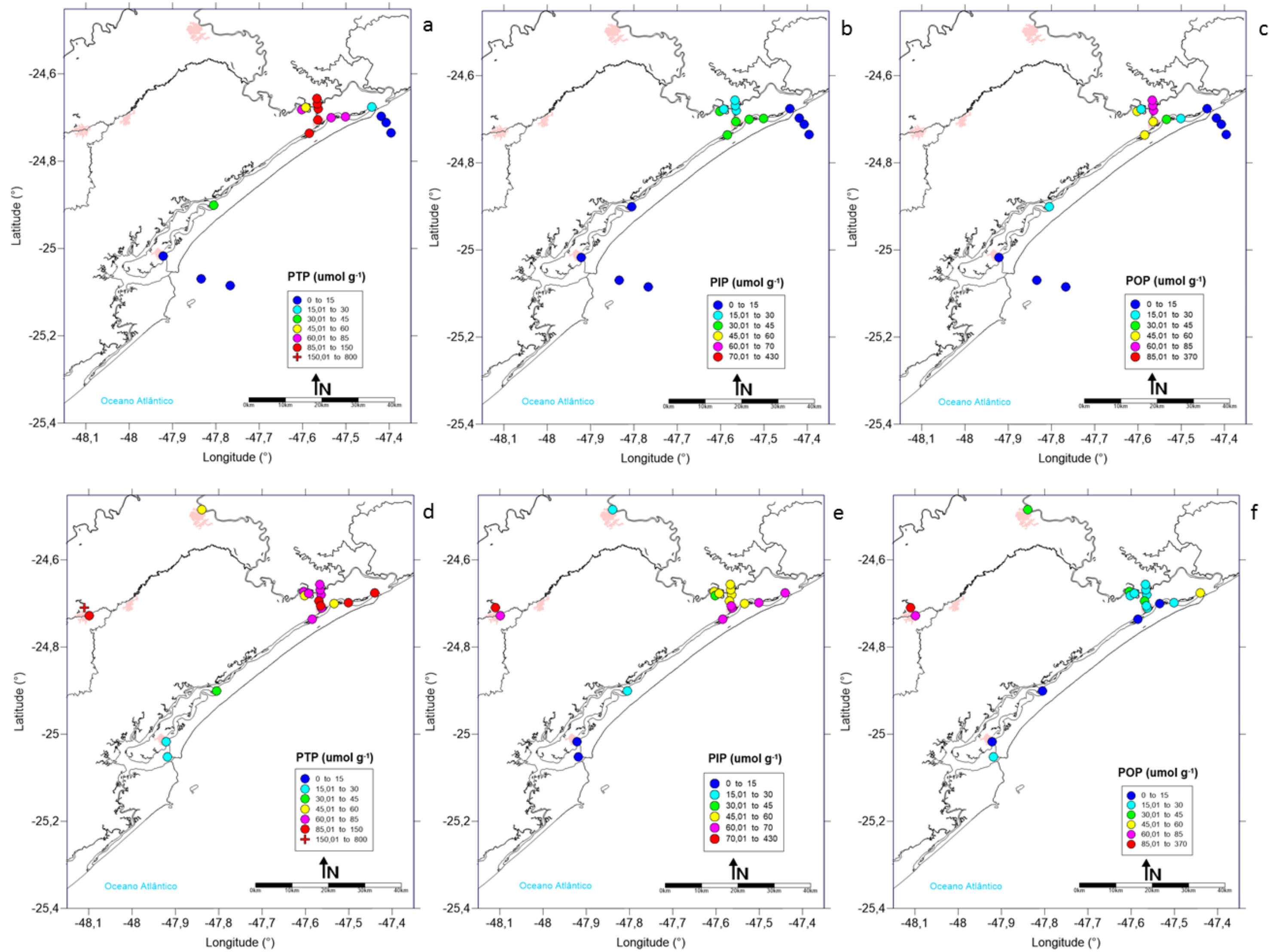

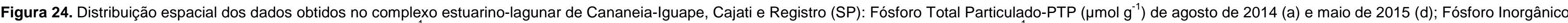
Particulado-PIP ( $\mu \mathrm{mol} \mathrm{g}^{-1}$ ) de agosto de 2014 (b) e maio de 2015 (e); Fósforo Orgânico Particulado-POP ( $\mu$ mol g ${ }^{-1}$ ) de agosto de 2014 (c) e maio de 2015 (f). 
Tabela 5. Quadro sinóptico na situação do sistema em Agosto de 2014.

\begin{tabular}{|c|c|c|c|c|c|c|c|c|c|c|}
\hline Setores de Coleta & Variação & Temp. & Sal. & OD & $\mathrm{pH}$ & Turb. & Si. & PID & POD & PTD \\
\hline \multirow{2}{*}{$\begin{array}{l}\text { Rio Ribeira de lguape } \\
\text { (R1-R5) }\end{array}$} & Mínimo & 21,6 & 0,03 & 5,35 & 7,34 & 8,78 & 210,6 & 6,35 & $<\mathrm{LD}$ & 6,35 \\
\hline & Máximo & 22,3 & 0,05 & 5,58 & 7,67 & 13,7 & 231,25 & 13,89 & 1,68 & 13,89 \\
\hline \multirow{2}{*}{$\begin{array}{c}\text { Sistema Estuarino } \\
\text { Setor Norte (1-5) }\end{array}$} & Mínimo & 20,8 & 0,08 & 5,36 & 7,61 & 7,4 & 77,36 & 1,97 & $<L D$ & 1,97 \\
\hline & Máximo & 22,8 & 16,25 & 5,86 & 8,19 & 70,8 & 208,76 & 7,21 & 2,00 & 7,21 \\
\hline \multirow{2}{*}{$\begin{array}{l}\text { Sistema Estuarino } \\
\text { Setor Sul (6-11) }\end{array}$} & Mínimo & 20,7 & 10,47 & 5,05 & 7,73 & 1,58 & 5,62 & 0,27 & $<L D$ & 0,56 \\
\hline & Máximo & 22,1 & 32,21 & 5,43 & 8,25 & 14,4 & 29,62 & 0,85 & 0,38 & 0,85 \\
\hline \multirow{2}{*}{$\begin{array}{l}\text { Barra de Cananeia } \\
\text { (MC1-MC3) }\end{array}$} & Mínimo & n.d. & 28,92 & 4,49 & n.d. & 0,4 & 3,09 & 0,24 & $<L D$ & 0,42 \\
\hline & Máximo & n.d. & 34,16 & 5,79 & n.d. & 4,83 & 9,82 & 0,50 & 0,24 & 0,70 \\
\hline \multirow{2}{*}{$\begin{array}{l}\text { Barra de lcapara } \\
\text { (MI1-MI3) }\end{array}$} & Mínimo & n.d. & 31,48 & 4,64 & n.d. & 1,01 & 4,62 & 0,29 & $<L D$ & 0,51 \\
\hline & Máximo & n.d. & 33,92 & 6,77 & n.d. & 3,85 & 15,19 & 0,87 & 0,22 & 0,87 \\
\hline
\end{tabular}

n.d. = não determinado $<L D=$ menor que o limite de detecção

Tabela 6. Quadro sinóptico na situação do sistema em Maio de 2015

\begin{tabular}{|c|c|c|c|c|c|c|c|c|c|c|}
\hline Setores de Coleta & Variação & Tem. & Sal. & OD & pH & Turb. & Si. & PID & POD & PTD \\
\hline \multirow{2}{*}{ Registro } & Mínimo & 22,0 & 0,03 & 5,37 & 7,224 & 16,60 & 188,24 & 1,19 & $<\mathrm{LD}$ & 22,03 \\
\cline { 2 - 11 } & Máximo & 22,3 & 0,04 & 5,81 & 7,361 & 18,60 & 197,55 & 1,38 & $<\mathrm{LD}$ & 22,34 \\
\hline Vale & $\begin{array}{c}\text { Valor } \\
\text { único }\end{array}$ & 23,9 & 0,00 & 0,75 & 5,331 & $>1.000$ & 11,27 & $12.665,44$ & $5.639,03$ & $18.304,47$ \\
\hline Cajati & $\begin{array}{c}\text { Valor } \\
\text { único }\end{array}$ & 20,5 & 0,05 & 5,97 & 7,211 & 7,74 & 209,31 & 13,60 & $<\mathrm{LD}$ & 13,60 \\
\hline $\begin{array}{c}\text { Rio Ribeira de } \\
\text { Iguape } \\
\text { (R0-R6) }\end{array}$ & Mínimo & 21,5 & 0,03 & 4,85 & 6,98 & 13,50 & 100,98 & 3,57 & $<\mathrm{LD}$ & 4,23 \\
\cline { 2 - 11 } & Máximo & 21,8 & 0,04 & 5,30 & 7,04 & 21,10 & 211,76 & 5,00 & 0,76 & 5,00 \\
\hline $\begin{array}{c}\text { Sistema Estuarino } \\
\text { Setor Norte } \\
(1-5)\end{array}$ & Mínimo & 21,4 & 0,03 & 4,65 & 6,95 & 11,00 & 152,45 & 2,56 & $<\mathrm{LD}$ & 3,22 \\
\cline { 2 - 11 } & Máximo & 22,6 & 4,70 & 5,04 & 7,21 & 29,9 & 250,49 & 5,28 & 2,01 & 5,28 \\
\hline $\begin{array}{c}\text { Sistema Estuarino } \\
\text { Setor Sul } \\
\text { (6-11) }\end{array}$ & Mínimo & 22,8 & 7,90 & 4,28 & 7,43 & 3,77 & 21,37 & 0,28 & 0,17 & 0,82 \\
\cline { 2 - 10 } & Máximo & 23,2 & 25,81 & 5,28 & 7,95 & 9,68 & 129,90 & 1,76 & 0,65 & 2,26 \\
\hline
\end{tabular}

$\angle \mathrm{LD}=$ menor que 0 limite de detecção

\subsection{Clorofila-a}

A distribuição das concentrações de clorofila-a, principal indicador da produtividade primária, podem ser observadas nas figuras 24 e 25 . No inverno de 2014 (Fig. 25), os valores variaram de $0,38 \mathrm{mg} \mathrm{m}^{-3}$, na estação MC5 a 10m, a $19,29 \mathrm{mg} \mathrm{m}^{-3}$, no fundo da estação 5 , os demais pontos apresentaram valores abaixo de $14 \mathrm{mg} \mathrm{m}^{-3}$. Dentro do sistema o mínimo foi de $4,35 \mathrm{mg} \mathrm{m}^{-3}$ no fundo da estação 6. Já no outono de 2015 (Fig. 26) os valores desse pigmento foram menores, variando de $0,41 \mathrm{mg} \mathrm{m}^{-3}$, na estação $\mathrm{R} 0$, a $11,37 \mathrm{mg} \mathrm{m}^{-3}$, na estação 6 a $5 \mathrm{~m}$ de profundidade. As maiores concentrações de clorofila-a 
foram encontradas no inverno, principalmente no setor norte do sistema, podem estar relacionadas com a alta disponibilidade de nutrientes (PID aproximadamente $10 \mathrm{mg} \mathrm{m}^{-3}$ ) e valores menores de turbidez; na estação 5 a turbidez esteve em torno de 7 NTU e no inverno, enquanto no outono foi de aproximadamente 20 NTU.

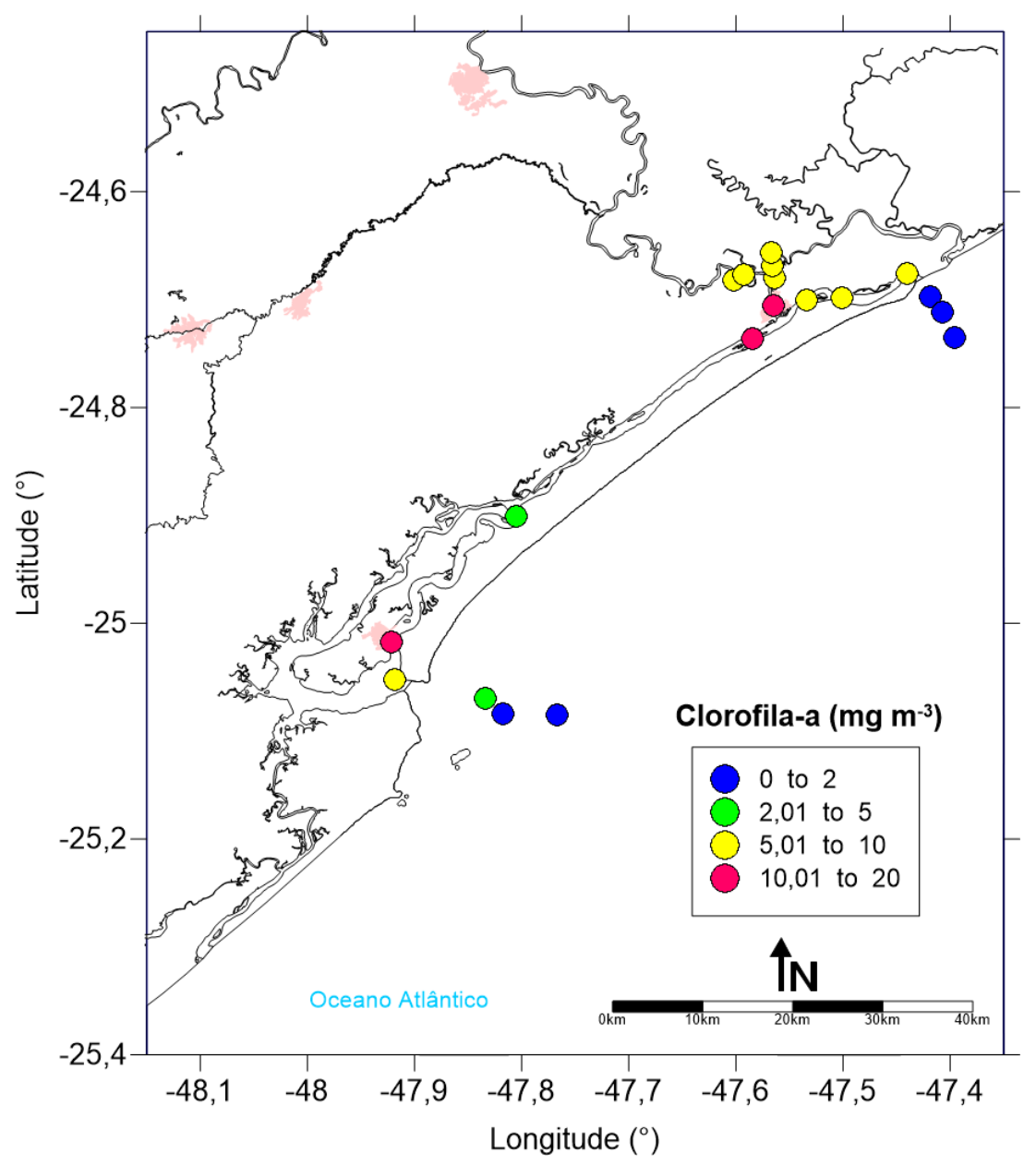

Figura 25. Distribuição espacial dos dados de clorofila-a $\left(\mathrm{mg} \mathrm{m}^{-3}\right)$ coletados no rio Ribeira de Iguape, complexo estuarino-lagunar de Cananeia-Iguape, Barras de Cananeia e Icapara (SP), agosto de 2014. 


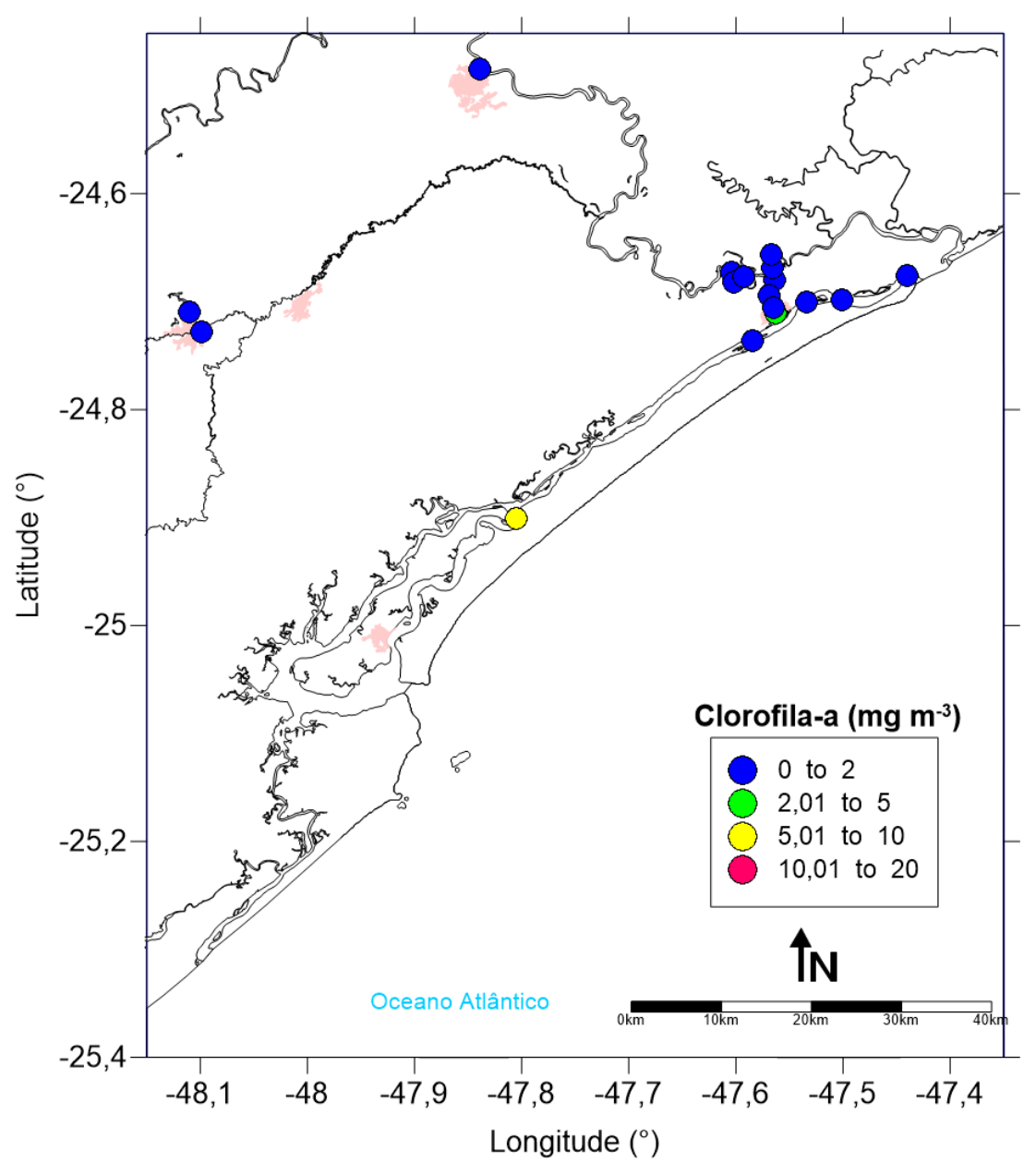

Figura 26. Distribuição espacial dos dados de clorofila-a $\left(\mathrm{mg} \mathrm{m}^{-3}\right)$ coletados no rio Ribeira de Iguape, complexo estuarino-lagunar de Cananeia-Iguape, Barras de Cananeia e Icapara (SP), maio de 2015.

De uma forma geral, os valores de clorofila-a estiveram próximos aos encontrados por outros autores no complexo estuarino-lagunar de CananeiaIguape. Eschrique (2011) e Coelho (2011) encontraram, em agosto de 2009, um mínimo de 1,47 $\mathrm{mg} \mathrm{m}^{-3}$, em Cananeia, e um máximo de $9,51 \mathrm{mg} \mathrm{m}^{-3} \mathrm{em}$ Iguape. Bastos (2014) observou, em agosto de 2012, uma variação de 0,04 mg $\mathrm{m}^{-3}$, no Canal do Ararapira, a 12,89 $\mathrm{mg} \mathrm{m}^{-3}$, na estação 3. 


\subsection{Parâmetros Sedimentares de Amostras Superficiais das Estações do Rio Ribeira de Iguape, Rio Guaraú, Sistema Estuarino-Lagunar de Cananeia-Iguape, Barra de Icapara e Barra de Cananeia (SP)}

\subsubsection{Matéria Orgânica (MO)}

Como pode ser observado nas figuras 27 e 29, estão representados os teores de matéria orgânica, carbonato biodetríticos e granulometria. Em agosto de 2014 (Tab. 7; Fig.27), os teores de MO variaram entre 0,13\% e 14,20\%. Nas amostras do rio Ribeira de Iguape, a matéria orgânica esteve presente em maior porcentagem nas estações R1 e R2, com 3,68\% e $1,37 \%$ respectivamente, nas demais os valores estão abaixo de 1,0\%. No entanto, no corpo estuarino os maiores teores são observados nas estações 7 (2,33\%) e 2 $(4,48 \%)$, nas demais os valores estão abaixo de $1,0 \%$. Na plataforma, foi encontrado o maior teor de $\mathrm{MO}$ na estação MC1 (14,20\%), as demais estações estão com valores acima de 1,0\%.

Em maio de 2015 (Tab. 7; Fig. 29), os teores de matéria orgânica estiveram entre $0,07 \%$ na estação 3 e 9,40\% na estação R5. No rio, observaram-se os maiores teores de $\mathrm{MO}$, entre $5,45 \%$ na estação R3 e 9,40\% na estação R5, com relação aos dados de inverno deste trabalho. Nas estações de 1 à 11 , os valores foram menos elevados que no rio, com destaque às estações $4(2,93 \%)$ e $7(2,73 \%)$, na estação 3 foi encontrado o menor teor de MO.

O padrão de distribuição de $\mathrm{MO}$ deste trabalho, coincide com o encontrado por Berbel (2008) e Aguiar (2005), que obtiveram no Mar de Cananeia valores de MO entre $0,46 \%$ e 4,00\%. Coelho (2011), com uma malha amostral semelhante à deste trabalho, apresentou uma variação de $\mathrm{MO}$ entre 0,43\% e 14,80\%, e indica que os maiores valores estão associados à amostras com maiores teores de sedimentos finos (silte e argila). Padrão muito semelhando ao encontrado por este trabalho.

\subsubsection{Carbonato biodetríticos $\left(\mathrm{CaCO}_{3}\right)$}

O teor de carbonato biodetrítico acompanhou em algumas estações a distribuição da matéria orgânica. No inverno de 2014 (Tab. 7, Fig.27), houve variação entre $0,40 \%$ na estação 5 a $20 \%$ na estação 7 , todos os valores estiveram abaixo de $30 \%$, sendo caracterizados portanto como sedimentos 
litoclásticos (Larssoneur et al., 1982), Berbel (2008) e Coelho (2011), também encontraram este padrão. No rio, a variação ocorreu entre $1,57 \%$ na estação R2 e 3,64\% na estação R1. No estuário, os valores foram um pouco mais elevados, entre 3,40\% na estação 2 e 3,64\% na estação 7, estas duas estações também tiveram presença de matéria orgânica em sua composição. Nas estações de plataforma os valores encontrados foram entre 2,07\% na estação MI3 e 7,20\% na estação MC1, esta última também apresentou o maior valor de MO.

Coelho (2011), em trabalho realizado com uma malha amostral semelhante à deste, encontrou, em agosto de 2009, variações de $\mathrm{CaCO}_{3}$ entre 0,0\% e $7,5 \%$ com os valores mais altos no setor sul do sistema estuarinolagunar de Cananeia-Iguape, corroborando com os dados apresentados neste trabalho.

Em maio de 2015 (Tab. 7; Fig. 29), o teor de carbonato biodetrítico variou entre $0,23 \%$ na estação 6 e $87,15 \%$ na estação Vale, esta última amostra foi coletada em um córrego que deságua nas lagoas de decantação da mineração da fluorapatita em Cajati (SP), este material provavelmente é o rejeito classificado como fosfogesso ou sulfato de cálcio di-hidratado $\left(\mathrm{Ca}_{3} \mathrm{PO}_{4} \cdot \mathrm{H}_{2} \mathrm{O}\right)$. Segundo Das Chagas (2014), aproximadamente $30 \%$ do fosfogesso é composto por óxido de cálcio $(\mathrm{CaO})$, por este motivo esta amostra apresenta altos teores de carbonato biodetrítico. No rio, os valores estiveram entre $0,87 \%$ na estação Registro e $1,80 \%$ na estação $R$, nesta campanha os teores estão cerca de duas vezes menores que no inverno de 2014. Nas estações de 1 a 11, os valores foram mais elevados, com uma variação entre 0,23\% (estação 6) e 7,56\% (estação 7).

No geral, os teores de $\mathrm{CaCO}_{3}$ foram mais elevados nas estações do setor sul do sistema estuarino-lagunar de Cananeia-Iguape. Berbel (2008) e Coelho (2011) sugerem que esta diferença entre os setores norte e sul, ocorra devido a uma diminuição da influência marinha na região em que predomina a água doce advinda do canal do Valo Grande.

\subsubsection{Granulometria}

A granulometria no sistema estuarino-lagunar de Cananeia-Iguape (SP) é relatada por diversos autores com predominância da fração areia (TESSLER, 
FURTADO, 1983; BARCELOS, 2005; BERBEL, 2008; COELHO, 2011). Tessler (1983) atribui esta predominância às variações do nível do mar ocorridas durante a formação do sistema. As frações mais finas (silte e argila) no setor norte do sistema, são atribuídos por Freitas et al. (2006) pelos finos carreados em suspensão através do canal do Valo Grande, que contribuíram para o crescimento da llha Comprida no sentido Nordeste (GUEDES, 2009) e contribuem para o assoreamento do canal principal do sistema estuarino.

Em agosto de 2014 (Fig. 27) nos sedimentos houve predominância da fração areia em todas as amostras analisadas. No rio Ribeira de Iguape as estações R1 e R2 apresentaram uma porcentagem maior de argila, que pode ser explicada pela possível diminuição da velocidade do corpo hídrico, causada pelo padrão meandrante do rio, que possibilita a deposição de materiais finos; no diagrama de Shepard (Fig. 28) as estações R1 e R2 são classificadas como areia argilosa, já as estações R3, R4 e R5 são classificadas como areia ou arenito. Nas estações estuarinas 2, 3 e 7 são consideradas areia argilosa pelo diagrama de Shepard, já as estações 1,5,6 e 11 são consideradas areia ou arenito. Na plataforma as estações MC1, MC3, MC5 e MI5 são consideradas areia argilosa, e as estações Ml1 e MI3 areia ou arenito. 

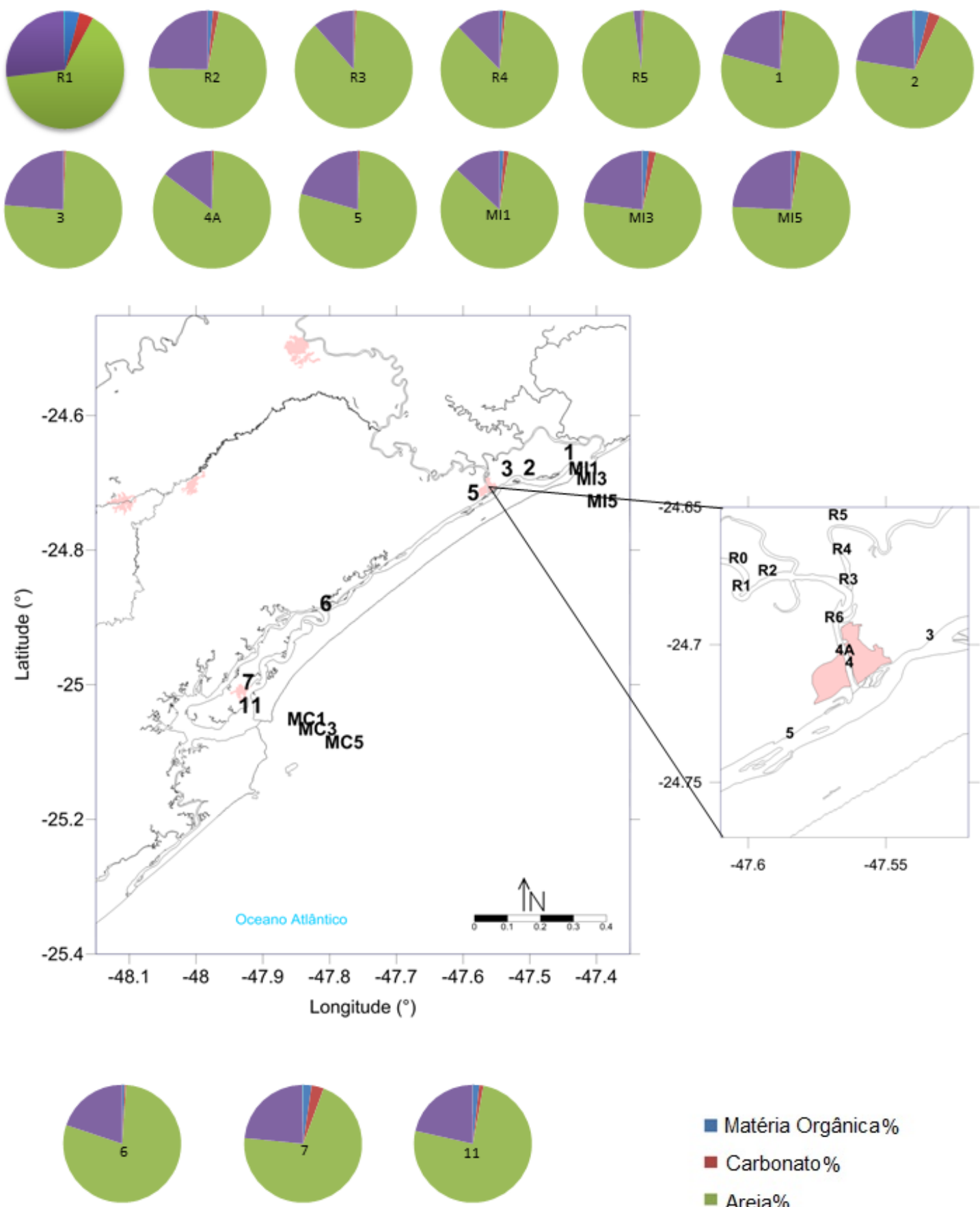

- Matéria Orgânica\%

- Carbonato $\%$

areia\%
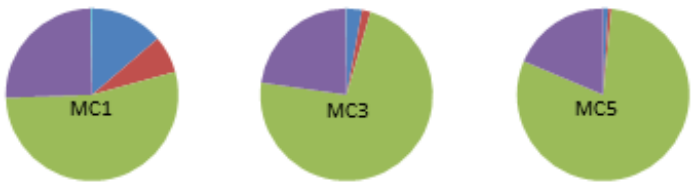

- Silte\%

- Argila $\%$

Figura 27. Distribuição espacial dos dados granulométricos em sedimentos do rio Ribeira de Iguape, sistema estuarino-lagunar de Cananeia-Iguape, Barra de Icapara e Barra de Cananeia (SP). Agosto de 2014. 


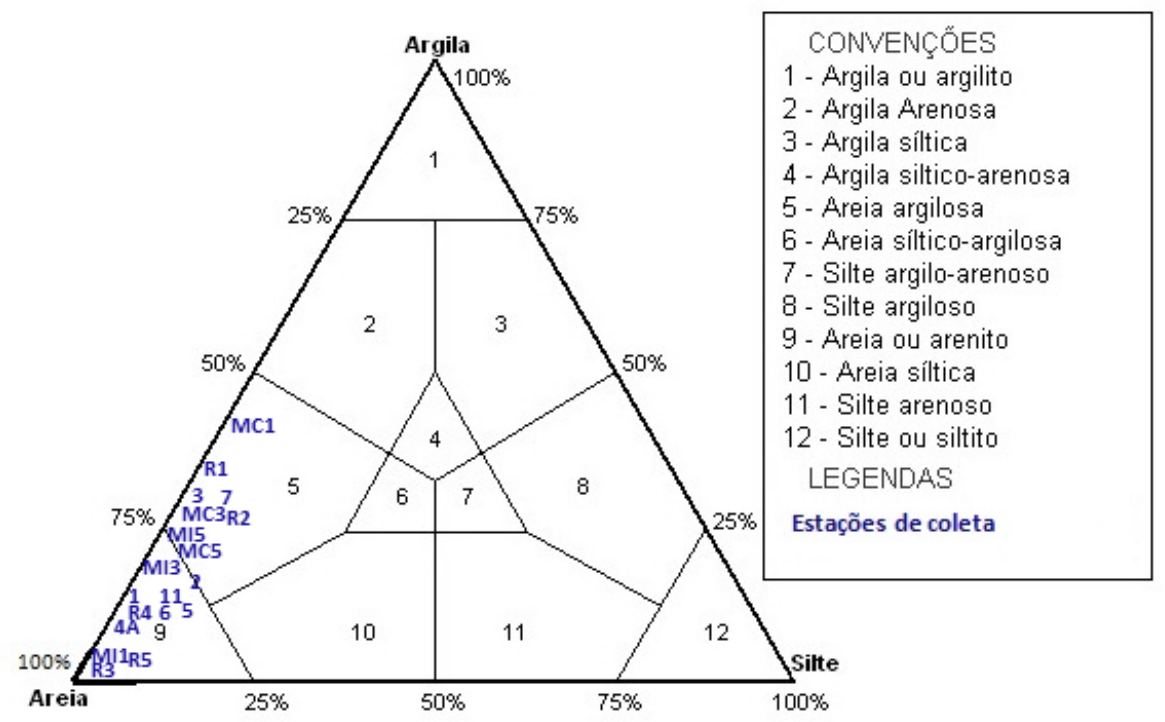

Figura 28. Diagrama de Shepard com dados granulométricos em sedimentos do rio Ribeira de Iguape, sistema estuarino-lagunar de Cananeia-Iguape, Barra de Icapara e Barra de Cananeia (SP). Agosto de 2014.

Na figura 29, observam-se os dados da campanha de maio de 2015. No rio, a estação Vale com apenas $2,0 \%$ de areia é considerada argilosa de acordo com o diagrama de Shepard (Fig. 30), nas demais estações do rio há predominância da fração areia, é importante ressaltar que na estação Registro há a maior presença de areia dentre as amostras do rio, nas estações de R0 a R6 há a presença de maiores teores de silte e argila, sendo as amostras R0, R1 e R4 classificadas como areia argilosa, já as amostras das estações R2, R3, R5 e R6 são classificadas como areia ou arenito, porém estão praticamente no limite entre a areia argilosa e areia, isto nos indica a presença de material fino sendo transportada da drenagem para o sistema estuarino. No corpo estuarino, entre as estações 1 e 11, destaca-se a estação 7 como areia argilosa, as demais foram classificadas como areia ou arenito. 

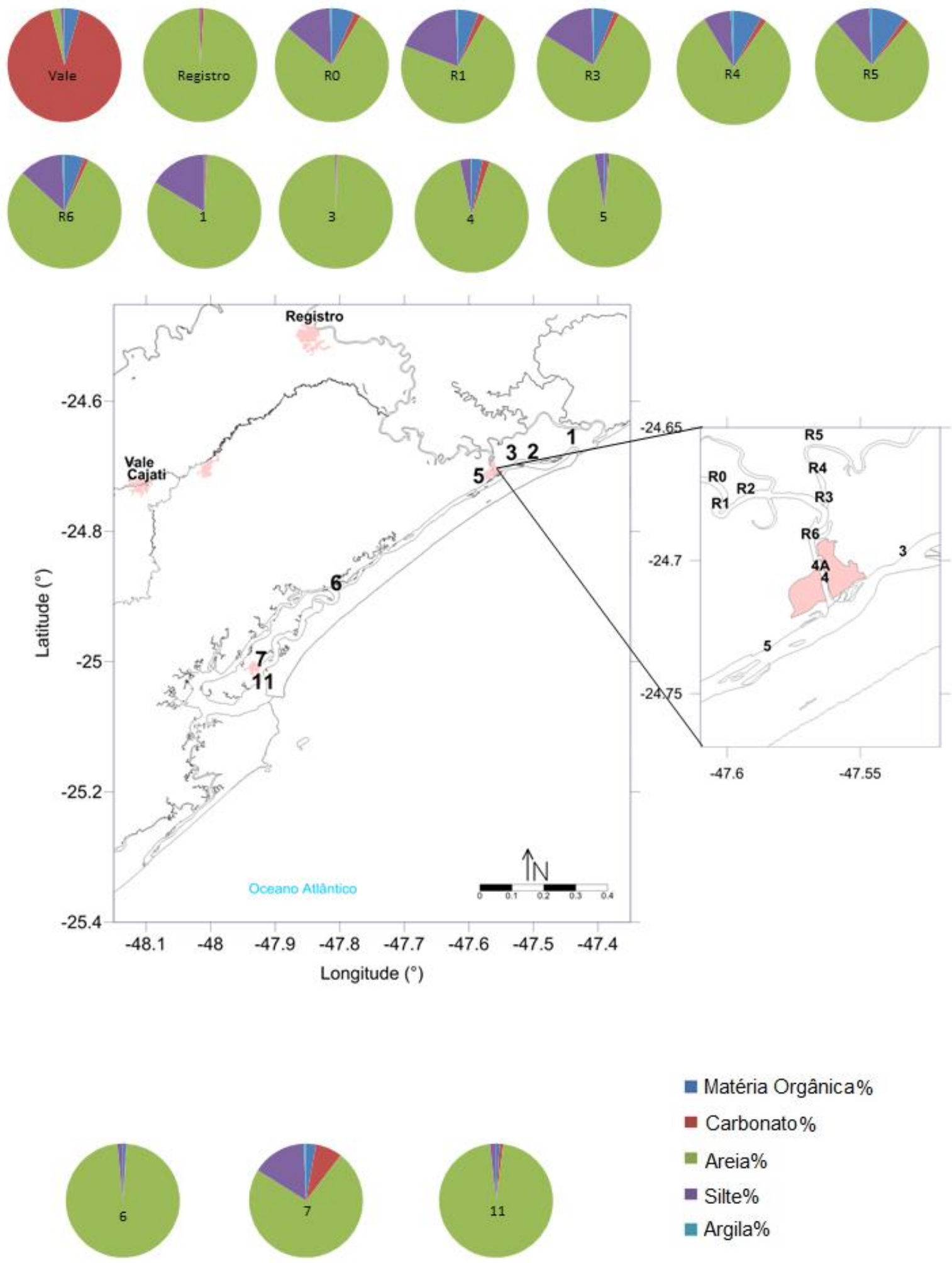

Figura 29. Distribuição espacial dos dados granulométricos em sedimentos do rio Ribeira de Iguape, rio Guaraú e sistema estuarino-lagunar de Cananeia-Iguape (SP). Maio de 2015. 


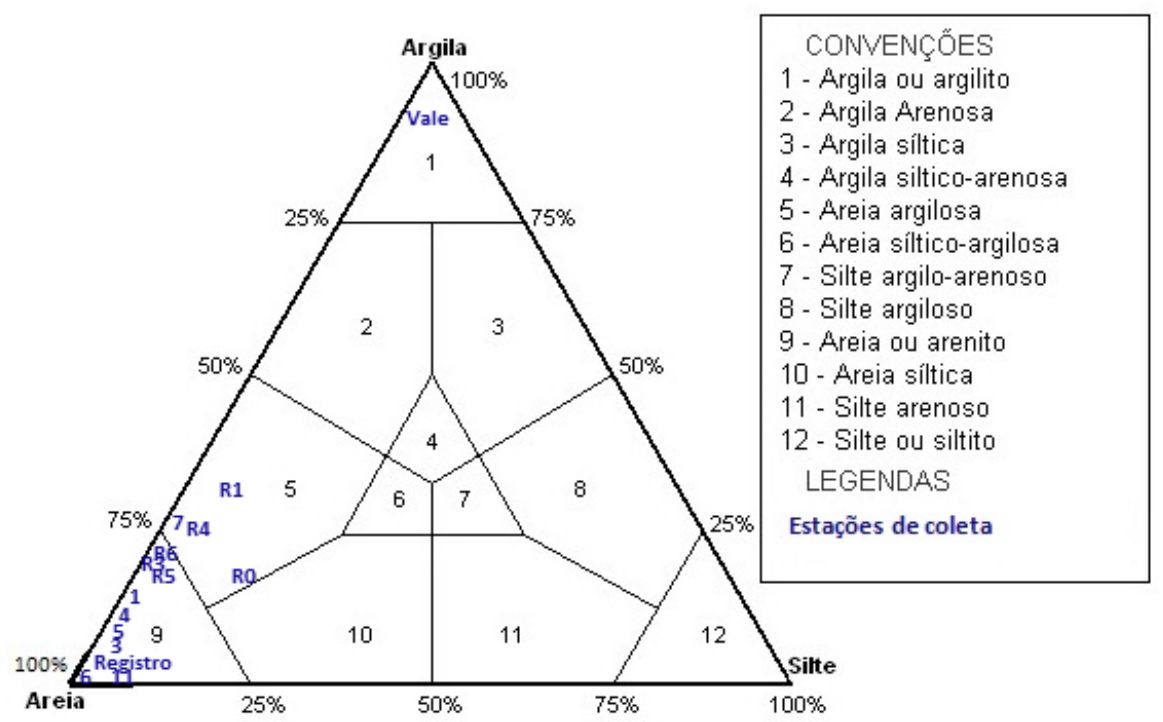

Figura 30. Diagrama de Shepard com dados granulométricos em sedimentos do rio Ribeira de Iguape, Rio Guaraú e sistema estuarino-lagunar de Cananeia-Iguape (SP). Maio de 2015.

Portanto, no inverno de 2014, os teores de $\mathrm{MO}$ e carbonato biodetríticos foram mais elevados que em maio de 2015, sem considerar a estação Vale, pois esta representa o passivo ambiental anterior ao tratamento e retorno ao ambiente, à estes teores mais elevados estão associadas amostras com a presença de fração fina e consideradas, de acordo com o diagrama de Shepard, areia argilosa. As amostras arenosas obtiveram os menores valores de $\mathrm{MO}$ e carbonato biodetríticos. Esta relação entre a presença de finos, MO e carbonato biodetríticos esteve presente também nas amostras de maio de 2015. 
Tabela 7. Quadro sinóptico dos dados de sedimentos em amostras do rio Rio Ribeira de Iguape, rio Guaraú, sistema estuarino-lagunar de Cananeia-Iguape, Barra de Icapara e Barra de Cananeia (SP).

\begin{tabular}{|c|c|c|c|c|c|c|}
\hline Campanha & & MO \% & $\mathrm{Ca} \%$ & Areia \% & Silte\% & Argila $\%$ \\
\hline \multirow{5}{*}{ 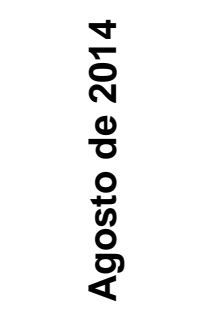 } & $\begin{array}{l}\text { Média } \\
\text { Desvio }\end{array}$ & 2,08 & 1,71 & 79,79 & 20,06 & 0,11 \\
\hline & Padrão & $\pm 3,17$ & $\pm 1,70$ & $\pm 12,10$ & $\pm 5,97$ & $\pm 0,20$ \\
\hline & Mediana & 1,20 & 1,20 & 80,77 & 22,24 & 0,26 \\
\hline & Mínimo & 0,13 & 0,40 & 55,49 & 2,17 & $<\mathrm{LD}$ \\
\hline & Máximo & 14,20 & 7,20 & 97,77 & 26,08 & 0,76 \\
\hline \multirow{5}{*}{ 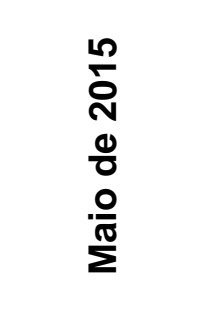 } & $\begin{array}{l}\text { Média } \\
\text { Desvio }\end{array}$ & 3,57 & 7,31 & 78,84 & 7,84 & 0,33 \\
\hline & Padrão & $\pm 3,03$ & $\pm 22,15$ & $\pm 23,49$ & $\pm 6,629$ & $\pm 0,32$ \\
\hline & Mediana & 2,93 & 1,55 & 81,27 & 7,75 & 0,16 \\
\hline & Mínimo & 0,07 & 0,23 & 2,75 & 0,33 & $<\mathrm{LD}$ \\
\hline & Máximo & 9,40 & 87,15 & 98,90 & 17,11 & 0,85 \\
\hline
\end{tabular}

\subsubsection{Extração Sequencial do Fósforo no Sedimento (SEDEX) em Amostras de Superfície do Rio Ribeira de Iguape, Rio Guaraú, Complexo Estuarino-Lagunar de Cananeia-lguape, Barra de Icapara e Barra de Cananeia (SP)}

\subsubsection{Fósforo Biodisponível (P-bio)}

O fósforo biodisponível no sedimento, em agosto de 2014 (Fig. 31) apresentou valores <LD, nas estações R5 e 5 . O valor máximo encontrado foi de 2,54 $\mu \mathrm{mol} \mathrm{g}^{-1}$ na estação $\mathrm{MC1}$. Esse sedimento é composto pela fração areia argilosa, outro fator que pode contribuir também é a atividade biológica mostrada pelos valores de clorofila-a $\left(6,94 \mathrm{mg} \mathrm{m}^{-3}\right)$ e de POP $\left(10,69 \mu \mathrm{mol} \mathrm{L}^{-1}\right)$. Na plataforma continental o P-bio variou entre $0,11 \mu \mathrm{mol} \mathrm{g} \mathrm{g}^{-1}$ e $0,25 \mu \mathrm{mol} \mathrm{g}{ }^{-1}$. O P-bio esteve entre $0,12 \%$ e $18,94 \%$ do Fósforo Total no sedimento (P-T). Considerando o complexo estuarino como um sistema contíguo, observa-se que o P-bio esteve menos elevado nas estações do rio Ribeira de Iguape, e as concentrações se elevaram na estação do canal do Valo Grande (estação 4A) e nas estações do setor norte (1-5) sendo que houve um aumento de três vezes da estação 3 para a 2, variando de $0,17 \mu \mathrm{mol} \mathrm{g} \mathrm{g}^{-1}$ a $0,67 \mu \mathrm{mol} \mathrm{g}^{-1}$ respectivamente. 
Em maio de 2015 (Fig. 31), o P-bio nos sedimentos de superfície variou de <LD na estação Registro a $41,24 \mu \mathrm{mol} \mathrm{g}^{-1}$ na estação Vale, esta última estação possui material contendo fosfogesso proveniente da mineração e produção de ácido fosfórico, portanto é natural que haja uma alta concentração de fósforo fracamente ligado. A fração de P-bio correspondeu de 0,59\% a $27,36 \%$ do fósforo total sedimentar. Nas estações do rio de R0 a R3 o P-bio esteve presente em baixos níveis, no entanto nas estações de R4 a 4A estes valores aumentam (de $0,17 \mu \mathrm{mol} \mathrm{g}{ }^{-1}$ em média, entre as estações R0 e R3, para $0,79 \mu \mathrm{mol} \mathrm{g}{ }^{-1} \mathrm{em}$ média, entre as estações R4 e $4 \mathrm{~A}$ ). Entre as estações 3 e 4, ocorreu novo aumento, provavelmente devido a foz do rio Ribeira de Iguape no sistema estuarino-lagunar. Na estação 5 se verificou uma diminuição de P-bio no sedimento, no entanto como pode ser observado na figura 24d, houve um incremento de fósforo na fração particulada que apresenta 67,62 $\mu \mathrm{mol} \mathrm{g}^{-1}$ de PIP. Na transição entre as estações 5 e 6 ocorreu um aumento de $0,28 \mu \mathrm{mol} \mathrm{g}{ }^{-1}$ para $1,03 \mu \mathrm{mol} \mathrm{g}^{-1}$, provavelmente parte do fósforo foi floculado $\mathrm{e}$ passou a apresentar-se na forma sedimentar. $\mathrm{Na}$ estação 7 houve novo aumento nas concentrações de $\mathrm{P}$-bio, devido à modificação da granulometria da amostra que passou a apresentar material fino (silte e argila) (Fig. 30). No caso da estação 11 a influência da água salina pode ter contribuído à diminuição na concentração de P-bio. 


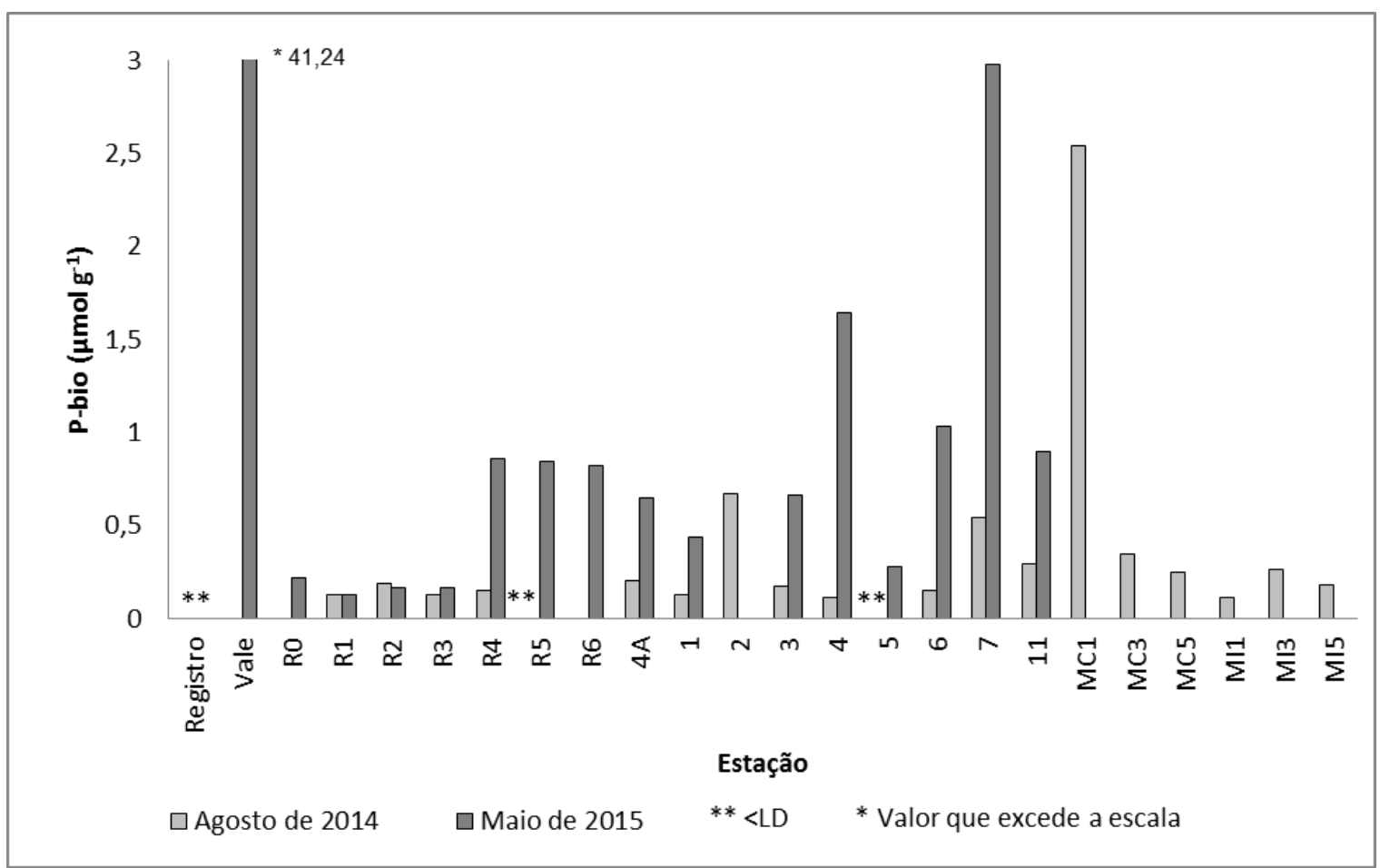

Figura 31. Distribuição espacial das concentrações de P-bio $\left(\mu \mathrm{mol} \mathrm{g}{ }^{-1}\right)$ de amostras sedimentares do Rio Guaraú, Rio Ribeira de Iguape e complexo estuarino-lagunar de Cananeia-Iguape (SP), em Agosto de 2014 e Maio de 2015.

No complexo estuarino-lagunar de Cananeia-lguape Berbel (2008), encontrou valores que no inverno estiveram entre $0,15 \mu \mathrm{mol} \mathrm{g}^{-1}$ e $1,58 \mu \mathrm{mol} \mathrm{g}^{-1}$, estas concentrações de P-bio compuseram de $7 \%$ a $31 \%$ do fósforo total no sedimento. No trabalho atual, os teores de P-bio foram mais elevados, porém compõem uma parcela menor do P-T.

Berbel et al. (2015) apresentam concentrações de P-bio no sedimento entre $0,24 \mu \mathrm{mol} \mathrm{g}{ }^{-1}$ e 9,36 $\mu \mathrm{mol} \mathrm{g}{ }^{-1}$, com variação no percentual entre $5,1 \%$ e $27,1 \%$ em relação ao P-T em relação ao P-T no estuário de Santos-São Vicente (Brasil-SP).

Em sedimentos superficiais do estuário do rio Changjiang (China), Meng et al. (2014) encontraram valores entre $0,30 \mu \mathrm{mol} \mathrm{g}^{-1}$ e $0,95 \mu \mathrm{mol} \mathrm{g}^{-1}$. Esses valores perfizeram $1,4 \%$ e $5,3 \%$ do $\mathrm{P}$-T, com uma média de $2,5 \%$. Os referidos autores atribuíram o valor mais elevado, à entrada de fosfato no sistema estuarino através da bacia de drenagem. Na campanha de maio de 2015 no sistema estuarino-lagunar de Cananeia-Iguape, houve comportamento similar na foz do rio Ribeira de Iguape para o interior do sistema estuarino (entre as estações R4 e 4) com o aumento nas concentrações de P-bio. 
Observando-se as duas campanhas, inverno de 2014 e outono de 2015, houve uma maior concentração de P-bio em maio de 2015, que pode ter ocorrido provavelmente devido ao período sazonal, pois no outono ocorre o início processo de remineralização da matéria orgânica, formada no período de verão.

\subsubsection{Fósforo Ligado ao Ferro (P-Fe)}

A fase do P-Fe como indicado por diversos autores (RUTTENBERG, 1992; BIANCH, 2007; BERBEL, 2008; BERBEL et al., 2015) compõe geralmente mais de $20 \%$ do fósforo total sedimentar (P-T) e está intimamente ligado à atividades antropogênicas (HOWARTH et al., 1995; ZHUANG et al., 2014).

As concentrações de P-Fe no sedimento (Fig. 32), em agosto de 2014, apresentaram variação entre $\angle L D$ na estação $M C 5$ e 32,85 $\mu \mathrm{mol} \mathrm{g}^{-1}$ na estação R2. Esta fase compôs de 20,54 \% a 95,48 \% do fósforo total sedimentar (P-T). Nas margens do rio Ribeira de Iguape há processo erosivo atuante, principalmente em locais com a presença de pasto degradado, que carreia solo e matéria orgânica proveniente dos dejetos de animais para o corpo hídrico, como é o caso das proximidades do ponto de coleta R2.

Nos pontos de coleta do rio Ribeira de Iguape, o P-Fe apresentou comportamento levemente inverso do registrado no P-bio, nas estações $R 1, R 2$ e R3, ocorreram os valores mais elevados (entre $14,53 \mu \mathrm{mol} \mathrm{g}^{-1}$ e $32,85 \mu \mathrm{mol} \mathrm{g}$ $\left.{ }^{1}\right)$ neste setor, enquanto que nas estações $R 4$, R5 e $4 A$, ocorreu uma tendência de diminuição dos valores, entre $10,23 \mu \mathrm{mol} \mathrm{g}^{-1}$ a $1,71 \mu \mathrm{mol} \mathrm{g}{ }^{-1}$.

Ao adentrar no complexo estuarino-lagunar propriamente dito, os valores de P-Fe diminuem, de 9,41 $\mu \mathrm{mol} \mathrm{g}^{-1}$ na estação 4 (localizada junto ao canal do Valo Grande) para em média $3,80 \mu \mathrm{mol} \mathrm{g}{ }^{-1}$ nas estações 5 e 6 . No setor norte, em direção à Barra de Icapara, ocorre o aumento na concentração de P-Fe na estação $2\left(17,35 \mu \mathrm{mol} \mathrm{g}^{-1}\right)$, esta elevação ocorre provavelmente devido à presença de grãos finos no sedimento e devido à da zona de máxima turbidez, que indica a ocorrência de processos de sedimentação. No setor sul, há uma menor concentração de P-Fe na estação $7\left(4,18 \mu \mathrm{mol} \mathrm{g}{ }^{-1}\right)$, porém na estação 11 há um aumento para $10,64 \mu \mathrm{mol} \mathrm{g}{ }^{-1}$, que pode ser devido aos processos erosivos presentes nesta porção do sistema estuarino, próximo à 
Ilha Comprida, devido à forte entrada da maré neste setor do sistema. Na Barra de Cananeia, houve uma tendência de diminuição desta forma de $P$ sedimentar, os valores neste setor, estiveram entre $<L D$ e $5,31 \mu \mathrm{mol} \mathrm{g}^{-1}$ na estação $M C 1$, esse valor um pouco mais elevado pode ser explicado pela maior presença de material fino, que possui maior afinidade com o ferro. Nas estações da Barra de Icapara, houve uma variação de $0,70 \mu \mathrm{mol} \mathrm{g}{ }^{-1}$ a 7,61 $\mu \mathrm{mol} \mathrm{g}{ }^{-1}$.

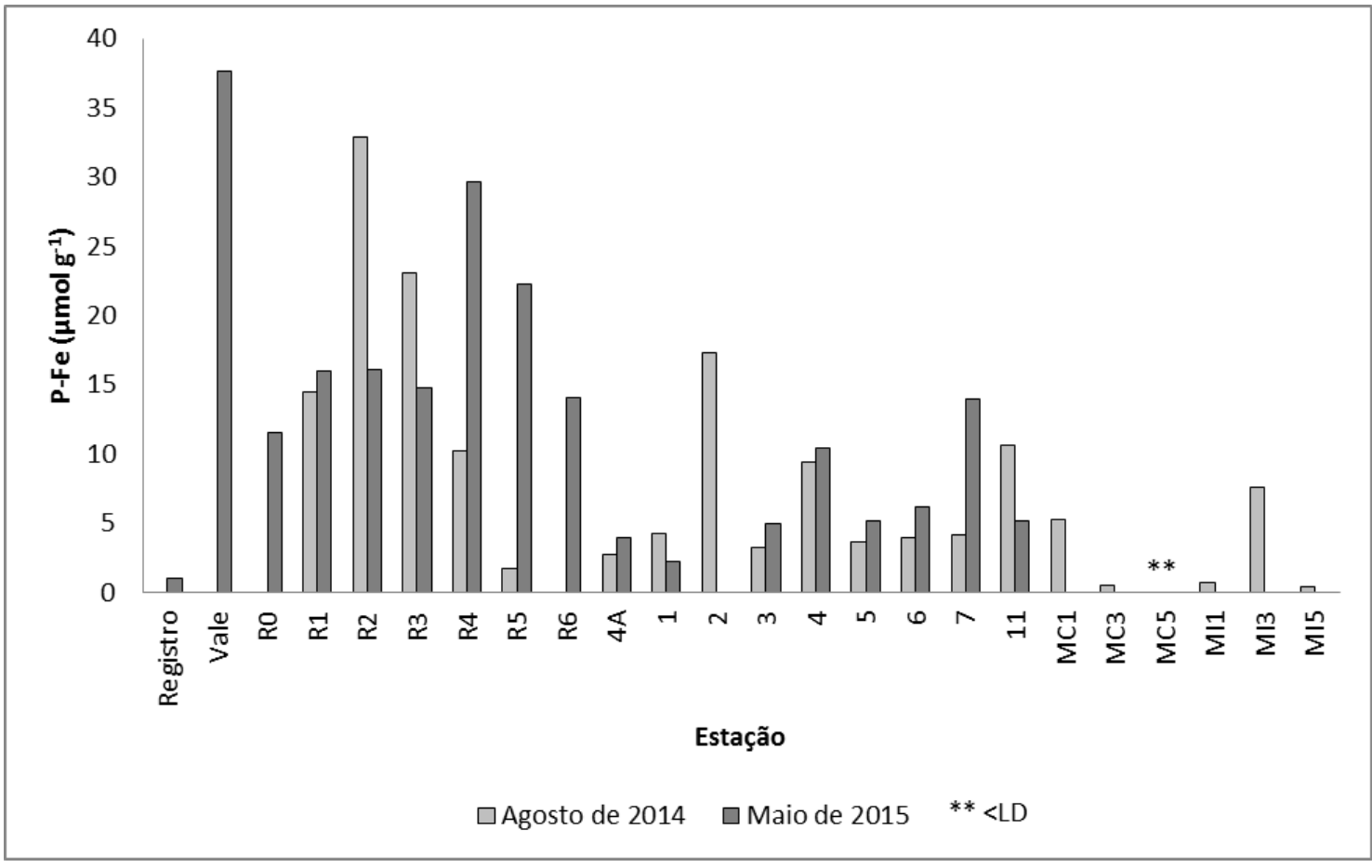

Figura 32. Distribuição espacial das concentrações de $\mathrm{P}-\mathrm{Fe}\left(\mu \mathrm{mol} \mathrm{g}^{-1}\right)$ de amostras sedimentares do Rio Guaraú, Rio Ribeira de Iguape e complexo estuarino-lagunar de Cananeia-Iguape (SP), em Agosto de 2014 e Maio de 2015.

$\mathrm{Na}$ campanha de maio de 2015, as concentrações de fósforo ligado ao ferro, apresentaram variação entre $1,00 \mu \mathrm{mol} \mathrm{g}{ }^{-1}$ na estação Registro e 37,68 $\mu \mathrm{mol} \mathrm{g}^{-1}$ na estação Vale, os valores foram ligeiramente mais elevados do que os encontrados em agosto de 2014. No setor do rio, na figura 32 pode-se observar que à jusante da estação Registro ocorre um aumento geral nas concentrações de $\mathrm{P}-\mathrm{Fe}$, isso pode ter ocorrido devido à possível inserção de fósforo advindo do tributário rio Jacupiranga, que recebe material da mineração na cidade de Cajati. Neste ano foi possível verificar que o rio agiu como fonte de P-Fe para o sistema estuarino, devido à alta concentração encontrada na 
estação $4\left(10,42 \mu \mathrm{mol} \mathrm{g}{ }^{-1}\right)$, valor mais próximo aos observados no rio. Em direção ao setor sul houve uma diminuição de teores entre as estações 5 e 6 (para $6,00 \mu \mathrm{mol} \mathrm{g}{ }^{-1}$ em média). Na estação 7 houve aumento no teor de P-Fe para $13,93 \mu \mathrm{mol} \mathrm{g}{ }^{-1}$, esse padrão de distribuição geoquímica foi encontrado também em agosto de 2014. Na estação 11, ocorreu uma diminuição na concentração, $5,13 \mu \mathrm{mol} \mathrm{g}{ }^{-1}$.

Berbel (2008), nas proximidades da llha de Cananeia no inverno, encontrou valores de P-Fe que variaram entre $0,48 \mu \mathrm{mol} \mathrm{g}^{-1}$ e 3,40 $\mu \mathrm{mol} \mathrm{g}{ }^{-1}$, a autora atribuiu à variação dos teores da granulometria dos sedimentos. No trabalho atual, mesmo para o setor de sul tenha apresentado valores mais baixos de P-Fe em relação ao setor norte, foram encontrados valores mais altos que a autora supra citada, podendo indicar um aumento na ação antrópica entre 2006 e 2014 no complexo estuarino-lagunar de CananeiaIguape.

No estuário do rio Changjiang (China) Meng et al. (2014), encontraram valores de P-Fe entre $0,05 \mu \mathrm{mol} \mathrm{g}{ }^{-1}$ e $0,95 \mu \mathrm{mol} \mathrm{g}{ }^{-1}$, perfazendo de $0,3 \%$ a 3,7 $\%$ do P-T. Os autores atribuíram estes valores baixos às condições ambientais não favoráveis à coprecipitação de óxidos/hidróxidos de Fe. No estuário de Santos-São Vicente, Berbel et al. (2015) apresentaram concentrações de P-Fe que variaram entre $1,09 \mu \mathrm{mol} \mathrm{g}^{-1}$ e 37,68 $\mu \mathrm{mol} \mathrm{g}^{-1}$, em percentagem de $21 \%$ a $53 \%$, nas estações de que apresentaram os maiores teores (acima de $40 \%$ ) representam as áreas com maior influência antrópica do distrito industrial de Cubatão.

Neste trabalho, os valores encontrados foram mais elevados em todos os pontos amostrados, do que os observados por Meng et al. (2014) indicando que no complexo estuarino-lagunar de Cananeia-Iguape (SP) as condições para a formação de P-Fe nos sedimentos são mais favoráveis. Porém, os valores dos dois períodos sazonais (inverno de 2014 e outono de 2015) corroboraram com as indicações de Berbel et al. (2015), nos sedimentos de superfície todas as estações apresentaram teores mais elevados do que $40 \%$ em relação ao P-T, exceto nas estações de agosto de 2014: R2, 6 e MC5, nas quais a forma predominante foi a de P-org; e na estação Vale de maio de 2015 , onde predominou a forma P-bio. 
No complexo estuarino-lagunar de Cananeia-Iguape (SP) a granulometria não foi a principal determinante para a concentração do $\mathrm{P}-\mathrm{Fe}$ nos sedimentos de superfície. Como pode ser observado, na tabela 9 estão representados os parâmetros que obtiveram correlação significativa positiva com o fósforo ligado ao ferro em agosto de 2014: silicato $(r=0,522), P-F A P(r=$ 0,512), P-org $(r=0,685)$ e P-T $(r=0,813)$.

$\mathrm{Na}$ tabela 10, observam-se as correlações do P-Fe obtidas através dos dados de maio de 2015. O P-Fe obteve correlação positiva significativa com o P-FAP $(r=0,815)$, o P-org $(r=0,595)$ e o P-T $(r=0,980)$. No inverno não ocorreu correlação significativa entre o P-Fe e o P-org, porém no outono de 2015 houve correlação entre os dois parâmetros, isso pode indicar que no outono o processo de remineralização da matéria orgânica, também pode estar auxiliando na coprecipitação de óxidos/hidróxidos de Fe e a adsorção do P. As correlações obtidas nas duas campanhas constituem mais um indicativo de que existe um processo antrópico atuante na inserção de fósforo na bacia de drenagem que deságua no sistema estuarino-lagunar. Berbel et al. (2015) no estuário de Santos-São Vicente, também obtiveram correlação significativa entre P-Fe e P-FAP; e atribuíram esse fato à inserção de PID no sistema hídrico advindo do distrito industrial de Cubatão.

\subsubsection{Fósforo Ligado à Apatita Autigênica (P-CFAP)}

A forma P-CFAP no sedimento é composta pela associação do $\mathrm{P}$ a carbonato e fluorapatita autigênica, apatita biogênica e carbonatos (MENG et al., 2014). Sua formação ocorre em condições aeróbicas, com pH entre 6,0 e 9,0 e com baixas concentrações de cálcio $\left(1,0.10^{-3}\right)$ (SPIVAKOV et al., 1999).

Em agosto de 2014 os teores de P-CFAP (Fig. 33) encontrados no trabalho atual, estiveram entre $0,28 \mu \mathrm{mol} \mathrm{g}{ }^{-1}$ na estação 5 e 1,21 $\mu \mathrm{mol} \mathrm{g}^{-1}$ na estação $\mathrm{MC1}$, a qual apresentou classificação granulométrica areia argilosa. A porcentagem de P-CFAP em relação ao P-T variou de 0,27 \% na estação R2 a 24,42 \% na estação MI5, em média a concentração de P-CFAP em relação ao fósforo total foi de 7,89 \%. Na plataforma as maiores concentrações de PCFAP, estão associadas às estações que contam com a presença de material fino. 
Na campanha de maio de 2015 (Fig. 33), o P-CFAP no geral foi mais elevado do que em agosto de 2014. A menor concentração foi encontrada na estação Registro (de $0,21 \mu \mathrm{mol} \mathrm{g}{ }^{-1}$ ), já o maior valor foi encontrado foi de 34,21 $\mu \mathrm{mol} \mathrm{g}^{-1}$ na estação Vale, lembrando que esta amostra provém da exploração do fosfogesso, resíduo da mineração e da produção de ácido fosfórico. A porcentagem deste parâmetro em relação ao P-T esteve entre 2,86 \% na estação R1 e 22,69 \% na estação Vale, em média 7,16 \%. Os maiores valores estiveram associados às estações do rio Ribeira de lguape (R0-R6), houve um aumento expressivo na concentração de P-CFAP da estação R2 para a R3, de $0,86 \mu \mathrm{mol} \mathrm{g}{ }^{-1}$ para $4,10 \mu \mathrm{mol} \mathrm{g}^{-1}$. Ao adentrar no canal do Valo Grande (estação $4 \mathrm{~A}$ ) há uma diminuição no valor para $0,23 \mu \mathrm{mol} \mathrm{g}^{-1}$. No sentido do setor sul há (entre as estações 3-11) os valores de P-CFAP encontrados estiveram em torno de $0,30 \mu \mathrm{mol} \mathrm{g}^{-1}$, exceto na estação 7 que há um aumento na concentração para $1,02 \mu \mathrm{mol} \mathrm{g}{ }^{-1}$, devido provavelmente a presença de areia argilosa neste ponto de coleta.

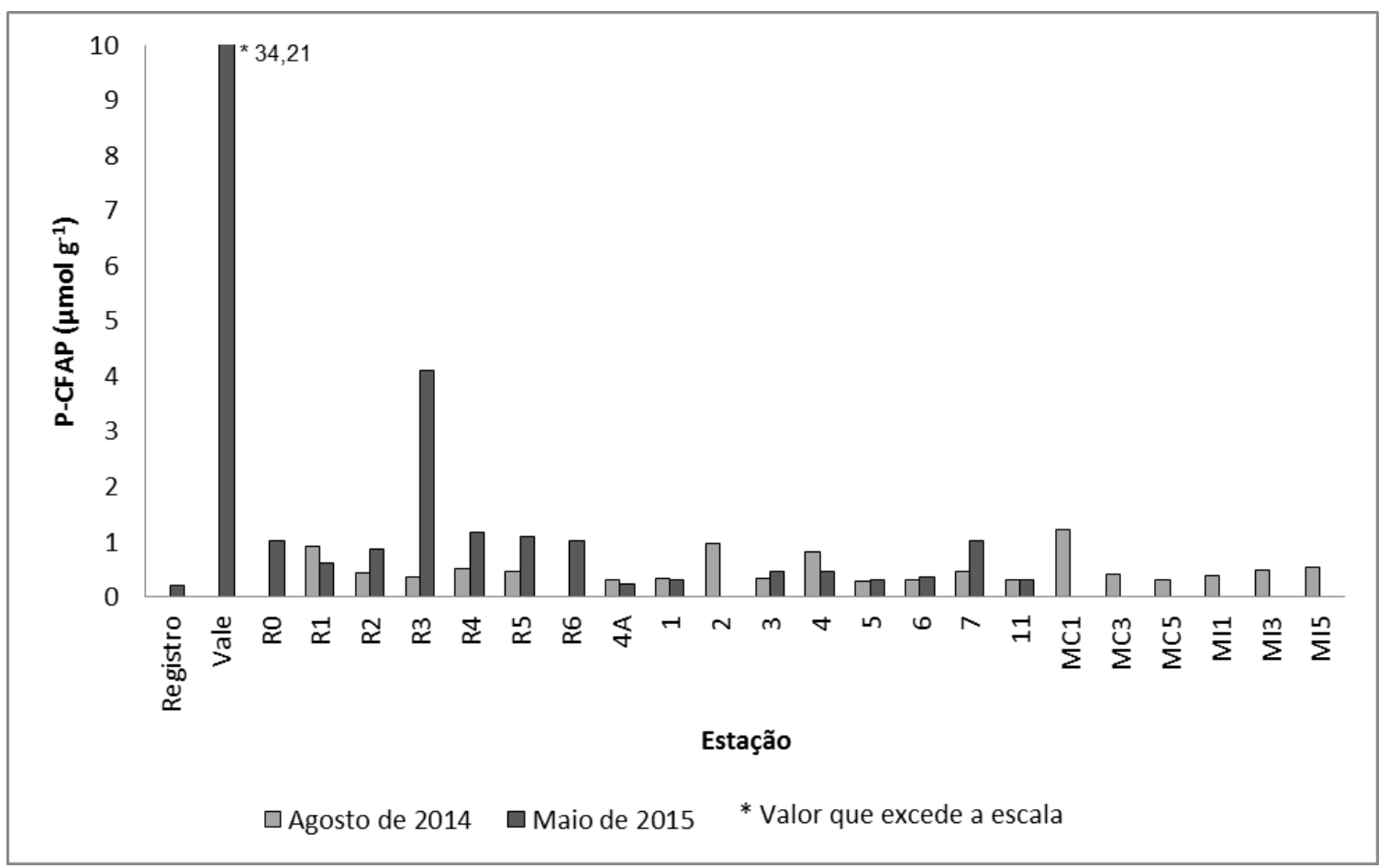

Figura 33. Distribuição espacial das concentrações de P-CFAP $\left(\mu \mathrm{mol} \mathrm{g}{ }^{-1}\right)$ de amostras sedimentares do Rio Guaraú, Rio Ribeira de Iguape e complexo estuarino-lagunar de Cananeia-Iguape (SP), em Agosto de 2014 e Maio de 2015. 
Meng et al. (2014) encontraram no estuário do rio Changjiang (China), teores de P-CFAP que variaram de $0,54 \mu \mathrm{mol} \mathrm{g}^{-1}$ a $1,50 \mu \mathrm{mol} \mathrm{g}{ }^{-1}$, em relação ao P-T essa fração representou de 2,5\% a 9,6\%, em média 5,5\%. Os valores encontrados neste trabalho estão de acordo com o autor supracitado, exceto pela estação Vale (outono de 2015). Berbel et al. (2015) apresentaram valores de P-CFAP entre $0,36 \mu \mathrm{mol} \mathrm{g}^{-1}$ e $10,64 \mu \mathrm{mol} \mathrm{g}^{-1}$, perfazendo de $4 \%$ a $17 \%$ do fósforo total sedimentar.

Meng et al. (2014) e Berbel et al. (2015), apontaram esta fase como a que possui menor concentração em relação ao P-T. Neste trabalho o P-CFAP foi encontrado em média de $7,51 \%$, entre as duas campanhas sazonais (inverno de 2014 e outono de 2015), corroborando o apontado pelos autores supracitados.

\subsubsection{Fósforo Ligado à Fluorapatita (P-FAP)}

O P-FAP corresponde a uma fase não reativa de fósforo sedimentar (RUTTENBERG, 1992). Sua presença está portanto correlacionada a granulometria mais grosseira (areia), diferentemente das outras fases de P o PFAP é composto por minerais primários, como quartzo e feldspato (MENG et al., 2014).

No inverno de 2014 as concentrações de P-FAP (Fig. 34) apresentaram seu menor valor de $0,12 \mu \mathrm{mol} \mathrm{g}^{-1}$ nas estações 11 e MC5, enquanto o maior foi de $2,30 \mu \mathrm{mol} \mathrm{g}^{-1}$ na estação R1. A porcentagem de P-FAP no P-T teve um mínimo de 0,7\% na estação R2, e um máximo de $17 \%$ na estação 4A.

Durante o outono de 2015 os valores de P-FAP (Fig. 34) estiveram entre concentrações <LD, estações 1 e 3, e 1,44 $\mu \mathrm{mol} \mathrm{g}{ }^{-1}$ na estação R1. Este parâmetro representou uma média de $2,8 \%$ do P-T, com máximos de $6,7 \%$ e $6,6 \%$ nas estações $\mathrm{R} 1$ e R3, respectivamente. 


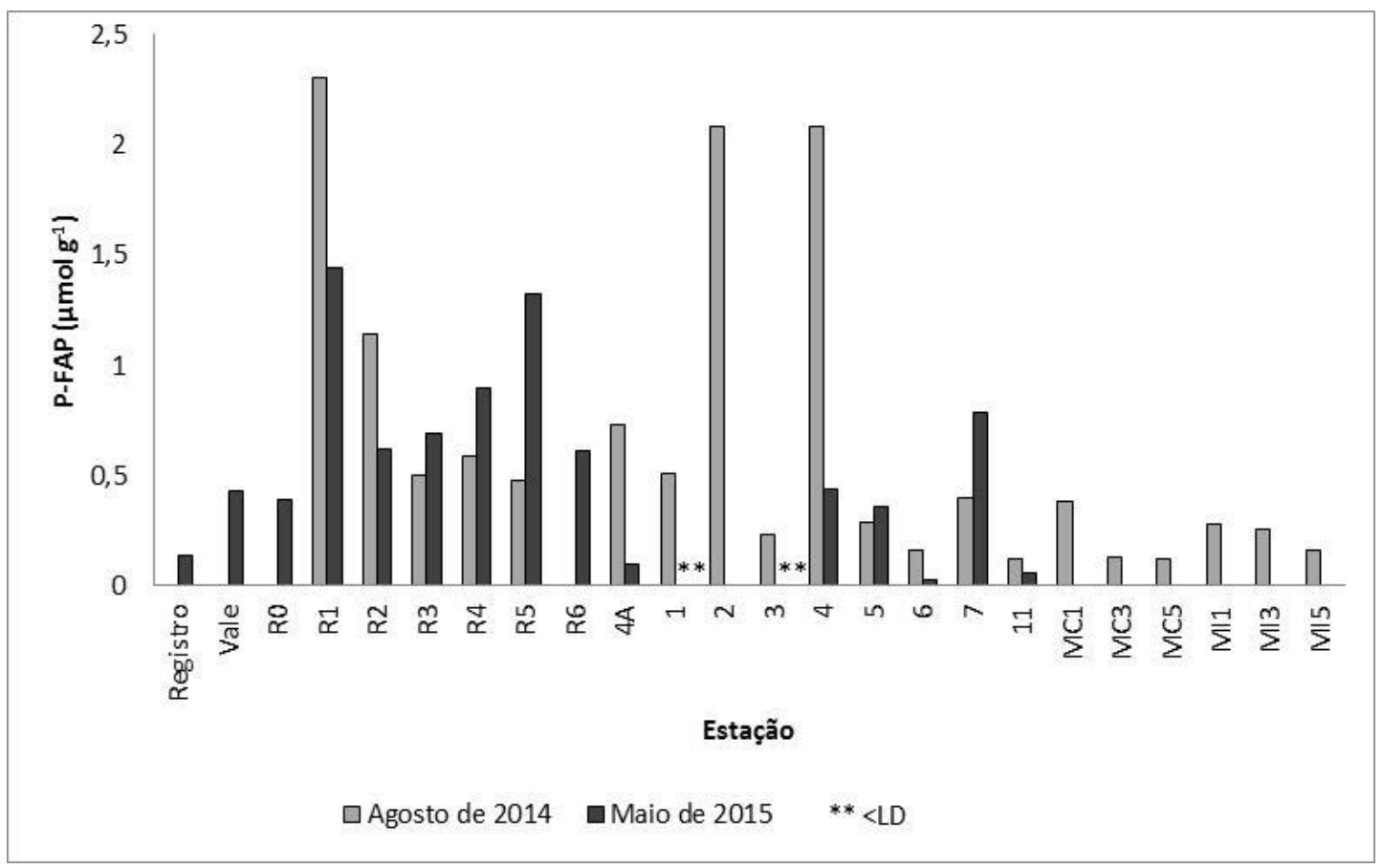

Figura 34. Distribuição espacial das concentrações de P-FAP $\left(\mu \mathrm{mol} \mathrm{g}^{-1}\right)$ de amostras sedimentares do Rio Guaraú, Rio Ribeira de Iguape e complexo estuarino-lagunar de Cananeia-Iguape (SP), em Agosto de 2014 e Maio de 2015.

No geral, entre as duas campanhas realizadas neste trabalho, observouse no setor norte do complexo estuarino-lagunar de Cananeia-Iguape uma maior concentração de P-FAP (Fig. 38) em relação ao setor sul do sistema e da plataforma continental, junto às Barras e Cananeia e Icapara. Este comportamento pode evidenciar uma influência da inserção de material erodido no sistema estuarino, advinda do rio Ribeira de Iguape.

Berbel (2008) encontrou, no setor sul do sistema estuarino, valores (de no mínimo $0,07 \mu \mathrm{mol} \mathrm{g}^{-1}$ a no máximo $1,06 \mu \mathrm{mol} \mathrm{g}^{-1}$ ) mais elevados de P-FAP na presença de sedimentos mais grossos e siltes não trabalhados. Neste trabalho, as estações que apresentaram valores mais altos de P-FAP continham mais de $20 \%$ de silte em sua composição granulométrica.

Meng et al. (2014), encontraram uma variação de P-FAP entre 6,88 $\mu \mathrm{mol} \mathrm{g}{ }^{-1}$ e $13,23 \mu \mathrm{mol} \mathrm{g}{ }^{-1}$, no estuário do rio Changjiang (China), esta fração compôs em média 55,6 \% do fósforo total no sedimento. Os autores indicam o rio Changjiang como a fonte de P-FAP para o sistema estuarino. Berbel et al. (2015) também encontraram, valores mais baixos de P-FAP, com um mínimo de 0,94 e máximo de 7,21, perfazendo de $7 \%$ a $24 \%$ do P-T. Em relação a estes dois trabalhos, no complexo estuarino-lagunar de Cananeia-Iguape os 
valores de P-FAP foram menos elevados, com uma média de 9,77\% entre as duas campanhas realizadas.

\subsubsection{Fósforo Orgânico (P-org)}

Em agosto de 2014 (Fig. 35), os valores de fósforo orgânico no sedimento (P-org) variaram de $0,09 \mu \mathrm{mol} \mathrm{g}{ }^{-1}$, na estação 5 , a 125,29 $\mu \mathrm{mol} \mathrm{g}^{-1}$ na estação R2. Este valor extremamente alto ocorreu provavelmente devido à proximidade do ponto de coleta com áreas de pastagem na margem do rio Ribeira de Iguape. Os demais valores estiveram abaixo de $13,35 \mu \mathrm{mol} \mathrm{g}^{-1}$, com este segundo máximo ocorrendo na estação 6 , estação de coleta que fica localizada próximo ao manguezal, podendo os sedimentos sofrerem influência dos ácidos húmicos que estão presentes no substrato deste bioma. Esse parâmetro correspondeu à $0,4 \%$ do P-T na estação R3, à 78 \% do P-T na estação R2, e à 74 \% na estação 6.

Na campanha de maio de 2015 (Fig. 35) a concentração média de Porg $\left(3,64 \mu \mathrm{mol} \mathrm{g} \mathrm{g}^{-1}\right)$ foi menor que no ano anterior $\left(8,44 \mu \mathrm{mol} \mathrm{g}{ }^{-1}\right)$. O teor teve um mínimo de $0,03 \mu \mathrm{mol} \mathrm{g}^{-1}$ na estação 3 e um máximo de $37,16 \mu \mathrm{mol} \mathrm{g}^{-1}$ na estação Vale. Dentro do sistema, o máximo observado foi de $4,54 \mu \mathrm{mol} \mathrm{g}{ }^{-1}$ na estação 7. Em termos relativos, o P-org variou de $1 \%$ nas estações 3, 6 e 11 a 32 \% na estação Registro. 


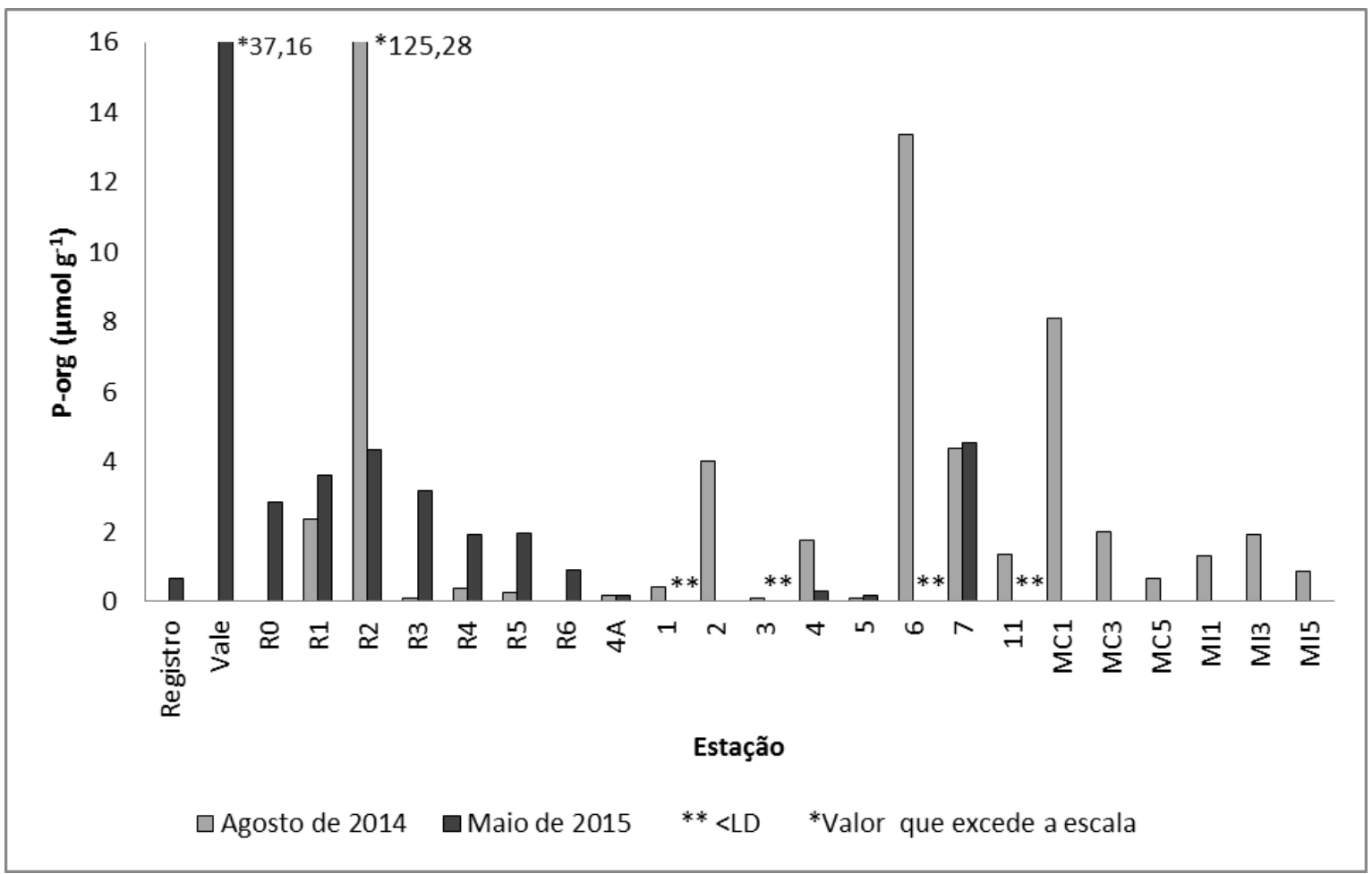

Figura 35. Distribuição espacial das concentrações de P-org $\left(\mu \mathrm{mol} \mathrm{g}{ }^{-1}\right)$ de amostras sedimentares do Rio Guaraú, Rio Ribeira de Iguape e complexo estuarino-lagunar de Cananeia-Iguape (SP), em Agosto de 2014 e Maio de 2015.

Nas estações amostradas tanto em agosto de 2014 quanto em maio de 2015, observou-se que o P-org esteve abaixo do limite de detecção do método (<LD), possuem concentração de P-bio mais elevadas, indicando que possivelmente o P-bio está sendo disponibilizado através da remineralização da matéria orgânica. Essa relação possui coeficiente de correlação significativa positiva com $r=0,982$.

No complexo estuarino-lagunar de Cananeia-Iguape, Berbel (2008) encontrou valores que variaram entre $0,27 \mu \mathrm{mol} \mathrm{g}^{-1}$ a $7,51 \mu \mathrm{mol} \mathrm{g}{ }^{-1}$, associados à granulometria composta por sedimentos finos e à contribuição da alta produtividade primária que ocorre junto ao fundo. Neste trabalho, as estações que apresentaram maiores valores de P-org, também apresentaram teores mais elevados de material particulado orgânico em suspensão (MPOS) e fósforo orgânico particulado em suspensão (POP). Barcelos et al. (2005), em estudo no mesmo sistema estuarino com uma malha amostral mais ampla, obteve no máximo $5,00 \mu \mathrm{mol} \mathrm{g}^{-1}$ de P-org sedimentar. Dentre esses dois estudos citados, este trabalho apresentou valores mais elevados de P-org. 
O estuário do rio Changjiang (China) segundo Meng et al. (2014), esteve com menores variações de P-org, porém elas foram menos elevadas do que as encontradas no complexo estuarino-lagunar de Cananeia-Iguape, com concentração de $1,54 \mu \mathrm{mol} \mathrm{g}{ }^{-1}$ a $4,27 \mu \mathrm{mol} \mathrm{g}^{-1}$, perfazendo no máximo $26,3 \%$ do fósforo total sedimentar.

Ruttenberg (2005) apontou uma média na porcentagem de P-org em relação do P-T em sedimentos marinhos entre $25 \%$ e $30 \%$. Em agosto de 2014 as estações: R2 (78,36 \%), 6 (74,41\%), 7 (43,91\%), MC1 (46,21\%), MC3 (57,89 \%), MC5 (49,24 \%), MI1 (47,12\%) e MI5 (39,17\%), estão acima da média do teor de fósforo orgânico proposto pela autora (op cit); em maio de 2015 somente a estação Registro (31,93\%), apresentou em porcentagem valor maior que $25 \%$.

\subsubsection{Fósforo Total (P-T)}

O fósforo total (P-T) compõem a soma das cinco formas analisadas através da metodologia SEDEX (RUTTENBERG, 1992) e CDB-MAGIC (HUERTA-DIAZ et al., 2005).

O P total em agosto de 2014 (Tab. 8) variou de 1,32 $\mu \mathrm{mol} \mathrm{g}^{-1}$ na estação MC5, a 159,90 $\mu \mathrm{mol} \mathrm{g}^{-1}$ na estação R2, os demais valores estiveram abaixo de 24,13 $\mu \mathrm{mol} \mathrm{g}^{-1}$ encontrado na estação R5. Na coleta de maio de 2015 (Tab. 8), variando entre 2,07 $\mu \mathrm{mol} \mathrm{g}^{-1}$ na estação Registro e 150,72 $\mu \mathrm{mol} \mathrm{g}{ }^{-1}$ na estação Vale, o segundo maior valor foi de $34,46 \mu \mathrm{mol} \mathrm{g}^{-1}$ na estação R4. Assim, os valores foram ligeiramente mais elevados no outono de 2015 em relação ao inverno de 2014 (Fig. 36). 
Tabela 8. Estatística descritiva dos dados da extração de fósforo sequencial no sedimento (SEDEX) nas frações P-bio, P-Fe, PCFAP, P-FAP,P-org e P-T em amostras do Estuário de Cananeia-Iguape e Rio Riberia de Iguape (SP) da campanha de agosto de $2014(n=20)$ e maio de $2015(n=17)$.

\begin{tabular}{|c|c|c|c|c|c|c|c|}
\hline Campanha & Estatística & $\begin{array}{c}\text { P-bio } \\
\left(\mu \mathrm{mol} \mathrm{g}^{-1}\right)\end{array}$ & $\begin{array}{c}\text { P-Fe } \\
\left.(\mu \mathrm{mol} \mathrm{g})^{-1}\right)\end{array}$ & $\begin{array}{c}\text { P-CFAP } \\
\left(\mu \mathrm{mol} \mathrm{g}{ }^{-1}\right) \\
\end{array}$ & $\begin{array}{c}\text { P-FAP } \\
\left(\mu \mathrm{mol} \mathrm{g}{ }^{-1}\right)\end{array}$ & $\begin{array}{c}\text { P-org } \\
\left.(\mu \mathrm{mol} \mathrm{g})^{-1}\right)\end{array}$ & $\begin{array}{c}\text { P-T } \\
\left(\mu \mathrm{mol} \mathrm{g}{ }^{-1}\right) \\
\end{array}$ \\
\hline \multirow{5}{*}{ 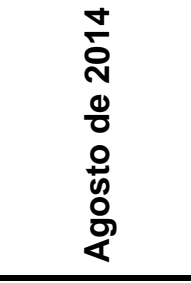 } & Média & 0,33 & 7,82 & 0,51 & 0,65 & 8,44 & 17,74 \\
\hline & DP & $\pm 0,54$ & $\pm 8,51$ & $\pm 0,26$ & $\pm 0,694$ & $\pm 27,69$ & $\pm 34,30$ \\
\hline & Mediana & 0,175 & 4,21 & 0,42 & 0,39 & 1,325 & 10,23 \\
\hline & Mínimo & $<\mathrm{LD}$ & $<L D$ & 0,28 & 0,12 & 0,09 & 1,32 \\
\hline & Máximo & 2,54 & 32,85 & 1,21 & 2,3 & 125,29 & 159,9 \\
\hline \multirow{5}{*}{$\begin{array}{l}\frac{1}{0} \\
\text { N } \\
\frac{0}{0} \\
\frac{0}{\pi} \\
\frac{\pi}{2}\end{array}$} & Média & 3,12 & 12,65 & 2,81 & 0,49 & 3,63 & 22,71 \\
\hline & DP & $\pm 9,84$ & $\pm 9,93$ & $\pm 8,14$ & $\pm 0,44$ & $\pm 8,79$ & $\pm 34,34$ \\
\hline & Mediana & 0,66 & 11,51 & 0,62 & 0,43 & 0,88 & 15,97 \\
\hline & Mínimo & $<\mathrm{LD}$ & 1,00 & 0,21 & $<L D$ & $<L D$ & 2,07 \\
\hline & Máximo & 41,24 & 37,68 & 34,21 & 1,44 & 37,16 & 150,72 \\
\hline
\end{tabular}

$<\mathrm{LD}=$ menor que 0 limite de detecção

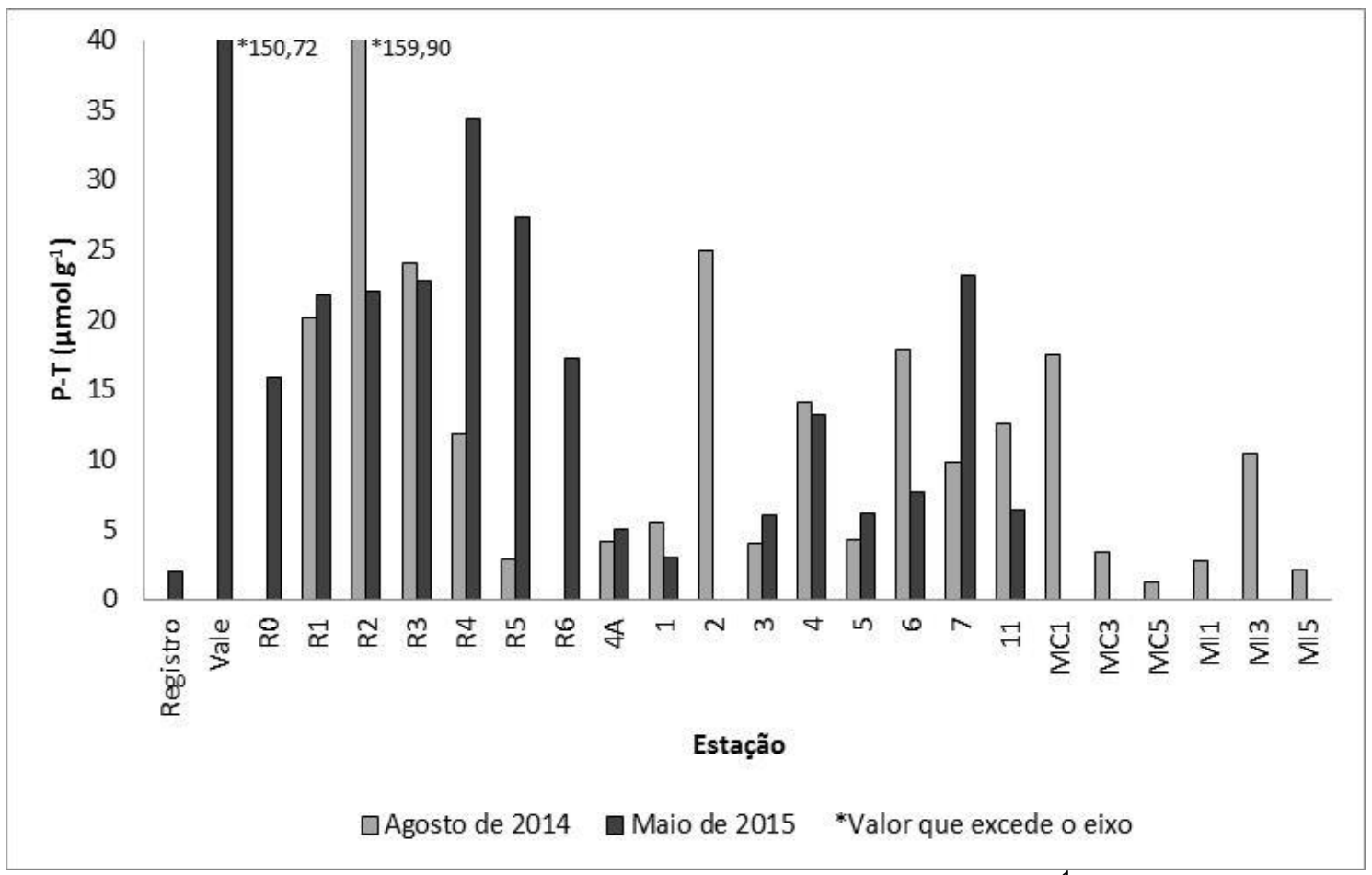

Figura 36. Distribuição espacial das concentrações de P-T $\left(\mu \mathrm{mol} \mathrm{g}{ }^{-1}\right)$ de amostras sedimentares do Rio Guaraú, Rio Ribeira de Iguape e complexo estuarino-lagunar de Cananeia-Iguape (SP), em Agosto de 2014 e Maio de 2015.

No estuário de Santos-São Vicente Berbel et al. (2015) apresentam valores de P-T que variam entre $3,8 \mu \mathrm{mol} \mathrm{g}^{-1}$ e $74,11 \mu \mathrm{mol} \mathrm{g} \mathrm{g}^{-1}$, os autores atribuíram o valor máximo à proximidade do polo industrial da cidade de Cubatão. No complexo estuarino-lagunar de Cananeia-Iguape há uma 
concentração menor de fósforo total no sedimento, exceto pelas estações Vale que apresentou 150,72 $\mu \mathrm{mol} \mathrm{g}^{-1}$ (maio de 2015) e R2 que apresentou 159,90 $\mu \mathrm{mol} \mathrm{g} \mathrm{g}^{-1}$ (agosto de 2014). Estes dois pontos são os mais relacionados com a atividade antrópica.

Meng et al. (2014) no estuário do rio Changjiang (China) encontraram valores que não apresentaram uma variação acentuada, de $15,0 \mu \mathrm{mol} \mathrm{g}^{-1}$ a $21,4 \mu \mathrm{mol} \mathrm{g}{ }^{-1}, 0$ maior valor foi encontrado próximo a despejo de esgoto e advindo da agricultura.

Como pode ser observado na figura 37 a em agosto de 2014, a forma que predominou em relação ao fósforo total foi a P-Fe. Exceto nas estações da plataforma continental, junto às Barras de Cananeia e Icapara que em média houve predominância da fase P-org. Barcellos et al. (2005) observaram na Barra de Icapara a predominância do P-org em relação ao P-T. Berbel (2008) encontrou no inverno, uma predominância da forma P-org no setor sul do complexo estuarino-lagunar de Cananeia-Iguape. Em maio de 2015 (Fig. 37b), a fase predominante no sistema todo foi a P-Fe, compondo mais de $65,0 \%$ do fósforo total. 


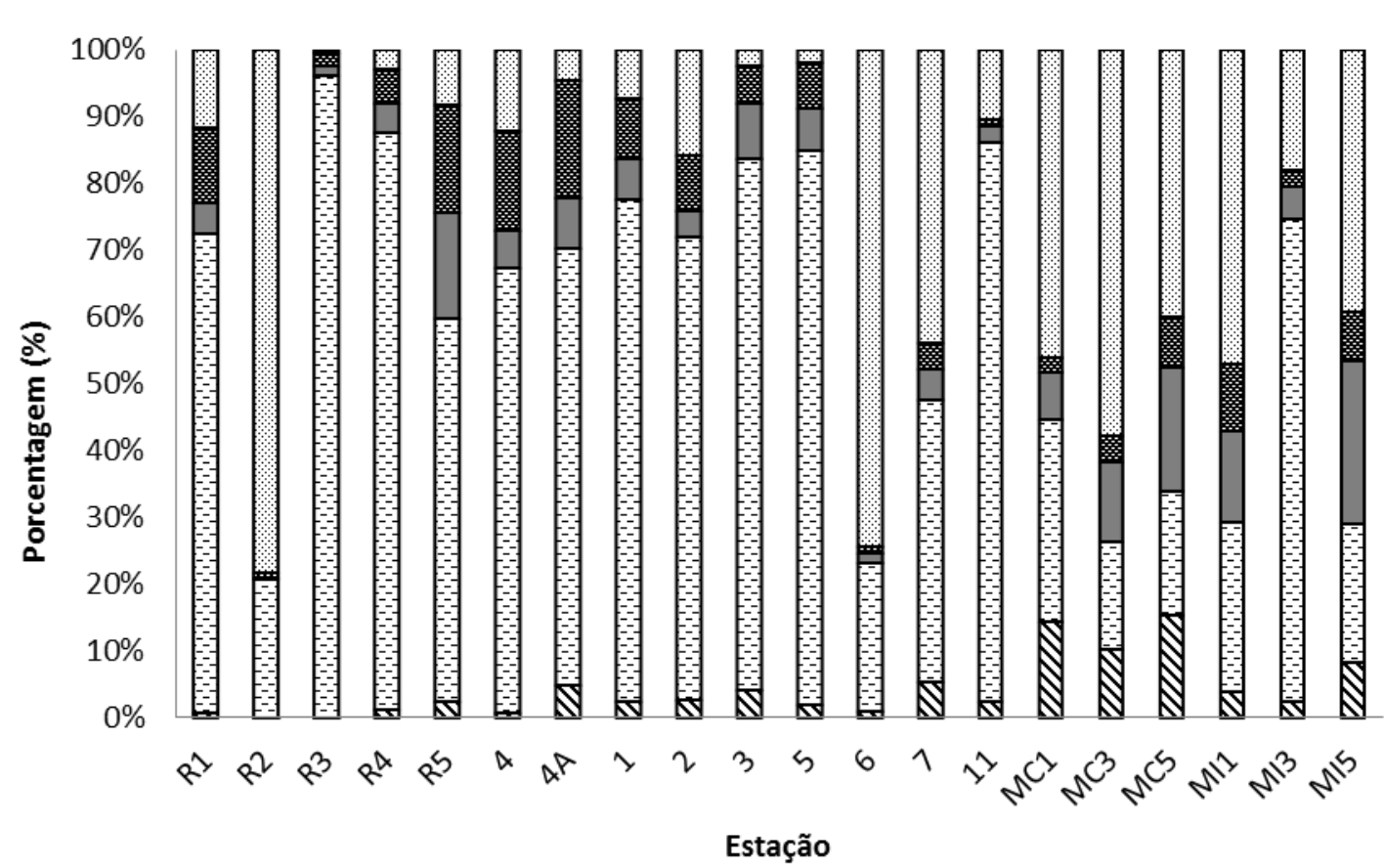

a)

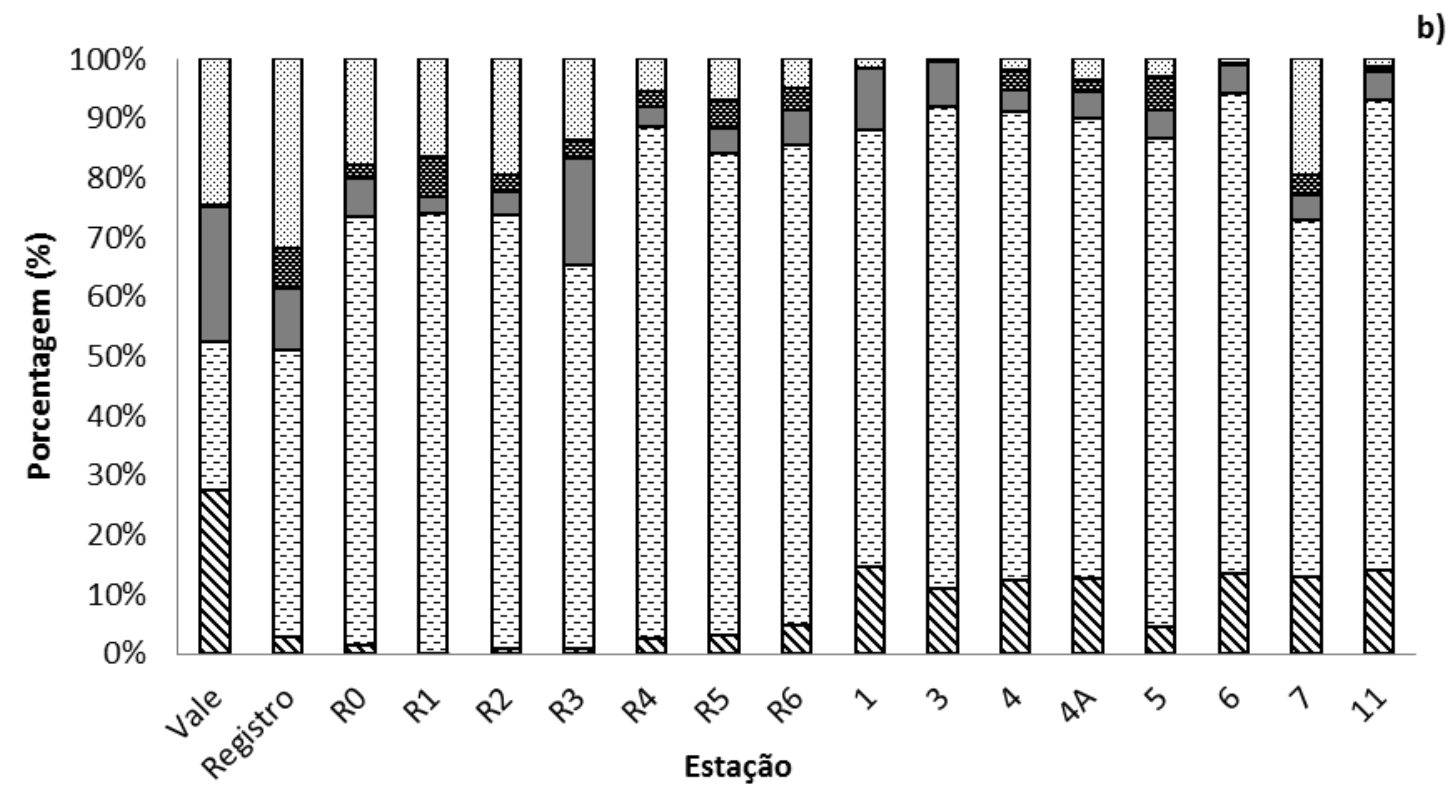

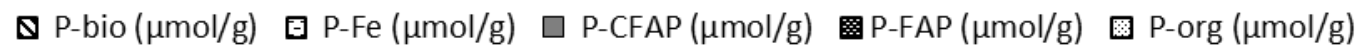

Figura 37. Distribuição espacial das porcentagens das fases P-bio, P-Fe, P-CFAP, P-FAP e Porg em relação ao P-T de sedimentos de superfície do rio Guaraú, rio Ribeira de Iguape ,complexo estuarino-lagunar de Cananeia-Iguape, Barra de Cananeia e de Icapara (SP): a) em agosto de 2014 e b) em maio de 2015.

\subsection{Integração das Formas de Fósforo}

O fósforo é um elemento chave na compreensão da biogeoquímica dos sistemas estuarinos, principalmente quando a bacia de drenagem que alimenta o sistema faz divisa com áreas agrícolas (JENSEN et al., 2006), possui parcela 
de esgoto não tratado e atividades industriais. Sua distribuição no ambiente aquático é controlada por processos físicos, químicos, biológicos e geológicos.

O fósforo inorgânico dissolvido (PID) em agosto de 2014 (ANEXO 1) apresentou correlação significativa positiva com o silicato $(r=0,822)$, o fósforo total dissolvido (PTD) $(r=0,993)$, fósforo inorgânico particulado (PIP) $(r=0,727)$, fósforo orgânico particulado (POP) $(r=0,771)$ e com o P-FAP $(r=0,480)$. Em relação à correlação positiva do PID com o silicato e o P-FAP, pode-se inferir que há similaridade na fonte destes parâmetros para o sistema estuarino, pois os três possuem sua fonte ligada aos processos de intemperismo e erosão continental, podendo ocorrer de forma antrópica. A fase dissolvida do fósforo apresentou correlação com a particulada, isso se deve provavelmente às relações de adsorção/desorção que ocorrem na coluna d'água, esse padrão também foi observado em maio de 2015 (PID e PIP $r=0,575$; PID e POP $r=$ 0,548; e PID e PTP r= 0,704) (Anexo 2).

Foram encontradas correlações significativas negativas do PID com a salinidade $(r=-0,810)$, material particulado em suspensão $(r=-0,492)$, material particulado orgânico em suspensão $(r=-0,573)$ e porcentagem de silte $(r=-$ 0,469). A salinidade possui distribuição inversa com o PID, pois no complexo estuarino-lagunar de Cananeia-Iguape o fósforo é diluído ao longo do gradiente de salinidade, como também pode ser observado no diagrama de dispersão com a linha de diluição teórica (Fig. 38).

O MPS pode estar relacionado inversamente ao PID, nesta área de estudo, devido à qualidade do material particulado entre os setores norte e sul. Já o silte, está relacionado à locais de deposição de finos, que podem ocorrer em áreas com baixa hidrodinâmica, em que o PID pode passar da forma dissolvida para a particulada. 


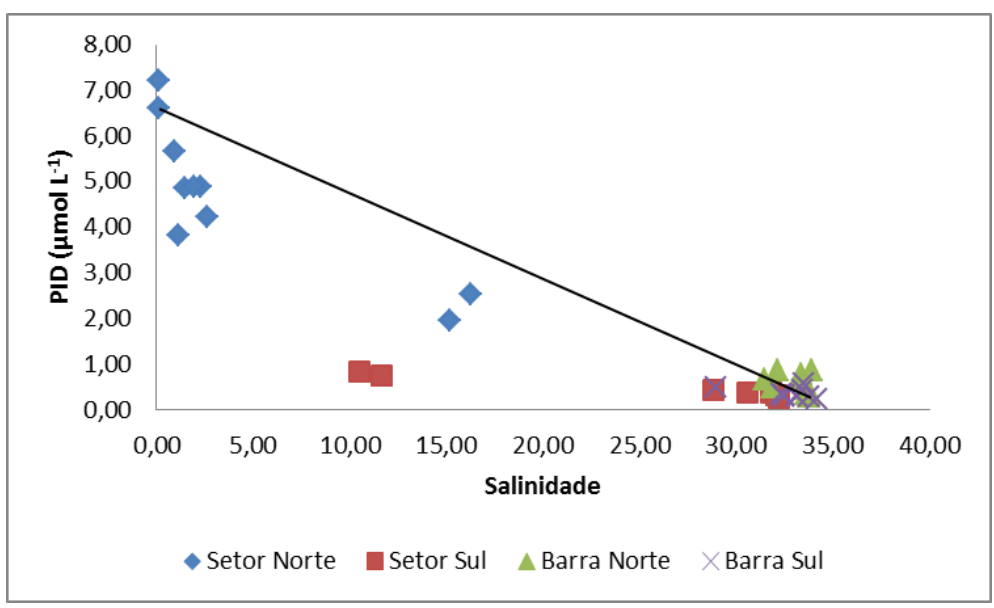

Figura 38. Diagrama de dispersão de fosfato inorgânico dissolvido - PID $\left(\mu \mathrm{mol} \mathrm{L}^{-1}\right)$ com relação à salinidade: agosto de 2014 no rio Ribeira de Iguape, sistema estuarino-lagunar de CananeiaIguape, Barras de Cananeia (Sul) e de Icapara (norte) (SP).

O fósforo orgânico dissolvido (POD) apresentou correlação significativa, somente na coleta de 2014 (Anexo 1), com a argila $(r=0,885)$, indicando que nos locais que há deposição de material fino houve a presença de POD na coluna d' água.

A fase de fósforo inorgânico particulado (PIP), em agosto de 2014 (Anexo 1) apresentou correlação significativa positiva com oxigênio dissolvido (OD) $(r=0,541)$, turbidez $(r=0,503)$, silicato $(r=0,802)$, PID ( $r=0,727)$, PTD $(r=$ $0,725)$, clorofila-a (cl-a) $(r=0,560)$, fósforo orgânico particulado (POP) $(r=$ $0,587)$, fósforo total particulado (PTP) $(r=0,822)$ e fósforo ligado à fluorapatita (P-FAP) $(r=0,440)$ essa correlação provavelmente está ligada à fonte, pois o $P$ FAP constitui a fase não reativa do fósforo sedimentar (RUTTENBERG, 2005), está ligada aos minerais primários como quartzo e feldspato (MENG et al., 2014).

O PIP se correlaciona com a turbidez positivamente, pois nas profundidades com maior turbidez há também uma maior concentração do fósforo particulado, como por exemplo, na estação 2 onde ocorre a zona de máxima turbidez do estuário $(62,50 \mathrm{NTU})$ e valores altos de PIP $\left(42,51 \mu \mathrm{mol} \mathrm{L}^{-}\right.$ $\left.{ }^{1}\right)$.

As três formas de fósforo particulado analisadas por este trabalho apresentaram correlação significativa negativa com a salinidade, PIP ( $r=$ $0,813)$, POP $(r=-0,741)$ e PTP $(r=-0,853)$, isso provavelmente ocorre devido a processos de diluição da água doce pela água do mar e a processos de 
adsorção do fósforo no material em suspensão em baixas salinidades. Lin et al. (2012) aponta que no estuário do rio Jiulong as concentrações de PTP, são mais elevadas em áreas com menor influência da salinidade e menos elevadas em áreas com maior influência da salinidade. Isso ocorre pois baixas salinidades facilitam o processo de adsorção do P (PRASTKA et al, 1998).

Em agosto de 2014 (Anexo 1), o POP também apresentou correlação significativa com o fósforo total particulado (PTP) $(r=0,944)$, essa correlação ocorre pois na maioria das estações POP compõem mais de $50 \%$ do fósforo total particulado. Esse padrão também foi encontrado em maio de 2015 (Tab. 11), com $r=0,785$, nesta camapanha a porcentagem de PIP foi maior a do POP, em realção ao PTP, na maioria das estações de coleta.

O fósforo total particulado, em agosto de 2014 (Anexo 1), apresentou correlação significativa positiva com OD $(r=0,542)$, silicato $(r=0,839)$ e PTD $(r=$ $0,862)$. Além da salinidade o PTP também apresentou correlação significativa negativa com o pH $(r=-0,839)$ e com o MPOS $(r=-0,579)$. $O \mathrm{pH}$ apresentou correlação negativa forte, e está associada com a diferença de $\mathrm{pH}$ entre a água doce e a salina. Entre o PTP e o MPOS, a correlação ocorreu provavelmente devido às concentrações mais altas de fósforo total particulado, estarem relacionadas com valores mais baixos de MPOS.

O fósforo contido nos sedimentos é regido por processos biogeoquímicos que ocorrem na água intersticial contida nos poros sedimentares e também na coluna d' água.

O fósforo biodisponível (P-bio) em agosto de 2014 (Anexo 1) apresentou correlação significativa negativa com o OD $(r=-0,526)$, nas estações em que $O \mathrm{OD}$ foi mais elevado a concentração de $P$-bio foi menor, devido provavelmente ao consumo de P-bio para a produção, como ocorreu na estação 4A que apresentou valor baixo de P-bio $\left(0,24 \mu \mathrm{mol} \mathrm{g}^{-1}\right)$, valor mais alto de OD $\left(5,72 \mathrm{~mL} \mathrm{~L}^{-1}\right)$ e um aumento na produção (clorofila-a igual a $13,74 \mathrm{mg} \mathrm{m}^{-}$ $\left.{ }^{3}\right)$. E apresentou correlação significativa positiva com o P-CFAP $(r=0,683)$, podendo indicar que a fonte destas fases é a mesma, provavelmente 0 aumento de P-CFAP pode ser favorecido pela presença de P-bio, que está sendo adsorvido à apatita biogênica ou formando a apatita autigênica mineral. Em maio de 2015 (Anexo 2), não houve correlação significativa do P-bio com os demais parâmetros. 
$\mathrm{O}$ fósforo ligado ao ferro ( $\mathrm{P}-\mathrm{Fe}$ ), foi a fração de $\mathrm{P}$ sedimentar predominante no complexo estuarino-lagunar de Cananeia-Iguape. Esta fase de $P$ apresentou, em agosto de 2014 (Anexo 1), correlações positivas significativas com o silcato $(r=0,522)$, o P-FAP $(r=0,512)$, o P-org $(r=0,685)$ e o P-T ( $r=0,813$ ). Em maio de 2015 (Anexo 1) também houve correlação positiva significativa do P-Fe entre P-FAP $(r=0,815)$, P-org $(r=0,595)$ e P-T $(r=$ $0,980)$ A fonte de silicato e P-FAP está relacionada à erosão continental, que pode em algumas estações (como a estação 11) ter sido um dos fatores responsáveis pelo aumento de $\mathrm{P}$-Fe sedimentar. O fósforo total possui uma correlação forte com o $\mathrm{P}-\mathrm{Fe}$, devido provavelmente ao fósforo ligado ao ferro ser a fase predominante (mais de $50 \%$ ) de fósforo em relação ao P-T.

A fase P-FAP, em agosto de 2014 (Anexo 1), esteve correlacionada positivamente significativamente com a turbidez $(r=0,492)$, silicato $(r=0,627)$, PID $(r=0,480)$, PTD $(r=0,514)$, PIP $(r=0,440)$ e P-CFAP $(r=0,625)$. Os parâmetros turbidez, silicato, PID, PTD e PIP estiveram todos com concentrações mais elevadas no setor norte do complexo estuarino-lagunar de Cananeia-Iguape, e sofreram diminuição no sentido do setor sul, isto pode indicar que o P-FAP também está passando por este processo. Em maio de 2015 (Anexo 2), houve correlação do P-FAP somente com o P-T $(r=0,845)$

Como pode ser observado, no geral as formas de fósforo (dissolvida, particulada e sedimentar) se correlacionaram biogeoquimicamente e sofreram grande influência da água doce e dos materiais provenientes do rio Ribeira de Iguape. Para entender melhor os processos biogeoquímicos que regem este sistema estuarino foi realizado o cálculo do $\triangle$ PID (PRASTKA et al., 1998), que mensura a quantidade de PID que está adsorvendo e virando PIP (valores positivos), e/ou a quantidade de PIP que está dessorvendo e virando PID (valores negativos). A utilização deste modelo de equilíbrio é indicada somente para ambientes estuarinos.

$\mathrm{Na}$ campanha de agosto de 2014 (Tab. 9), no complexo estuarinolagunar de Cananeia-Iguape, pode-se observar que em todas as estações neste período do ano estiveram com processo de adsorção do PID, ou seja, o fósforo inorgânico dissolvido que passou para a forma particulada. O processo de adsorção também esteve atuante em diversas estações de coleta em maio de 2015 (Tab. 9), porém nas estações mais próximas ao rio Ribeira de Iguape, 
ocorreu um aumento no processo de dessorção (-56 \% na estação 5 e -8 \% na estação 3).

Tabela 9. Valores de $\triangle \mathrm{PID}$ e \%DIP com as estações estuarinas (1-11) do complexo estuarinolagunar de Cananeia-Iguape (S), agosto de 2014 e maio de 2015

\begin{tabular}{|c|c|c|c|c|c|}
\hline Campanha & Estação & Salinidade & $\Delta$ DIP & \%PID & Processo \\
\hline \multirow{7}{*}{ 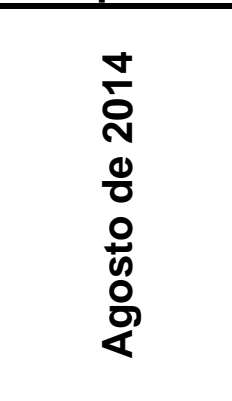 } & 1 & 15,70 & 7,89 & 87 & adsorção \\
\hline & 2 & 2,20 & 7,69 & 85 & adsorção \\
\hline & 3 & 1,80 & 8,12 & 90 & adsorção \\
\hline & 5 & 0,08 & 5,30 & 59 & adsorção \\
\hline & 6 & 11,07 & 7,28 & 81 & adsorção \\
\hline & 7 & 32,03 & 5,73 & 64 & adsorção \\
\hline & 11 & 29,69 & 5,08 & 56 & adsorção \\
\hline \multirow{7}{*}{ 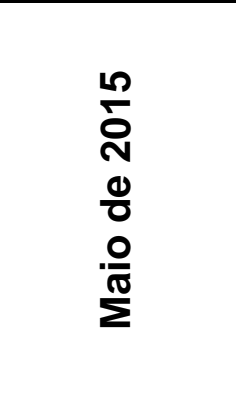 } & 1 & 4,7 & 1,80 & 41 & adsorção \\
\hline & 2 & 0,16 & 3,20 & 72 & adsorção \\
\hline & 3 & 0,04 & $-2,50$ & -56 & dessorção \\
\hline & 5 & 0,04 & $-0,40$ & -8 & dessorção \\
\hline & 6 & 7,99 & 1,00 & 23 & adsorção \\
\hline & 7 & 17,07 & 1,10 & 25 & adsorção \\
\hline & 11 & 24,25 & 1,40 & 32 & adsorção \\
\hline
\end{tabular}

Segundo Prastka et al. (1998) este comportamento de retenção ocorre em sistemas estuarinos que sofrem influência antrópica acentuada. No entanto estuários que recebem menor influência antrópica tendem a liberar fósforo para a plataforma continental (op cit.). O complexo estuarino-lagunar de CananeiaIguape é apontado por Coelho (2011), Eschrique (2011) e por Agostinho (2015), como retentor de fósforo.

De acordo com a figura 39, pode-se ter uma melhor noção do ciclo biogeoquímico do fósforo no complexo estuarino-lagunar de Cananéia-Iguape, bem como sua diferença nos processos sazonais entre inverno e outono, tendo como ponto de partida a inserção de partículas e água através do Valo Grande.

O rio Ribeira de Iguape, em agosto de 2014, apresentou em média 9 $\mu \mathrm{M}$ de PID, $1 \mu \mathrm{M}$ de POD, $60 \mu \mathrm{mol} \mathrm{g}^{-1}$ de PIP e $39 \mu \mathrm{mol} \mathrm{g}^{-1}$ de POP, ao desaguar no sistema parte da água caminha em direção ao setor norte (estação 3) e parte em direção ao setor sul (estação 5). Da foz do rio para a estação 3, houve a adsorção de $90 \%$ do PID que entrou no sistema, aumentando o valor de PIP e também servindo de fonte para a produção 
primária, com um grande aumento de POP (para $62 \mu \mathrm{mol} \mathrm{g} \mathrm{g}^{-1}$ ) e uma diminuição do POD (para 0,3 $\mu \mathrm{M}$ ), parte deste material é decantado, pois no sedimento houve presença de silte e de P-T. Neste o gradiente de salinidade foi baixo $(1,8)$, influênciando positivamente no processo de adsorção. De acordo com a porcentagem de $\triangle \mathrm{PID}$, pode-se observar que em águas menos salinas (salinidade entre 1,0 e 2,0), ocorre a maior adsorção do PIP (Tab. 9).

Em relação ao rio para a estação 2, ocorreu $85 \%$ de adsorção do PID (que entrou no sistema via Valo Grande). Entretando em relação a estação 3 ocorreu o processo inverso de aumento das concentrações da forma dissolvida e diminuição da particulada. Neste ponto ocorreu a ZMT, que depositou material fino, esse processo de deposição é verificado pela presença de $25 \%$ de silte no sedimento e pelo aumento nas concentrações de P-T $\left(25 \mu \mathrm{mol} \mathrm{g}{ }^{-1}\right)$. Houve também a presença de produção primária acentuada com clorofila 11 $\mathrm{mg} \mathrm{m}^{-3}$ na superfície. $\mathrm{O}$ valor da salinidade nesta estação favorece a adsorção de PIP ao material particulado em suspensão.

Caminhando do rio para a estação 1 , observou-se que o processo de adsorção atuou em $87 \%$ do PID proveniente do rio Ribeira de Iguape, diminuindo a concentração de PID. Provavelmente há também influência da produção primária (clorofila $10,0 \mathrm{mg} \mathrm{m}^{-3}$ na superfície), com aumento de $\mathrm{POD}$ e de POP. As concentrações de fósforo encontradas na Barra de Icapara são menos elevadas do que as observados no sistema estuarino, portanto no setor norte os processos de adsorção estavam retendo o fósforo no estuário estudado.

Do rio Ribeira de Iguape para a estação 5, ocorreu o processo de adsorção em 59 \% do PID, ocorrendo uma diminuição no PID e um aumento do PIP e do POP, nesta estação devido ao momento de maré estar no auge da maré enchente, onde também ocorre ressuspensão de sedimentos que contribuem na concentração de particulados.

Entre o rio e a estação 6, foi encontrado o processo de adsorção atuando em 81 \% do PID proveniente do rio via Valo Grande. O que acarretou em uma diminuição expressiva de PID (de 7,0 $\mu \mathrm{M}$ para 1,0 $\mu \mathrm{M}$ ) e um aumento de PIP , POP e P-T no sedimento. É importante ressaltar que entre a estação 5 e a 6, existe um ponto denominado "Pedra do Tombo" no qual ocorre processo de adsorção intenso, sendo classificado como uma ZMT (PISETTA, 2010; 
BARCELLOS, 2005). Segundo Pisetta (2010) cerca de $20 \%$ do material particulado advindo do Valo Grande passa pela Pedra do Tombo e atinge o mar de Cananeia. Além disso, está ocorrendo deposição de material particulado, principalmente na forma orgânica, demostrado pelos altos valores de P-T e P-org, e pela presença de silte.

Em relação ao rio a estação 7, sofre adsorção de $64 \%$ do PID para a fase particulada e a estação 56 \% do PID. Entre as estações 6 e 7, e 7 e 11, ocorre a dessorção de PIP para PID, que por sua vez é consumido pelo fitoplâncton dando origem ao POP, que representou mais de 75 \% do PTP nas duas estações, esse processo também indicado por um aumento na concentração de clorofila-a $\left(12,56 \mathrm{mg} \mathrm{m}^{-3}\right.$ na estação 7 e $9,61 \mathrm{mg} \mathrm{m}^{-3}$ na estação 11). 


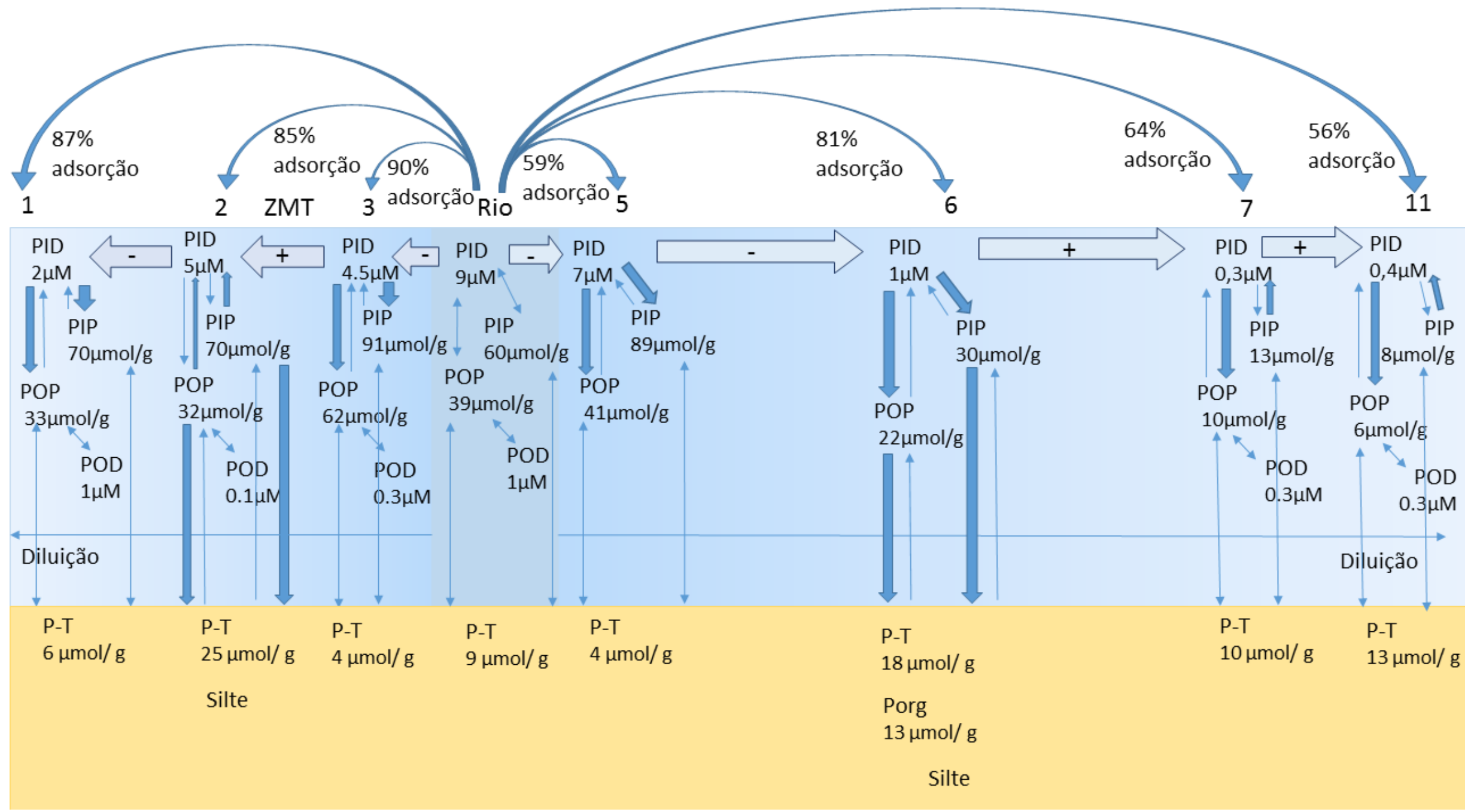

Figura 39. Representação do ciclo do fósforo no complexo estuarino-lagunar de Cananeia-lguape (SP) no transecto N-S, com base na porcentagem de adsorção do PID (\%PID) utilizando os dados de Agosto de 2014. 
Em maio de 2015 (Fig.40), o rio Ribeira de Iguape, apresentou concentração média de PID em 4,4 $\mu \mathrm{M}$, POD 0,3 $\mu \mathrm{M}$, PIP $72 \mu \mathrm{mol} \mathrm{g}{ }^{-1}$, POP 21 $\mu \mathrm{mol} \mathrm{g}^{-1}$ e P-T $16 \mu \mathrm{M}$, estes dados foram considerados como a entrada no modelo para o cálculo da porcentagem de remoção de PID. Em relação à campanha anterior, os níveis de material dissolvido e particulado transportados pelo rio foram menores.

Da foz do rio em direção a estação 3, ocorreram processos de adição de PID (remineralização da matéria orgânica e/ou dessorção) de 55\% do PIP que entrou no sistema, aumentando o valor de PID para $5 \mu \mathrm{M}$. O valor de PIP, aumentou para $68 \mu \mathrm{mol} \mathrm{g}^{-1}$ e o de POP para $25 \mu \mathrm{mol} \mathrm{g}{ }^{-1}$, provavelmente devido ao processo de ressuspensão de sedimentos de fundo também indicada pela diminuição de P-T.

Entre o rio Ribeira de Iguape e a estação 2, ocorreu o processo de adsorção de $72 \%$ do PID inserido pelo rio, este aumento pode ter sido ocasionado pela presença da zona de máxima turbidez do estuário (ZMT), observada pelo aumento nas concentrações de $\mathrm{P}$ particulado (PIP e POP). Parte do fósforo dissolvido também foi utilizado na produção primária, presença de POD $(0,3 \mu \mathrm{M})$ e aumento de clorofila $\left(3,83 \mathrm{mg} \mathrm{m}^{-3}\right)$.

$\mathrm{Na}$ estação 1 (próxima à Barra de Icapara) em relação ao rio, houve uma remoção menos acentuada do PID (41\%). Em relação a estação 2 ocorrem processos de dessorção, acarretando na diminuição de PIP. Há também nesta estação uma produção primária, observada pela presença de clorofila-a $\left(1,23 \mathrm{mg} \mathrm{m}^{-3}\right)$ e aumento do POD $(0,7 \mu \mathrm{M})$.

Do rio em direção à Barra de Cananeia, na estação 5 ocorreu uma leve adição de PID, evidenciada pelo \%PID no valor de $-8 \%$. Há, portanto, entre a foz do rio e a estação 5 o aumento de PID para $5 \mu \mathrm{M}$, com manutenção de altos valores de fósforo inorgânico particulado e diminuição no valor de P-T sedimentar, que podem sugerir a presença de ressuspensão de material de fundo.

Entre a foz do rio no sistema estuarino e a estação 6 , ocorreu uma adsorção de $23 \%$ de PID. Este valor parece baixo, porém entre as estações 5 e 6 provavelmente ocorre um intenso processo de remoção de PID, devido a presença da ZMT localizada próximo à Pedra do Tombo (PISETTA, 2010). Outra parcela de fósforo dissolvido também pode ter sido removida pela 
produção primária (clorofila-a na camanada de fundo, $\sim 12 \mathrm{mg} \mathrm{m}^{-3}$ ). Houve também a diminuição dos valores de PIP e POP enquanto no sedimento ocorreu aumento de P-T indicando processo deposicional.

$\mathrm{Na}$ estação 7 em relação ao rio, ocorreu remoção de PID, $25 \%$ de adsorção. Porém houve diminuição nas concentrações dos particulados (PIP e POP), isto pode indicar que entre o rio e a estação 7 há uma menor influência dos materiais provenientes da bacia de drenagem através do canal do Valo Grande em relação às estações ao norte deste ponto, e que o MPS nesta região do estuário é de qualidade diferente do que o do setor norte, como indicado por diversos autores que estudaram o complexo estuarino-lagunar de Cananeia-Iguape (BARCELOS, 2005; PISETTA, 2010; COELHO, 2011; ESCHRIQUE, 2011; BASTOS, 2014; AGOSTINHO, 2015). Neste ponto ocorreu aumento de P-T no sedimento e a presença de silte e argila podem indicar que estão ocorrendo processos de sedimentação.

Entre o rio e a estação 11, ocorreu processo de adsorção em 32 \% do PID inserido no sistema estuarino via bacia de drenagem, evidenciado pela diminuição de PID e aumento do PIP. Houve um aumento de POP e a presença de $\mathrm{POD}$ indicando atividade biológica. 


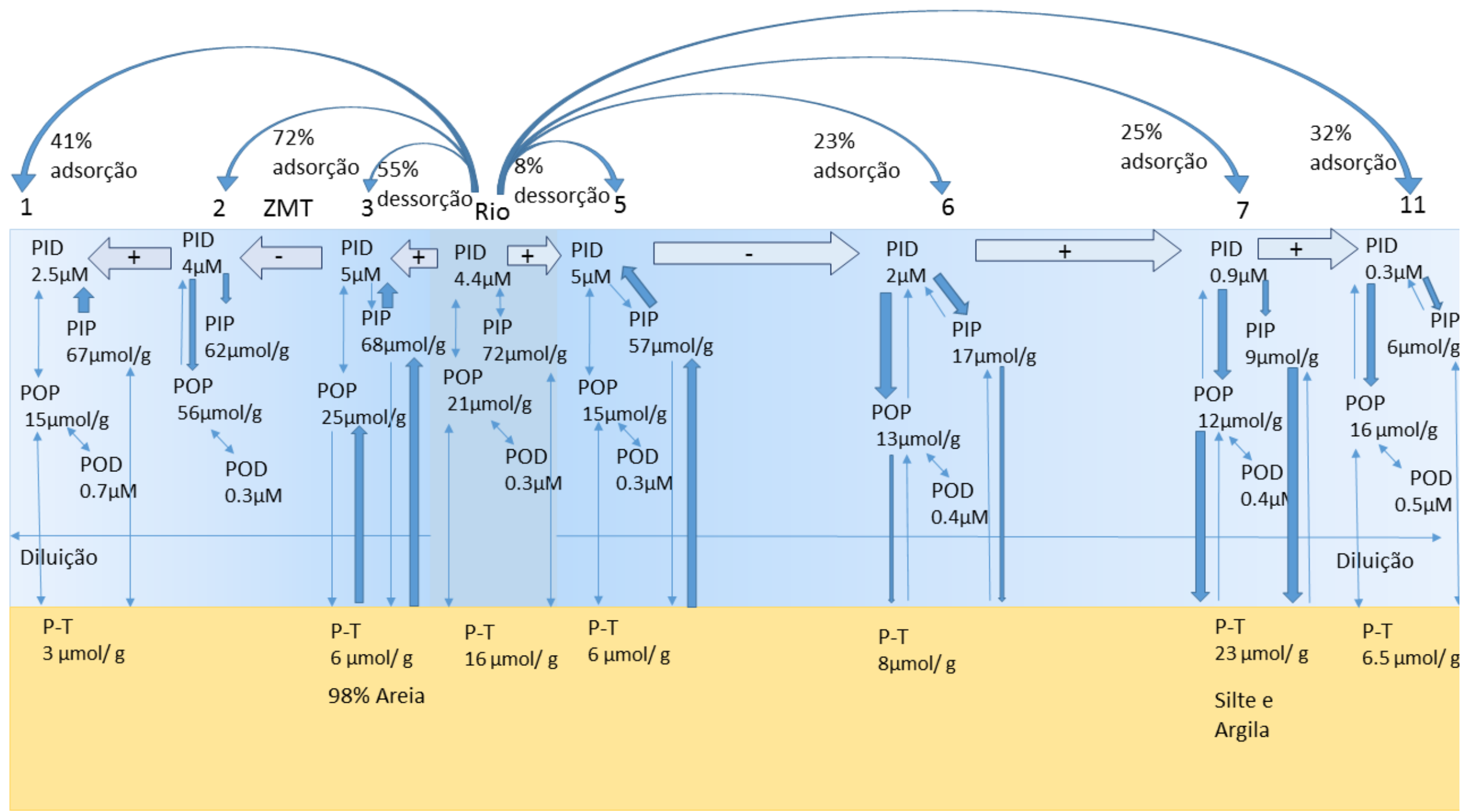

Figura 40. Representação do ciclo do fósforo no complexo estuarino-lagunar de Cananeia-lguape (SP) no transecto N-S, com base na porcentagem de adsorção do PIP (\%PID) utilizando os dados de Maio de 2015. 
Como já apontado por este trabalho, por CETESB (2016) e por Agostinho (2015), a principal fonte de fósforo para o rio Ribeira de Iguape é o afluente rio Jacupiranga que recebe contribuições da mineração de fluorapatita na cidade de Cajati. Esta inserção de fósforo ocorre constantemente durante o ano, entretanto os fatores sazonais influenciam nas concentrações de fósforo que atingem o sistema estuarino. No período do inverno de 2014 houve uma maior concentração de PID em relação ao outono de 2015, provavelmente devido à diminuição da diluição pluvial. 


\section{Conclusão}

- O silicato e o fosfato são elementos nutrientes que possuem como fonte a bacia de drenagem continental, de modo que o acompanhamento do comportamento do silicato no sistema hídrico auxilia a compreensão do ciclo do fósforo em termos de inserção e remoção, ou seja ciclagem biogeoquímica e interferências antrópicas.

- No caso dos rios, a fonte de silicato via drenagem continental foi muito alta nos dois períodos evidenciado sua efetiva contribuição ao sistema hídrico. Nos dois períodos foi observada uma importante remoção de silicato principalmente em agosto de 2014, além da diluição contra o gradiente de salinidade.

- Quanto ao PID, observou-se valores acima de $10 \mu \mathrm{mol} \mathrm{L} \mathrm{L}^{-1}$ no setor norte do estuário, considerados muito altos em sistemas naturais não impactados, esses valores foram encontrados tanto nas estações rio Ribeira de Iguape, quanto na estação Cajati. Valores acima de $10 \mu \mathrm{mol} \mathrm{L}^{-1}$ extrapolam os limites naturais encontrados em estuários sadios, sendo similares aos valores encontrados em sistemas com histórico de poluição.

- Os valores de PID encontrados no norte do sistema, provenientes do rio foram altos e apresentaram um comportamento de diluição e remoção em direção ao sul mais efetivo que em direção a Barra de Icapara. No setor sul, a diluição ainda está efetiva atingindo valores naturais como na água do mar, mostrando que o sistema está atuando no tamponamento da saída do PID, mas essa capacidade pode ser alterada a qualquer momento, colaborando ao maior impacto ambiental.

- Os valores de POD, de um modo geral, foram baixos nos rios, mostrando que a principal fonte é inorgânica e a contribuição maior deve ser da produtividade natural do sistema estuarino e marinho adjacente. A indicação de contribuição de POD via esgoto ainda é pouco significativa na entrada no sistema estuarino diante da entrada de formas inorgânicas, mostrando sinal no Canal do Valo Grande, mas que não elimina transformação de POD em PID na indicação 
desta contribuição antrópica ao sistema em outros pontos. Assim, o POD aponta para a contribuição de esgotos nos rios, porém o PTD mostra a maior fração em PID, que aponta outra fonte de entrada, no caso dos resíduos da mineração é o mais indicado.

- O material particulado em suspensão tem papel assegurado na ciclagem do $P$ e ele apresentou valores menores no norte do sistema associado à descarga do rio e a maior turbidez porque a qualidade do material neste setor corresponde à fração fina de particulados. Enquanto no sul do sistema, os valores foram maiores, porém associados à contribuição dos processos de biossíntese de matéria orgânica (fotossíntese é mais intensa no sul) e ressuspensão de sedimentos pela ação da maré. Assim, a fração fina tem uma atuação mais intensa no setor norte do sistema, participando no sequestro de $\mathrm{P}$, o que mostrou os valores de PID associado à maior fração fina em suspensão encontrada no setor norte. Essa associação ao material em suspensão facilita a deposição do $P$ particulado junto ao sedimento. A baixa concentração de POP no sistema corrobora com a menor influência de aportes por esgotos (efluentes domésticos nesse sistema). No caso, no sul do sistema, menos impactado, o valor de POP e sua variação sazonal foi mais indicativa da produção e disponibilidade de matéria orgânica proveniente do estado de trófico natural.

- A avaliação da composição e granulometria dos sedimentos nos diferentes setores do sistema permitem não só o conhecimento da hidrodinâmica que neles atua, mas também fornece informações que alimentam o conhecimento dos ciclos biogeoquímicos dos elementos, nesse caso do P. A fração fina foi observada em maior quantidade no setor norte do sistema, devido a forte contribuição do material em suspensão carreado pelo rio e depositado no sistema estuarino. Na fração fina houve frequente associação com a maior fração orgânica e carbonato biodetrítico.

- A fração P-bio no sedimento é muito sensível à presença de fração fina no sedimento e também a mudança de $\mathrm{pH}$, ocasionada pela maior influência de água salina, atuando na deposição a partir da coluna d' água pelo processo de 
floculação. Assim um ambiente suscetível a modificação de $\mathrm{pH}$, devido a maior influência da entrada de água doce ou de alterações ambientais localizadas, podem mostrar alteração na forma P-bio, sendo que ela esteve mais disponível nos sedimentos de rio mais próximos ao Valo Grande e no próprio Valo. Isso também ocorre no Sul do sistema, em situações de extremas de salinidade. Esta forma de $\mathrm{P}$ é bastante móvel nos sistemas ambientais, podendo ser usada para acusar processos como a biodisponibilização para a assimilação e a mudança de salinidade ao longo do sistema como uma resposta a alteração ambiental, porém ela é dependente de muitos fatores ambientais, mostrando maior correlação com o P-CFAP no inverno, o que confirma apenas a sua complexidade.

- A fração P-Fe teve correspondência com a deposição e presença de material fino proveniente de erosão continental, encontrada em maior quantidade no sedimento sob os rios e também abaixo da zona de máxima turbidez, podendo ser utilizado no acompanhamento do aumento dos processos de erosão, devido ao impacto do uso e ocupação do solo nas margens dos rios ou a qualidade do material nele introduzido. Esta fase do fósforo apresentou menores valores no sul do sistema, podendo ser um excelente parâmetro para acompanhar o efeito da disposição de material particulado no setor norte sobre o setor sul e do efeito da erosão sob as proximidades da Barra de Cananéia.

- No caso P-FAP sua propriedade de estar mais associada à fração textura média e grossa dos sedimentos, de modo a apontar locais com maior hidrodinâmica enquanto o Porg deveria estar acusando a presença de matéria orgânica e acabou associado aos valores de P-Fe, sobretudo no sistema norte, porém acusou zona de produção junto às estações 5,6 e 7 que estão no meio do sistema e tem maior atividade biológica.

- Com o estudo das diferentes formas e partição do P é possível diagnosticar de modo mais completo os agentes que estão contribuindo aos processos de alteração ambiental, através do desequilíbrio entre as formas no seu ciclo biogeoquímico. Esse desequilíbrio é a resposta da introdução ou alteração nos processos de adsorção, dessorção, assimilação, retenção e exportação, o que 
favorece o monitoramento ambiental. No presente trabalho, o desequilíbrio do PID foi o principal elemento de desequilíbrio, devido a sua introdução no sistema.

- Portanto o complexo estuarino-lagunar de Cananeia-lguape age como um filtro, impedindo que altas concentrações de fósforo atinjam o oceano adjacente. Isso fica demonstrado pela predominância de processos de adsorção e sedimentação que retém o material no interior do estuário. É interessante observar que durante períodos em que o aporte de fósforo pelo rio é bastante elevado como ocorreu em agosto de 2014 os processos de adsorção se tornam ainda mais proeminentes. 


\section{Referências Bibliográficas}

AGOSTINHO, K. L. Estudo do Nitrogênio e do Fósforo (N e P) no setor norte do Complexo Estuarino-Lagunar de Cananeia-Iguape (SP) considerando as condições naturais do sistema e a influência dos aportes antrópicos. 2015. 107 p. Dissertação (Mestrado em Oceanografia Química) Instituto Oceanográfico. Universidade de São Paulo, São Paulo.

AGUIAR, V.M.C. Variação espacial e temporal das características biogeoquímicas do fósforo e do chumbo e transporte de propriedades no sistema estuarino de Santos/S. Vicente e na porção sul do Complexo Estuarino-Lagunar de Cananéia-Iguape (São Paulo). 2005. 243p. Tese (Doutorado em Oceanografia Química e Geológica) - Instituto Oceanográfico. Universidade de São Paulo, São Paulo.

AGUIAR, V.M.C.; BRAGA, E.S. 2007. Seasonal and tidal variability of phosphorus along a salinity gradient in the polluted estuarine system of Santos/São Vicente - São Paulo, Brazil. Marine Pollution Bulletin. v.54. p.464-488.

ALLANSON, B.R.; WINTER, D. 1999. Chemistry. In: Estuaries of South Africa. pp. 53-89.

AMINOT, A.; CHAUSSEPIED, M. 1983. Manuel des analyses chimiques en milieu marin. CNEXO. Brest. 395p.

ARMSTRONG, F. A. J.; WILLIAMS, P. M.; STRICKLAND, J. D. H. 1968. Photo-oxidation of organic matter in sea water by ultraviolet radiation, analytical and other applications. Nature. v. 211. p. 481- 483.

ARMSTRONG, F.A.J.; TIBBITTS, S. 1968. Photochemical combustion of organic matter in sea water, for nitrogen, phosphorus and carbon determination. J. Mar Biol Assoc. UK, v.48, p.143-152.

ASPILA, K.I.; AGEMIAN, H.; CHAU, A.S.Y. 1976. A semi-automed Method for the Determination of Inorganic, Organic and Total Phosphate in Sediments. Analyst. V.101, p.187-197. 
BARCELLOS, R.L.; BERBEL, G.B.B.; BRAGA, E.S.; FURTADO, V.V. 2005. Distribuição e características do fósforo sedimentar do sistema estuarino lagunar Cananeia-Iguape, Estado de São Paulo, Brasil. Geochimica Brasiliensis. V. 19, n. 1, p. 22-36.

BARCELOS, R.L. Distribuição da matéria orgânica sedimentar e o processo sedimentar atual no Sistema Estuarino-Lagunar de CananeiaIguape (SP). 2005. 2 vols. Tese (Doutorado) - Instituto Oceanográfico, Universidade de São Paulo, São Paulo.

BARRERA-ALBA, J.J.; GIANESELLA, S.M.F.; MOSER, G. A. O.;SALDANHACORRÊA, F.M. 2009. Influence of allochthonus organic matter on bacterioplankton biomass and activity in a eutrophic, sub-tropical estuary. Estuarine, Coastal and Shelf Science. v.82, 84-94 p.

BASTOS, A.T.C.C. Estudo do Ciclo Biogeoquímico do silício em diferentes sistemas marinhos como ferramenta para identificação de alterações ambientais de oriegem natural e/ou antrópica. 2014. 104 p. Dissertação (Mestrado em Oceanografia Química) - Instituto Oceanográfico. Universidade de São Paulo, São Paulo.

BECEGATO, J. L. 2007. Impacto ambiental antrópico na APA (Área de Proteção Ambiental) da Ilha Comprida (SP), da pré-história à atualidade. Dissertação. Guarulhos: Universidade Guarulhos, 105p.

BERBEL, G.B.B. Estudo do fósforo sedimentar e de suas especiações químicas em dois sistemas costeiros e Plataforma Continental Sudeste (Brasil) e Baía do Almirantado (Região Antártica) considerando suas relações biogeoquímicas. 2008. 283 p. Tese (Doutorado) - Instituto Oceanográfico, Universidade de São Paulo, São Paulo.

BERBEL, G.B.B.; FAVARO, D.I.T. \& BRAGA, E.S. 2015. Impact of harbour, industry and sewage on the phosphorus geochemistry of a subtropical estuary in Braszil. Marine Pollution Bulletin, 93: 44-52.

BIANCHI, T. S. 2007. Biogeochemistry of Estuaries. Oxford University Press, Oxford. 706p. 
BOUDOU, J. 2001. Em favor da Talassografia. GEOGRAFARES, Vitória, n 2. p. $71-80$.

BRAGA, E.S. Nutrientes dissolvidos e produção primária do fitoplâncton em dois sistemas costeiros do estado de São Paulo. 1995. 2v. Tese (Doutorado) - Instituto Oceanográfico, Universidade de São Paulo, São Paulo.

BRAGA, E.S.; BONETTI, C.V.D.H.; BURONEL, L. \& BONETTI-FILHO, J. 2000. Eutrophication and bacterial pollution caused by industrial and domestic wastes at the Baixada Santista Estuarine System - Brazil. Marine Pollution Bulletin. V.40, n.2, p.165-173.

BRAGA, E.S.; ESCHRIQUE, S.A.; BASTOS, A.T.C.C. \& COELHO, L.H. 2009. Silicato dissolvido e seu papel traçador de aportes terrestres/sedimentares em sistemas estuarinos. Anais do Congresso Brasileiro de Geoquímica, Ouro Preto - MG.

CARACO, N.F.; COLE, J.J.; LiNKENS, G.E. 1993. Sulfate control of phosphorus availability in lakes. Hydrobiologia 252, 275-280.

CETESB. Companhia Ambiental do Estado de São Paulo. Qualidade das águas superficiais no estado de São Paulo. 2015. Disponível em: http://aguasinteriores.cetesb.sp.gov.br. Acesso em 10 de Abril de 2016.

CIIAGRO. 2016. Centro Integrado de Informações Agrometeorológicas. Monitoramento Climático. Disponível: http://www.ciiagro.sp.gov.br. Acesso em 10/02/2016.

COELHO, L.V. Estudo biogeoquímico do fósforo no complexo estuarinolagunar de Cananéia-Iguape (SP): influência do Valo Grande e fluxo bêntico. 2011. 142p. Dissertação (Mestrado) - Instituto Oceanográfico, Universidade de São Paulo. São Paulo-SP.

CRUZ Jr, F.W.; BURNS, S.J.; JERCINOVIC, M.; KARMANN, I.; SHARP, W.D.; VUILLE, M. 2007. Evidence of rainfall variations in Southern Brazil from trace element ratios $(\mathrm{Mg} / \mathrm{Ca}$ and $\mathrm{Sr} / \mathrm{Ca})$ in a Late Pleistocene stalagmite. Geochemica et Cosmochica Acta. 71:2250-2263. 
DAEE. 1989. Departamento de Águas e Energia Elétrica. Controle de erosão: bases conceituais e técnicas; diretrizes para o planejamento urbano e regional; orientações para o controle de voçorocas urbanas. São Paulo: DAEE/IPT. 92 p.

DAS CHAGAS, J.V.R. Análise da deformabilidade do fosfogesso. 2014. 130p. Dissertação (Mestrado) - Escola de Engenharia Civil, Universidade Federal de Goiás, Goiânia.

ESCHRIQUE, S.A. 2011. Estudo do balanço biogeoquímico dos nutrientes dissolvidos principais como indicador da influência antrópica em sistemas estuarinos do nordeste e sudeste do Brasil. 2011. 229p. Tese (Doutorado) - Instituto Oceanográfico, Universidade de São Paulo, São Paulo.

FITZSIMONS, M.F.; LOHAN, M.F.; TAPPIN, A.D.; MILLWARD, G.E. 2011.The Role of Suspended Particles. Estuarine and Coastal Biogeochemistry. Treatise on Estuarine and Coastal Science, p. 71-114.

FREITAS, R.C.; BARCELOS, R.L.; PISETTA, M.; RODRIGUES, M.; FURTADO, V.V. 2006. O Canal do Valo Grande e o assoreamento no sistema estuarino-lagunar de Cananeia-Iguape, Estado de São Paulo, Brasil. Anais Simpósio Brasileiro de Oceanografia: Oceanografia e Mudanças Globais,3.

FROELICH, P.N. 1988. Kinetic control of dissolved phosphate in natural rivers and estuaries: A primer on the phosphate buffer mechanism. Limnol. And Oceanogr., v.33, p. 649-668.

GEOBRÁS. 1996. Complexo Valo grande-Mar Pequeno-Rio Ribeira de Iguape. Relatório para o serviço do Valo do Ribeira-DAEE, São Paulo, 2 vols.

GIANNINI, P.C.F.; GUEDES, C.C.F.: ÂNGULO, R.LJ.: ASSINE, M.L.; SOUZA, M.C.; MORI, E.K. 2003. Geometria de cordões litorâneos e espaço de acomodação sedimentar da Ilha Comprida, litoral sul paulista: modelo baseado em aerofotointerpretação. In: Congresso da Associação Brasileira de Estudos do Quaternário (Abequa), 9, Recife, PE. 
GIANNINI, P.C.F.; GUEDES, C.C.F.; NASCIMENTO JR., D. R.; TANAKA, A.P.B.; ÂNGULO, R.J.; ASSINE, M.L.; SOUZA, M.C. 2009. Sedimentology and morphologic evolution of the llha Comprida Barrier System, southern São Paulo coast. In: DILLENBURG, S.R.; HESP, P. (Eds.). Geology of the Brazilian coastal barriers: Lecture Notes in the Earth Sciences. New York: SpreingerVerlag.

GRASSHOFF, K. Determination of oxygen. 1983. In: GRASSHOFF, K.; KREMLING, K.; EHRHARDT, M. Methods of Seawater Analysis. 2nd ed. Weinheim: Verlag Chemie, $419 \mathrm{p}$.

GUEDES, C.C.F. Evolução sedimentar Quaternária da Ilha Comprida, Estado de São Paulo. 2009.133p. Dissertação (Mestrado) - Instituto de Geociências, Universidade de São Paulo, São Paulo.

GUO, L.; CAI, Y.; BELIZE, C.; MACDONALD, R.W. 2012. Sources and export fluxes of inorganic and organic carbon and nutrient species from seasonally icecovered Yukon River. Biogeochemistry 107, 187-206.

HOWARTH, R.W.; JENSEN, H.S.; MARINO, R.; POSTMA, H. 1995. Transport and processing of $P$ in near chore and oceanic waters. Phosphorus in the Global Invironment. Wiley, SCOPE, UNEP, p. 323-345.

HUERTA-DIAZ, M.A.; TOVAZ-SÁNCHEZ, A.; FILLIPELLI, G.; LATIMER, J.; SAÑUDO-WILHELMY, S.A. 2005. A combined CDB-MAGIC method for the determination of phosphorus associated with sedimentar iron-oxihydroxides. Applied Geochemistry. v.20, p.2108-2115.

IBGE. 2011. Atlas Geográfico das Zonas Costerias e Oceânicas do Brasil, IBGE, Diretoria de Geociências, Rio de Janeiro. 176p.

INGRAM, R. L. 1971. Sieve Analysis. Procedures in Sedimentary Petrology. Wiley Interscience. p. 9-69.

INMETRO. 2010. Orientações sobre validação de métodos de ensaios químicos. Disponível: http://www.inmetro.gov.br. Acesso em 19/04/2016. 
ITALIANI, D.M.; ALVES, D.P.V.; FIGUEIRA, R.C.L.; DIAS, J.M.A.; MAHIQUES, M.M. 2010. Evolução da linha de costa e morfologia atual do delta do Valo Grande, litoral sudoeste do Brasil. Antropicosta Iberoamerica.

JENSEN, H.S.; BENDIXEN, T.; ANDERSEN, F.O. 2006. Transformation of particle-bound phosphorus at the land-sea interface in a Danish estuary. Water, Air and Soil Pollution: Focus, v.6, p. 547-555.

LARSSONEUR, C.; BOUYSSE, P.; AUFRET, J. P. 1982. The Superficial Sediments of the English Channel and its Western Approach. Sedimentology, 29 (6): p. 851-864.

LIBES, S. M. 2009. Introduction to marine biogeochemistry. 2nd ed. Academic Press. 909p.

LIN, P.; CHEN, M.; GUO, L. 2012. Speciation and transformation of phosphorus and its mixing behavior in the Gulf of Mexico. Geochemica et Cosmochemica Acta. 87, p. 283-298.

LIN, P.; GUO, L.; CHEN, M.; CAI, Y. 2013. Distribution, partitioning and mixing behavior of phosphorus species in the Jiulong River estuary. Marine Chemistry 157, p. 93-105.

MAHIQUES, M.M.; BURONE, L.; FIGUEIRA, R.C.L.; LAVANÉRE-WANDERLY, A.A. de O.; CAPELLARI, B.; ROGACHESKI, C.E.; BARROSO, C.P.; SANTOS, L.A.S.; CORDERO, L.M.; CUSSIOLI, M.C. 2009. Antrophogenic influences in a lagoonal environment: a multiproxy approach at the Valo Grande mouth, Cananeia-Iguape system (SE Brazil) Brazilian Journal Of Oceanography, v.57,n.4,p. 325-337.

MALUF, J.C.C. Estudos dos metais traço (zinco, cádmio e chumbo) em duas regiões do complexo estuarino-lagunar Cananéia-Iguape (SP) sob diferentes pressões antrópicas. 2009. 140p. Dissertação de Mestrado Instituto Oceanográfico, Universidade de São Paulo, São Paulo. 
MARTIN, L; SUGUIO, K. 1978. Ilha Comprida: um exemplo de ilhabarreira ligada às flutuações do nível marinho durante o Quaternário. Congresso Brasileiro de Geologia, 30, 1978. Anais, Recife, SBG, v.2, p. 905-912.

MCDOWELL, D. M.; O'CONNOR, B. A. 1977. Hydraulic Behaviour of Estuaries. Manchester: The Macmillan Press Ltd.

MENG, J.; YU, Z.; YAO, Q.; BIANCHI, T. S.; PAYTAN, A.; ZHAO, B.; PAN, H.; YAO, P. 2014. Distribution, mixing behavior, and transformation of dissolved inorganic phosphorus and suspended particulate phosphorus along a salinity gradient in the Changjiang Estuary. Marine Chemistry, 154. p.11.

MEYBECK, M. 1982. Carbon, nitrogen and phosphorous transport by world Rivers. Amer. J. Sci. v. 282,p. 401-450.

MIRANDA, L.B. de, CASTRO, B.M. de; KJERFVE, B. 2012. Princípios de Oceanografia Física de Estuários. São Paulo: Editora da Universidade de São Paulo, 2 ed.

MIYAO, S.Y.; NISHIHARA, L.; SARTI, C.C. 1986. Características físicas e químicas do sistema estuarino-lagunar de Cananeia-Iguape. Boletim do Instituto Oceanográfico. v.34, p.23-36.

NASCIMENTO Jr, D.R.; GIANNINI, P.C.F.; TANAKA, A.P.B.; GUEDES, C.C.F. 2008. Mudanças morfológicas da extremidade NE da llha Comprida (SP) nos últimos dois séculos. In: Revista do Instituto de Geociências-USP, São Paulo, v.8, n.1, p.25-39.

OLIVEIRA, E.N. Estudo da pesca artesanal em dois setores do complexo estuarino-lagunar de Cananéia-Iguape (SP) considerando relações sócioambientais. 2011. 86p. Dissertação (Mestrado) - Instituto Oceanográfico, Universidade de São Paulo. São Paulo-SP.

PAGLIOSA, P.R.; FONSECA, A.; BOSQUILHA, G.E.; BRAGA, E.S.; BARBOSA. F.A.R. 2005. Phosphorus dynamics in water and sediments in urbanized and non-urbanized rivers in Southern Brazil. Marine Pollution Bulletin. v.50, p.965-974. 
PAULA FILHO, F.J.; de MOURA, M.C.S.; MARINS, R.V. 2012. Fracionamento geoquímico do fósforo em água e sedimentos do Rio Corrente, Bacia hidrográfica do Parnaíba/PI. Revista Virtual de Química, 4(6), p. 623-640.

PISETTA, M. Análise do processo de distribuição do material particulado em suspensão e metais associados no sistema Cananeia-Iguape (SP). 2010. 175p. Tese (Doutorado) - Instituto Oceanográfico, Universidade de São Paulo, São Paulo.

PRASTKA, K., SANDERS, R., JICKELLS, T., 1998. Has the role of estuaries as sources or sinks of dissolved inorganic phosphorus changed over time? Results of a Kd study. Marine Pollution Bulletin. v.36, p.718-728.

RAGUENEAU, O.; CONLEY, D. J.; LEYNAERT, A.; LONGPHUIRT, S.N.; SLOMP, C.P. 2006. Role of diatoms in silicon cycling and coastal marine food webs. In: The silicon cycle: human perturbations and impacts on aquatic systems. Ittekkot, V.; Unger, D.; Humborg, C.; Tac An, N. (eds). SCOPE report series. Island Press. p. 163-195.

RUTTENBERG, K. C. 1992. Development of a sequential extraction method for different forms of phosphorus in marine sediments. Limnology and Oceangography. 37 (7). p. 1460-1482.

RUTTENBERG, K.C. 2005. The Global Phosphorus Cycle. Biogeochemistry First Edition. Treatise of Geochemistry. Vol. 8. p.700.

SANTANA, C. L. Geomorfologia da planície fluvial do Rio Ribeira de Iguape entre Sete Barras e Eldorado (SP): Subsídios ao planejamento físicoterritorial de áreas inundáveis. 2008. 297p. Dissertação (Mestrado em Geografia) - Faculdade de Filosofia, Letras e Ciências Humanas, Universidade de São Paulo, São Paulo.

SARAIVA, E.S.B.G. Nitrogênio e fósforo totais dissolvidos e suas frações inorgânicas e orgânicas: Considerações sobre a metodologia aplicada e estudo de caso em dois sistemas estuarinos do estado de São Paulo. 2003. Tese (Livre-docência). Instituto Oceanográfico, Universidade de São Paulo, São Paulo. 
SARMIENTO, J. L.; GRUBER, N., 2006. Ocean biogeochemical dynamics. Princeton University Press. 503p.

SILVA, J.F. 1989. Dados Climatológicos de Cananéia e Ubatuba (Estado de São Paulo). Boletim Climatológico, São Paulo, n.6, p. 1-21.

SMITH, S.V.; GATTUSO, J.P. 2009. Coral reefs. In: Laffoley D.; Grimsditch G. (Eds.).The management of natural coastal carbon sinks, Gland, Switzerland: IUCN, p. 39-45.

SOUSA, P.H.G. de O. Vulnerabilidade à erosão costeira no litoral de São Paulo: interação entre processos costeiros e atividades antrópicas. 2013. 170p. Tese (Doutorado) - Instituto Oceanográfico, Universidade de São Paulo, São Paulo.

SPIVAKOV, B.Y.; MARIJUTINA, T.A.; MUNTAU,H. 1999. Phosphorus speciation in water and sediments. International Union of Pure and Applied Chemistry (IUPAC), 71 (11), p.2161-2176.

STRICKLAND, J.D.H.; PARSONS, T. R. 1968. A practical handbook of seawater analyses. Ottawa: Fisheries Research Board of Canada. 311p. (Bulletin: Fisheries Research Board of Canada, n167).

SUGUIO, K. 1973. Introdução à sedimentologia. Ed. Edgard Blucher, Edusp, São Paulo. 317p.

TELEGINSKI. A. 1982. Aspectos históricos e fundiários do Vale do Ribeira e sua influência no desenvolvimento econômico da região. In: Simpósio de Ecossistemas da Costa Brasileira III Serra Negra, v.1, p. 104-106.

TELES, A.P.S.S. A evolução geológica Quaternária e a influência do Valo Grande na dinâmica sedimentar de Iguape, São Paulo. 1997. 98p. Dissertação (Mestrado) - Instituto Oceanográfico, Universidade de São Paulo.

TESSLER, M. G.; FURTADO, V.V. 1993. Dinâmica de sedimentação de assoreamento da região lagunar Cananeia-Iguape, Estado de São Paulo. Boletim do Instituto Oceanográfico, São Paulo. v.32, n.2, p.117-124. 
TRÉGUER, P.; NELSON, D.M.; VAN BENNEKOM, A.J.; De MASTER, D.J.; LEYNAERT, A.; QUEGUINER, B. 1995. The silica balance in the world ocean: a reestimate. Science. v. 268. p. 375-379.

TURNER, A.; MILLWARD, G.E. 2002. Suspended particles: Their role in estuarine biogeochemical cycles. Estuarine Coast. Shelf Sci. 55, p. 857-883.

UNESCO. 2005. Word Network of Biosphere Reserves. p.19

VINK , S.; CHAMBERS, R. M \& SMITH, S. V. 1997. Distribution of phosphorus from Tomales Bay, California. Marine Geology, 139, p.157-179. 
ANEXO 1

Tabela de Correlação de Pearson com todos os parâmetros amostrados no Rio Guaraú, Rio Ribeira de Iguape, sistema estuarino-lagunar de CananeiaIguape, Barras de Cananeia e Icapara (SP), agosto de 2014 ( $n=48)$. Em vermelho estão marcadas as correlações estatisticamente significativas $(p<0,05)$.

\begin{tabular}{|c|c|c|c|c|c|c|c|c|c|c|c|c|c|c|c|c|c|c|c|c|c|c|c|c|c|c|}
\hline \multirow{2}{*}{\begin{tabular}{|l} 
Temp. \\
\end{tabular}} & Temp. & \begin{tabular}{|l|} 
Salin. \\
\end{tabular} & $\mathrm{OD}$ & $\mathrm{pH}$ & \begin{tabular}{|l|} 
Turb. \\
\end{tabular} & $\mathrm{Si}$ & $\mathrm{PID}$ & POD & PTD & MPS & MPOS & MPOS $\%$ & $\mathrm{Cl}-\mathrm{a}$ & $\mathrm{PIP}$ & POP & PTP & \begin{tabular}{|l|} 
P-bio \\
\end{tabular} & $\mathrm{P}-\mathrm{Fe}$ & P-CFAP & \begin{tabular}{|l|} 
P-FAP \\
\end{tabular} & \begin{tabular}{|l|} 
P-org \\
\end{tabular} & P-T & $\mathrm{MO} \%$ & $\mathrm{Ca} \%$ & Areia \% & Silte $\%$ \\
\hline & & & & & & & & & & & & & & & & & & & & & & & & & & \\
\hline Salin. & $-0,560$ & & & & & & & & & & & & & & & & & & & & & & & & & \\
\hline OD & 0,450 & $-0,452$ & & & & & & & & & & & & & & & & & & & & & & & & \\
\hline $\mathrm{pH}$ & $-0,850$ & 0,906 & $-0,565$ & & & & & & & & & & & & & & & & & & & & & & & \\
\hline Turb. & $-0,523$ & $-0,451$ & 0,268 & 0,481 & & & & & & & & & & & & & & & & & & & & & & \\
\hline $\mathrm{Si}$ & 0,394 & $\mid-0,958$ & 0,453 & $-0,734$ & 0,455 & & & & & & & & & & & & & & & & & & & & & \\
\hline PID & 0,458 & $-0,810$ & 0,290 & $-0,776$ & 0,139 & 0,822 & & & & & & & & & & & & & & & & & & & & \\
\hline POD & $-0,352$ & $-0,244$ & 0,170 & 0,300 & 0,251 & 0,344 & 0,092 & & & & & & & & & & & & & & & & & & & \\
\hline PTD & 0,410 & $-0,825$ & 0,305 & $-0,678$ & \begin{tabular}{|l|}
0,171 \\
\end{tabular} & 0,848 & 0,993 & 0,213 & & & & & & & & & & & & & & & & & & \\
\hline MPS & $-0,758$ & 0,366 & $-0,262$ & \begin{tabular}{|l|l|}
0,710 \\
\end{tabular} & 0,551 & $-0,372$ & $-0,492$ & $-0,091$ & $-0,494$ & & & & & & & & & & & & & & & & & \\
\hline MPOS & $-0,779$ & 0,602 & $-0,627$ & 0,708 & 0,193 & $-0,565$ & $-0,573$ & $-0,181$ & $-0,584$ & 0,853 & & & & & & & & & & & & & & & & \\
\hline MPOS \% & 0,321 & \begin{tabular}{|l|l|}
0,174 \\
\end{tabular} & $-0,497$ & $\mid-0,157$ & - $-0,457$ & \begin{tabular}{|c|c|}
$-0,073$ \\
\end{tabular} & 0,147 & $-0,141$ & 0,127 & $-0,364$ & 0,116 & & & & & & & & & & & & & & & \\
\hline $\mathrm{Cl}-\mathrm{a}$ & $-0,337$ & $-0,435$ & \begin{tabular}{|l|l|}
0,270 \\
\end{tabular} & $-0,316$ & 0,951 & 0,410 & 0,148 & 0,004 & 0,146 & 0,542 & 0,178 & $-0,486$ & & & & & & & & & & & & & & \\
\hline PIP & 0,302 & -0,813 & 0,541 & $-0,443$ & 0,503 & 0,802 & 0,727 & 0,052 & 0,725 & $-0,119$ & $-0,373$ & $-0,229$ & 0,560 & & & & & & & & & & & & & \\
\hline POP & 0,369 & \begin{tabular}{|l|}
$-0,741$ \\
\end{tabular} & 0,486 & $-0,882$ & 0,118 & 0,784 & 0,771 & 0,351 & 0,805 & $-0,535$ & $-0,606$ & 0,191 & 0,034 & 0,587 & & & & & & & & & & & & \\
\hline PTP & 0,404 & $\mid-0,853$ & 0,542 & -0,803 & 0,319 & \begin{tabular}{|c|}
0,879 \\
\end{tabular} & 0,839 & 0,268 & 0,862 & $-0,425$ & 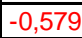 & 0,041 & 0,252 & 0,822 & 0,944 & & & & & & & & & & & \\
\hline P-bio & $-0,439$ & 0,340 & $-0,526$ & \begin{tabular}{|l|l|}
0,545 \\
\end{tabular} & 0,356 & $-0,297$ & $-0,283$ & $-0,106$ & $-0,290$ & 0,188 & 0,314 & 0,199 & $-0,025$ & $-0,258$ & $-0,366$ & $\mid-0,363$ & & & & & & & & & & \\
\hline $\mathrm{P}-\mathrm{Fe}$ & 0,135 & -0,497 & 0,050 & -0,654 & \begin{tabular}{|l|}
0,186 \\
\end{tabular} & 0,522 & 0,400 & $-0,062$ & 0,384 & $-0,146$ & $-0,145$ & 0,233 & 0,144 & 0,187 & 0,155 & 0,185 & \begin{tabular}{|l|}
$-0,028$ \\
\end{tabular} & & & & & & & & & \\
\hline P-CFAP & 0,016 & $-0,140$ & $-0,158$ & 0,179 & 0,433 & 0,211 & 0,206 & 0,101 & 0,215 & 0,007 & 0,003 & 0,173 & 0,171 & 0,195 & 0,116 & 0,161 & \begin{tabular}{|l|l|}
0,683 \\
\end{tabular} & 0,204 & & & & & & & & \\
\hline P-FAP & 0,010 & $-0,580$ & 0,336 & 0,077 & 0,492 & 0,627 & 0,480 & 0,349 & 0,514 & $-0,083$ & $-0,276$ & $-0,113$ & 0,356 & 0,440 & 0,348 & 0,424 & $-0,035$ & 0,512 & 0,625 & & & & & & & \\
\hline P-org & $-0,012$ & $-0,191$ & 0,072 & 0,615 & $-0,023$ & 0,192 & 0,087 & $-0,193$ & 0,062 & $-0,134$ & $-0,100$ & 0,146 & $-0,082$ & $-0,036$ & $-0,075$ & \begin{tabular}{|c|}
$-0,068$ \\
\end{tabular} & $-0,004$ & 0,685 & $-0,032$ & \begin{tabular}{|l|}
0,165 \\
\end{tabular} & & & & & & \\
\hline $\mathrm{P}-\mathrm{T}$ & 0,019 & $-0,284$ & 0,068 & $-0,213$ & 0,040 & 0,292 & 0,175 & $-0,165$ & 0,151 & $-0,143$ & \begin{tabular}{|l|l|}
$-0,117$ \\
\end{tabular} & 0,178 & $-0,023$ & 0,022 & $-0,022$ & $-0,007$ & 0,010 & 0,813 & \begin{tabular}{|l|}
0,056 \\
\end{tabular} & \begin{tabular}{|l|}
0,285 \\
\end{tabular} & \begin{tabular}{|l|}
0,981 \\
\end{tabular} & & & & & \\
\hline $\mathrm{MO} \%$ & $-0,338$ & \begin{tabular}{|l|l|}
0,383 \\
\end{tabular} & $-0,049$ & \begin{tabular}{|l|l|}
0,781 \\
\end{tabular} & \begin{tabular}{|l|}
$-0,257$ \\
\end{tabular} & $-0,346$ & $-0,224$ & 0,028 & $-0,216$ & $-0,057$ & $-0,089$ & $-0,202$ & $-0,291$ & $-0,380$ & $-0,333$ & $-0,389$ & \begin{tabular}{|l|l|}
$-0,014$ \\
\end{tabular} & $-0,271$ & $\mid-0,156$ & \begin{tabular}{|l|}
$-0,139$ \\
\end{tabular} & $-0,057$ & $-0,117$ & & & & \\
\hline $\mathrm{Ca} \%$ & $-0,390$ & 0,382 & $-0,147$ & 0,773 & $-0,235$ & 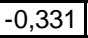 & $-0,181$ & 0,101 & $-0,166$ & 0,048 & 0,055 & $-0,140$ & $-0,317$ & $-0,426$ & $-0,370$ & $-0,434$ & 0,046 & $-0,210$ & $\mid-0,061$ & \begin{tabular}{|l|}
$-0,040$ \\
\end{tabular} & \begin{tabular}{|l|}
0,003 \\
\end{tabular} & $-0,049$ & 0,937 & & & \\
\hline Areia \% & 0,159 & $-0,244$ & $-0,212$ & -0,906 & 0,042 & 0,223 & 0,148 & 0,243 & 0,175 & $-0,067$ & 0,026 & 0,239 & 0,048 & 0,297 & 0,452 & 0,439 & \begin{tabular}{|l|}
$-0,077$ \\
\end{tabular} & 0,102 & \begin{tabular}{|l|}
$-0,047$ \\
\end{tabular} & \begin{tabular}{|l|}
$-0,103$ \\
\end{tabular} & $|-0,261|$ & $-0,190$ & $-0,619$ & $-0,689$ & & \\
\hline Silte \% & $-0,094$ & 0,380 & 0,099 & 0,763 & $-0,157$ & $-0,392$ & $-0,469$ & $-0,167$ & $-0,481$ & 0,123 & 0,122 & $-0,178$ & $-0,123$ & $-0,385$ & $-0,648$ & $-0,613$ & 0,175 & $-0,152$ & 0,034 & \begin{tabular}{|l|}
0,027 \\
\end{tabular} & 0,154 & 0,091 & 0,415 & 0,482 & $-0,724$ & \\
\hline Argila \% & $-0,245$ & $-0,557$ & 0,059 & $-0,911$ & 0,807 & 0,582 & 0,292 & 0,885 & 0,410 & $-0,120$ & $-0,187$ & $-0,166$ & 0,433 & 0,383 & 0,257 & 0,308 & $-0,360$ & 0,056 & \begin{tabular}{|l|}
$-0,271$ \\
\end{tabular} & \begin{tabular}{|l|}
0,305 \\
\end{tabular} & $-0,409$ & $-0,236$ & 0,270 & 0,444 & \begin{tabular}{|l|}
0,013 \\
\end{tabular} & 0,660 \\
\hline
\end{tabular}


ANEXO 2

Tabela de Correlação de Pearson com todos os parâmetros amostrados no Rio Guaraú, Rio Ribeira de lguape, sistema estuarino-lagunar de CananeiaIguape, Barras de Cananeia e Icapara (SP), maio de $2015(n=31)$. Em vermelho estão marcadas as correlações estatisticamente significativas $(p<0,05)$.

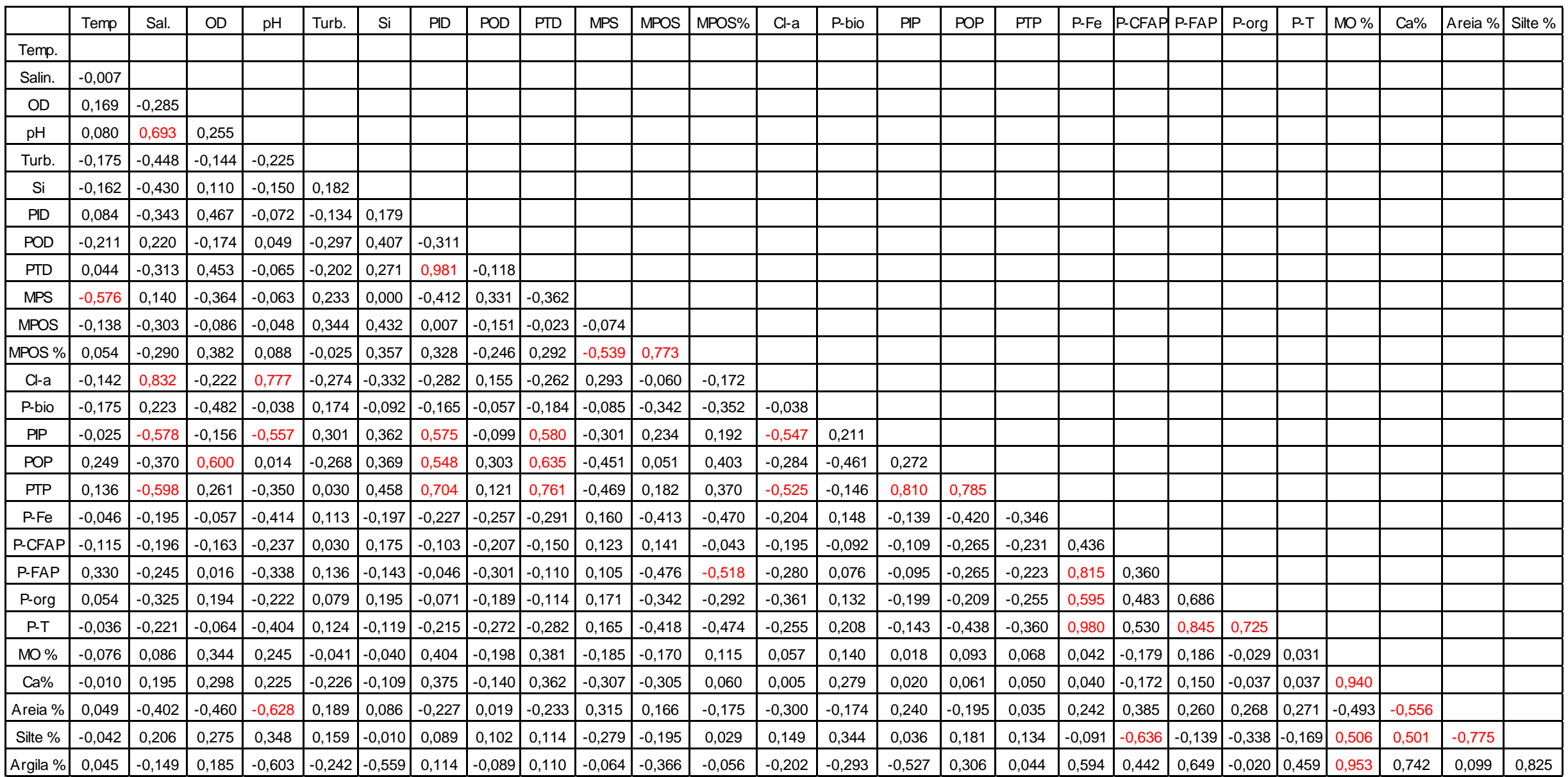

